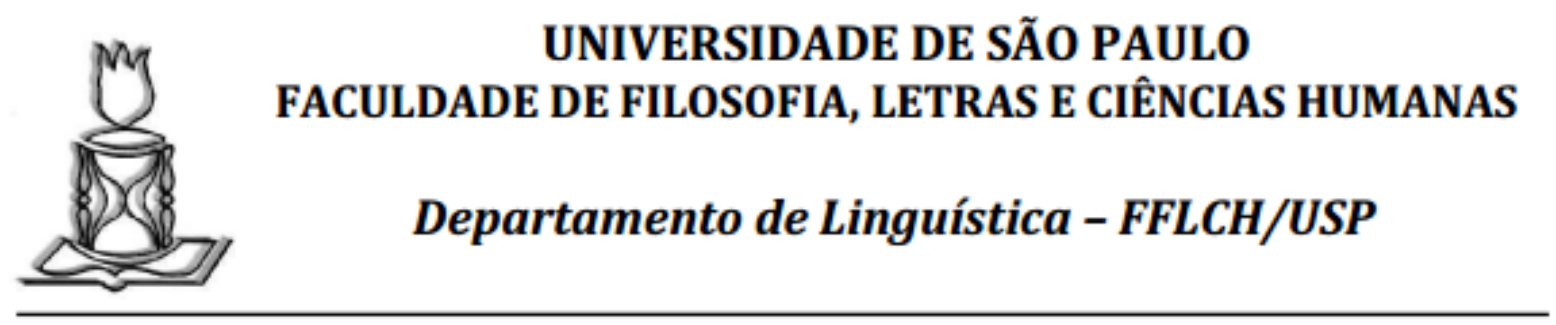

Renata Lúcia Moreira

\title{
Um Olhar da Semiótica para os Discursos em Libras: \\ Descrição do Tempo
}

São Paulo

2016 
UNIVERSIDADE DE SÃO PAULO

FACULDADE DE FILOSOFIA, LETRAS E CIÊNCIAS HUMANAS

DEPARTAMENTO DE LINGUÍSTICA

PROGRAMA DE PÓS-GRADUAÇÃO EM SEMIÓTICA E LINGUÍSTICA GERAL

Renata Lúcia Moreira

reka@usp.br

\section{Um Olhar da Semiótica para os Discursos em Libras: \\ Descrição do Tempo}

São Paulo

2016 
UNIVERSIDADE DE SÃO PAULO

FACULDADE DE FILOSOFIA, LETRAS E CIÊNCIAS HUMANAS

DEPARTAMENTO DE LINGUÍSTICA

PROGRAMA DE PÓS-GRADUAÇÃO EM SEMIÓTICA E LINGUÍSTICA GERAL

\title{
Um Olhar da Semiótica para os Discursos em Libras: Descrição do Tempo
}

\author{
Renata Lúcia Moreira \\ reka@usp.br
}

Tese apresentada ao Programa de Pós-Graduação em Semiótica e Linguística Geral do Departamento de Linguística da Faculdade de Filosofia, Letras e Ciências Humanas da Universidade de São Paulo, para a obtenção do título de Doutor em Letras.

Orientadora: Profa. Dra. Diana Luz Pessoa de Barros

Co-Orientadora: Profa. Dra. Evani de Carvalho Viotti

São Paulo

2016 
Autorizo a reprodução e divulgação total ou parcial deste trabalho, por qualquer meio convencional ou eletrônico, para fins de estudo e pesquisa, desde que citada a fonte.

Catalogação na Publicação

Serviço de Biblioteca e Documentação

Faculdade de Filosofia, Letras e Ciências Humanas da Universidade de São Paulo

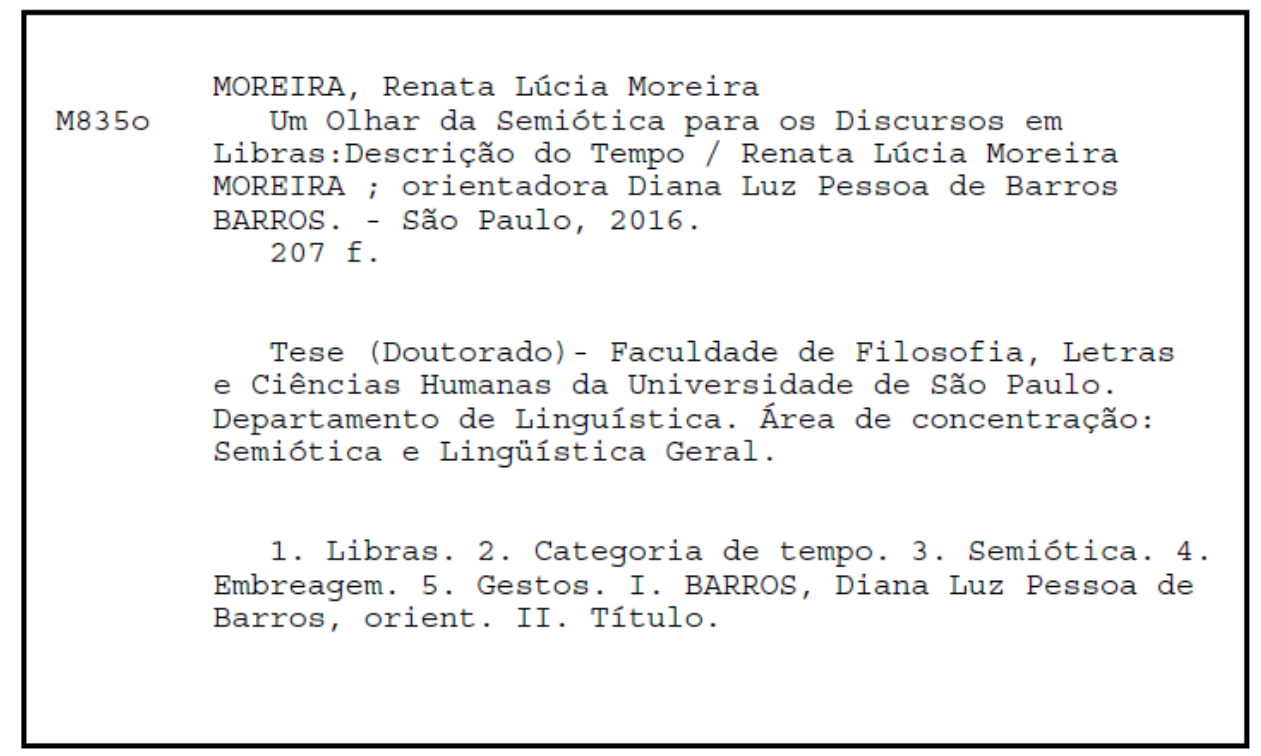


Nome: MOREIRA, Renata Lúcia

Título: Um olhar da semiótica para os discursos em libras: descrição do tempo

Tese apresentada ao Programa de Pós-Graduação em Semiótica e Linguística Geral do Departamento de Linguística da Faculdade de Filosofia, Letras e Ciências Humanas da Universidade de São Paulo, para a obtenção do título de Doutor em Letras.

Área de concentração: Semiótica e Linguística Geral

Aprovada em ___ _ _ 2016.

\section{Banca Examinadora:}

Profa. Dra. Diana Luz Pessoa de Barros

Universidade de São Paulo (USP)

Profa. Dra. Evani de Carvalho Viotti

Universidade de São Paulo (USP)

Prof. Dr. José Luiz Fiorin

Universidade de São Paulo (USP)

Profa. Dra. Elizabeth Harkot-de-La-Taille

Universidade de São Paulo (USP)

Profa. Dra. Lucia Teixeira de Siqueira e Oliveira

Universidade Federal Fluminense (UFF)

Prof. Dr. André Nogueira Xavier

Universidade Federal do Paraná (UFPR) 
Á minha avó Maria Thereza, uma grande escritora, a quem a tempa sá trouxe mais vida e sabedaria. 


\section{Agradecimentos}

Um estudo sobre o tempo não poderia ter outro obstáculo senão o próprio tempo. Foram muitos anos de doutorado, muitos momentos de dúvida, de temores de todos os tipos, dificuldades e percalços, mas também de muitas lições de vida e superação. Algumas vezes, o tempo parecia não passar e tudo se tornava fluído, um pouco perdido; outras vezes, era preciso correr atrás dele e tentar recuperá-lo a qualquer custo. Quantas vezes a vontade não foi de multiplicá-lo ou até mesmo de pará-lo, para conseguir chegar até aqui. Implacável, o tempo foi além de um mero objeto de pesquisa, mas um amigo da aluna inquieta, que não queria acabar, e, ao mesmo tempo, seu maior inimigo nessa luta consigo mesma. O que não queria ter fim, no entanto, ganhou seu ponto final. E isso só foi possível porque, em cada instante deste trabalho, cada uma das pessoas que citarei a seguir me apoiou, incentivou e ajudou a percorrer esse caminho acadêmico e escrever cada linha desta tese.

Agradeço imensamente e com muito carinho minha orientadora, Diana Luz Pessoa de Barros, por ter me recebido de braços abertos na semiótica, em um momento de transição e muitas mudanças; por tudo que me ensinou nos últimos anos; pelas horas de conversas e correções do meu texto; pela dedicação, paciência e entusiasmo com que conduziu a nossa pesquisa; pela confiança que teve em nosso trabalho desde o início; por ter me dado liberdade de caminhar do meu jeito, mas também por me chamar para bem perto dela e me guiar, quando foi necessário; por ter me ajudado a olhar para o trabalho com mais coragem e assertividade; por ter compreendido minhas aflições e ter conseguido me resgatar a tempo.

Com o mesmo carinho, tenho muito a agradecer a minha co-orientadora, Evani Viotti, que foi quem me ensinou a fazer pesquisa, quando tudo isso começou, na iniciação científica. Foi ela que me apresentou ao mundo dos Surdos e das línguas de sinais, durante o mestrado, e sempre me surpreendeu com suas novas ideias, novas empreitadas no mundo da Linguística. Agradeço a Evani, por toda força, atenção, e ajuda que me deu ao longo de todos esses anos; pela compreensão em todos os momentos difíceis; por sempre acreditar em mim; por tudo que aprendo com ela, nas discussões em grupo, em suas aulas, em nossas conversas.

Sinto-me realmente muito privilegiada e honrada por ser orientada por duas pessoas e duas pesquisadoras como a Diana e a Evani. Nada do que eu diga aqui será suficiente para expressar toda minha gratidão, orgulho e a admiração por elas. 
Aos professores que fizeram parte da banca do exame de qualificação, José Luiz Fiorin e Elizabeth Harjot de La Taille, por todas as valiosas contribuições para o desenvolvimento deste trabalho. Faço um agradecimento muito especial ao professor Fiorin, que foi o responsável por todo encantamento que tenho pela semiótica. A influência de suas aulas e de seu trabalho nesta tese é enorme. Minha admiração por ele me fez querer continuar a estudar a enunciação em libras e a desvendar as "astúcias" do tempo nessa língua.

A todos os meus professores da graduação e da pós, que, de alguma forma, aparecem nas linhas a seguir, pois, cada um deles, a seu modo, me marcou e contribuiu com a minha formação como linguista. Em especial, agradeço ao professor Ivã Lopes, pelo exemplo de dedicação à pesquisa e ao grupo, que mantém viva a semiótica na USP. Agradeço a confiança que depositou em mim desde o primeiro instante em que comecei a frequentar o GES-USP. Ao Waldir, pelo entusiasmo por aquilo que desafia a teoria semiótica, e à Norma Discini, que foi a primeira a apontar o jeito interessante de os surdos marcarem o tempo em seu discurso. Agradeço, ainda, quatro professores que foram fundamentais nesse caminho até aqui. À professora Esmeralda V. Negrão, por ter sido um exemplo de pesquisadora para mim, desde a época de Elementos de Linguística, e sempre uma interlocutora atenciosa nos eventos dos quais participamos. Ao professor Leland McCleary, por todas as contribuições que deu à minha pesquisa, direta ou indiretamente, e por me fazer pensar em sempre algo novo e desafiador sobre as línguas de um modo geral. Ao professor Marcos Lopes, o eterno mestre, a quem precisei ouvir muitas vezes, para poder me ouvir um pouco mais! E ao professor Sherman Wilcox, da Universidade do Novo México, que, mesmo de longe, me incentiva e vibra por mim.

Aos colaboradores surdos e ouvintes, sem os quais não seria possível e nem haveria por que realizar esta pesquisa. Agradeço aos surdos Celso Badin, Regiane Agrella e Rimar Segala, e à ouvinte, intérprete e professora Neiva de Aquino Albres, que contaram as histórias que foram analisadas nesta tese. Agradeço, também, aos intérpretes de libras, Alexandre Guimarães e Thyago Santos, e aos ouvintes e amigos, André Xavier, Ana Seelaender e Thaís Bolgueroni, pela participação na formação do corpus deste trabalho por suas impressões sobre a construção do tempo em libras.

Agradeço o Departamento de Linguística (DL) da Universidade de São Paulo (USP) e a agência de fomento CNPq (Conselho Nacional de Desenvolvimento Científico e Tecnológico), por terem me concedido uma bolsa de estudo para desenvolver meu trabalho. Aproveito, para agradecer, com muito carinho, os funcionários do DL, Érica de Lima e Robson D. Viera, por todo auxílio ao longo desses anos. 
Aos tradutores do resumo desta tese, Glaucia Fernandes (inglês) e Guillaume Delsart (francês). Agradeço, também, a ajuda grandiosa do professor Ivã Lopes e das amigas Milca Leão e Taís de Oliveira, nos ajustes teóricos dessas traduções. Um agradecimento especial para Eunice Moreira, pela revisão de toda a tese.

A todos do grupo GES-USP, do qual tenho muito orgulho de fazer parte. Fui muito bem recebida pelos semioticistas laboriosos e aprendi muito com todas as interações das tardes de sexta-feira. Em especial, agradeço a amizade sincera e constante de Daniel Leite, Guilherme W. R., Eliane Domaneschi, Marcos Rogério Costa, Carlos Vinicius Veneziani, Marina Maluli, Thiago Correa, Lucas Shimoda, Alpha Simonetti, Dulce Nunes e Aylin Martinez. Agradeço, com muito carinho, às amigas, Taís de Oliveira, Eliane Soares e Paula Martins, pela companhia em muitas horas conflituosas, pelas conversas e pelas risadas gostosas, nos eventos, dentro e fora da faculdade. Também sou muito grata ao apoio que recebi, em momentos bem tensos, de Mariana Luz Pessoa de Barros e Carolina Lemos, amigas de velhos tempos, desde os encontros dos Clássicos da Linguística.

Aos colegas do Grupo LLIC, ao qual sempre me sentirei ligada, por todas as discussões teóricas e, também, momentos de descontração. Em especial, agradeço aos colegas João Paulo da Silva, Rodrigo Madrid, Juliana Angel, Cecília Farias, Cacilda Lima, e aos mais antigos, como Tarcísio Leite, Clarissa Mariano, Ana Seelaender, Fernanda Canever e Joana Franco. Em especial, destaco a amizade construída com a convivência nesse grupo, e nada situada ou restrita a ele, de Thaís Bolgueroni (Konrad e Pedrinho) e Juliana Nasser (Wu e Vinicius).

Às colegas queridos que conheci na academia e que, de algum modo, fazem parte do meu trajeto científico, fora e dentro da área de língua de sinas, Aline da Cruz, Cristiane Silva, Eneida Leal, Maria Carolina Casati, Vânia Santiago, Vinicius Nascimento, Julio Barbosa, Lívia Oushiro, Bruna Polachini, Fernando Sirota e Sylvia Lia Neves. Cada um, a seu modo, teve uma participação importante no decorrer dos meus estudos, na escrita desta tese, nas discussões sobre língua e educação, nem sempre tão acadêmicas, mas que rondaram a pesquisa e algumas escolhas da vida. Aos amigos que surgiram pela estrada através dos anos e ultrapassaram os muros da universidade, também marcando minha trajetória neste doutorado, como Laura Fortes, Dona Lola, Clara, Carlos B., Mariângela, Pedro Luís, André M. e Renato Luz.

Aos amigos de escola, Adriana, Lilia, Rosana, Patrícia, Sandra, Ricardo, Kishi e Paulo, que trouxeram mais luz e alegria à minha vida e são exemplos para mim da arte de ensinar. Em especial, à Juliana Bloch, que foi sensível a todas as minhas oscilações e contradições neste período de doutorado e esteve ao meu lado sempre que precisei. Aos colegas, funcionários e aos 
meus alunos da primeira série do Ensino Médio Noturno do Colégio São Luís, que tornaram mais agradável, mais leve e possível a conciliação entre a escola e a pesquisa. À minha terapeuta Beatriz Viana, que me mostrou como encarar a "montanha". Ela soube ser firme como psicóloga e, ao mesmo tempo, muito amiga, nos instantes em que a tese se escondia dentro de mim.

Aos amigos de todas as horas, estudo ou não, que me ouviram, que me acalmaram, me apoiar nos momentos de angústia. A Milca, cuja serenidade e sensatez sempre me trazem equilíbrio. À Andrea Iguma, pela generosidade de sempre, nas conversas, na companhia, na troca de experiência de vida. Agradeço a ela por todo apoio que me deu no final da pesquisa e por toda ajuda técnica com os videoclipes dos exemplos desta tese. Ao André Xavier, um amigo de longa data, um grande interlocutor dentro e fora da linguística, companheiro de conversas sobre tudo e mais um pouco, com quem sempre aprendo algo novo. Aos amigos de vida inteira, Priscila, Ana Cláudia e Rodrigo, sem os quais minha história seria diferente. Agradeço a confiança que eles sempre depositaram em mim e os laços fortes que nos unem nesta existência.

À Julieta, minha gata com personalidade, porque, apesar de reclamar bastante, soube dividir com esta tese a minha atenção e ser meu elo constante com a realidade nesse período.

A minha família, grande incentivadora deste doutorado, e que soube compreender minha ausência, meus momentos de aflição, e que me deu força, suporte para continuar. A vibração, a torcida, o amor de todos foi fundamental em cada etapa vencida. Agradeço a minha mãe, Eunice, meu pai, Lúcio, meus irmãos, Patrícia e Fernando, e meu cunhado, Leandro, sem os quais nada disto teria sentido. Um agradecimento especial a minha avó Maria Thereza e a minha tia-avó Lela, que nunca deixaram de acreditara na conclusão deste trabalho.

A todas as outras pessoas que eventualmente não tenha mencionado, por um imperdoável lapso de memória, mas que também fizeram parte dessa longa caminhada. Meus mais sinceros agradecimentos a todos! 
"Eu vejo o futuro repetir o passado $E u$ vejo um museu de grandes novidades

O tempo não para”

O Tempo Não Para

Cazuza 


\section{Resumo}

MOREIRA, R. L. Um olhar da semiótica para os discursos em libras: descrição do tempo. 207 f. Tese (Doutorado) - Faculdade de Filosofia, Letras e Ciências Humanas, Universidade de São Paulo (USP), São Paulo, 2016.

O objetivo desta tese é descrever a temporalização em língua de sinais brasileira (libras), no âmbito da teoria semiótica de linha francesa. Para tanto, a proposta é analisar seis textos narrativos sinalizados por surdos ou intérpretes fluentes na língua. Os estudos sobre as línguas de sinais, como os de Liddell (2003), de Finau (2004), de Johnston \& Schembri (2007), de Sinte (2013), têm apontado que as línguas sinalizadas contam com os mecanismos gerais de enunciação; que não há marcas morfológicas de flexão de tempo em seus verbos, e que há outros elementos gramaticais e discursivos envolvidos na construção das relações temporais no interior de seus textos, como gestos manuais (os itens lexicais dicionarizados que têm função de

advérbio, como HOJE, ONTEM, AMANHÃ, etc.), e como outros gestos não manuais, como movimentos do tronco, localização das mãos e direção do olhar do sinalizador. Esta tese vai tratar de mostrar a especificidade da organização do tempo no plano do conteúdo dos textos em libras. $\mathrm{O}$ estudo parte das pesquisas mencionadas e toma como base para a análise o trabalho realizado por Fiorin (2002) no português, para apresentar uma descrição dos mecanismos de instauração e organização do sistema temporal de cada um dos textos selecionados, mostrando como foram marcados o MR (momento de referência) e os diferentes momentos que compõem essas histórias. A proposta foi levantar todas as formas como a libras expressa o presente, o passado e o futuro em seus discursos, descrevendo, assim, o que Greimas \& Courtés (2012) denominam como sendo a localização temporal em um texto e os efeitos de sentido da instauração do tempo. Os dados analisados foram transcritos no software ELAN (EUDICO Language Annotator), seguindo a proposta de McCleary, Viotti \& Leite (2010). As análises feitas mostram que, em alguns textos do corpus, a marcação do tempo é feita por itens lexicais de tempo dicionarizados, por meio de debreagens enunciativas e enuncivas, e, em outros casos, quando não há uma marca temporal específica, a língua conta com outro mecanismo discursivo, uma embreagem heterocategórica, que permite que, por meio de uma neutralização das categorias da enunciação (pessoa, espaço, tempo), o tempo seja construído espacialmente e entendido a partir de elementos que tipicamente instauram pessoa e criam diferentes espaços nos textos.

Palavras-chave: libras; categoria de tempo; semiótica; embreagem; gestos. 


\begin{abstract}
MOREIRA, R. L. A semiotic view of speeches in Libras: A description of time. 207 pp. Thesis (PhD) - Faculty of Philosophy, Letters and Human Sciences, University of São Paulo (USP), São Paulo, Brazil, 2016.

The objective of this thesis is to describe the timing in Brazilian sign language - Libras - within the framework of French Semiotics. As such, the proposal is to analyze six narrative texts signaled by deaf people or fluent interpreters of the language. Studies of sign languages, such as those of Liddell (2003), Finau (2004), Johnston \& Schembri (2007), and Sinte (2013), have pointed out that sign languages use the general mechanisms of enunciation, that there are no morphological markers of tense inflection of verbs in these languages, and that there are other grammatical and discursive elements involved in the construction of temporal relationships within signed texts, such as hand gestures (lexical items listed in dictionaries as adverbs, such as TODAY, YESTERDAY, TOMORROW, etc.) and other non-manual gestures, such as upperbody movements, hand positions, and the direction of the signer's gaze. This thesis intends to demonstrate the specificity of the organization of time in the content of the texts in Libras. The present study takes the aforementioned studies as a starting point and uses the work of Fiorin (2002) about Portuguese Language as a basis for the analysis to present a description of the mechanisms for establishing and organizing the temporal system of each of the texts selected, showing how the MR (moment of reference) and the different moments that make up these stories were marked. The proposal was to survey all the forms by which Libras expresses the present, past and future in its discourses, thus describing what Greimas \& Courtés (2012) call the temporal localization in a text and the effects of meaning in terms of establishing time. The analyzed data were transcribed in the ELAN (EUDICO Language Annotator) software following the proposal of McCleary, Viotti \& Leite (2010). The analyses performed showed that in some texts of the corpus the marking of time is effected by dictionarized temporal lexical items, by means of enunciative and enuncive débrayages (shifting out), and, in other cases where there is no specific temporal marker, the language uses another discursive mechanism-heterocategorical embrayage (shifting in) - which uses a neutralization of enunciation categories (person, space, time) to allow time to be constructed spatially and understood based on elements that typically establish the person and create different spaces in the texts.
\end{abstract}

Keywords: Libras; time category; semiotics; embrayage; gestures. 


\section{Résumé}

MOREIRA, R. L. Un regard sémiotique sur les discours en « libras » (langue des signes brésilienne) : description du temps. $207 \mathrm{f}$. Thèse (doctorat) - Faculté de Philosophie, Lettres et Sciences Humaines, Université de São Paulo (USP), São Paulo, 2016.

L'objectif de cette thèse est de décrire la temporalisation dans la langue des signes brésilienne (Libras), à la lumière de la théorie sémiotique de tradition française. Pour ce faire, notre propos est d'analyser six textes narratifs gestualisés par des personnes sourdes/malentendantes ou des interprètes parlant couramment la langue. Les études sur les langues des signes, comme celles de Liddell (2003) de Finau (2004), Johnston \& Schembri (2007), de Sinte (2013), indiquent que les langues des signes possèdent bien les mécanismes généraux d'énonciation; qu'il n'y a pas de marques morphologiques de flexion du temps dans les verbes de ces langues ; enfin, qu'il y a d'autres éléments grammaticaux et discursifs impliqués dans la construction des relations temporelles à l'intérieur des textes gestualisés : par exemple, les gestes manuels (les éléments lexicaux dictionnarisés à fonction adverbiale, tels que AUJOURD'HUI, HIER, DEMAIN, etc.), et d'autres gestes non manuels comme les mouvements du tronc, l'emplacement des mains et la direction du regard du signalisateur. La présente thèse s'efforce de montrer la spécificité de l'organisation du temps sur le plan du contenu du texte en «Libras ». Notre étude part des recherches susmentionnées et prend comme base d'analyse le travail de Fiorin (2002) au sujet de la langue portugaise, afin de présenter une description des mécanismes de mise en place et d'organisation du système temporel de chacun des textes sélectionnés, en montrant comment ont été marqués le MR (le moment de repère) et les différents moments qui composent ces histoires. L'objectif a été de relever toutes les formes d'expression du présent, du passé et du futur dans les discours en Libras ; ce faisant, nous souhaitions mieux cerner ce que Greimas \& Courtés (2012) nomment la localisation temporelle dans un texte et les effets de sens de l'instauration du temps. Les données analysées ont été transcrites dans le logiciel ELAN (EUDICO Language Annotator), suivant la proposition de McCleary, Viotti \& Leite (2010). Les analyses effectuées montrent que, dans certains textes du corpus, la marque du temps est faite par des éléments lexicaux de temps dictionnarisés, au moyen de débrayages énonciatifs et énoncifs, tandis que, dans d'autres cas, lorsqu'il n'y a pas de marque temporelle spécifique, la langue dispose d'un autre mécanisme discursif, à savoir, un embrayage hétérocatégorique permettant, grâce à une neutralisation des coordonnées de l'énonciation (personne, espace, temps), que le temps soit construit spatialement et saisi à partir d'éléments destinés, en priorité et de façon typique, à la mise en place des catégories personnelles et spatiales dans les textes.

Mot-clés : langue des signes brésilienne; catégorie du temps; sémiotique; embrayage ; geste. 


\section{Sumário}

$\begin{array}{ll}\text { Introdução } & 17\end{array}$

\section{Capítulo 1}

$\begin{array}{ll}\text { A teoria semiótica e o tempo } & 33\end{array}$

1.1) A teoria semiótica greimasiana e os estudos da enunciação 33

1.2) O nível discursivo e o tempo 36

$\begin{array}{ll}\text { 1.2.1) A sintaxe discursiva } & 39\end{array}$

1.2.1.1) As instâncias enunciativas $\quad 40$

1.3) A categoria de tempo $\quad 41$

1.3.1) O tempo linguístico e discursivo $\quad 42$

1.4) Os mecanismos discursivos de instauração de tempo 47

1.4.1) As debreagens 47

$\begin{array}{ll}\text { 1.4.2) As embreagens } & 50\end{array}$

1.4.2.1) A embreagem heterocategórica $\quad 52$

1.4.3) Os efeitos de sentido das debreagens e embreagens de tempo $\quad 57$

$\begin{array}{ll}\text { 1.5) Considerações finais do capítulo } & 69\end{array}$

\section{Capítulo 2}

$\begin{array}{ll}\text { As línguas de sinais e o tempo } & 70\end{array}$

2.1) O estudos linguísticos sobre as línguas de sinais $\quad 70$

2.2) O estudo sobre o tempo nas línguas de sinais $\quad 76$

$\begin{array}{ll}\text { 2.2.1) Os marcadores e a linha do tempo } & 76\end{array}$

2.3) Outro olhar sobre o tempo nas línguas de sinais $\quad 79$

2.4) Considerações finais do capítulo 90 


\section{Capítulo 3}

$\begin{array}{ll}\text { A metodologia da descrição do tempo em libras } & 91\end{array}$

3.1) O levantamento de dados 91

3.1.1) Levantamento dos itens lexicais dicionarizados 92

3.1.2) Construção do corpus de textos em libras 98

3.1.2.1) "História do Gibi 1" e "História do Gibi 2" 100

3.1.2.2) "O amor é surdo" 103

3.1.2.3) "Minha Vida" 104

$\begin{array}{ll}3.1 .2 .4) \text { "Sonhos" } & 104\end{array}$

3.1.2.5) "Metáfora - O escorpião e a tartaruga" 105

3.2) A transcrição dos dados no ELAN 105

3.3) Proposta de segmentação dos textos 109

$\begin{array}{ll}3.4) & \text { Considerações finais do capítulo } \\ & 122\end{array}$

\section{Capítulo 4}

O tempo em textos em libras

4.1) Descrição e análise do tempo nos textos em libras 123

$\begin{array}{ll}\text { 4.1.1) Os tempos enunciativos } & 129\end{array}$

4.1.1.1) Nível da narração 130

$\begin{array}{ll}\text { 4.1.1.2) Nível do narrado } & 132\end{array}$

4.1.1.3) A simulação da enunciação nas debreagens internas $\quad 136$

4.1.2) Os tempos enuncivos 151

$\begin{array}{ll}\text { 4.1.2.1) Tempo passado } & 151\end{array}$

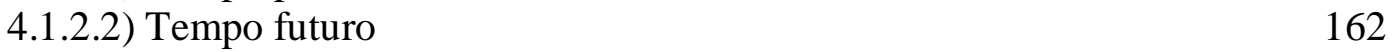

4.2) As embreagens temporais em libras 168

4.2.1) Embreagem heterocategórica e a marcação do tempo em libras $\quad 170$

4.3) Os efeitos de sentido da marcação temporal em libras $\quad 176$

4.4) Considerações finais do capítulo 177

$\begin{array}{lr}\text { Conclusão } & 184\end{array}$

$\begin{array}{lr}\text { Referências bibliográficas } & 190\end{array}$

$\begin{array}{ll}\text { Anexos } & 200\end{array}$

I) Relatório com a transcrição do texto "História do Gibi 1" 201

II) Levantamento dos sinais dicionarizados que indicam tempo 203

III) DVD com os textos, os exemplos da tese e a transcrição no ELAN 206 


\section{Introdução}

"Por seres tão inventivo

E pareceres contínuo

Teтро tempo tempo tempo

És um dos deuses mais lindos

Tempo tempo tempo tempo"

Oração ao Tempo

Caetano Veloso

Desde muito pequenos, construímos diversos tipos de textos: orais, escritos, visuais, gestuais, musicais, etc., para expressar sentimentos, ideias; para contar histórias, reais ou fictícias; para nos comunicar e persuadir nossos destinatários de alguma coisa. Para produzir os diferentes efeitos de sentido que queremos transmitir em nossas interações, os nossos textos precisam ter alguma organização discursiva (sintática e semântica) que envolva a instauração das pessoas, do espaço e do tempo (as categorias da enunciação), que ancora o que é dito na realidade e criam, entre outros efeitos, o de proximidade ou distanciamento entre o destinador e o destinatário de uma mensagem. Os discursos que produzimos envolvem, então, de alguma forma, sempre essas categorias enunciativas, pois sempre há um enunciador, um sujeito que narra e os sujeitos que participam dos eventos que são contados, assim como sempre se pode interpretar o local do acontecimento narrado e do qual se enuncia a história, e o momento em que tudo isso ocorre. A ordem de apresentação temporal e a concatenação de fatos, por exemplo, são fundamentais para que os textos que produzimos se tornem compreensíveis e façam sentido àqueles com quem interagimos. O tempo, portanto, é um dos elementos essenciais na construção de nossos discursos.

Seja como tema ou figura construída textualmente, em tratados filosóficos, em pinturas surrealistas ou em versos poéticos, seja como uma das categorias que estruturam as diferentes enunciações nos discursos humanos, o tempo causa fascínio e desperta a curiosidade dos estudiosos de diferentes áreas do conhecimento, dos artistas, dos homens de um modo geral. Entender como o tempo é sentido por diferentes povos, como ele é codificado linguisticamente por cada comunidade, como ele se torna sujeito de ação ou anti-sujeito, na estrutura narrativa de diferentes textos, move pesquisa, incentiva tratados, inspira a arte. O tempo físico, psíquico ou linguístico sempre estará na agenda científica e entre as angústias humanas diante da efemeridade da vida. 
Há diferentes maneiras de estudar o tempo, dependendo da ciência que se debruça sobre ele e os pressupostos teóricos usados para descrevê-lo. Alguns estudos, principalmente da Sociologia e da Antropologia, se preocupam com a forma como o tempo é conceitualizado ou expresso linguisticamente por cada cultura; outros trabalhos, como esta tese, salientam as características linguísticas e, sobretudo, discursivas do tempo e o analisam como uma categoria enunciativa, responsável pela temporalização dos textos, pela organização do nível mais concreto dos discursos das diferentes línguas naturais e dos mais variados tipos de linguagem.

Dentro da área da Antropologia, uma forma de entender o tempo é associando a sua codificação linguística com a experiência temporal de cada povo. Segundo Hall (1959), ao analisar as maneiras como uma comunidade "fala" do tempo, expressa as suas relações temporais, é possível ver como ela lida com o tempo, como entende o passado, como entende o que é futuro. A noção sobre a passagem do tempo, do que seria um tempo longo ou um tempo curto, também varia entre as diferentes comunidades humanas. $\mathrm{O}$ autor ainda nota que essa relação que os homens estabelecem com o tempo rege suas relações sociais e suas regras, como polidez, suas interações e até a organização da rotina e das tarefas. Hall menciona que hábitos e regras como o horário de ligar para a casa de alguém, o tempo para se responder a um convite, e a ideia do que seja muito ou pouco tempo, gasto ou economia de tempo vai variar de cultura para cultura. Para o autor, a ideia de futuro ou passado próximos e distantes também é algo que tem a ver com a forma como cada povo entende sua história e faz suas prospecções. Nesse sentido, a codificação linguística ou discursiva do tempo é entendida como um meio de expressar a relação do homem com a natureza. Cada língua, portanto, tem seu modo de fazer referência ao tempo, suas formas de nomeá-lo e marcá-lo linguisticamente. As metáforas sobre tempo, por exemplo, presentes em uma língua, podem mostrar a maneira como cada povo entende o que é passado, futuro e presente. Segundo Hall, os americanos pensam no tempo como uma estrada, em que o futuro se encontra no horizonte, à frente, associado ao progresso, e também como algo material, relacionado ao dinheiro, e que pode, assim, ser gasto, economizado, adquirido, etc.; por isso se pode dizer, em inglês, algo como "we can earn time" ou "we waste time".

Sob a perspectiva da Sociologia, Thompson (1991) também analisa como a noção de tempo se altera conforme a cultura e como ela se modificou ao longo dos séculos, principalmente, com a Revolução Industrial. Segundo o autor, essa mudança na forma de experimentar o tempo também transformou os espaços sociais, como a fábrica e a igreja. Seguindo as ideia de Karl Marx, Thompson relaciona essa mudança com a difusão dos relógios e com a moral vigente nesse período de transição para uma era industrial, na Europa. O autor mostra, no início de seu artigo, 
que as sociedades não industriais, por exemplo, viviam e sentiam o dia passar e orientavam suas atividades conforme o tempo da natureza, dos animais, das suas tarefas, sem relógio, sem marcações precisas do tempo. A medição do tempo desses povos se fazia em relação "à duração do ciclo do trabalho e das tarefas domésticas" (p.46), e, portanto, o tempo só existia à medida que as coisas naturalmente aconteciam no dia, ou na vida das pessoas. Para o autor, uma maneira de verificar isso é por meio, por exemplo, da forma como esses homens se referiam linguisticamente ao tempo. Segundo Thompson, em comunidades de camponeses e pescadores, em que havia uma estrutura comercial muito pequena, as notações de tempo também estavam mais relacionadas à necessidade das pessoas, ao ritmo natural das coisas, e das tarefas diárias, e não era, assim, importante marcar hora, contabilizá-la.

Thompson mostra que as transformações no modo de compreender o tempo, na cultura ocidental, podem ser analisadas a partir dessa oposição entre o "tempo natural" e o "tempo do relógio". E apresenta, então, a sua hipótese de que a transição para uma sociedade industrial desenvolvida pode ter exigido uma reorganização dos hábitos pessoais, e que essa mudança na forma pessoal de compreender o tempo e a passagem dele pode ter alterado também a disciplina de trabalho e de produção. É possível pensar, portanto, que as formas de fazer referência ao tempo, de codificá-lo também se alteraram e foram ganhando precisão, foram se estabelecendo como notações mais objetivas, ao longo da História.

Essas reflexões da Antropologia e da Sociologia sobre o tempo nos mostram que, sem dúvida, não foi só a Física que se interessou pelo fenômeno do tempo físico ou cronológico. O tempo encanta as ciências humanas de modo geral e de diferentes maneiras, e é um objeto de investigação também dos estudos linguísticos, em que é visto a partir de perspectivas estruturalistas, formalistas, funcionalistas, cognitivistas, etc., e entendido, dependendo da corrente teórica, como um objeto inerente à linguagem, construído no discurso, e não apenas como um fato do mundo natural, um elemento cultural ${ }^{1}$. A semiótica de linha francesa, desenvolvida por Algirdas Julien Greimas e seguidores, desde os anos 60, que norteará a pesquisa apresentada neste trabalho, é um exemplo de teoria do discurso que se preocupa com as questões da enunciação do tempo.

\footnotetext{
${ }^{1}$ Podemos citar, como exemplos de estudos sobre o tempo em diversas línguas orais, alguns autores que desenvolveram suas pesquisas nessas diferentes áreas da Linguística: Jespersen (1924), Reichenbach (1947), Lyons (1968), Genette (1972), Benveniste (2005 [1976] e 2006 [1976]), Givon (1977 e 1984), Dowty (1982), Comrie (1985), Dahl (1985), Langacker (1987, 1991), Tenuta (1992 e 2006), Chafe (1994), Cutrer (1994), Fiorin (2002 e 2008), Silva (2004), Lin (2006), Barros (2011), etc.
} 
Linguistas e semioticistas de diferentes épocas e abordagens científicas têm defendido a ideia de que todas as línguas apresentam formas de expressar o tempo e reconhecem nessa categoria dêitica um elemento conector central na organização dos diferentes discursos ${ }^{2}$. Muitas teorias linguísticas, como a Gramática Gerativa, a Semântica Formal, a Gramática Cognitiva, entre outras, e a Semiótica Discursiva, por exemplo, debruçaram-se sobre a questão do tempo e deram a ele um caráter estritamente linguístico. As pesquisas têm verificado como os discursos estruturam as relações temporais que tornam seu sentido lógico, que dão cronologia aos fatos narrados ou criam as ilusões de presente, de passado e de futuro. As relações temporais, no entanto, podem se manifestar de diferentes formas, dependendo da língua ou do sistema semiótico em que o discurso é criado ${ }^{3}$. Saber que marcas gramaticais ou discursivas que cada linguagem, verbal ou não verbal, dispõe para instaurar o tempo é um campo enorme de investigação, até porque as formas podem ser muitas, não só pela particularidade de cada plano de expressão dos variados discursos que produzimos, mas também pelo fato de o tempo poder ser criado por diferentes estratégias enunciativas, no plano do conteúdo.

A maneira como o tempo é estruturado no discurso pode criar a ilusão de uma sucessão cronológica dos eventos ou, até mesmo, a de um caos temporal. A organização temporal escolhida pelo enunciador gerará efeitos de sentido que serão fundamentais para o entendimento geral do que foi dito. Toda história que contamos, por exemplo, tem em sua superfície marcas textuais (elementos gramaticais e discursivos) que, de alguma forma, nos ajudam a entender o que veio antes, o que veio depois, e o que aconteceu ao mesmo tempo na narrativa. E o eventual ocultamento dessas marcas também pode ser entendido como uma estratégia discursiva importante para a interpretação do tempo e do texto como um todo. A ausência de formas explícitas não significa ausência de tempo. Há outras pistas, até mesmo dadas pela manifestação das demais categorias discursivas (pessoa e espaço), para entender a organização temporal em um texto. As possíveis marcas e pistas de tempo variam conforme o discurso produzido. A forma de

\footnotetext{
${ }^{2}$ Essa ideia aparece dessa forma em Lyons (1968), Givon (1977 e 1984) e Cutrer (1994).

${ }^{3}$ Muitos autores, de diferentes abordagens teóricas, têm mostrado que, embora o tempo pareça ser uma categoria universal, presente em todas as línguas, a forma de codificação dele varia bastante. Meir \& Sandler (2008: 89), por exemplo, comentam que a divisão entre passado, presente e futuro não é uniforme em todas as línguas, até mesmo entre aquelas em que a marcação temporal é feita pelo sistema verbal. As autoras exemplificam essa variação citando línguas como o inglês, de um lado, e o hebraico ou árabe, do outro. Enquanto, no inglês, distingue-se morfologicamente esses três tempos, como em talk (presente), talked (passado) e will talk (futuro), por exemplo, em árabe, essa distinção morfológica ocorre só entre passado e não-passado (presente e futuro).
} 
manifestar essa categoria do plano do conteúdo, portanto, também vai depender do plano da expressão de cada texto ${ }^{4}$.

Se, quando olhamos para os nossos discursos, percebemos que, para se constituírem como tais, eles precisam necessariamente, entre outros elementos, como pessoa e espaço, da categoria de tempo, também conseguimos perceber que o tempo precisa, por sua vez, do discurso para existir, ou seja, para ser um elemento textual, significativo. Partindo das reflexões do filósofo Santo Agostinho sobre a experiência temporal, Fiorin (2002) mostra que o homem só pode apreender e medir o tempo, quando o semiotiza. Sem a linguagem, o homem pode ter experiências com o tempo, mas isso não terá sentido para ele sem uma forma semiótica, ou seja, se ele não tiver um conteúdo e uma expressão, independentemente do tipo de manifestação que ele possa ter, nos textos de uma língua. Segundo o autor, fora da linguagem, "o passado não é mais, o futuro não é ainda e o presente não é sempre” (p.130). O tempo, portanto, se manifesta "na discursivação das ações, isto é, na narração, que é o simulacro da ação do homem no mundo" (p. 140). A existência de uma codificação de passado, de futuro ou de presente, seja ela qual for (um sintagma, um morfema preso, um morfema livre, um advérbio, uma expressão cristalizada, uma gíria, um gesto, etc.), é que faz com que exista, na língua, o passado, o futuro e o presente. Nesse sentido, o tempo linguístico é, inicialmente, uma criação da linguagem, pois ele se constitui no ato de uma enunciação e não é determinado pelo tempo físico, cronológico (ou até psicológico), pois é ele quem pode codificar todo e qualquer tempo em um discurso, criando o ponto de referência a partir do qual são localizados os eventos narrados. O tempo linguístico, portanto, pode ser entendido como um tempo do discurso, criado e organizado no interior do plano do conteúdo dos diferentes textos que produzimos.

A semiótica greimasiana oferece um aparato teórico-metodológico que nos ajuda a entender a construção dos sentidos dos diferentes discursos, descrevendo cada elemento que compõe toda essa estruturação textual e entendendo como cada um deles se relaciona e contribui com os efeitos de sentidos que são criados nos enunciados. Nessa perspectiva teórica, o tempo é entendido como uma categoria da linguagem e, segundo Fiorin (2002: 142), intrínseco ao ato de narrar. Para a semiótica, o tempo está presente no plano do conteúdo do discurso de todo e qualquer objeto de significação: em um texto verbal, em uma música, em uma coreografia, em

\footnotetext{
${ }^{4}$ Em textos visuais como a pintura, por exemplo, pode-se analisar o tempo, categoria do plano do conteúdo, por meio de elementos pictóricos, como o toque do pincel na tela, os traços de linha, os aspectos cromáticos, que pertencem ao plano da expressão e compõem os enunciados desses discursos (ver Zilberberg, 2015:13). O tipo de linha e cor podem, assim, ser entendidos como uma forma de incorporar a enunciação no enunciado, e, por isso, esses elementos podem ser dêiticos e, entre outras coisas, indicar tempo.
} 
uma representação teatral, em um filme, em uma pintura, em uma história em quadrinhos, em um texto gestual sinalizado, em uma prática, etc. Dentro do percurso gerativo de sentido, o tempo é estudado como parte da semântica e da sintaxe discursivas e considerado uma das categorias da enunciação responsáveis pela passagem das estruturas narrativas ao discurso.

O objetivo desta tese é descrever a temporalização em língua de sinais brasileira (libras), no âmbito da teoria semiótica de linha francesa ${ }^{5}$. Para tanto, a ideia é analisar o plano do conteúdo de seis textos narrativos sinalizados por surdos ou intérpretes fluentes na língua, e verificar, em especial, como se comporta a sintaxe discursiva de cada um deles. O trabalho consiste em uma descrição dos marcadores e dos mecanismos de instauração e estruturação do tempo e seus efeitos de sentido nos textos, ou seja, como são construídos os sistemas enunciativos e enuncivos e, em especial, como é feito o que Greimas \& Courtés (2012) denominam como sendo a localização temporal em um discurso.

Esta tese é decorrência natural da pesquisa de mestrado, que teve como objetivo apresentar uma proposta de descrição da dêixis de pessoa em um texto em libras, no âmbito da teoria de espaços mentais (Fauconnier, 1994, Fauconnier \& Turner, 2002) e da gramática cognitiva (Langacker, 1991) ${ }^{6}$. Partindo da descrição feita por Liddell (2003) para a ASL, mostramos, nesse estudo, que, em libras, a dêixis de pessoa é realizada substancialmente por meio de pronomes (pessoais, possessivos e reflexivos) e dos verbos indicadores ${ }^{7}$.

Os resultados obtidos, nessa pesquisa de mestrado, confirmam a ideia de Liddell de que há uma relação entre a referência de pessoa e a maneira como os surdos utilizam o espaço de sinalização a seu redor. Durante o estudo do texto em libras, foi ficando claro que a dêixis de pessoa depende da maneira como os surdos organizam seu discurso no espaço de sinalização, criam diferentes espaços discursivos e os diferentes tempos na história. Partindo desse estudo

\footnotetext{
${ }^{5}$ Esta pesquisa recebeu o apoio da agência de fomento CNPq - Brasil (Conselho Nacional de Desenvolvimento Científico e Tecnológico) - Processo 157999/2012-2. O trabalho apresentado nesta tese faz parte de um projeto maior do grupo de pesquisa sobre a descrição da libras do ECS (Estudos da Comunidade Surda) e do LLIC (Laboratório de Língua, Interação e Cognição) da Universidade de São Paulo (USP), coordenado pelo Prof. Dr. Leland McCleary (DLM) e pela Profa. Dra. Evani Viotti (DL), que co-orienta este trabalho, e também está relacionado com os estudos desenvolvidos pelo grupo de semiótica do qual também faço parte, o GES-USP (Grupo de Estudos Semióticos da USP), coordenado pelo Prof. Dr. Ivã Carlos Lopes (DL).

${ }^{6}$ A pesquisa de mestrado foi orientada pela Profa. Dra. Evani Viotti (ver Moreira, 2007). O texto analisado na dissertação foi "O amor é surdo", contado pela surda Sylvia Lia Grespan Neve, a quem agradeço imensamente por toda a colaboração na época. Esse texto também foi o estímulo para a história contada pelo surdo Celso Badin, que recebeu o mesmo nome e que será analisada, mais adiante, nesta tese.

${ }^{7}$ Outro estudo a respeito da referenciação de pessoa em libras, dentro do grupo de pesquisa LLIC da USP, é a dissertação de mestrado de Bolgueroni (2013). Nesse estudo, a autora descreve outras maneiras de referência e retomada de personagens de uma história.
} 
anterior sobre a instauração de pessoa, então, a proposta do projeto de doutorado foi, portanto, a de dar início ao estudo da categoria de tempo, desta vez, sob outro viés teórico, e olhar para os textos sinalizados com as lentes de uma teoria de discurso que, há muitos anos, tem se especializado na análise dos mais variados textos, verbais, visuais, gestuais, etc., e que tem uma proposta metodológica que permite entender os mecanismos gerais de construção de sentido, entre os quais, os do aparelho formal de enunciação de uma língua ${ }^{8}$.

A ideia é a de que, independentemente da manifestação textual, o modelo de exame da sintaxe discursiva que subjaz ao objeto que estudamos é o mesmo, ou seja, em todos os textos, visuais, gestuais, ou verbais, orais ou escritos, é possível descrever e analisar a instauração do tempo, seguindo os mesmos princípios e categorias de análise. Isso permite que a Semiótica estude textos diversos, poéticos ou não, verbais ou não, e consiga descrever os mecanismos de enunciação de todos eles. E, nesse sentido, os discursos sinalizados não apresentam qualquer restrição a esse tipo de análise e podem ser estudados por meio do mesmo aparato teórico que vem olhando para as línguas orais desde os anos 60. A diferença da manifestação textual das línguas sinalizadas apenas amplia as discussões em torno dos desafios colocados pelo plano da expressão, mas não é um empecilho ao estudo proposto.

Outra questão que tem interesse para esta introdução é a de que as línguas de sinais nem sempre foram contempladas pelos estudos linguísticos. Na época em que Saussure ministrou seus cursos sobre linguística geral, não havia ainda um reconhecimento científico da natureza linguística das línguas de sinais ${ }^{9}$. Para o autor, as línguas sinalizadas eram um tipo de linguagem como a escrita, e não um sistema de signos convencionais, estruturado, apresentando uma gramática e podendo ser analisado em todos os níveis linguísticos, como qualquer outra língua de modalidade oral.

Essa concepção sobre as línguas de sinais permaneceu ativa por muito tempo entre os linguistas e estudiosos do discurso, que se voltaram apenas para a pesquisa sobre as línguas orais ou sobre outras linguagens, outros sistemas simbólicos, verbais ou não. Isso só mudou quando as línguas sinalizadas foram consideradas línguas naturais com o trabalho de Stokoe (1960), que deu

\footnotetext{
${ }^{8}$ Dar continuidade ao estudo do mestrado, descrevendo a categoria de tempo, foi uma sugestão feita pelo Prof. Dr. José Luiz Fiorin (DL/USP), que observou que, só com uma descrição do tempo e do espaço, saberíamos mais sobre a enunciação em libras.

${ }^{9}$ A menção mais próxima de línguas de sinais feita por Saussure, por exemplo, no Curso de linguística geral, é a expressão "o alfabeto dos surdos-mudos", que o autor usa quando menciona os possíveis tipos de sistemas simbólicos, como a escrita das línguas orais, que não são "língua", mas sim, "linguagens", e que, portanto, não seriam objetos de estudo da Linguística (Saussure, 1995 [1969]: 24).
} 
início à descrição da gramática da língua de sinais americana (ASL - American Sign Language), e, um pouco mais tarde, com o trabalho de Klima \& Bellugi (1979) sobre essa mesma língua.

Desde então, muitos estudos linguísticos sobre as diferentes línguas de sinais surgiram no mundo todo. No Brasil, não foi diferente. Hoje, há muitas pesquisas sobre a fonética, a fonologia, a morfologia, a sintaxe, a semântica, o discurso, a pragmática na língua brasileira de sinais (libras). Segundo Quadros (2012), há trabalhos na sociolinguística, na linguística textual e na análise do discurso, e uma parcela significativa de estudos sobre libras também nas áreas de aquisição de linguagem e psicolinguística (ver Karnopp, 1994; Quadros, 1995 e 1997), mas que, apesar disso, ainda há muito a ser feito ${ }^{10}$. Há, por exemplo, poucos estudos sobre o tempo em $\operatorname{libras}^{11}$.

Além disso, uma boa parte dessas pesquisas iniciais sobre a língua se preocupou em mostrar que ela constitui um sistema em constante evolução, que emerge independente e espontaneamente dentro de comunidades de surdos e que sua aquisição é feita de modo natural como acontece com qualquer outra língua. Essa necessidade de provar o status de língua natural fez com que muitos desses estudos buscassem corroborar certos pressupostos teóricos de uma linguística tradicional e descrever a libras, muitas vezes, a partir de paradigmas já consolidados na descrição e análise das línguas orais, ou até mesmo de outras línguas de sinais mais estudadas em outras partes do mundo.

Sem dúvida que muito do que a ciência linguística e as teorias do discurso já fizeram serve para o estudo das línguas de sinais, mas é preciso muito cuidado para que o conhecimento que se gerou com o estudo das línguas orais não seja transferido diretamente às línguas sinalizadas, ignorando o que elas podem trazer de novo aos estudos linguísticos e do texto. Muitos pesquisadores sobre libras, como Felipe de Souza (1998) e Quadros (1999 e 2004), se

\footnotetext{
${ }^{10}$ Em uma entrevista à revista ReVEL, a Profa. Dra. Ronice Müller Quadros (UFSC) identifica uma primeira fase dos estudos linguísticos sobre a Libras, no Brasil, que se iniciou na década de 80, com os trabalhos de Lucinda Ferreira Brito (1984, 1990, 1995), que, pela primeira vez, descreveu aspectos da gramática de libras, mostrando diferenças entre a variante da libras usada em São Paulo e a língua de sinais Urubu-Kaapor da comunidade indígena UrubuKaapor, no interior de Maranhão. Ronice ainda cita alguns trabalhos que marcam esses primeiros anos de estudos na área, como o de Felipe de Souza (1998), com sua descrição tipológica para os verbos da língua; os de Karnopp (1994, 1999), com seus estudos sobre a fonologia da língua, e os de Quadros (1995, 1997 e 1999), com suas pesquisas sobre aquisição de libras, focadas no nível sintático, como uso dos pronomes, concordância verbal, etc. Segundo a pesquisadora, os estudos sobre a libras no Brasil se intensificaram depois do decreto e regulamentação da Lei de Libras (Lei 10.436/2002 e Decreto 5626/2005) (ver Quadros 2012).

${ }^{11}$ Um desses trabalhos é o de Finau (2004), que faz uma descrição da estrutura temporal dessa língua relacionando-a com a categoria de aspecto. Apresento as ideias dessa pesquisa sobre o tempo no capítulo 2 desta tese. Outro estudo sobre o tempo em libras, no Brasil, é a dissertação de mestrado de Marcelo Wagner de Lima e Souza, defendida em 2013, na Pontifícia Universidade Católica de Minas Gerais, intitulada "O processo de temporoespacialização na construção do espaço enunciativo de narrativas em libras".
} 
valem, por exemplo, da existência de morfemas flexionais na língua, em lugar de propor outra forma de entender o fenômeno que estudam.

Outros trabalhos, mais recentes, sobre as línguas de sinais, como o de Liddell (2003), Dudis (2004, 2007 e 2011), McCleary \& Viotti (2007, 2010, 2011, 2014), Leite (2008), Bolgueroni (2013), Wilcox \& Xavier (2013), Xavier (2014) e Silva (2014) têm procurado olhar para as línguas sinalizadas de outra forma, salientando as suas características visuais e espaciais, e "têm mostrado a relevância de alargar os horizontes da linguística para incluir aquilo que está além do que pode ser descrito de maneira categórica e lógica" (Viotti, 2013: 13) ${ }^{12}$.

Essa discussão, presente na literatura sobre as línguas de sinais, se dá, porque, por muito tempo, os estudos procuraram nessas línguas, apenas as características gramaticais e discursivas que eram parecidas com as das línguas orais, ignorando até mesmo aspectos estruturais delas que são decorrentes de seu modo de expressão. Esta tese, entretanto, não entrará nesse debate, pois, ao tomar a semiótica discursiva como fundamento teórico-metodológico, vai procurar descrever apenas o nível discursivo do plano do conteúdo dos textos em libras.

Além disso, em relação ao plano da expressão gestual, Greimas (1979) já mostra que a passagem de uma linguística limitada ao estudo das línguas naturais para uma semiótica geral representou uma grande revolução científica. O autor argumenta que discussões em torno do conceito de referente, mundo extralinguístico, gestualidade natural e cultural do ser humano parecem ter sido cruciais para que a Semiótica propusesse uma "semiótica do mundo natural" e contemplasse o estudo dos gestos segundos os princípios que a teoria postulava na época ${ }^{13}$. Segundo Greimas, a Semiótica expandiu, assim, o objeto de análise linguística, uma vez que anunciou a possibilidade de se estudar textos não verbais, entendidos, nesse momento, como textos não linguísticos.

\footnotetext{
${ }^{12}$ Os fenômenos estudados por Liddell (2003), na ASL, também vêm sendo estudados em libras. Entre os trabalhos citados por Viotti (2013), há aqueles que descrevem a formação dos sinais, a dêixis e os modos de referenciação de pessoa, tratam das vozes narrativas e estudam a demonstração presente na construção dos textos sinalizados.

${ }^{13}$ Greimas (1979) destaca algumas condições de análise que criam a necessidade de uma semiótica geral, não só de uma semiótica das línguas naturais, uma vez que, para o autor, as teorias existentes em sua época, influenciadas pelo behaviorismo, não davam conta da complexidade do fenômeno da gestualidade: a) a necessidade de um critério comum para a classificação das diversas "substâncias da expressão"; b) a necessidade de posicionar o sistema linguístico em relação às linguagens não verbais; c) a necessidade de contemplar a semiose e, com isso, a relação entre a expressão e o conteúdo.
} 
Basta invertermos esse ponto de vista para nos apercebermos de que a única presença concebível da significação no mundo é a sua manifestação na 'substância' que engloba o homem: o mundo dito sensível torna-se assim, na sua totalidade, o objeto da procura de significação, apresenta-se no seu conjunto e nas suas articulações como uma virtualidade do sentido. A significação pode esconder-se sob todas as aparências sensíveis, está por detrás das imagens, dos cheiros, sabores, sem que por isso esteja nos sons e nas imagens. (GREIMAS, 1979, p. 7)

Com essa expansão de seu objeto de análise dos estudos da linguagem, a Semiótica pode se considerar preparada para estudar também as línguas de sinais, que vão apresentar textos com um plano de expressão próximo àquele que a teoria já vem estudando há algum tempo, quando tomou como objeto os textos visuais. Há, no entanto, poucos estudos sobre os textos dessas línguas sinalizadas ainda. Para isso, é preciso que essa teoria olhe para elas cada vez mais, para desvendar, entre outras coisas, suas estratégias discursivas ${ }^{14}$. Nesse sentido, a Linguística também precisa fazer novamente esse movimento descrito por Greimas (1979) e se voltar para um novo objeto de investigação. Depois de ter se aberto para uma semiótica geral, não se limitando ao estudo das línguas naturais, ela também precisa abrir olhos e mentes para as línguas de sinais e ver no estudo delas um novo percurso de entendimento do que seriam as línguas humanas.

As línguas de sinais, como qualquer outra língua natural, possuem signos que são expressos por um aparelho formal de dêixis e que são capazes de fazer a ligação entre o sistema linguístico e o discurso, criando textos e diferentes contextos de enunciação. Os discursos sinalizados também são estruturados temporalmente, e os fatos por eles narrados também podem estar relacionados e organizados em ordem cronológica, simulando, no texto, uma ordem "natural" dos fatos da vida, do mundo natural, e gerando efeitos de estabilidade, ou em uma organização temporal que subverta essa ordem "natural" dos fatos, criando efeitos de sentido de

\footnotetext{
${ }^{14}$ Não há, ainda, muitos trabalhos sobre libras sendo desenvolvidos na área da semiótica greimasiana. Um exemplo é a dissertação de mestrado de Gleice Lane de Araújo Silva (Universidade Federal do Espírito Santo), que tem o objetivo de analisar a figuratividade nos discursos em libras, identificando sinais icônicos produzidos pelos sujeitos surdos e mostrando a importância da iconicidade presente na língua na construção dos sentidos dos textos sinalizados (ver Silva 2009). Nesse trabalho, a autora não faz uma análise da categoria do tempo, mas comenta, no capítulo 3 de seu texto, uma característica na marcação temporal dessa língua. Silva apresenta o sinal FUTURO como sendo icônico, pois, para ela, "apresenta uma visão prospectiva na sua realização" (p.78), informando que o futuro está em frente ao sinalizador - o sinal é realizado com a configuração da mão em $\mathrm{F}$ e com movimento para frente, diferentemente do sinal para passado, que é realizado com a configuração da mão em $\mathrm{B}$, palma para trás, e movimento para trás do ombro. A indicação desse texto foi feita pelo colega Alexandre Bueno.
} 
instabilidade $^{15}$. Mas essas línguas apresentam maneiras diferentes de manifestar a enunciação e, em especial, o tempo linguístico. O uso das categorias da enunciação, portanto, pode apresentar diferenças, se comparado ao modo como elas são usadas nas línguas orais.

Como já foi dito, diferentemente das línguas orais, as línguas sinalizadas possuem um plano de expressão que não é formado por uma substância sonora, mas sim, visual (os enunciados são produzidos por gestos realizados com as mãos, com o tronco, com a cabeça, e com expressões faciais). Haverá, então, diferenças na programação temporal do texto nessas línguas, uma vez que, nas línguas orais, a expressão do tempo é linear, por causa do som. Em uma língua de sinais, existem outras estratégias, próprias de sua visualidade, para programar o tempo em seus textos. Examinar as programações textual e temporal dos textos das línguas de sinais, assim como compará-las às dos textos das línguas orais, é uma etapa de trabalho importante para a investigação sobre o tempo em libras, mas que ainda não pôde ser contemplada neste estudo, e fica como sugestão para pesquisas futuras sobre o assunto. Como já foi dito, esta tese vai se concentrar na descrição da temporalização, no nível discursivo do plano do conteúdo, em especial, da localização temporal nos textos sinalizados.

Stokoe (1960 e 1979) foi o primeiro a enfatizar que as línguas sinalizadas têm, não apenas um canal de produção de seus significantes diferentes do das línguas orais, mas também outras características gramaticais e discursivas. Para Hockett (1978: 274), essas diferenças na gramática e no discurso das línguas de sinais acontecem, porque essas línguas podem utilizar todas as possibilidades que uma linguagem produzida no espaço apresenta para construir e transmitir seus significados. Essa dimensionalidade espacial sintática complexa possibilita, segundo o autor, uma presença maior de signos icônicos nos textos sinalizados, e uma maior possibilidade de pantomima ou apontamentos durante a sinalização e também uma forma peculiar de instaurar a pessoa, o espaço e o tempo nos discursos ${ }^{16}$.

\footnotetext{
${ }^{15}$ Greimas (1979) define o mundo natural como sendo aquele que já é acessado por nós por meio da linguagem e que, por isso, é constituído por ela. O que vemos e sentimos como sendo o mundo exterior, natural, já é uma semiose. O autor diz que o mundo visível não é uma tela homogênea, mas sim, uma tela constituída por muitas camadas de significantes e que é preciso considerar esse mundo "extralinguístico não como um referente absoluto, mas como o lugar da manifestação do sensível, suscetível de ser a manifestação do sentido humano, isto é, da significação para o homem, e encarar esse referente como um conjunto de sistemas semióticos mais ou menos implícitos" (GREIMAS, 1979, p. 10).

${ }^{16}$ Nas línguas orais, por exemplo, o arranjo das palavras é sempre linear, e a simultaneidade aparece apenas no acento delas e na entonação das frases. Nas línguas de sinais, a linearidade e a simultaneidade podem ocorrer sempre e acontecer concomitantemente (Hockett, 1978: 274).
} 
Estudos sobre várias línguas de sinais do mundo vêm mostrando que, com a ausência de uma marca de flexão de tempo nos verbos dessas línguas, como ocorre, por exemplo, em uma língua oral como o português, a referência temporal é realizada de outras maneiras, por meio de outros elementos gramaticais e discursivos que esse tipo de língua dispõe em seu sistema ${ }^{17}$. Sabe-se que, como muitas línguas orais, as línguas de sinais contam com um léxico próprio de tempo, que consiste em um conjunto de gestos manuais, sempre localizados no mesmo ponto no espaço de sinalização, que são itens lexicais dicionarizados que equivalem aos nossos advérbios temporais (ontem, amanhã, hoje, agora, etc.), ou expressões linguísticas que equivalem às nossas expressões adverbiais (no mês passado, ano que vem, no futuro, etc.). Além disso, os estudos apontam que há outros gestos, não manuais que, quando realizados em determinados locais do espaço de sinalização, seguindo uma linha de tempo, que pode ser projetada na frente, horizontalmente, na diagonal, ou de forma perpendicular ao corpo do sinalizador, podem construir as relações temporais no interior dos textos, como é o caso dos movimentos do corpo, da cabeça e a direção do olhar do sinalizador (ver Friedman, 1975; Amaral, Coutinho \& Martins, 1994; Finau, 2004; Mintz, 2005; Johnston \& Schembri, 2007; Meir \& Sandler, 2008; Sinte, 2013).

A proposta desta tese é justamente a de mostrar a especificidade da organização do tempo no plano do conteúdo dos textos em libras, considerando que todas essas estratégias envolvidas na marcação de tempo em uma língua de sinais não sejam específicas de tempo, mas estejam, de um modo geral, envolvidas com a organização enunciativa dos discursos sinalizados. Este trabalho procura verificar, então, como se marca e organiza o tempo; quais são os mecanismos de debreagem e embreagem que estão envolvidos na instauração temporal nas histórias analisadas, e quais foram os efeitos de sentido que a construção do tempo ajudou a criar nesses discursos. Para tanto, foram levantados e descritos tanto os itens lexicais já dicionarizados que indicam tempo, basicamente sinais produzidos por gestos manuais, como também outros itens gramaticais e discursivos, produzidos por gestos do corpo e do rosto (em especial, do olhar) do sinalizador, que instauram as categorias da enunciação nos textos do corpus desta pesquisa.

\footnotetext{
${ }^{17}$ Segundo Tenuta (1992: 50), nem todas as línguas expressam o tempo por meio da gramaticalização. A referência temporal, muitas vezes, é lexicalizada. Há línguas orais, como o chinês e línguas do oeste da África, por exemplo, que não apresentam flexão verbal de tempo, mas que expressam suas relações temporais por meio de advérbios, pela marcação do aspecto do verbo ou por meio de informações pragmáticas, lexicalizadas, que ajudam a indicar o tempo em que o enunciado está (Lin, 2006; Meir \& Sandler, 2008).
} 
Esta tese tem por preocupação central, portanto, as formas de instauração do tempo nos discursos em libras, sem o objetivo de analisar os textos em libras que corroborem apenas um modelo de descrição de uma determinada teoria, mas sim, a finalidade de descrever uma característica dessa língua (a construção do tempo nos discursos), para poder contribuir com parte da descrição de sua gramática e de seu discurso e, assim, oferecer um melhor entendimento de como uma categoria da enunciação tão fundamental na construção de sentidos dos textos se constitui, se comporta e se relaciona com outras categorias enunciativas. A ideia é que este trabalho possa, não só contribuir com a descrição da gramática e estudo dos discursos em libras, como também possa ajudar, futuramente, com as discussões sobre a metodologia de ensino dela para surdos e ouvintes ${ }^{18}$.

Para realizar a descrição do tempo em libras e levantar as hipóteses de trabalho, observamos, na tese, a língua em uso. Para isso, primeiro, foi preciso construir um corpus e transcrevê-lo. A pesquisa foi desenvolvida a partir da transcrição e análise da "História do Gibi 1", e de trechos de "História do Gibi 2", "O amor é surdo", "Minha Vida" , "Sonhos" e "Metáfora - O escorpião e a tartaruga", contadas por colaboradores surdos e usuários fluentes da libras $^{19}$. Os dados analisados foram transcritos no ELAN (EUDICO Language Annotator), seguindo o modelo de transcrição proposto em McCleary \& Viotti (2007) e McCleary, Viotti \& Leite $(2010)^{20}$. Uma vez realizada uma primeira descrição do tempo nesses textos, foram

\footnotetext{
${ }^{18}$ Os estudos linguísticos, de alguma forma, podem contribuir com essa demanda da área da educação de surdos, uma vez que podem esclarecer aspectos da gramática e do discurso da língua, favorecendo o desenvolvimento de metodologias de ensino de libras melhores tanto para surdos quanto para ouvintes. Leite (2008b: 02-09) menciona que, embora a libras seja hoje vista como uma língua natural dos surdos que ela tenha ganhado espaço nos meios de comunicação, nas instituições de ensino, muitos cursos de libras ainda não estão preparados para lidar com as complexidades linguísticas que a língua apresenta. Para Leite, se não houver um aprofundamento das visões sobre a surdez que valorizem a língua e a identidade surda, será "difícil pensar como uma educação de surdos de qualidade possa ser implementada no Brasil". Para o autor, até propostas como o ensino bilíngue ainda se mostram "aquém das necessidades e anseios da população surda", ainda que seja considerada uma "alternativa mais ética, mas também a mais eficaz no sentido de otimizar o desenvolvimento linguístico, cultural, cognitivo, psicológico e, consequentemente, o potencial escolar" do surdo, ao priorizar a língua de sinais como a sua primeira língua, e o português como a segunda.
}

${ }^{19}$ Há dois textos sinalizados que receberam o nome de "História do Gibi”, por isso o uso da numeração 1 e 2, para identificá-los (e diferenciá-los) nesta tese. O texto de Rimar estudado nesta tese foi sugestão do colega João Paulo da Silva.

${ }^{20}$ O ELAN é o software de transcrição de vídeo e áudio que vem sendo utilizado pelos pesquisadores do grupo ECS e LLIC, para transcrever tanto textos de línguas orais como os de libras. O ELAN pode ser baixado gratuitamente pelo site https://tla.mpi.nl/tools/tla-tools/elan/. O software, o modelo de transcrição e os textos analisados neste trabalho serão apresentados no capítulo 3 desta tese. 
observados outros discursos em libras, como uma aula de história, uma explicação sobre metáforas sinalizadas, etc. ${ }^{21}$.

Para dar um rumo à investigação proposta, elaboramos quatro questões, que nortearam todo o desenvolvimento da pesquisa que apresentamos nos próximos capítulos:

1. Como é que uma língua de sinais estrutura formalmente suas relações temporais? Quais são as estratégias gramaticais e discursivas usadas para marcar e organizar o tempo nos textos em libras?

2. Como são as debreagens temporais de um texto em libras?

2.1. Como se estabelece o sistema enunciativo e o sistema enuncivo de tempo em um texto em libras?

2.1.1. Como são instaurados os Momentos de Referência nos textos?

2.2. Como são estabelecidas as relações temporais internas nos enunciados em libras?

2.2.1. Como são instaurados os Momentos dos Acontecimentos?

2.2.2. Como se estabelece a relação de anterioridade, posterioridade e simultaneidade dentro dos discursos?

2.2.3. Como se estabelece a relação de concomitância ou não dos acontecimentos narrados com o Momento de Referência que foi estabelecido no início do texto?

2.2.4. Quando não há qualquer item lexical que indique tempo realizado numa sinalização, como se sabe, nessa língua, se o evento descrito (seja ele da instância do narrador seja ele da instância dos interlocutores, nas debreagens internas) é narrado no presente, no passado ou no futuro?

3. Como são as embreagens temporais em libras?

3.1. Como se sabe quando um tempo é usado com valor de outro em um texto em libras?

3.2. Quais os tipos de embreagens temporais predominantes nos textos em libras?

4. Quais são os efeitos de sentido criados pelos mecanismos de instauração de tempo nos textos em libras?

\footnotetext{
${ }^{21}$ Alguns dos textos que também fazem parte desta tese são: a "aula de história", "Imaginação", "Dúvida", "Explicação", sinalizados também por Neiva de Aquino Albres, e "Sonho com um carro novo", sinalizado pela surda Regiane Agrella.
} 
Esta tese está organizada em quatro capítulos. No capítulo 1, sintetizamos os pontos teóricos que foram utilizados para analisar os dados deste estudo e fazemos uma discussão a respeito da noção e da estruturação do tempo nos discursos, na perspectiva da teoria semiótica greimasiana. O enfoque, nesta seção, é o trabalho de Fiorin (2002), decorrente das ideias de Benveniste (2005 [1976] e 2006 [1974]). Nesta seção, discorremos brevemente sobre um histórico da teoria da enunciação, no âmbito da Semiótica, e apresentamos alguns conceitos relacionados à enunciação, como as instâncias enunciativas e as categorias de pessoa, tempo e espaço. Destacamos, ainda, o estudo da sintaxe discursiva, do tempo linguístico e dos mecanismos de instauração dessa categoria enunciativa (as debreagens e embreagens) em textos em línguas orais e em textos visuais, poéticos, cancionais e em prosa. Também discutimos, neste capítulo, os efeitos de sentido que são gerados pelos recursos enunciativos empregados nesses discursos.

No capítulo 2, resenhamos alguns trabalhos sobre a categoria de tempo na literatura sobre as línguas de sinais. Destacamos alguns estudos sobre outras línguas sinalizadas do mundo e também sobre libras, que contribuíram com esta pesquisa. Mostramos que os resultados encontrados nessas investigações se aproximam do que verificamos nos textos em libras analisados nesta tese. Por outro lado, também identificamos alguns pontos de discordância entre as abordagens, e discutimos, nesta seção do texto, as diferentes formas de considerar e analisar as marcas de tempo entre os estudiosos dessas línguas.

No capítulo 3, mostramos como a descrição do tempo proposta no projeto foi desenvolvida. Para isso, contamos como foi montado o corpus da pesquisa a partir de um levantamento de sinais já dicionarizados e da observação e estudo de histórias contadas por colaboradores, surdos ou não, fluentes em libras. Em seguida, apresentamos cada um dos textos analisados e o software ELAN utilizado para transcrevê-los. Encerramos este capítulo, propondo uma segmentação para a "História do Gibi 1" e para a "Metáfora - O escorpião e a tartaruga", seguindo a proposta metodológica da semiótica francesa, para mostrar os dois níveis enunciativos que compõem esse texto e que são pertinentes para a análise do tempo: o nível da narração e o nível do narrado.

No capítulo 4, apresentamos a descrição e a análise semiótica do tempo de textos em libras, procurando responder às questões de pesquisa propostas. A ideia, nesta seção, é discutir como o tempo foi instaurado e se organizou no interior dos discursos sinalizados. Para isso, mostramos as debreagens e embreagens temporais realizadas nos textos, e os recursos utilizados por eles para subverter as relações temporais e criar ilusões enunciativas. 
Nas considerações finais deste estudo, sintetizamos os resultados obtidos com o desenvolvimento desta pesquisa.

Além disso, esta tese ainda conta com três anexos: (i) um relatório da transcrição de um dos textos sinalizados analisados até agora, "História do Gibi 1", com a linha da tradução para o português; (ii) um levantamento de sinais dicionarizados que indicam tempo, e (iii) um DVD, com os vídeos com as contações de história estudadas, com os textos em libras ou em português, com os exemplos que ilustraram toda a pesquisa (todas as figuras que representam os textos em libras possuem um videoclipe que pode ser acessado), e com a transcrição dos dados no ELAN. Nesse anexo, também se encontram todas as informações de como acessar os arquivos dessa mídia que acompanha o trabalho. 


\title{
Capítulo 1
}

\section{A teoria semiótica e o tempo}

\begin{abstract}
“(...) a enunciação (...), ao trabalhar a língua, não só a emprega mas também a constitui, num jogo de estabilidades e instabilidades. Ela desestabiliza a lingua e os usos, desfaz diferenças e cria outras, reinventa o universo de sentido, rompe certas coerções sintagmáticas, reconstrói paradigma, faz e desfaz." (Fiorin, 2002: 19)
\end{abstract}

As astúcias da enunciação José Luiz Fiorin

Neste capítulo, o objetivo é descrever resumidamente as bases teóricas sobre as quais este trabalho se constitui, e as ideias que norteiam a forma de enxergar o fenômeno da construção do tempo nos discursos. Primeiramente, é apresentada de forma bastante sucinta a semiótica discursiva francesa e os estudos sobre a enunciação da qual ela se utiliza. Na sequência, discorremos sobre o nível discursivo do percurso gerativo de sentido, em especial, sobre a sintaxe discursiva e sobre a noção de tempo linguístico. Dedicamos uma parte desta seção, ainda, à discussão sobre os mecanismos de instauração de tempo, dando ênfase aos tipos de embreagens que podem acontecer em diferentes textos. Finalizamos o capítulo com uma breve discussão sobre os efeitos de sentidos gerados por esses mecanismos de enunciação.

1.1) A teoria semiótica greimasiana e os estudos da enunciação

Segundo Fiorin (2002: 16-17), tanto o estruturalismo fundado por Saussure como a maior parte de outros modelos linguísticos considerados pós-estruturalistas ou não estruturalistas se preocuparam, e alguns ainda se preocupam, apenas com os objetos discretos e estáveis das línguas $^{22}$. O objetivo dessas teorias era entender os princípios que regem o sistema, a competência linguística. Para elas, o fato de, na língua, haver uma relação entre o que é interno ao sistema com o que é externo a ele, a parole (fala), não era imprescindível para o entendimento

\footnotetext{
${ }^{22}$ Diferentemente de muitas teorias que surgiram após Saussure e que ainda não se preocupam com a fala, as teorias sociolinguísticas, as teorias do discurso, as teorias sobre a conversação, a linguística cognitiva e outras abordagens teóricas que se desenvolveram a partir do estruturalismo europeu ou que dialogam com ele de alguma forma têm colocado como objetivo estudar a língua em uso. No entanto, elas ainda não conseguiram olhar por completo para a fala, sem o viés da língua.
} 
do que é o conhecimento linguístico dos falantes, ou do que é de fato a linguagem humana ${ }^{23}$. As análises se limitavam ao nível da frase e não ousavam chegar ao texto. O estudo da enunciação, por exemplo, era visto como algo além da langue e, portanto, ficou fora do escopo da ciência linguística por muito tempo.

Segundo Barros (2012: 25), os trabalhos sobre o texto e o discurso causaram uma grande mudança nos estudos da linguagem, preenchendo esse vazio que havia nas pesquisas linguísticas antes da metade do século XX. Esses estudos sobre o texto não só ocasionaram o desenvolvimento de uma disciplina (a semiótica, por exemplo) como também permitiram que os linguistas pudessem conhecer melhor, por meio do discurso, a cultura e a sociedade do lugar onde viviam, conhecimento este que os antropólogos, por exemplo, já tinham por meio de seus métodos e trabalhos de campo.

As teorias do texto levantaram um conjunto de regras e princípios de ordem e de organização dos discursos e mostraram, assim, que a instabilidade da parole não é um caos, mas sim, um sistema estruturado. Essas mudanças nos estudos linguísticos remontam a Hjelmslev que, em seu Prolegômenos a uma teoria da linguagem, por exemplo, postula uma teoria linguística com um objeto de estudo mais amplo: o linguista não deveria estudar apenas a língua (o sistema), mas também deveria estudar o discurso (o processo).

Hjelmslev (2003 [1961]) propõe o estudo das instabilidades da língua, mas seguindo o princípio de imanência. Opõe-se, assim, à ideia da transcendência em linguística ${ }^{24}$. Segundo o autor, não existem objetos no mundo que podem ser acessados sem linguagem, mas sim, relações entre objetos criadas pela linguagem e, assim, compreensíveis aos homens. A teoria da língua precisa, então, preocupar-se com as relações, tanto as internas ao sistema como as internas (e externas ao sistema) ao processo, que também é imanente, pois depende da linguagem para existir. $\mathrm{O}$ autor entende essas relações como uma função semiótica (junção de duas grandezas que gera um sentido). Ao estabelecer a função semiótica, Hjelmslev defende que o linguista deve sair do nível da palavra e das sentenças e passar a estudar também o nível discursivo. Para ele, todos os níveis de análise linguísticos devem ser estudados pelos mesmos princípios teóricos e metodológicos. Com essas ideias, Hjelmslev funda uma teoria do discurso e começa a abrir um espaço, na linguística, para o estudo da enunciação.

\footnotetext{
${ }^{23}$ A parole é entendida, por Saussure, como a concretização da langue, ou seja, o uso da língua pelo indivíduo.

${ }^{24}$ Segundo Fiorin (2003: 21), os estudos da linguagem contemporâneos a Hjelmslev eram feitos com o propósito de estudar algo que ia além do fenômeno linguístico. A linguagem era vista sempre como um meio para estudar outros objetos; ela não era vista como um fim em si mesmo.
} 
Segundo Barros (2011: 06), essa mudança no entendimento dos fatos de linguagem levou ao surgimento de teorias que, como a semiótica discursiva de linha francesa fundada por Greimas, nos anos 60, consideram o texto como seu objeto de estudo e como uma unidade de sentido. No início de seus estudos, entretanto, a semiótica, segundo Barros (2012:27), se preocupou mais com as questões no nível narrativo e fundamental do plano do conteúdo do que com a enunciação. Mas, com os desenvolvimentos teóricos constantes e que marcam essa teoria até hoje, os estudos enunciativos tornaram-se parte de seu quadro de investigação e proporcionaram o diálogo da semiótica com a retórica e com a estilística, e o desenvolvimento de estudos da comunicação, da interação e da conversação. Quando a teoria passou a estudar a enunciação, não deixou de priorizar o exame do plano do conteúdo dos textos, imanente, uma vez que a instância enunciativa será entendida como sempre pressuposta pela existência de um discurso, ou seja, também é imanente. Só se acessa a enunciação, portanto, por marcas presentes nos enunciados.

Segundo Benveniste (2006 [1974]), a enunciação é um mecanismo geral, um ato de produzir qualquer enunciado, qualquer texto, não só os linguísticos, mas qualquer expressão de sentido (mímica, música, dança, pintura, etc.). Ela é entendida também, pelo autor, como um ato individual de colocar a língua em funcionamento. Para Benveniste, é muita clara a ideia de que, antes da enunciação, “a língua não é senão a possibilidade da língua” (p.83). E, para ele, é ela que está por trás da instauração das categorias discursivas que tornarão estruturas abstratas e narrativas mais concretas. O autor define a enunciação, então, como a instância do eu, do aqui e do agora, responsável por fazer a passagem entre o sistema (a língua) e o processo (o discurso).

Segundo Benveniste, o homem só se constitui como sujeito quando usa a língua: "é ego quem diz ego". Para o autor, essa capacidade de se tornar sujeito por meio da linguagem é chamada de subjetividade. Segundo Fiorin (2002: 41-42), a categoria de pessoa é fundamental para que uma "linguagem se torne um discurso". Quando um sujeito diz "eu", ele designa a si próprio como um eu e estabelece automaticamente outra pessoa, um $t u$, que pode ser "concreto ou abstrato, presente ou ausente, existente ou inexistente": uma pessoa para quem esse eu vai dizer alguma coisa.

O sujeito que enuncia (o enunciador) determina, além do tu, quem são as não-pessoas da enunciação, ou seja, os não-tus. Como esse sujeito enuncia em um determinado espaço e em um dado tempo, o espaço e o tempo, então, também se organizam a partir desse sujeito. Por isso se diz que a enunciação é o lugar do "ego, hic et nunc" e as línguas humanas são egocêntricas (tudo no discurso é um efeito de sentido criado a partir do ponto de referência do eu). O aqui (hic) é o 
espaço do $e u$, o lugar onde o sujeito produz seus enunciados. E o agora (nunc) é o tempo em que coincidem o momento do evento narrado ou descrito e o ato de enunciação, que é o momento em que o sujeito produz os enunciados. Todo e qualquer texto produzido terá, portanto, relações temporais. Essas relações, no entanto, serão expressas de alguma maneira, marcadas ou não marcadas nos enunciados de forma explícita.

As categorias da enunciação não pertencem apenas às línguas, mas à linguagem como um todo. Todos os textos, verbais ou não, contarão com elas no seu processo de discursivação. Em todos os sistemas semióticos (em todas as linguagens e nas línguas naturais), entretanto, é preciso que haja meios de expressar essas categorias enunciativas, ou seja, é necessário um sistema que organize o processo de produção de um enunciado e marcas de algum tipo, dependendo do plano de expressão, para que o processo ocorra e gere efeitos de sentido. Isso significa dizer que um sistema simbólico só se caracteriza como tal, quando possui formas de expressar as categorias da enunciação, que é o que permite que haja um discurso e, por meio dele, a transmissão de uma mensagem, a construção de um significado. No que diz respeito às questões de enunciação, o que parece diferenciar uma língua natural de outros tipos de linguagem é o fato de os sistemas linguísticos possuírem marcas mais formais, convencionais, simbólicas, que instauram pessoa, espaço e tempo nos enunciados.

Seguindo as ideias de Benveniste e de Hjelmslev, a semiótica de linha francesa, introduzida por Greimas, vê a enunciação como "a instância de mediação, que assegura a discursivização da língua" (Fiorin, 2002: 36). Para essa teoria, a enunciação permite a passagem das estruturas semióticas virtuais e mais simples (nível fundamental e nível narrativo) às estruturas semióticas mais concretas e mais complexas realizadas sob a forma de um discurso (nível discursivo). Ela é vista, então, como uma "instância linguística logicamente pressuposta pela existência do enunciado (que comporta seus traços e suas marcas)”, e o enunciado é visto como o produto de uma enunciação.

\section{2) O nível discursivo e o tempo}

Herdeira das ideias de Saussure e, principalmente de Hjelmslev, a teoria semiótica greimasiana tem se constituído como uma teoria geral que tem como objetivo descrever e explicar "o que o texto diz e como ele faz para dizer o que diz" (Barros, 2011: 07), ou seja, 
examinar que sentidos ele produz e que "procedimentos linguísticos-discursivos" são usados na construção dos diferentes efeitos são gerados pelo discurso (Barros, 2012: 26) ${ }^{25}$.

Greimas entende a construção do sentido de qualquer ato linguístico, ou de qualquer relação simbólica entre forma e conteúdo, como um percurso gerativo. Nos termos de Fiorin (1994:03), o percurso gerativo de sentido é um simulacro metodológico do ato real de produzir os significados em um discurso e é usado para explicar o processo de compreensão, "em que o leitor precisa fazer abstrações a partir da superfície do texto, para poder entendê-lo". Esse simulacro não tem estatuto ontológico. A teoria não afirma que, na produção de um texto, passe-se de um patamar a outro, fazendo complexificações semânticas. E nem que um leitor precisa necessariamente fazer esse percurso para chegar ao entendimento total de um discurso ${ }^{26}$. $\mathrm{O}$ simulacro é metodológico e destinado ao analista que deseja partir de uma proposta geral sobre a estruturação interna de qualquer texto, seja ele verbal ou não, sem deixar de mostrar as diferenças na textualização.

O percurso gerativo de sentido vai do nível mais simples e abstrato (nível fundamental), passa pelo nível das estruturas narrativas e chega ao nível mais complexo e concreto (nível discursivo) do plano do conteúdo de qualquer texto, seja ele verbal ou não verbal. Todos esses níveis possuem uma sintaxe e uma semântica.

O nível discursivo é a primeira etapa de concretização textual. De um ponto de vista semântico, ocorrem, nesse nível, a tematização e a figurativização de um texto. O sujeito da enunciação torna seu texto coerente semanticamente, ao disseminar nele temas e figuras, e gera, assim, diferentes efeitos de sentido.

Nos textos, abaixo, por exemplo, é possível perceber, tanto a estratégia de tematizar, que é formular os valores de forma abstrata, como procedimento da figurativização, que são as figuras, concretas, que recobrem os temas abstratos. No soneto de Camões, "Mudam-se os tempos, mudam-se as vontades"; no quadro de Salvador Dalí, "A Persistência da Memória, e na música de Vinicius de Moraes, “O Relógio”, a seguir, o tempo é tema e figura, no nível discursivo.

\footnotetext{
${ }^{25}$ A teoria semiótica francesa desenvolvida por A. J. Greimas se distingue das teorias semióticas como a desenvolvida nos Estados Unidos, por Charles Peirce, e a da Escola de Tartu, dos formalistas russos. Não serão apresentadas, nesta tese, diferenças entre esses tipos de semióticas e suas formas de análise, embora, reconhecemos que houvesse vantagens também em verificar as questões de tempo sob essas outras perspectivas.

${ }^{26}$ Pesquisas realizadas no âmbito da Teoria Literária, por exemplo, não concebem essa ideia de analisar um texto por meio de um percurso gerativo de sentido.
} 


\section{Mudam-se os tempos, mudam-se as vontades}

Luís de Camões

Mudam-se os tempos, mudam-se as vontades,

Muda-se o ser, muda-se a confiança;

Todo o Mundo é composto de mudança,

Tomando sempre novas qualidades.

Continuamente vemos novidades,

Diferentes em tudo da esperança;

Do mal ficam as mágoas na lembrança,

E do bem, se algum houve, as saudades.

O tempo cobre o chão de verde manto,

Que já coberto foi de neve fria,

E em mim converte em choro o doce canto.

E, afora este mudar-se cada dia,

Outra mudança faz de mor espanto:

Que não se muda já como soía.

(Soneto retirado do livro de Camões, 1998)

\section{A persistência da memória}

Salvador Dali

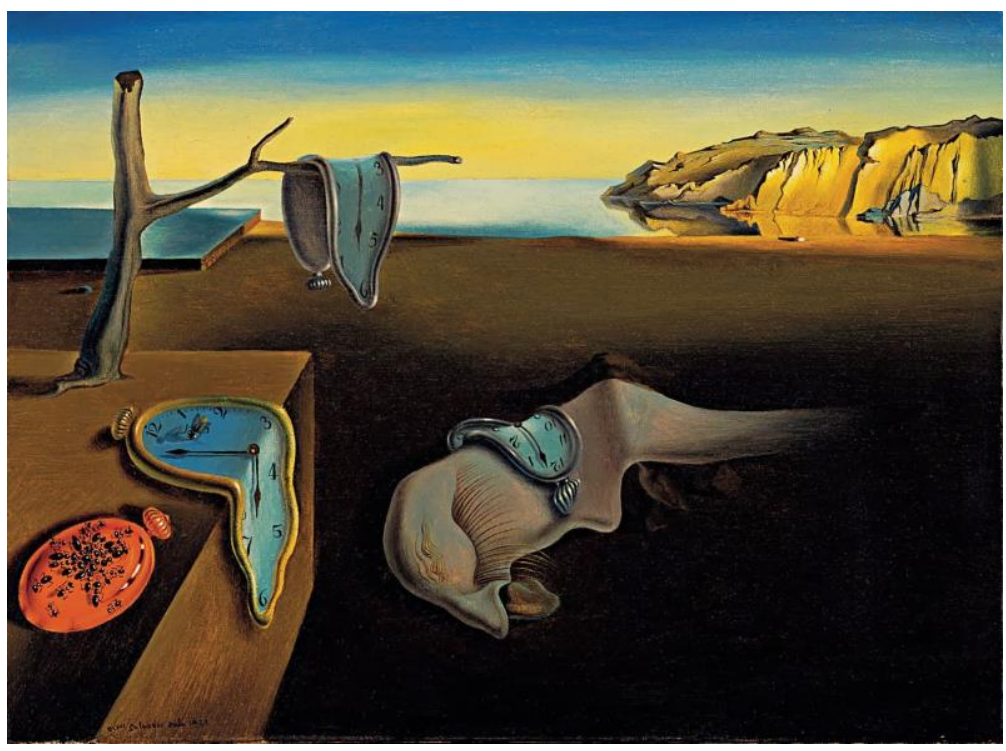

(Disponível em: http://s2.glbimg.com/nOogpONRBt0Yo4q4vhMrfYB9PSE=/298x0/http://s.glbimg.com/po/tt2/bt/53/d/b/98a03f5f012dfe8812313b075c91.png) 


\title{
O Relógio
}

\section{Vinicius de Moraes}

\author{
Passa, tempo, tic-tac \\ Já perdi \\ Tic-tac, passa, hora \\ Toda a alegria \\ Chega logo, tic-tac \\ De fazer \\ Tic-tac, e vai-te embora \\ Meu tic-tac \\ Passa, tempo \\ Dia e noite \\ Bem depressa \\ Noite e dia \\ Não atrasa \\ Tic-tac \\ Não demora \\ Tic-tac \\ Que já estou \\ Tic-tac... \\ Muito cansado \\ (Disponível em: https://www.letras.mus.br/vinicius-de-moraes/87218/)
}

Do ponto de vista sintático, no nível discursivo, projetam-se as categorias da enunciação no enunciado, isto é, ocorrem a actorialização, a espacialização e a temporalização de um texto, e os procedimentos que o enunciador utiliza para persuadir o enunciatário a aceitar seu discurso.

Neste trabalho, como já foi dito, o interesse recai sobre a sintaxe discursiva dos textos em libras selecionados para a pesquisa.

\subsection{1) A sintaxe discursiva}

Uma das formas de estudar a organização dos discursos é compreender como são os mecanismos de instauração da pessoa, do espaço e do tempo da língua em que o texto é produzido. A ideia é que, para entender um discurso, em qualquer língua, é preciso entender como o aparelho formal da enunciação dela se organiza, para expressar ações, narrar eventos, falar do mundo e das coisas.

O sujeito da enunciação transforma a narrativa em discurso, quando instaura pessoa, espaço e tempo em seu texto. A sintaxe discursiva é responsável por explicar, portanto, essas relações entre o enunciado e a enunciação, e enunciador e enunciatário. Nessa etapa do percurso gerativo de sentido, a ideia é estudar as projeções da enunciação e, para isso, é preciso verificar a 
forma como se instaura as categorias enunciativas, e os efeitos de sentido gerados pelas diferentes estratégias enunciativas.

Um enunciado pode conter expressões de pessoa, de espaço ou de tempo, que evidenciam o processo enunciativo, ou seja, pode trazer marcas da enunciação, que remetem à instância de produção. Quando isso ocorre, o ponto de referência eu está projetado no interior do texto. O tempo é estruturado a partir do ponto de referência presente, que é o instante em que o enunciador cria seu discurso, e o espaço projetado no enunciado é o mesmo do lugar onde se encontra quem enuncia. Um enunciado, no entanto, também pode não apresentar elementos enunciativos, mas apenas elementos enuncivos, que não remetem à instância de sua produção e, portanto, ocultam os vestígios da enunciação. O enunciado continuará, então, a pressupor sua instância produtora, mas não terá marcas linguísticas que a revelam, mas sim, marcas que criam, no texto, a ilusão de que não há um eu produtor, por exemplo, o que, entre outros efeitos, distancia o discurso produzido do enunciatário, cria uma verdade mais objetiva. Nesse caso, o ponto de referência eu não está projetado no enunciado; ele só existe no ato de produção. O tempo não é concomitante ao momento da enunciação e, portanto, pode ser localizado de diferentes formas, criando diferentes instantes no texto, e o espaço que aparece não coincide com aquele em que o enunciador está.

\subsubsection{1) As instâncias enunciativas}

Uma questão relacionada à projeção da instância da enunciação no enunciado tem a ver com os diferentes níveis enunciativos que um texto pode apresentar, o que está diretamente ligado à marcação de pessoa. Todo texto (narrativo ou não), em qualquer língua, é formado por muitas vozes discursivas. Além do narrador, percebido quase que de imediato, temos as falas das personagens, transmitidas por esse narrador. Há, ainda, por trás dessas vozes mais concretas, uma voz responsável por tudo que está sendo contado: a voz do enunciador. Essas diferentes vozes presentes em um texto são entendidas, pela teoria semiótica, como pertencentes a pessoas de instâncias ou níveis enunciativos diferentes, que podem, dependendo da situação discursiva, terem um único referente, ou seja, serem sincretizadas de tal maneira que tanto o ator da enunciação (o enunciador) seja também ator do narrado.

Segundo Fiorin (2002: 62-65), existem diferentes níveis de enunciação ou instâncias enunciativas em um mesmo discurso. Esses níveis ficam evidentes quando observamos a delegação de vozes, que ocorre tanto em narrativas literárias escritas, como nas falas do dia a dia. 
Segundo o autor, o primeiro nível da enunciação é o do enunciador e o do enunciatário. O segundo nível é o do narrador e o do narratário, e o terceiro, do interlocutor e do interlocutário (nível das personagens).

No primeiro nível, encontramos o autor e o leitor implícitos, entidades abstratas, que correspondem, respectivamente, ao enunciador e ao enunciatário ${ }^{27}$. É importante lembrar que o falante de carne e osso que está por trás de um texto em primeira ou em terceira pessoa não é visto, na teoria da enunciação, como um ser real, mas sim como um "autor-implícito constituído pelo texto" (Fiorin, 2002). O autor e o leitor reais pertencem ao mundo, não ao texto, e, portanto, não serão objeto de análise para a teoria. O enunciador é um sujeito do texto e criado pela existência de um discurso; é o sujeito que usa a língua e projeta, em seu enunciado, marcas de pessoa, tempo e espaço, e é por ele que a semiótica vai se interessar ${ }^{28}$.

\section{3) A categoria de tempo}

O tempo desperta fascínio e interesse nos homens de um modo geral, e tem se tornado objeto de pesquisa não só das ciências naturais, mas também das ciências humanas. Antropólogos, sociólogos, filósofos e estudiosos da linguagem se debruçam sobre a questão temporal de maneiras diversas. Em geral, o desafio está justamente em entender o que seria isso a que damos nome de tempo. Segundo Fiorin (2002: 127-129), um argumento de Santo Agostinho bastante difundido até hoje é de que o tempo não existe e, por isso, nem poderia ser mensurável, medido. Uma vez que não se tem ideia do que seja esse fenômeno cosmológico, e se ele existe ou não, é preciso entender como conseguimos sentir o tempo passar, perceber quanto tempo algo durou, falar do tempo, criar relações temporais, compreender sucessões, simultaneidades, inversões da ordem natural dos fatos.

Segundo Fiorin (2008:36), não se pode entender o tempo discursivo ou a percepção temporal como sendo "decalques do tempo físico ou cronológico". Uma confusão muito comum é achar que tempo físico, cronológico, psicológico e o tempo expresso por uma língua são a mesma coisa. Na definição aristotélica, o tempo físico pode ser medido por meio da

\footnotetext{
${ }^{27} \mathrm{O}$ termo "sujeito da enunciação", muitas vezes utilizado no lugar de enunciador, diz respeito a duas posições actanciais do discurso: a de enunciador e a de enunciatário (Greimas \& Courtés, 2012: 171).

${ }^{28}$ McCleary \& Viotti (2014) desenvolvem uma proposta para o estudo das vozes narrativas em textos sinalizados, no âmbito da teoria de espaços mentais da Linguística Cognitiva. Há diferenças significativas entre a forma como os autores analisam as instâncias enunciativas e a maneira como a semiótica greimasiana vem tratando do assunto.
} 
movimentação externa das coisas do mundo (astros, por exemplo), estabelecendo uma relação entre anterior e posterior. Segundo Benveniste (2006 [1974]), o tempo cronológico é o tempo dos acontecimentos. É esse tempo que constitui o calendário, pois é ele que mede a duração dos fatos e lhes dá uma ordem (ideia de sucessão). O tempo cronológico se baseia nos movimentos naturais recorrentes, a partir dos quais se pode fixar um momento no tempo físico e criar um eixo referencial. O tempo psicológico está ligado à ideia qualitativa da temporalidade, que, na Teoria Literária, é entendida como "a percepção da duração" do tempo por alguém (Fiorin, 2008: 30) ${ }^{29}$.

Para Benveniste, o tempo da língua é diferente dos demais e bem específico, pois comporta suas próprias divisões e tem sua própria ordem, independentemente do tempo físico ou cronológico, pois ele se constitui no ato da enunciação. Nos discursos que produzimos para contar os fatos, podemos presentificar o passado ou o futuro, tornar algo do presente passado, ou algo passado futuro, etc. Dentro da perspectiva teórica desta pesquisa, o tempo é sempre uma criação da linguagem. Para Santo Agostinho, o tempo com um suporte cosmológico traria muitos paradoxos, então, para que o tempo possa existir e ser medido deve ser criado por alguma linguagem. Para o filósofo, a experiência do tempo só ocorre no espírito do homem por meio de signos.

\subsection{1) O tempo linguístico e discursivo}

Partindo das reflexões de Santo Agostinho sobre o tempo, Fiorin (2002) mostra que o tempo, entendido como um fenômeno da linguagem, também é bastante complexo e precisa ser entendido em todas as suas facetas. Fiorin (2008: 10) adverte que o tempo não é apenas uma forma que uma língua possui para expressar suas relações temporais, como costuma postular a gramática tradicional. $\mathrm{O}$ autor o define como sendo uma categoria gramatical "que permite situar os acontecimentos como presentes, pretéritos ou futuros, em relação a um marco referencial presente, pretérito e futuro, estabelecido a partir do momento da enunciação" (Fiorin, 2008: 11). Para Benveniste e Fiorin, o tempo linguístico tem o momento da enunciação como eixo ordenador e gerador e está relacionado à ordenação dos estados e transformações narrativas que aparecem em um texto.

Como já foi dito, o tempo linguístico não segue as divisões do tempo cronológico, mas também possui ordem (sucessividade e simultaneidade), duração e direção (retrospectiva e

\footnotetext{
${ }^{29}$ Segundo Fiorin (2008), a passagem do tempo pode ser percebida de várias maneiras: neutra, acelerada (intensa) ou lenta (extensa).
} 
perspectiva), que são subjetivas, criadas pelo enunciador. Os marcos temporais, no interior de um texto, serão colocados em relação ao agora da enunciação, que também poderá ser construído em qualquer momento cronológico. Os diferentes tempos linguísticos e as diferentes relações temporais serão criadas sempre a partir de um ponto de referência instaurado no texto.

Fiorin (2002: 146), seguindo as ideias de Reichenbach (1947), as ideias de Benveniste, propõe uma estrutura do tempo linguístico em português. Segundo o autor, há três momentos estruturalmente relevantes na construção dos sistemas temporais: o momento da enunciação (ME), que é o momento do presente implícito; o momento da referência (MR), e o momento do acontecimento (MA). Dependendo do ponto de referência a partir do qual os tempos linguísticos se organizam em um discurso e levando em consideração a categoria topológica de concomitância e não-concomitância em relação à enunciação, podemos ter dois grandes sistemas temporais na língua: (i) o sistema dos tempos enunciativos (os momentos dos acontecimentos estão relacionados ao momento de referência presente) e (ii) o sistema dos tempos enuncivos (os momentos dos acontecimentos relacionados ao momento de referência pretérito ou de referência futuro, ou seja, quando o momento de referência é anterior ou posterior ao momento da enunciação). No interior desses sistemas, novamente se aplica a ideia de concomitância e nãoconcomitância. O momento dos acontecimentos, portanto, poderá ser presente, concomitante ao MR instaurado no texto, ou não-concomitante a esse ponto de referência e, assim, ser anterior (pretérito) ou posterior (futuro) a ele.

O esquema, abaixo, ilustra a proposta da estrutura geral do tempo linguístico de Fiorin (2002):

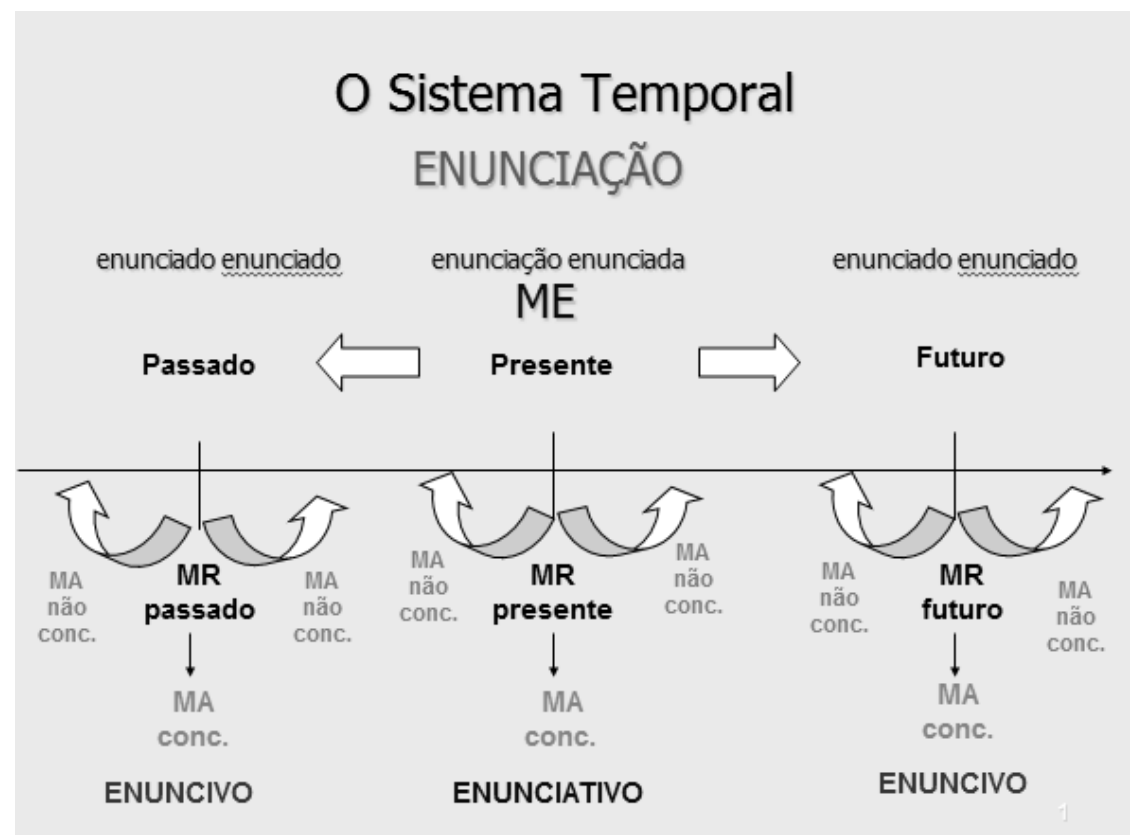


Na esquematização dos sistemas temporais acima, é possível perceber que o tempo é um ponto de referência que se instaura no texto e a partir do qual se constrói cada um dos sistemas temporais citados anteriormente, ao se estabelecer o que vem antes e o que vem depois desse ponto $^{30}$.

Quando observamos o sistema enunciativo descrito por Fiorin (2002), percebemos que, se temos como referência o tempo presente, concomitante ao momento da enunciação, então, podemos ter o acontecimento no próprio presente, ou no passado ou no futuro ${ }^{31}$. No português, esses tempos do sistema enunciativo são representados pelas formas verbais no modo indicativo, no presente, pretérito perfeito simples (pretérito perfeito 1) e no futuro do presente. O sistema enuncivo, não concomitante ao momento da enunciação, pode ser expresso pelo pretérito perfeito 2 (a forma é a mesma do pretérito perfeito 1), pretérito imperfeito, pretérito mais-que-perfeito, futuro do pretérito simples e futuro do pretérito composto, no caso do MR passado, e futuro do presente simples, futuro do presente composto e futuro composto do subjuntivo, no caso de MR futuro.

O discurso permite, então, que a categoria de tempo se realize e construa, no interior dos enunciados, diferentes temporalidades. Segundo Fiorin (2002: 229), o tempo linguístico não se organiza apenas em algumas partes do texto, formando apenas microssistemas temporais, que ordenam os acontecimentos, no interior dos enunciados. Também há temporalizações gerais, globais, que ordenam conjuntos de acontecimentos, ou seja, partes maiores do texto. Para Fiorin, é necessário, então, distinguir, o que é o tempo, essa categoria que estabelece os sistemas temporais enunciativos ou enuncivos em uma língua, e o que é a temporalização, esse processo de discursivização do tempo em micro ou macro temporalidades.

Como já foi dito, para a semiótica, quando se estuda a sintaxe discursiva de um texto, procura-se explicar a temporalização, a espacialização e a actorização que ocorreram no discurso.

\footnotetext{
${ }^{30} \mathrm{O}$ esquema proposto aqui é um pouco diferente dos diagramas que ilustram o estudo de Fiorin (2002). A forma de representar, nesta tese, os tempos do sistema enunciativo e do sistema enuncivo, em uma única figura, resgatando a ideia da conceitualização do tempo como uma linha horizontal, pareceu, neste momento, mais fácil para a compreensão de todas essas relações possíveis.

${ }^{31} \mathrm{Na}$ classificação de tempo enunciativo, descrita em Fiorin (2002), o presente é entendido como o tempo que marca uma coincidência entre o momento do acontecimento, o momento de referência e o momento de enunciação. Há, no entanto, três formas de relacionar o momento de referência presente e o momento de enunciação, uma vez que o momento da enunciação é difícil de ser delimitado e o presente é, então, uma abstração, pois pode se recompor com instantes que acabaram de passar e com instantes que ainda irão ocorrer. Há, assim, o presente pontual, em que o MR coincide com o ME; o presente durativo, quando o MR é mais longo que o ME, e o presente gnômico, quando o MR é ilimitado e o MA também não tem limite.
} 
A temporalização é a transformação das relações de causa e consequência do nível narrativo, nesse nível mais concreto do percurso gerativo de sentido. Ela ajuda o enunciador a criar e a concretizar, no texto, um simulacro de como o homem tem a experiência do tempo, como ele vê e entende a ordem das coisas e dos acontecimentos no mundo. A temporalização de um discurso envolve (i) a programação temporal; (ii) a localização temporal e (iii) a aspectualização ${ }^{32}$.

Segundo Greimas \& Courtés (2012), a programação temporal é um dos principais componentes discursivos para converter as estruturas narrativas, o eixo das pressuposições, da ordem lógica dos programas narrativos, em estruturas discursivas, o eixo das consecuções. A programação temporal do texto é um processo de encadeamento dos acontecimentos, que pode ocorrer por meio de três procedimentos: a sucessão, a simultaneização e a inversão. Ela é, portanto, a responsável pela criação das ideias de sucessão ou concomitância, para gerar efeitos de sentido de proximidade com a realidade ou de discordância com a ordem natural das coisas. É a programação temporal que atribui aos programas narrativos uma disposição na linha do tempo, segundo a categoria anterioridade/posterioridade, e também a medida do tempo em duração. Dessa forma, a programação temporal também está ligada à aspectualização no discurso.

Segundo Fiorin (2008), a sucessão diz respeito à forma como os acontecimentos são ordenados numa linha temporal. O português, por exemplo, dispõe de advérbios e locuções adverbiais sequenciadoras, como "depois”, “em seguida”, “depois de dois dias”, etc., e de orações temporais, para criar, nos textos verbais, a ideia de que os acontecimentos se sucedem. A libras conta também com itens lexicais que correspondem a esses advérbios do português, para criar as a ordem dos fatos em seus textos. A simultaneização é quando diferentes eventos ocorrem em um mesmo intervalo de tempo. Na linguagem verbal, linear, é preciso contar com advérbios, ou tempos verbais e até o procedimento da descrição, que indica uma concomitância durativa a um momento, para construir os acontecimentos simultâneos. Nas línguas de sinais, há a possibilidade de o sinalizador realizar um evento com cada mão, ou com o corpo e as mãos. Também há, nas línguas sinalizadas, o uso de descrições. Por fim, a inversão é o procedimento discursivo que muda a ordem natural, e antecipa acontecimentos que viriam depois. Em português, também se conta com advérbios para inverter a ordem dos fatos. No cinema, e em outras linguagens sincréticas, há uma quantidade grande de recursos, visuais, sonoros, e até verbais, para fazer essas

\footnotetext{
${ }^{32}$ Segundo Greimas \& Courtés (2012: 39), todo discurso temporalizado comporta dois tipos de produtores de efeitos de sentido: a temporalização e a aspectualização. Enquanto a temporalização está ligada à instauração de categorias no enunciado, a aspectualização atua como se fosse um "ponto de vista" sobre o tempo das ações narradas, transformando-as em "processo" e dando-lhes duratividade ou pontualidade, entre outros.
} 
inversões temporais. Nas línguas de sinais, isso também é possível, com o uso de determinados sinais que têm função adverbial de tempo, como será mostrado no capítulo 4.

Para Greimas \& Courtés, a localização temporal, por sua vez, é um procedimento da temporalização do discurso responsável pela construção de um sistema de referências, no interior do texto, o que permite que se situem temporalmente os programas narrativos. Como já foi dito, as relações temporais são construídas a partir de um ponto referencial (sistema enunciativo tempos do agora - ou sistema enuncivo - tempos do então). Dois procedimentos discursivos são responsáveis pela instalação dos tempos nos enunciados, ou seja, pela localização temporal, pela criação desses sistemas de referência e de todas as relações internas entre os acontecimentos de um texto: a debreagem e a embreagem, explicadas na próxima seção deste capítulo.

A programação temporal e a localização temporal são, portanto, duas maneiras de construção das temporalidades no discurso ${ }^{33}$. Para a semiótica greimasiana, há, portanto, pelo menos dois tipos de temporalidades: a da enunciação (da narração) e a do enunciado (do narrado). A temporalidade da enunciação é aquela em que o narrador conta os fatos. A temporalidade do enunciado é aquela em que os acontecimentos ocorreram. Os tempos da enunciação pertencem à programação temporal do texto e os tempos do enunciado à localização temporal. Essas duas formas de temporalizações serão determinadas pelo tempo linguístico. Como tanto a programação quanto a localização temporais são regidas pela instância enunciativa, ou seja, são determinadas pelo enunciador, é possível aplicar esses mesmos mecanismos de enunciação, de debreagem e embreagem, para analisar tanto o tempo da narração quanto o tempo do narrado.

Entende-se que o tempo de uma narração (o tempo do ato de narrar) é sempre o presente (o chamado presente implícito ou presente da enunciação), pois este é o momento em que se fala. Esse tempo presente é, logicamente, posterior aos acontecimentos que serão narrados e é, consequentemente, anterior ao texto que será enunciado. Mas é ele que contém os tempos que serão instaurados no discurso e que organizarão os eventos dentro da história narrada. É a partir

\footnotetext{
${ }^{33}$ Fiorin (2002) descreve a proposta do Genette (1972), que distingue três "aspectos da realidade narrativa": a história, que é o conteúdo que é narrado; a narrativa propriamente dita, que é o enunciado, e a narração, que é a instância da enunciação, de produção da história e do enunciado dela. Para Genette, cada um desses aspectos do texto tem sua temporalidade. Fiorin aponta que, do ponto de vista estruturalista, o narratólogo encontra dificuldade em relacionar essas três temporalidades em sua análise. A semiótica, entretanto, consegue resolver essa questão, com a proposta do percurso gerativo de sentido, que propõe uma separação entre um nível narrativo, que seria o nível dos acontecimentos, da história que é contada, do nível discursivo, em que entra o enunciado dessa história, o discurso produzido e, logicamente, a sua instância de produção. Com essa separação, não se tem mais três temporalidades, pois no nível narrativo não há temporalização, mas sim, relações de pressuposição lógicas entre os acontecimentos.
} 
desse presente da enunciação (o chamado presente zero) que se constroem os demais tempos dentro de um texto. Embora se prefira o pretérito para a narração em si, também é, segundo Fiorin (2002: 234), possível que se crie uma narração em que o tempo do narrado seja concomitante ao tempo da enunciação (narrativas no presente, como a narração de um jogo de futebol) e, ainda, um texto em que o tempo do narrado seja posterior ao da narração (narrativas proféticas, por exemplo).

Em geral, espera-se, portanto, que uma história sobre algo que já aconteceu seja contada no pretérito, que é o tempo por excelência do narrado (Fiorin, 2002: 234), e que este seja o eixo organizador das relações temporais, ao longo de uma história. Mas isso nem sempre ocorre. É possível, por meio de debreagens e embreagens temporais, narrar um fato do passado no presente. O enunciador pode, portanto, deslocar o ponto de referência para o momento da enunciação e presentificar um fato de outro tempo.

\section{4) Os mecanismos discursivos de instauração de tempo}

A semiótica greimasiana entende que a instauração de pessoa, espaço e tempo no enunciado pode ser feita por meio de dois mecanismos discursivos: as debreagens e as embreagens. A seguir, serão apresentadas as características desses procedimentos discursivos, com ênfase na sua capacidade de realizar a localização temporal nos textos.

\subsection{1) As debreagens}

A debreagem consiste, num primeiro momento, em um desligamento do sujeito que enuncia, do espaço em que ele enuncia e do tempo em que ocorre a enunciação. A debreagem é, portanto, uma espécie de negação da instância produtora, porque o ato de enunciar é o de criar um objeto que, em nenhum momento, poderá ser equivalente a sua instância de produção, mesmo quando a simula. Quando se projeta, no enunciado, um agora, por exemplo, ele não se confunde

com o agora da enunciação pressuposta e, portanto, é, em princípio, uma negação desse presente e uma tentativa de simulação dele. Tudo o que acontece no enunciado pertence a outra instância, diferente daquela em que ele foi produzido. A debreagem temporal cria nos textos efeitos de nãoconcomitância temporal (anterioridade ou posterioridade) ou de simultaneidade entre os atos de narrar e os acontecimentos narrados. Ela possibilita, portanto, o distanciamento ou a simulação da enunciação no enunciado. 
Como já foi dito, um enunciado pode conter expressões de pessoa, de espaço ou de tempo, que evidenciam o processo enunciativo, ou seja, um processo que remete à enunciação. Quando isso ocorre, o ponto de referência eu está projetado no interior do texto (debreagem enunciativa). Um enunciado, no entanto, também pode não apresentar elementos enunciativos, mas apenas elementos enuncivos, que não remetem à instância de sua produção (debreagem enunciva). Também é necessário distinguir o tempo da enunciação, da narração, do tempo do enunciado, do narrado. Para poder analisar as diferenças de temporalidade nesses dois níveis do texto, é preciso diferenciar, portanto, as debreagens (enunciativas ou enuncivas) da enunciação e as debreagens (enunciativas ou enuncivas) do enunciado, descritas a seguir:

- debreagem enunciativa da enunciação: quando se projetam no enunciado as categorias da enunciação, e os comentários do narrador aparecem, no mesmo tempo do narratário, simulando uma situação de enunciação, no presente. São bons exemplos desse tipo de debreagem as histórias narradas em primeira pessoa, em que as marcas de narrador são explicitadas no enunciado, trazendo para ele, a instância de produção.

\section{Eu vou te contar uma história sobre o Cebolinha.}

- debreagem enunciva da enunciação: quando a instância da enunciação não se enuncia, ou seja, o enunciador apaga as marcas do tempo da enunciação, deixando-as implícitas. São exemplos desse tipo de debreagens textos narrados em terceira pessoa, em que temos apenas a temporalização do enunciado, dos eventos que estão sendo narrados. O narrador não aparece explicitamente, mas sabemos que a instância da enunciação, da narração, é pressuposta, e é um presente.

\section{Cebolinha caiu e se machucou.}

- debreagem enunciativa do enunciado: quando os acontecimentos são narrados nos tempos do sistema enunciativo, com o propósito de se criar um efeito de sentido de concomitância com o momento da enunciação, ou de simultaneidade entre o que é narrado e a própria narração. É o que ocorre nas narrações de futebol, por exemplo.

\section{Cascão está com a bola e chuta mal. A bola cai no lago.}


- debreagem enunciva do enunciado: quando os acontecimentos são narrados nos tempos do sistema enuncivo. São exemplos desse tipo de debreagem os textos de antecipação, que se organizam a partir de um marco temporal do futuro, e os de retrospectiva, que se organizam a partir de um ponto de referência do passado.

\section{Naquele dia, Cebolinha estava muito contente.}

\section{Um dia, Cebolinha conseguirá ser um herói.}

A ideia de conceber, no estudo do tempo, uma debreagem enunciativa da enunciação e uma debreagem enunciativa do enunciado é fundamental para se entender, por exemplo, as diferenças em relação à instauração do tempo entre dois tipos de textos: o texto que narra, no presente, algo que está acontecendo no presente da enunciação, e o texto que narra, no presente, um fato que não está ocorrendo no momento da enunciação, mas que, no texto, é narrado como presente, para se criar uma ilusão de proximidade temporal ou um efeito de sentido de verdade, realidade ${ }^{34}$.

É possível que ocorram, em um mesmo texto, debreagens enunciativas e enuncivas de tempo. Além disso, pode acontecer de ter, em um discurso, uma parte em que é explicitado o tempo da narração e, em outra parte, o tempo do narrado, considerando, assim, as macrotemporalidades a que se refere Fiorin (2012: 229). Isso ocorre, por exemplo, nos textos "História do Gibi 1" e "Metáfora - O escorpião e a tartaruga" do corpus desta pesquisa, como será mostrado no capítulo 3.

O sujeito da enunciação também pode operar com debreagens internas (debreagens de segundo grau). Essas debreagens são responsáveis pela produção de simulacros de diálogos nos textos. O tempo instaurado por esse mecanismo interno de enunciação costuma ser o presente, pois os diálogos simulam uma situação de fala. Instala-se, nessa instância discursiva, um novo eixo ordenador de relações temporais, e, nesse caso, novamente, poderão aparecer tempos enuncivos e enunciativos nos discursos citados (nos enunciados que compõem a fala das personagens de uma história, por exemplo).

\footnotetext{
${ }^{34}$ Isso também é diferente do texto em que ocorre uma embreagam temporal e há uma presentificação dos fatos. Nesse último caso, aparecerão marcas no enunciado de que houve uma neutralização proposital e que um novo efeito está sendo criado no discurso.
} 
Segundo Fiorin (2002: 72), quando o narrador delega sua palavra a uma personagem, que, então, passa a dizer $e u$ no discurso, ocorre uma enunciação reportada. O discurso reportado é uma citação feita, pelo narrador, do discurso de outra pessoa. Há três estratégias tradicionalmente descritas pelas gramáticas para fazer a citação de discurso: o discurso direto, o discurso indireto e o discurso indireto livre. No discurso direto, o narrador é um actante debreado em uma primeira instância do discurso e se transforma em um novo actante, em uma nova instância enunciativa, que é a do diálogo. Para a teoria da enunciação, o discurso direto envolve, então, dois níveis enunciativos: o do narrador e o dos interlocutores.

Para Fiorin (2002: 78), os discursos reportados, de uma maneira geral, precisam ser marcados para que o enunciatário perceba a distinção entre o discurso citante (o usado pelo narrador) e o discurso que está sendo citado (a fala do interlocutor ou das personagens). Nas línguas orais, quando esse tipo de discurso ocorre na fala, costuma haver pausa entre as diferentes instâncias enunciativas (entre as diferentes falas) e há uma alteração na elocução. Nas línguas de sinais, percebe-se que há alteração na direção do olhar e movimento do corpo de quem sinaliza. Quando o sinalizador olha para frente, em geral, está se comportando como narrador. Mas quando desvia o olhar para um dos lados e movimenta seu torso nessa direção, em geral, está interpretando uma das personagens da história, como também será mostrado mais adiante nesta tese. Nesse caso, toda sua sinalização de fala será de outra pessoa, não mais do narrador. Nas línguas de sinais, essa passagem de narrador para personagem, muitas vezes, é muito difícil de segmentar. Nem sempre dá para saber, com certeza, o que é enunciado do nível do narrador e o que é enunciado do nível do interlocutor, como ocorre também nos discursos indiretos livres das línguas orais.

\subsection{2) As embreagens}

Para a teoria da enunciação, ainda há outro mecanismo discursivo de instauração de pessoa, espaço e tempo: a embreagem. Segundo Greimas \& Courtés (2012: 159-162), embreagem é o efeito de retorno à enunciação, produzido pela neutralização da oposição dos termos da categoria de pessoa, ou de tempo, ou de espaço. Com a embreagem, temos a ilusão de trazer a instância produtora para o enunciado. Toda embreagem pressupõe uma operação de debreagem anterior. As embreagens temporais consistem no uso de um tempo com valor de outro, com o objetivo de se criar algum efeito de sentido no texto. 
Para Fiorin (2008:21), debreagem e embreagem devem ser entendidos como mecanismos discursivos distintos. Segundo o autor, a debreagem é uma operação formal que permite que se coloque o presente da enunciação em qualquer momento cronológico, em um texto, mas sempre causando a impressão de que "a temporalidade linguística simula a temporalidade do mundo". A embreagem, no entanto, é um mecanismo que de fato mostra que o tempo linguístico é uma criação da linguagem. Ao se neutralizar as diferenças entre dois sistemas - enunciativo e enuncivo -, por exemplo, produz-se o sentido de que o tempo é uma construção do enunciador: ele pode presentificar o passado ou o futuro. Embora os dois mecanismos gerem efeitos de sentido em um texto, há uma diferença na forma como elas acontecem em um discurso. A debreagem dá referência às instâncias enunciativas e enuncivas por meio de um enunciado. A embreagem faz o contrário. Ela tira qualquer referência, para dar um novo valor ao enunciado. Uma embreagem nunca pode ocorrer sem uma debreagem prévia. Portanto, ela é um mecanismo que se aplica após uma debreagem, quando se quer afetar o sentido de um enunciado, neutralizando o valor das pessoas, dos espaços ou dos tempos que foram debreadas. A debreagem, por sua vez, pode ocorrer sem que haja qualquer embreagem no texto ${ }^{35}$.

Fiorin (2002) fez um levantamento de noventa possibilidades de se fazer uma embreagem temporal no português brasileiro. Apresento, a seguir, uma dessas possibilidades, usando um exemplo do próprio autor:

“Em 1858, a Companhia das Índias é suprimida, o Império Mongol igualmente, e o vicereinado é instaurado”. (FIORIN, 2002:207)

A embreagem pode ser enunciativa ou enunciva, dependendo das marcas que são deixadas depois da neutralização. No exemplo acima, o texto se organizou a partir de um ponto de referência no passado, mas as ações, concomitantes a esse momento, foram narradas no presente, como se estivessem acontecendo no mesmo instante em que o enunciado foi produzido. Esse é um caso de uma embreagem enunciativa de tempo. A flexão verbal que indica presente foi usada com valor de um tempo enuncivo, como pretérito perfeito 1, e é a marca da embreagem.

\footnotetext{
${ }^{35}$ Alguns semioticistas franceses têm uma forma diferente de se referir aos mecanismos discursivos débrayage e embrayage. Bertrand (2003: 90-91) chama de debreagem a operação que consiste em projetar no enunciado um não-eu, um não-aqui e um não-agora, e que cria, assim, os efeitos de objetividade no texto. Para o autor, debreagem seria só a debreagem enunciva, nos termos de Fiorin (2002). Para Bertrand, o termo embreagem refere-se ao mecanismo de instaurar no enunciado as marcas ou categorias da enunciação, ou seja, o que Fiorin chama de debreagem enunciativa.
} 


\subsubsection{1) A embreagem heterocategórica}

Fiorin (2002: 51) destaca uma importante distinção feita por Greimas \& Courtés (2012) sobre dois tipos de embreagem: as homocategóricas e as heterocategóricas. Segundo o autor, nos textos, podem ocorrer, com frequência, as embreagens homocategóricas, quando a categoria da debreagem anterior e a categoria afetada pela neutralização são a mesma, por exemplo, um tempo enuncivo é usado com o valor de um tempo enunciativo, ou vice-versa.

Na letra da canção Eduardo e Mônica, de Renato Russo, a seguir, podemos analisar que ocorre uma embreagem temporal logo na segunda estrofe, com o uso do pretérito perfeito 1, considerando um MR presente, com valor de pretérito perfeito 2, que será usado a partir da terceira estrofe, quando aparece uma marca de MR passado no texto: "um dia". Nesse momento, é criado no texto um efeito de proximidade do evento, uma presentificação do fato do passado. $\mathrm{Na}$ oitava estrofe da letra, novamente aparece uma neutralização temporal. O uso da expressão temporal "a dois anos atrás" ancora o evento de "construir uma casa" no MR presente, embora, no texto, ele tenha valor de posterioridade ao MR passado, instaurado a partir da terceira estrofe. Os protagonistas provavelmente construíram sua casa dois anos depois da sequência de eventos narrados nas estrofes anteriores, na mesma época em que os gêmeos nasceram. Sabemos que não pode ter sido há dois anos em relação ao momento presente, porque, na nona estrofe, o eu lírico menciona que nessas férias o casal não viajará, porque o filho está de recuperação, ou seja, no presente, os gêmeos já possuem idade para ir para escola, e não têm apenas dois anos. O uso de uma expressão do sistema enunciativo de tempo em um texto em que o MR é passado e desencadeia um tempo enuncivo cria um efeito de sentido de verdade, de aproximação com o presente.

\section{Eduardo e Mônica \\ Renato Russo}

Quem um dia irá dizer que existe razão

Nas coisas feitas pelo coração? E quem irá dizer Que não existe razão?

Eduardo abriu os olhos mas não quis se levantar Ficou deitado e viu que horas eram Enquanto Mônica tomava um conhaque No outro canto da cidade

Como eles disseram 
Eduardo e Mônica um dia se encontraram sem querer E conversaram muito mesmo pra tentar se conhecer Foi um carinha do cursinho do Eduardo que disse

- Tem uma festa legal e a gente quer se divertir

Festa estranha, com gente esquisita

- Eu não estou legal, não aguento mais birita

E a Mônica riu e quis saber um pouco mais

Sobre o boyzinho que tentava impressionar

E o Eduardo, meio tonto, só pensava em ir pra casa

- É quase duas, eu vou me ferrar

Eduardo e Mônica trocaram telefone

Depois telefonaram e decidiram se encontrar

$O$ Eduardo sugeriu uma lanchonete

Mas a Mônica queria ver o filme do Godard

Se encontraram então no parque da cidade

A Mônica de moto e o Eduardo de camelo

O Eduardo achou estranho e melhor não comentar

Mas a menina tinha tinta no cabelo

Eduardo e Mônica eram nada parecidos

Ela era de Leão e ele tinha dezesseis

Ela fazia Medicina e falava alemão

E ele ainda nas aulinhas de inglês

Ela gostava do Bandeira e do Bauhaus

De Van Gogh e dos Mutantes

Do Caetano e de Rimbaud

E o Eduardo gostava de novela

E jogava futebol-de-botão com seu avô

Ela falava coisas sobre o Planalto Central

Também magia e meditação

E o Eduardo ainda estava

No esquema "escola, cinema, clube, televisão"

E, mesmo com tudo diferente

Veio mesmo, de repente

Uma vontade de se ver

E os dois se encontravam todo dia

E a vontade crescia

Como tinha de ser

Eduardo e Mônica fizeram natação, fotografia

Teatro e artesanato e foram viajar

A Mônica explicava pro Eduardo

Coisas sobre o céu, a terra, a água e o ar

Ele aprendeu a beber, deixou o cabelo crescer

E decidiu trabalhar

E ela se formou no mesmo mês

Em que ele passou no vestibular

$\mathrm{E}$ os dois comemoraram juntos

E também brigaram juntos, muitas vezes depois

E todo mundo diz que ele completa ela e vice-versa

Que nem feijão com arroz 
Construíram uma casa uns dois anos atrás

Mais ou menos quando os gêmeos vieram

Batalharam grana e seguraram legal

A barra mais pesada que tiveram

Eduardo e Mônica voltaram pra Brasília

E a nossa amizade dá saudade no verão

Só que nessas férias não vão viajar

Porque o filhinho do Eduardo

Tá de recuperação

E quem um dia irá dizer que existe razão

Nas coisas feitas pelo coração? E quem irá dizer

Que não existe razão?

(Disponível em: https://www.letras.mus.br/legiao-urbana/22497/)

Em outra canção popular e mais recente, Hoje eu sonhei com você, do grupo de pagode Harmonia do Samba, a seguir, esse mesmo tipo de embreagem homocategórica de tempo também ocorre e cria efeitos de sentido de proximidade e presentificação. No verso final da letra, há uma neutralização temporal. O presente é usado com valor de futuro e, portanto, há uma aproximação de algo que ainda vai acontecer (“amanhã”), o que gera mais credibilidade à informação, ao fato, tornando-o mais real. Isso condiz com a ideia do enunciador de que tem certeza do que quer e do quanto tudo está acontecendo rápido entre o casal e que tudo pode até ser um sonho.

\section{Hoje eu sonhei com você}

Harmonia do Samba

(...)

Que coisa louca, teu beijo me leva pro céu

A noite toda contigo eu não corro perigo, é só lua de mel

E se for sonho, então eu não quero acordar

Ontem te olhando, hoje ficando, amanhã eu já quero casar

(Disponível em: https://www.letras.mus.br/harmonia-do-samba/hoje-eu-sonhei-com-voce)

O outro tipo de embreagem possível nos discursos é a heterocategórica, que ocorre quando as categorias envolvidas na debreagem e na embreagem que a segue são diferentes. Em português, um bom exemplo é, segundo Fiorin (2002: 51), o uso de "uma medida temporal para indicar uma medida espacial", por exemplo: 
As embreagens heterocategóricas podem permitir que, quando não houver marcas explícitas de uma categoria como espaço ou tempo, por exemplo, em um texto, seja possível entender o espaço ou o tempo instaurado por meio das outras categorias discursivas que foram instaladas no enunciado. A hipótese é a de que, uma vez que uma categoria temporal e uma categoria espacial, por exemplo, podem sofrer uma neutralização ao ponto de uma ser usada para indicar a outra, em um enunciado como este acima, então, qualquer categoria pode ser dada por outra, o que reforça a ideia de que pessoa, espaço e tempo estão inteiramente ligados e, quando não são explicitados, podem ser pressupostos uns pelos outros.

No texto, Preciso dizer que te amo, de Dé, Bebel e Cazuza, abaixo, é possível observar que ocorre uma debreagem enunciativa de tempo, pois é projetado, no enunciado, um tempo presente, construído a partir do MR presente, "sei”, "dá", "preciso". Não há, no entanto, uma indicação explícita do espaço em que as ações do texto ocorrem. Podemos construir um espaço do aqui do enunciador a partir das outras categorias instauradas explicitamente, e podemos deduzir que o local do início, da primeira à última estrofe, talvez também seja enunciativo. Essa confirmação é feita, se considerarmos que, tanto a pessoa quanto o tempo, nesse texto, são enunciativos. Poderíamos, então, propor que, logo na primeira estrofe, o espaço do aqui seja dado pelas categorias de tempo, do agora, e de pessoa, do eu-tu.

\section{Preciso dizer que te amo Dé, Bebel e Cazuza}

Quando a gente conversa Contando casos besteiras Tanta coisa em comum Deixando escapar segredos

E eu nem sei que hora dizer

Me dá um medo ( que medo )

É que eu preciso dizer que eu te amo

Te ganhar ou perder sem engano

É eu preciso dizer que eu te amo

Tanto 
E até o tempo passa arrastado

Só pra eu ficar do teu lado

Você me chora dores de outro amor

Se abre e acaba comigo

e nessa novela eu não quero ser teu amigo

Eu já não sei se eu tô misturando

Ah, eu perco o sono

Lembrando em cada riso teu qualquer bandeira

Fechando e abrindo a geladeira a noite inteira

É que eu preciso dizer que eu te amo

Te ganhar ou perder sem engano

É eu preciso dizer que eu te amo

Tanto

(Disponível em: https://www.letras.mus.br/cazuza/45007/)

Outro texto que parece fazer uso da embreagem heterocategórica é o livro "Quem matou Palomino Molero?”, do escritor peruano Mario Vargas Llosa. Nesse texto, o recurso é usado para marcar diferenças de tempo dos acontecimentos narrados por meio da categoria de pessoa e espaço. Trata-se de um romance policial, de 1986, que conta a história de um crime que precisa ser desvendado. Nesse texto, o narrador, por meio de muitas debreagens internas, desloca suas personagens no tempo, ou, como descreve Fiorin (2008: 26), marca a simultaneidade de eventos, ao misturar falas de diálogos ${ }^{36}$. Entre um capítulo e outro, há mudança temporal, mas isso não é ancorado verbalmente. Há uma marcação de espaço e novos diálogos, que mostram para o leitor que a personagem central da história está num espaço-tempo diferente daquele do capítulo anterior.

Ao que tudo indica, em alguns textos em libras analisados nesta tese, também parece ocorrer uma embreagem heterocategórica na marcação do tempo. Nos discursos sinalizados em que não aparecem marcas temporais explícitas (itens lexicais ou determinados gestos corporais), o tempo parece ser construído a partir das categorias de pessoa e espaço, como será mais bem discutido no capítulo 4.

\footnotetext{
${ }^{36}$ Fiorin (2008) analisou, em seu estudo, o livro "Conversa na Catedral”, também de Mário Vargas Llosas.
} 
1.4.3) Os efeitos de sentido das debreagens e embreagens de tempo

As debreagens de primeiro e segundo grau ou embreagens empregadas num discurso geram efeitos de sentido variados no texto. Segundo Barros (2011: 55), todo discurso é criado para que um destinador possa persuadir seu destinatário de que o que é dito é verdadeiro (ou falso). Portanto, os mecanismos de instauração de pessoa, espaço e tempo, segundo a autora, contribuem para se criar a ilusão da verdade ou da falsidade, nos discursos. Além disso, outros efeitos básicos são gerados pelas categorias enunciativas: o de proximidade ou distanciamento da enunciação e o de realidade ou referente.

O primeiro efeito, de proximidade e distanciamento, é o que caracteriza textos subjetivos e objetivos, respectivamente. As debreagens e embreagens enunciativas produzem o efeito de subjetividade, e as debreagens e embreagens enuncivas, de objetividade. Já o segundo efeito, de realidade ou referente, é produzido principalmente por debreagens internas presentes no interior dos textos. Segundo Fiorin (2008: 19), as embreagens temporais, ao produzirem efeito de aproximação ou distanciamento da enunciação, podem criar, nos textos, os sentidos de realidade e virtualidade (efeitos de ficcionalidade), presentificação e despresentificação, acabamento e inacabamento.

Segundo Greimas \& Courtés (2012: 161), a embreagem, em especial, pode produzir, no texto, dois tipos de ilusão: enunciativa (quando se refere ao sujeito da instância da enunciação, dentro do próprio texto) e a referencial (quando faz referência ao objeto do mundo real - seres, acontecimentos, etc., que se encontram fora do texto). Desse modo, quando usamos uma pessoa ou um espaço ou um tempo com valor, respectivamente, de outra pessoa ou espaço ou tempo, podemos ter ilusões enunciativas ou ilusões referenciais. O efeito de proximidade da enunciação, então, pode ser entendido como uma ilusão enunciativa ${ }^{37}$.

Um exemplo de ilusão enunciativa que ocorre na instauração da pessoa do discurso é o que aconteceu durante a performance do cantor Roberto Carlos, em um show, ao interpretar a canção "Esse cara sou eu"38. Com base no estudo de Tatit (2014), pode-se dizer que ocorre uma

\footnotetext{
${ }^{37}$ As análises apresentadas neste trabalho se baseiam em especial em uma análise feita por Luiz Tatit, que foi apresentada durante sua comunicação, intitulada A ilusão enunciativa no mundo da canção (Simpósio 10: Perspectivas atuais dos estudos semióticos), no Congresso Nacional do Mackenzie - Letras em Rede - Linguagens e Saberes, no dia 22 de agosto de 2012, e que, posteriormente, foi publicada sob a forma de um artigo, Ilusão enunciativa na canção (ver Tatit, 2014).

${ }^{38}$ O Show "Reflexões" foi gravado no dia 21 de dezembro de 2012, no Citibank Hall, no Rio de Janeiro, e foi promovido pela Rede Globo de Televisão e exibido, na TV aberta, no dia 25 de dezembro de 2012. A canção "Esse
} 
embreagem de pessoa em um trecho da música, o que gera um efeito de ilusão enunciativa de pessoa $^{39}$. No início do show, o cantor disse que fizera essa canção para falar do "cara" que "toda mulher gostaria de ter", "o cara que todo homem gostaria de ser", e terminou, usando a primeira pessoa, com a seguinte frase: "o cara que eu tento ser". Quando o cantor pronunciou a palavra $e u$, fez um gesto dêitico concomitante com sua fala, que indica $1^{\mathrm{a}}$ pessoa. Ele encostou a mão direita aberta em seu peito, como é possível verificar na figura 1(a), a seguir. Durante a execução da música, ao cantar a frase refrão que dá título à canção ("Esse cara sou eu”), Roberto Carlos também fez dois outros gestos de apontamento que estabeleceram relações dêiticas, como é possível observar também nas figuras 1 (b) e 1 (c).

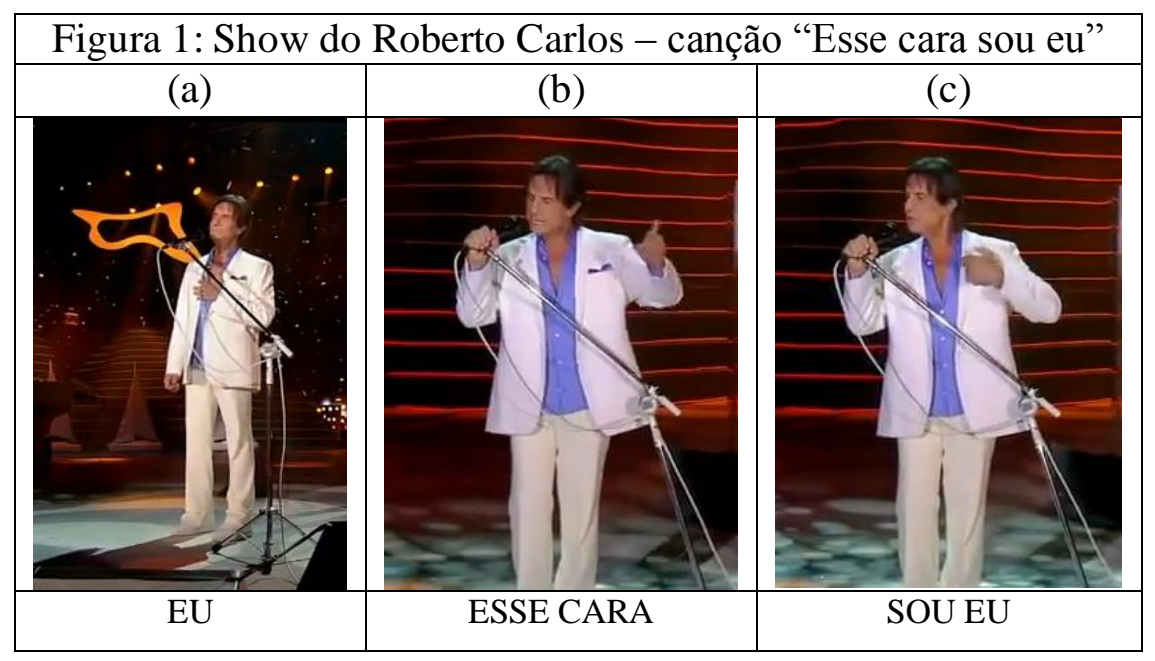

Quando o cantor pronunciou a expressão esse cara, ele apontou, com a mão direita, dedo indicador em riste, para a esquerda, para fora do seu corpo, como se indicasse alguém nessa direção. E, quando disse sou eu, o mesmo dedo em riste se voltou para seu corpo e encostou em seu peito, para se referir a si mesmo, fazendo, assim, uma mescla entre o eu, instaurado no discurso, e о eu que estava produzindo esse enunciado cantado, naquele momento, naquele

cara sou eu" tem letra e música compostas por Roberto Carlos e foi lançada em novembro de 2012, em um CD compacto composto de mais três canções ("Furdúncio", "A Mulher que eu amo" e "A Volta"). Segue o link para acessar um vídeo com a canção no site do youtube: http://youtu.be/oOmPXFJ66UO.

${ }^{39}$ Como apontado por Fiorin (cp), a ilusão enunciativa é criada em todas as situações em que se tem a instauração do presente. As debreagens enunciativas tanto da enunciação quanto do enunciado são formas de o enunciador simular, no texto, o momento da enunciação. Nunca será o presente, tempo crônico, mas sim, sempre um simulacro do tempo do mundo. 
show $^{40}$. As figuras 1 (b) e 1 (c), acima, mostram esses apontamentos gestuais dêiticos que reforçam a embreagem de pessoa que foi criada na letra ${ }^{41}$.

No caso de "Esse cara sou eu", temos tanto uma ilusão referencial (referência ao eu da enunciação) quanto uma ilusão enunciativa ( $e u$ que se refere a alguém do mundo que interpreta a canção). Primeiro, temos a ilusão de que o eu instaurado no enunciado e que é o narrador é também o enunciador desse texto. Depois, temos a ilusão de que esse eu narrador é o próprio intérprete "Roberto Carlos", que é o $e u$, no mundo natural. Parece, então, que a música é de quem está cantando, pois é como se o intérprete da canção estivesse falando com seu público, e as palavras que pronuncia fossem suas, os sentimentos expressos pelos versos fossem seus. Essa ilusão é causada por uma embreagem, que é independente daquela que pode ocorrer no interior da letra, pois há um retorno à enunciação de forma mais ampla, que excede ao texto. Isso pode ocorrer porque a voz da canção pode ser entendida como uma metonímia do intérprete (é parte do corpo físico de quem canta), e se mistura com a voz do enunciador e do narrador do texto. Como a voz do intérprete é um dos meios de manifestação da canção e, portanto, é um dos elementos do plano da expressão do texto, pode ocorrer essa mistura de "eus": eu enunciador, o autor-implícito do texto, o $e u$ narrador, o $e u$ ator do enunciado sincrético (parte verbal e parte gestual), e o $e u$ Roberto Carlos, que canta, que está fora do texto e que, portanto, só será analisado pela Semiótica se for entendido também como uma forma de expressão do $e u$ ator do enunciado ${ }^{42}$.

Outro exemplo da produção do efeito de uma ilusão enunciativa em um texto é a que ocorre também por uma embreagem temporal em textos fílmicos, seja no cinema ou em comerciais de TV, por exemplo, quando há flashbacks e o passado é presentificado. Segundo Fiorin (2008:20), as embreagens permitem essas voltas ao passado ou as idas ao futuro (flashfoward) ${ }^{43}$.

\footnotetext{
${ }^{40}$ As fotos do show "Reflexões" apresentadas neste trabalho foram feitas a partir do vídeo, que pode ser acessado em https://www.youtube.com/watch? $v=5 z$ Xrtc6LiTI\&feature=youtu.be. As fotos desse show, apresentadas nesta seção, foram feitas a partir desse vídeo. O vídeo encontra-se no DVD que acompanha esta tese na pasta "Outros textos analisados".

${ }^{41} \mathrm{Um}$ estudo sobre gestos que acompanham a fala que se tornou referência nos estudos da gestualidade foi feito por David McNeill. Em seus trabalhos, o autor descreve gestos icônicos, metafóricos, beats, coesivos e dêiticos (ver McNeill, 1992). Segundo o autor, fala e gesto podem expressar, juntos, os significados ou os sentidos do texto de uma pessoa (p.11). Um estudo sobre a gestualidade, no âmbito da semiótica greimasiana, pode ser lido em Barros (2010).

${ }^{42} \mathrm{O}$ material dessa análise da canção "Esse cara sou eu” foi transformado em um artigo (ver Moreira, 2014).

${ }^{43}$ Nas narrativas verbais, esses dois mecanismos de recuo ou antecipação dos fatos são chamados, respectivamente, de analepses e prolepses (ver Fiorin, 2008: 20).
} 
Ao analisar a construção do tempo em uma propaganda veiculada na TV aberta, em 2013, foi possível perceber esse efeito de sentido da ilusão enunciativa gerada por uma embreagem temporal. Trata-se do comercial do carro Fox da Volkswagen ${ }^{44}$. Nesse anúncio televisivo, os garotos-propaganda são os integrantes da banda de rock mineira Jota Quest, a mulher do vocalista da banda, Rogério Flausino, e uma amiga dela.

Na primeira cena da propaganda, há a despedida do casal. Logo em seguida, a mulher entra no carro, senta-se ao volante, ao lado da amiga, que faz o seguinte comentário: "Nossa, ser mulher de um vocalista de uma banda deve ser um máximo!”. As imagens desse momento estão registradas na figura 2 , a seguir.

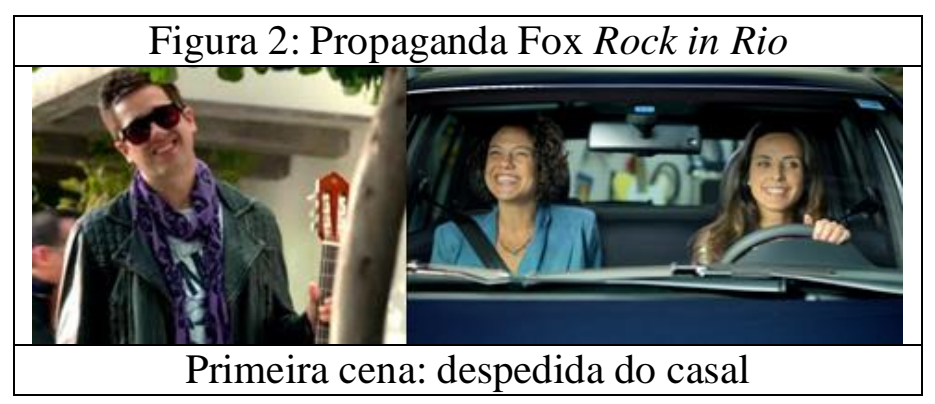

Logo depois desse momento, que aparece na figura 2 acima, a motorista olha para frente, aparentemente sem foco, e uma música se inicia ao fundo. O olhar instaura um novo espaço, que será associado a outro momento que será representado de forma diferente. Na figura 3, é possível observar o momento exato em que o olhar da mulher se volta para o horizonte.

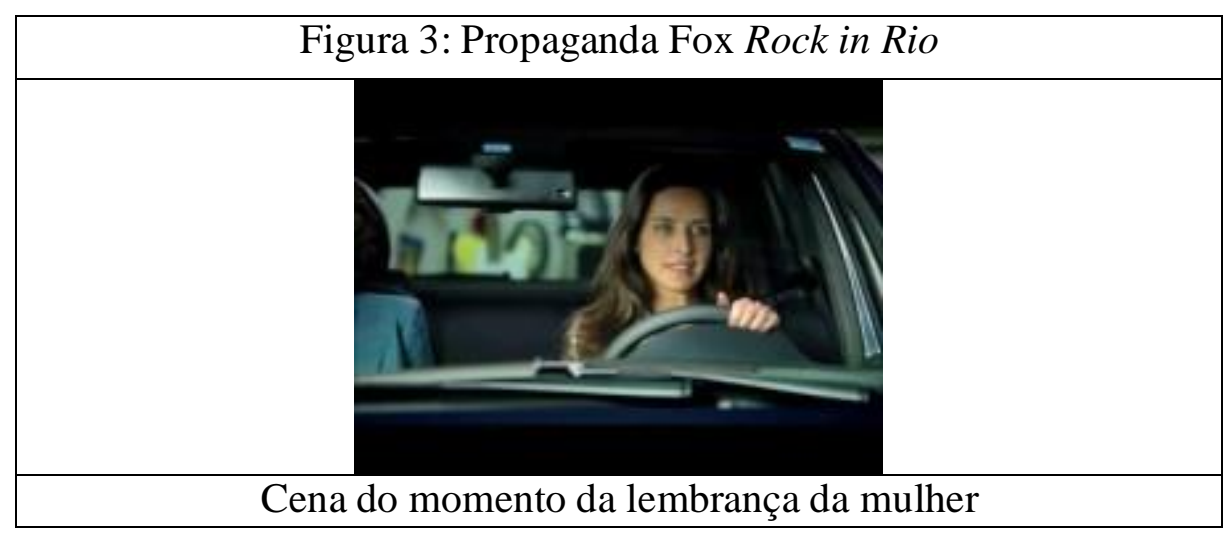

\footnotetext{
${ }^{44}$ Nesta propaganda, o Fox Rock in Rio é apresentado como o carro oficial do rock. Para assistir ao comercial, basta clicar no seguinte link: https://www.youtube.com/watch? $v=Q K N I E H h 56 x Q$. As fotos do comercial apresentadas neste trabalho foram feitas a partir desse vídeo, que também se encontra no DVD que acompanha esta tese, na pasta "Outros textos analisados".
} 
Junto com a música, algumas cenas começam a aparecer rapidamente, uma em seguida da outra, sem uma conexão lógica entre elas. São momentos típicos da rotina doméstica, da rotina a dois de um casal, de uma mãe que cuida de seu bebê. Em todas essas cenas, a motorista do carro vive ações que não são concomitantes ao primeiro momento da história, em que ela e sua amiga se preparam para sair de casa. São momentos anteriores, supostamente já vividos por ela, e dos quais está se lembrando, ou imaginando. São, portanto, pequenos flashbacks de seus momentos com o marido, com o filho, realizando suas tarefas diárias.

A volta ao passado é dada pela diferença de cenário, do figurino das personagens, pela própria sucessão de ações, a música que destoa do som da cena inicial do comercial, sem contar o pequeno esfumaçamento que ocorre no início dessa sequência de imagens que representam a lembrança ou a imaginação da mulher. A cor se modifica e a velocidade com que as cenas são apresentadas é maior do que a sequência inicial. Há uma alteração e uma aceleração no ritmo de apresentação dos fatos. Todos esses recursos, típicos da linguagem do cinema, ajudam a criar uma presentificação do passado, nesse texto do comercial.

Nas cenas da lembrança da motorista, todas as suas ações são realizadas na presença da banda inteira. Todos os integrantes do Jota Quest estão presentes nos momentos românticos do casal, em todos os cômodos da casa, e, de certa forma, até atrapalhando o casal e sendo, assim, anti-sujeitos, como se pode observar, na figura 4, a seguir, em um desses instantes, em que um dos músicos pega leite da mamadeira do bebê para colocar em sua tigela com cereais.

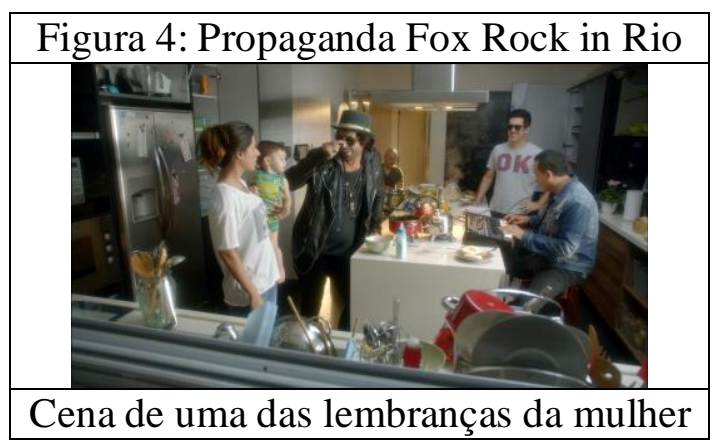

No final do comercial, voltamos à cena inicial, da motorista, dentro do carro, ao lado da amiga que continua sorrindo, e, pelas expressões faciais dela (certa insatisfação com a lembrança; olhos fechados; respiração profunda), como mostrado na figura 5, abaixo, percebemos sua sanção negativa, tanto a sua vida ao lado de um vocalista de banda de rock quanto ao comentário feito pela amiga anteriormente, no início da propaganda. Ela, no entanto, não verbaliza essa sanção à 
amiga, que, ao que parece, continua com a mesma ideia, dado o sorriso estampado em seu rosto até o final do comercial ${ }^{45}$.

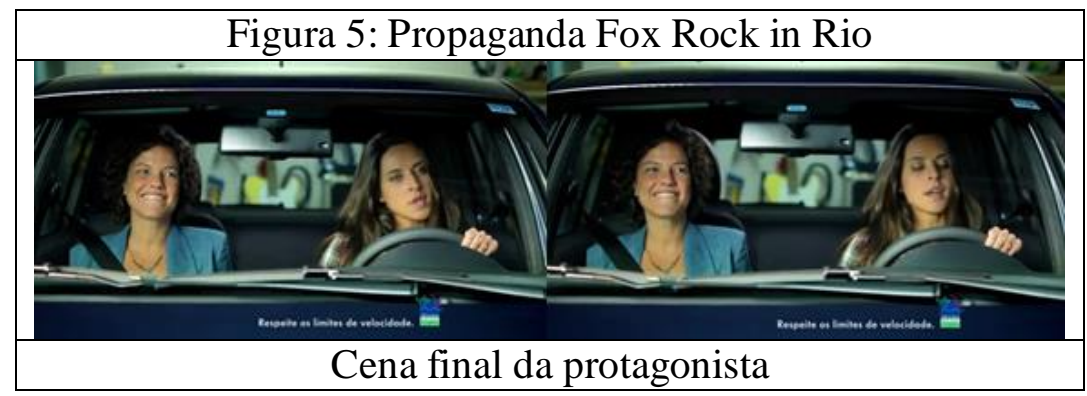

Essa propaganda do carro Fox, sem marcas iniciais explícitas de tempo, pode ser considerada um texto em que o sistema temporal principal, que organiza todas as relações internas no texto, é enunciativo, pois é como se a primeira cena, das duas amigas entrando no carro, estivesse acontecendo no presente, concomitante ao momento da enunciação. Não há marcas de uma não-concomitância inicial e, portanto, pode-se interpretar um presente implícito e que, houve, nesse texto, uma debreagem enunciativa do enunciado. As cenas que aparecem na sequência, entretanto, não estão nesse mesmo tempo do agora, mas sim, pertencem ao passado da motorista, são lembranças ou imaginações delas, portanto, não são concomitantes ao momento de referência que foi instaurado inicialmente no texto e também não são concomitantes ao momento da enunciação. Esse passado, no entanto, pertence ainda a um sistema enunciativo, pois ele é criado a partir de um ponto de referência presente.

A questão é que esse passado é presentificado nessa propaganda, como também ocorre nos flashbacks em filmes, por exemplo, em que as ações do passado aparecem como se estivessem no presente, rapidamente, para que se crie um efeito de aproximação, de verdade, de que aquilo de fato ocorreu, e para que o enunciatário consiga acessar o que está, em princípio, apenas nos pensamentos, lembranças, imaginações da personagem. Ocorre, portanto, nesses casos, uma embreagem de tempo, que possibilita que um passado tenha valor de presente, mesmo que seja por um tempo curto de apresentação. As marcas dessa embreagem estão, como já foi dito, na mudança do olhar da motorista e na forma como são apresentadas as cenas do passado, que são, dentro desse texto, indicadores espaciais. Essa alteração na direção do olhar da

\footnotetext{
${ }^{45}$ A propaganda, então, termina ao som de uma das músicas da banda, "Na moral", que reforça a ideia principal do texto de que o bom mesmo é ter o carro que está sendo anunciado! O Fox, sim, te fornece toda "moral" que você precisa e é "um máximo!", não ser esposa do vocalista de uma banda de rock, segundo o comercial.
} 
personagem será notada também nos textos em libras analisados nesta pesquisa. Neles, também há flashbacks e isso será mostrado mais adiante nesta tese.

Os filmes procuram marcar bem as concomitâncias temporais e a sucessividade dos fatos narrados, assim como também marcam, de alguma maneira, as discordâncias temporais: essas antecipações ou esses recuos no tempo. Os mecanismos de debreagem e embreagens responsáveis pela localização temporal são como aqueles que ocorrem em textos verbais, por exemplo, mas esses discursos podem contar com as várias substâncias que compõem seu plano de expressão para projetar no enunciado o tempo: expressões verbais, imagens, som, mudanças na cor e no formato das cenas, etc, para manifestar o tempo instaurado.

Para estudiosos do cinema, a linguagem cinematográfica consegue operar com o tempo de diferentes maneiras, criando nos textos fílmicos os mais variados efeitos de sentido. Segundo Silva (2004), o cinema é a arte do presente e, assim, divide a concomitância do narrado com a enunciação em três tempos: presente do presente, presente do passado e presente do futuro. As estratégias discursivas podem ser organizadas, segundo o autor, de forma sistematizada, e podem compreender, como em qualquer outro texto, a localização temporal, a programação temporal, a programação textual e a aspectualização ${ }^{46}$.

Como já foi dito, tanto a debreagem enunciativa da enunciação ou do enunciado como as embreagens enunciativas são mecanismos discursivos que geram efeitos de aproximação, de presença, de simulação da realidade em um texto, e podem, portanto, criar essa ilusão enunciativa que aparece na propaganda analisada. Entendemos que os acontecimentos são narrados nos tempos enunciativos, para criar um efeito de sentido de simultaneidade entre a narração e os eventos. É importante mencionar, entretanto, que a presentificação de um tempo passado ou de um tempo futuro, em um filme, por exemplo, caracteriza uma embreagem. No caso das embreagens temporais enunciativas, esse efeito de aproximação é mais forte e mais pontual no texto, além de ser bem marcado. Sabemos quando estamos diante de um flashback, ou de uma antecipação da história, embora, tenhamos a ilusão de que os fatos estão acontecendo no presente.

As debreagens enunciativas também podem gerar esse efeito de ilusão enunciativa, mas de um jeito diferente do que ocorre com as embreagens. Como a debreagem enunciativa de

\footnotetext{
${ }^{46}$ Para analisar o tempo no cinema, Silva (2009a e 2009b), primeiramente, diferencia a programação temporal da programação textual. Segundo o autor, a programação temporal é a ordem dos acontecimentos representada na diegese do filme. O que corresponderia às maneiras de ordenar os acontecimentos no cinema, como a simultaneização, sucessão e inversão dos fatos narrados. A programação textual é a organização do próprio texto. Toda organização temporal é marcada por meio de formas gramaticais e pelo estabelecimento das relações internas do texto. Essa organização pode se dar de três maneiras: por identidade, por expansão e por condensação.
} 
tempo permite que se coloque o $\mathrm{ME}$, dentro do discurso, em qualquer ponto do tempo cronológico, é possível que, em um filme, por exemplo, um evento seja apresentado como sendo concomitante ao momento da enunciação, como se estivesse acontecendo no agora, e, portanto, apresentado sem marcas de não-concomitância com o presente. Nesse caso, não ocorre uma presentificação do passado, mas sim, nos termos de Silva (2004), um "presente do passado". Nos textos em que isso ocorre, há a criação de um simulacro quase que perfeito do mundo natural e não há marcas claras de que se trata de um tempo do então, como acontece na embreagem ${ }^{47}$.

Em textos cuja debreagem de tempo é enunciva (ou seja, quando são projetadas no enunciado as categorias de não agora), também podem ocorrer ilusões enunciativas. Pode-se, por exemplo, atribuir a algo ocorrido no tempo do então uma figurativização de presente, e criar uma ideia de que aquilo que está sendo apresentado como já tendo ocorrido estivesse ocorrendo naquele momento em que é representado para o espectador, no tempo em que uma propaganda, por exemplo, está passando e sendo vista no mundo físico e real. Novamente, não se trata de uma presentificação do passado, mas sim, da construção de um "presente do passado".

A ilusão enunciativa de tempo presente na propaganda do FOX também pode ser observada em um anúncio televisivo sobre o Chocotone da Bauducco. Nesse texto, esse efeito de sentido é gerado tanto por uma debreagem quanto por uma embreagem de tempo ${ }^{48}$. Esse anúncio conta com um texto verbal, que é a voz que narra ao fundo, com música que acompanha as cenas, e um plano visual que apresenta um homem como personagem, experimentando um Chocotone.

Na figura 6, aparecem as cenas do início do comercial, ainda sem a narração ao fundo. Nesse momento, nota-se a apresentação do ator do enunciado, que pega um pedaço de Chocotone e o experimenta. Como na propaganda do carro FOX, não há, nessas primeiras imagens, um marcador temporal explícito. Por não haver uma marca de não-concomitância com o ME, podemos considerar que se trata de um tempo enunciativo, um presente implícito novamente, e que há uma ilusão de proximidade gerada por uma debreagem enunciativa temporal. Novamente, temos um "presente do presente".

\footnotetext{
${ }^{47}$ Seguindo as ideias de Bertinetto (1986: 334, citado em Fiorin, 2002: 207), seria possível dizer que essa aproximação gerada pela debreagem enunciativa pode ser comparada ao efeito de zoom do cinema (ver Bertinetto, P. M.Tempo, aspetto e azione nel verbo italiano. Il sistema dell'indicativo. Florença, Academia della Crusca, 1986).

${ }^{48}$ A propaganda Bauducco-Lembranças está disponível pelo link: https://www.youtube.com/watch?v=2maRudzhHEE. As fotos apresentadas nesta seção foram feitas a partir desse vídeo, que se encontra no DVD que acompanha esta tese, na pasta "Outros textos analisados".
} 


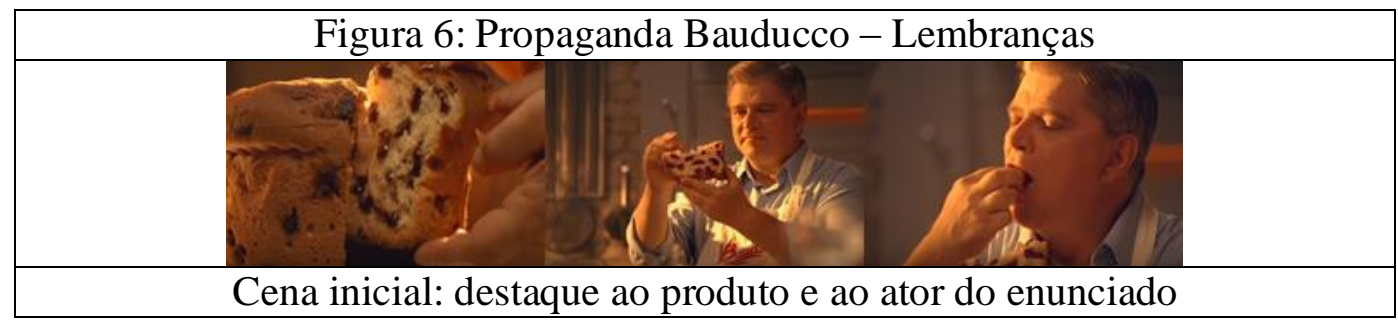

A narração verbal que acompanha as cenas é composta por um enunciado organizado a partir de um MR presente. Nele é instaurada a primeira pessoa, eu, e um tempo enunciativo, no verbo da oração principal: "Eu lembro bem a primeira vez que vi meu pai fazendo Chocotone". Na figura 7, a seguir, é possível ver o momento em que essa narração se inicia e o instante em que a personagem, ao se lembrar do tempo em que era menino e aprendeu os segredos culinários de sua família, muda sua expressão facial e a direção de seu olhar.

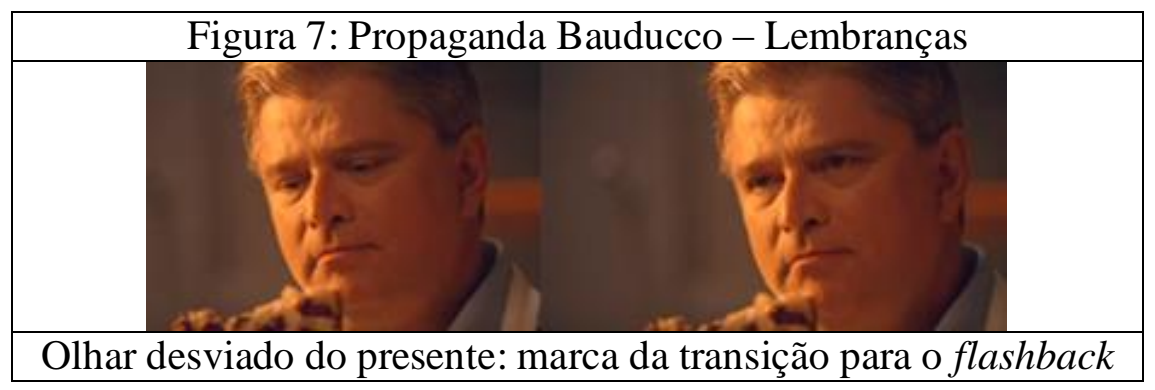

Como na propaganda do FOX, a personagem da propaganda da Bauducco também olha para o horizonte, aparentemente sem foco, antes de aparecerem cenas que se reportam ao passado dela. As cenas que sucedem a essa mudança do olhar não se encontram no mesmo tempo instaurado no início do texto (presente). As ações que não são concomitantes com o agora são acompanhadas da narração e coincidem com o momento em que o narrador diz a segunda parte da oração ("a primeira vez que vi meu pai fazendo Chocotone”). As cenas, então, ficam em preto e branco, marcando claramente esse flashback, como é possível ver na figura 8, a seguir.

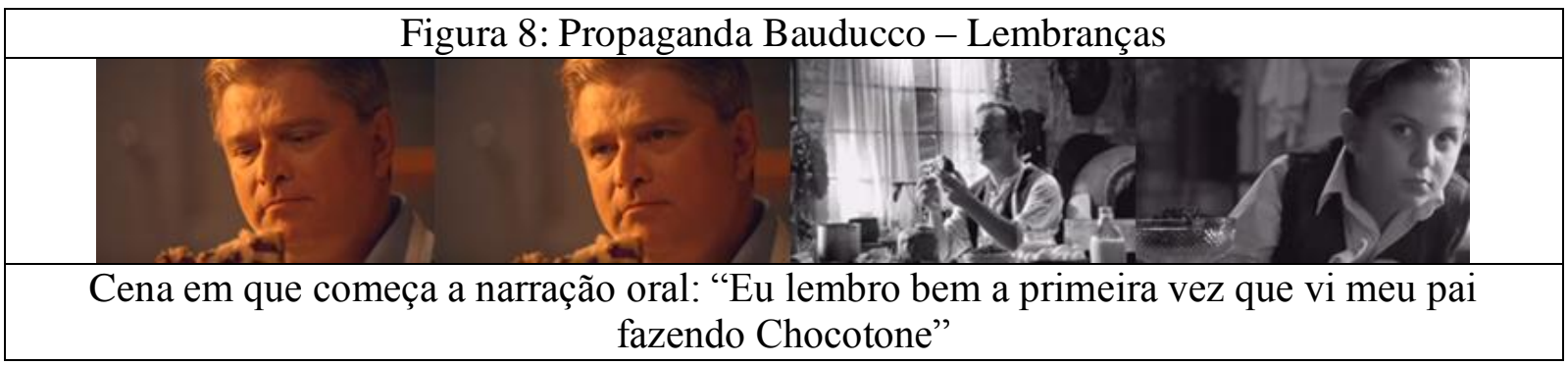


Na figura 8, acima, a primeira imagem representa o momento exato em que o narrador começa a narrar e o flashback é instaurado. Nas imagens, uma série de mudanças acontece, depois que a personagem desviou o seu olhar do que estava comendo. No lugar do homem do início do comercial aparece outro, seu pai e, em seguida, ele mesmo pequeno. A identidade entre as figuras discursivas, o sujeito do começo e o menino do tempo passado, expressas pela parte visual do plano de expressão, é criada pelo texto verbal. A categoria de pessoa $e u$ recobre tanto o actante do presente quanto o actante do passado. O eu narrador não é o sujeito que aparece mais velho, no passado, mas sim, o menino que está aprendendo a técnica de fazer Chocotone. Também é por meio do verbal que há um sincretismo do narrador do texto e o ator do enunciado.

No flashback, o narrador aparece pequeno, também como ator do enunciado, olhando para seu pai. Nesses instantes em preto e branco, a narrativa oral segue com os verbos da oração subordinada no tempo passado: pretérito perfeito 2 (tempo enuncivo, que marca a nãoconcomitância daquelas ações com o presente da enunciação), ou seja, na parte verbal, o tempo é instaurado por uma debreagem enunciva, pois se organiza a partir de um MR passado ("a primeira vez"). Como se trata de um texto sincrético, a parte visual também oferece pistas dessa diferença temporal, com as mudanças cromáticas das imagens, por exemplo. Sabemos que se trata de outro tempo, diferente do MR instaurado logo no início do texto, porque as imagens perdem a cor original, o ator do enunciado é outro e, embora, o espaço pareça o mesmo, há elementos que compõem o cenário que apontam para outra época, não garantindo que as personagens do hoje ou do ontem estejam no mesmo local.

Quando o texto retorna do passado para o tempo em que começou a narrativa, temos o sujeito do enunciado inicial interagindo com seu filho e, passando, como fizera seu pai, no passado, os segredos de família de como fazer esse tipo de Chocotone anunciado. O texto termina com o texto verbal que diz "na nossa família, um gesto ensina mais que palavras", com as imagens que retomam suas cores iniciais, como aparecem na figura 9, abaixo.

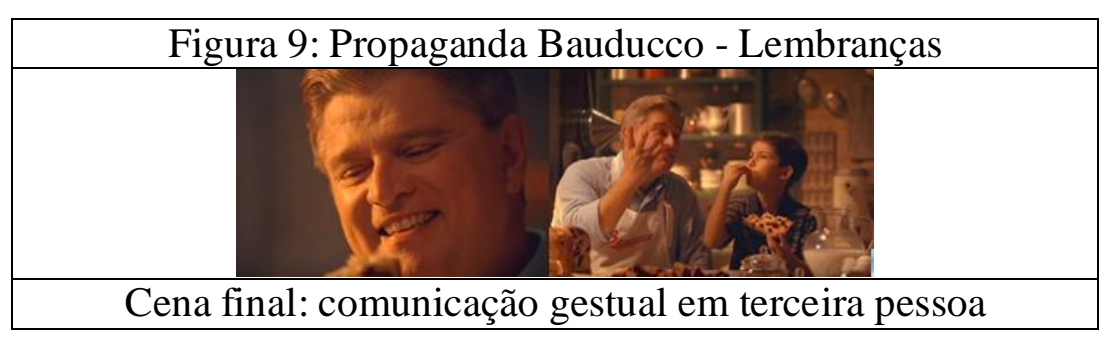


$\mathrm{Na}$ parte visual de todo o comercial, o espaço e as pessoas são construídos como categorias enuncivas, embora o tempo, como já foi mostrado, seja enunciativo. As imagens da figura 9, acima, por exemplo, mostram uma gestualidade de anúncios tipicamente de terceira pessoa. Há, na propaganda da Bauducco, tanto a representação de uma práxis quanto de uma comunicação gestual que, no nível do enunciado, devem ser analisadas como uma narrativa nos termos de Greimas (1979) ${ }^{49}$. Inicialmente, no texto, aparece o ator do enunciado experimentando um Chocotone, o que pode ser entendido como um investimento figurativo das transformações narrativas desse sujeito (no final da propaganda fica claro que foi ele quem fez o doce, porque aprendeu com seu pai, e, hoje, ensina para seu filho). No momento do flashback e no final do comercial, é representada, nas imagens, uma comunicação gestual, em que as relações de comunicação de pai e filho se tornam as figuras do discurso. Também se trata de uma comunicação gestual em terceira pessoa. Há, no entanto, em toda a propaganda, uma presença grande de elementos discursivos enunciativos, como o detalhe do Chocotone, o prazer do homem que pega um pedaço dele e o experimenta. Esse processo de triagem, de detalhamento da cena nos aproxima daquilo que, em princípio, seria distanciado (terceira pessoa). Isso é reforçado pelo tempo presente, na parte verbal da propaganda.

No nível da enunciação, a gestualidade apresentada no texto também pode ser analisada como sendo em terceira pessoa. Não há uma gesticulação de "indicar" ou "mostrar", como apontamentos com os dedos, olhar voltado para o enunciatário/narratário, porque não se trata de uma gestualidade do nível do enunciador/narrador e enunciatário/narratário, como descreve Barros (2010) em alguns anúncios de bancos analisados, em seu artigo. A gestualidade representada no enunciado, no entanto, também revela, pelo gestual do ator, suas emoções, paixões, sentimentos, o bem-estar por estar experimentando algo gostoso, a nostalgia e felicidade ao lembrar como aprendeu a fazer isso. Essa representação do estado passional da personagem também gera um efeito de proximidade.

Diferentemente, na parte verbal do anúncio, a narração simultânea às imagens, cria uma comunicação diferente e instaura categorias enunciativas. Quando as imagens em preto e branco são apresentadas, marcando a ocorrência de um flashback no texto, há uma presentificação do passado, e, portanto, um efeito de ilusão enunciativa também é gerado nesse texto, aproximando enunciador e enunciatário, e reforçando essa comunicação já estabelecida pela narração oral que

\footnotetext{
${ }^{49}$ Segundo Barros (2010: 05) a gestualidade que é representada em um texto tem funções diferentes de acordo com o tipo que foi empregado (práxis gestual ou comunicação gestual) e os níveis de análise da semiótica (da enunciação ou do enunciado).
} 
acompanha as cenas do comercial. Ocorre, nesse texto, no momento do recuo ao passado, portanto, uma embreagem temporal. As pistas da neutralização do tempo enuncivo com o tempo enunciativo, que mostram que o passado está sendo usado com valor de presente, estão principalmente na mudança de cor das cenas, juntamente com outras substâncias que compõe o plano da expressão desse texto, como a música, a luz e o enquadramentos, etc.

Todo enunciador estabelece, no interior do texto, um sistema lógico de sucessão e concatenação de fatos e torna convencionais, no plano da expressão e no plano de conteúdo, as formas de representar as diferenças entre os momentos de acontecimento de uma história. No filme Blue Jasmine, escrito e dirigido por Woody Allen, em 2013, por exemplo, um recurso bastante explorado é o da mudança de espaço usada para marcar os recuos temporais.

No início do filme, não temos qualquer ancoragem temporal, então, logo entendemos como um presente implícito, que equivale ao presente do enunciatário também, o presente da enunciação. Mas, logo nos primeiros minutos de história, ocorre o primeiro flashback do filme. Para quem assiste, esse deslocamento temporal é bastante confuso, porque não há ancoragem verbal dessa mudança, não sabemos para que tempo vamos do passado, só entendemos que não é o tempo em que o filme começou a ser narrado, porque o cenário muda, e a personagem está interagindo em outro espaço, com outras personagens, vestida de forma diferente. Os flashbacks seguintes do filme ocorrem da mesma maneira: com essa mudança do espaço da ação, que nos reporta a momentos em que a personagem ainda era casada. Depois do primeiro flashback, entendemos perfeitamente o mecanismo que o filme criou para fazer esses deslocamentos temporais e presentificar o que era passado.

Ao assistirmos a um filme ou a uma propaganda na televisão, então, temos exemplos de textos que "brincam" com as relações temporais, usam e abusam desses mecanismos discursivos de debreagem e embreagem, que, no interior do discurso, criam efeitos de sentido muito interessantes: o passado e o futuro, por exemplo, podem se deslocar para o presente na enunciação do texto e acontecerem diante dos nossos olhos de enunciatário, como se as ações narradas fossem concomitantes à própria ação de assistir a esses textos. Como foi mostrado, por um período de tempo da narração, a diferença temporal, e tudo pode parecer presente. Neutralizase, assim, o que veio antes ou o que vem depois. O que temos, então, é uma ilusão de que tudo é enunciativo: tudo a que assistimos está acontecendo agora, no presente do espectador do texto. Esse mesmo efeito ilusório, criado pela embreagem de tempo e por debreagens enunciativas, de primeiro e de segundo grau, nos discursos fílmicos ou de comerciais, como o do carro FOX e do 
Chocotone da Bauducco, por exemplo, também pode ser verificado em alguns textos em libras selecionados para esse trabalho, como será mostrado no capítulo 4.

\section{5) Considerações finais do capítulo}

Neste capítulo, o objetivo foi sintetizar os princípios teóricos dos quais este trabalho parte para realizar o estudo do tempo nos discursos em libras. Primeiramente, apresentei os conceitos de enunciação e tempo linguístico e, em seguida, uma explicação sobre os mecanismos de instaurar as categorias discursivas de pessoa, espaço e tempo. Destaquei as embreagens de tempo e seus efeitos de sentido em diferentes textos, em especial, o efeito de ilusão enunciativa.

A semiótica greimasiana oferece um aparato teórico-metodológico que nos ajuda a entender a construção dos sentidos dos discursos que produzimos, descrevendo cada elemento que compõe toda essa estruturação do texto e entendendo como cada um deles se relaciona e contribui com os efeitos de sentidos que são criados nos enunciados. Por ser uma teoria que se especializou no estudo de diferentes tipos de textos e descreveu diferentes formas de se expressar o conteúdo, a Semiótica parece estar preparada para olhar também para as línguas de sinais, que vão apresentar textos diferentes dos que vêm sendo estudados até pouco tempo pela Linguística e que trazem para o centro das discussões os gestos como a forma de manifestação dos textos dessas línguas. 


\section{Capítulo 2}

\section{As línguas de sinais e o tempo}

“Não posso ouvir mas posso ver a chuva cair colorida!” (Vergamini, 2003)

Chuva colorida - Mãos Fazendo História

Alexandre Jurado Melendez

Neste capítulo, o objetivo é apresentar e discutir alguns estudos sobre o tempo em línguas de sinais, destacando aqueles que, de alguma forma, contribuíram com o desenvolvimento desta pesquisa, por apresentar tanto resultados que podem corroborar o que foi descrito sobre a marcação de tempo em libras, e confirmar algumas hipóteses iniciais deste trabalho, quanto suscitar alguns questionamentos que fizeram com que o estudo que apresento nesta tese avançasse na descrição proposta e levantasse novas questões de investigação. Encerro esta seção, mostrando uma nova maneira de entender a manifestação temporal em libras, que será mais bem desenvolvida no capítulo 4.

2.1) Os estudos linguísticos sobre as línguas de sinais

O trabalho de Stokoe (1960) é considerado um marco nos estudos das línguas de sinais, porque foi com essa primeira descrição da gramática da língua de sinais americana (ASL) que as línguas sinalizadas deixaram de ser vistas como um tipo de linguagem criada pelo homem, um mero conjunto de mímicas, com gestos universais, usados por comunidades surdas de diferentes partes do mundo, e foram consideradas também línguas naturais (Wilcox \& Wilcox, 2005). A partir disso, mudanças significativas ocorreram na vida dos surdos, que passaram a ter uma identidade social, e nos estudos linguísticos de um modo geral. Com a pesquisa pioneira de Stokoe e, em seguida, os estudos de Klima \& Bellugi (1979), não foi mais possível ignorar que as línguas de sinais, como qualquer outra língua humana, emergem naturalmente, são diferentes conforme à cultura a qual pertencem, possuem um sistema linguístico organizado e a capacidade de criar diferentes textos. 
Uma das maiores contribuições de Stokoe foi a descrição fonológica da ASL. O autor demostrou que, como as palavras das línguas orais, os sinais também possuem propriedades articulatórias regidas por regras e são constituídos de um número finito de partes que podem ser combinadas e recombinadas ilimitadamente. Os sinais foram divididos em três aspectos ou parâmetros: localização, configuração de mão (forma que a(s) mão(s) assume(m) na realização do sinal) e movimento. Mais tarde, foram por ele acrescentados a esses parâmetros a orientação das mãos e as expressões faciais que acompanham alguns sinais

Depois de Stokoe (1960), muitos estudos linguísticos sobre as diferentes línguas de sinais surgiram em todo o mundo. Esses trabalhos não se concentraram, no entanto, apenas na fonologia. Eles avançaram em todos os níveis de análise e os pesquisadores vêm mostrando também propriedades morfológicas, sintáticas, semânticas, pragmáticas e discursivas das línguas sinalizadas. Inicialmente, boa parte dessas pesquisas procurou mostrar apenas as características gramaticais e discursivas comuns entre as línguas de sinais e as línguas orais, sem colocar em questão os pressupostos e paradigmas já estabelecidos na ciência linguística para as línguas orais.

Stokoe (1979), no entanto, foi também o primeiro a chamar a atenção para as características visuais das línguas de sinais e, partindo das ideias de Hockett (1979), argumentou que há diferenças significativas na forma de essas línguas arranjarem os seus signos, organizarem os seus enunciados, expressar as suas relações dêiticas, as suas relações sintáticas e os seus significados. O uso do corpo todo, não só das mãos, e todo o espaço de sinalização em frente e ao redor dele possibilitam a realização de uma língua que possui possibilidades ainda não exploradas nos estudos tradicionais. Para reforçar essa ideia, Stokoe cita o trabalho de Liddell (1978), que mostrou que certos movimentos da cabeça e detalhes na face do sinalizador, por exemplo, como movimento de sobrancelhas, boca, etc., que acompanham os enunciados, podem indicar relações sintáticas. Outras características como apontamentos no espaço, simultaneidade de sinais, movimentos do corpo para expressar ações também foram apontadas pelos autores e mostraram particularidades dessas línguas visuais-gestuais que não poderiam mais ser ignoradas. A Linguística Moderna precisou, então, ampliar seu objeto de estudo e olhar para as línguas de sinais e para tudo que elas estavam trazendo de novo e diferente sobre a gramática e o discurso das línguas naturais. Mais curioso ainda é que, com essa abertura para as diferenças, a Linguística também pôde se voltar para as línguas orais com um novo olhar e ampliar seu campo de estudo com mais pesquisas sobre os gestos que acompanham a fala, por exemplo.

Também são necessário, segundo Barros (2010: 13), estudos semióticos sobre a gestualidade, "pois a gesticulação humana constrói o homem enquanto sujeito das ações de 
transformação do mundo e, sobretudo, cria a vida em sociedade, isto é, as relações corporais e passionais" que ligam os seres humanos. Para McCleary \& Viotti (2011), a parceria entre fala e gesto, em situações de uso, nas línguas orais, não pode mais ser negada por quem estuda os discursos dessas línguas. No caso das línguas de sinais, ignorar sua gestualidade é ainda mais grave. Para os autores, não olhar para os gestos é também ignorar as particularidades linguísticas de uma língua que pertence a outra modalidade ${ }^{50}$.

O estatuto do gesto na gramática e no discurso das línguas de sinais, no entanto, não é uma questão trivial, nem para a comunidade surda nem dentro da literatura sobre essas línguas. Por muito tempo, os surdos lutaram contra a ideia de que, em sua língua, houvesse gestos. Isso representava uma reação a um entendimento errado que havia no passado de que as línguas de sinais não eram línguas naturais, mas sim, um conjunto de mímicas, uma linguagem universal Nos estudos linguísticos, isso não foi muito diferente. Ainda não há um consenso sobre o papel do gesto entre os pesquisadores das línguas sinalizadas.

Segundo Liddell (2003), inicialmente, poucos estudos se preocuparam com a gestualidade presente nas línguas de sinais, como as pantomimas, por exemplo ${ }^{51}$. Para o autor, os gestos fazem parte da gramática das línguas sinalizadas, mas precisam ser diferenciados do que é propriamente linguístico em sua concepção. Segundo ele, o uso do espaço de sinalização envolve uma integração de gramática, gesto e um processo de construção de significados por meio de espaços mentais. Para alguns estudiosos, como Sherman Wilcox, os gestos têm uma importância maior na constituição dessas línguas e podem ser entendidos como parte delas. Para ele, gesto é língua. Para outros linguistas como McCleary \& Viotti (2010, 2011 e 2014), gesto e língua se unem e se misturam, na construção dos textos das línguas de sinais. Para eles, a distinção do que é propriamente sinal e o que é propriamente gesto não está clara ${ }^{52}$.

\footnotetext{
${ }^{50}$ Os autores chamam a atenção para o fato de os estudos sobre gestos terem se iniciado primeiramente nas línguas orais e de essas pesquisas recentes terem mudado a maneira de entender, não só a gramática de línguas como a libras, mas também o próprio conceito de língua natural e a própria ciência linguística.

${ }^{51}$ Como, tradicionalmente, a linguística deixa de lado o estudo dos gestos que acompanham a fala, quando se começou a olhar para as línguas de sinais, todos os elementos gestuais foram ignorados ou tratados como uma mesma coisa: pantomimas, por exemplo.

${ }^{52}$ Os trabalhos de McCleary \& Viotti (2010, 2011 e 2014) têm se mostrado um avanço, não só nos estudos sobre a libras e sobre as línguas de sinais de um modo geral, como também no estudo sobre os gestos nas línguas orais. Trabalhos que seguem essas ideias, como Leite (2008), Bolgueroni (2013) e Silva (2014) reforçam as ideias desenvolvidas pelos autores.
} 
Embora muitos trabalhos descritivos sobre as línguas de sinais, hoje, não ignorem mais as suas especificidades visuais ou até considerem a gestualidade como um aspecto importante dos textos sinalizados, há ainda os que continuam procurando aspectos comuns dessas línguas com as línguas orais, muitas vezes, propondo uma estruturação gramatical, morfológica que não parece condizer muito com a modalidade visual. Um exemplo é o estudo de Felipe de Souza (1998).

Baseada em pesquisas como de Padden (1983), Lillo-Martin (1986 e 2001), Lillo-Martin \& Klima (1990), Meir (2002), Felipe de Souza apresenta uma tipologia dos verbos em libras, que se divide basicamente em duas classes principais: a dos verbos que apresentam flexão zero, ou seja, em que não há nenhum morfema de concordância associado a eles, e, por isso, precisa do auxílio de um pronome da língua em sua realização, e a outra, a dos chamados verbos indicadores ou direcionais, como ficaram mais conhecidos na literatura sobre as línguas de sinais, que, segundo Felipe de Souza, apresentam flexão de número e pessoa. Nessa visão, os pontos de articulação (início e fim do movimento) desses sinais são considerados um tipo de morfema ${ }^{53}$.

Em libras, o sinal PERGUNTAR é considerado um verbo indicador. Ele pode ser realizado de duas formas, como mostrado na figura 10, abaixo. O sinal recebe o nome PERGUNTAR, quando parte do peito de quem sinaliza e aponta para algum lugar no espaço associado ao referente a quem é feita a pergunta, e PERGUNTAR-ME, quando aponta para o peito do sinalizado. Em geral, o início do movimento, nesse caso, vai depender do discurso, do lugar, no espaço de sinalização, associado a quem fez a pergunta.

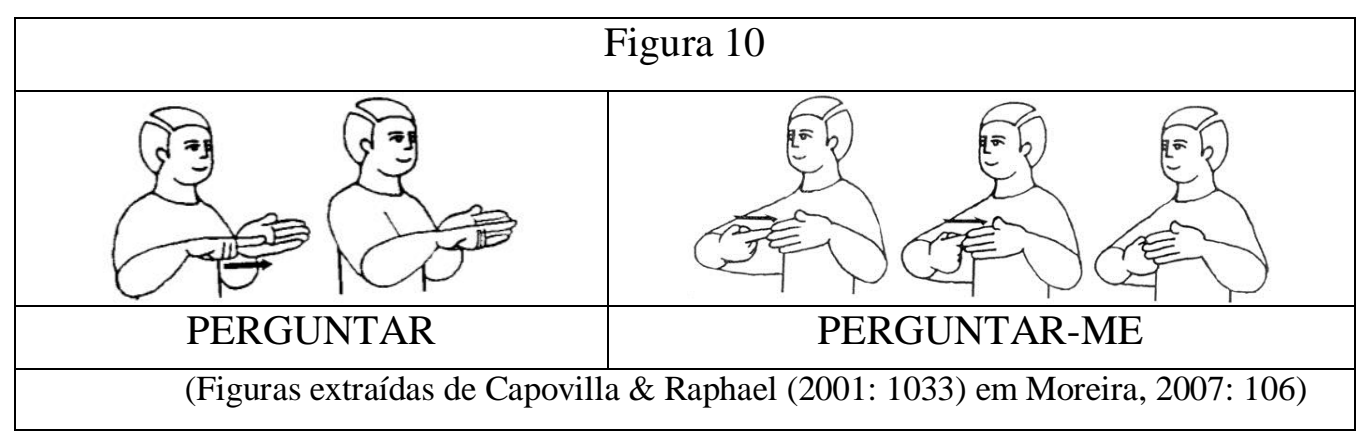

Liddell (2003) contrariou toda essa literatura tradicional, ao descrever o comportamento de pronomes e verbos indicadores da ASL e mostrar que eles são dêiticos, e não capazes de

\footnotetext{
${ }^{53}$ Dentro dessa visão mais tradicional sobre os verbos indicadores, esses pontos de deslocamento do verbo podem estar associados a locais, no espaço de sinalização, que estão sempre relacionados à primeira, à segunda, ou à terceira pessoas do discurso. Assim, quando um verbo indicador como PERGUNTAR se desloca no espaço de sinalização, partindo do corpo do sinalizador, o ponto de partida dele será interpretado como um morfema de concordância de primeira pessoa, que indica o sujeito desse verbo. O ponto de chegada do verbo indicará o objeto desse verbo.
} 
realizar concordância de pessoa. Há estudos que, como Liddell (1995, 2003), não veem a marcação de pessoa realizada por pronomes ou verbos indicadores como sendo concordância, e nem o apontamento e localização desses sinais como sendo morfemas flexionais (ver, por exemplo, Meier, 1990, Cormier, Schembri \& Woll, 2013). Para o autor, esses dois sinais de apontamento possuem uma parte linguística, que é invariável, e outra, que varia conforme a situação discursiva, pois têm a propriedade de se localizar ou de se mover no espaço físico em frente e ao redor do corpo do sinalizador, para apontar, dentro desse espaço, um local que está associado, no discurso, a uma representação mental do(s) seu(s) referente(s) ${ }^{54}$. Na concepção do autor, se os pontos de articulação dos pronomes e verbos indicadores fossem morfemas flexionais, eles teriam de ser sempre iguais. Mas não é isso que acontece. A direção do apontamento e movimento desses sinais são altamente variáveis ${ }^{55}$.

Para Liddell (1995), a gramática não é capaz de manipular um número ilimitado de morfemas para marcar algo específico em uma língua, e, tampouco, uma alomorfia ilimitada de um mesmo elemento gramatical, com forma indeterminada, sem um condicionamento linguístico propriamente dito. Para ele, é preciso rever essa ideia de tratar fenômenos espaciais das línguas sinalizadas como sendo morfemas ou mudar a sua definição linguística, para que fosse possível aceitar essa análise tradicional sobre os verbos, por exemplo. Na visão de Liddell, olhar para as línguas de sinais, sem ignorar suas características visuais e o papel dos gestos na composição de sua gramática e seu discurso, é de fato assumir uma nova postura linguística e se abrir para novas propostas, nem que elas contrariem certos pressupostos teóricos e metodológicos consolidados.

Para a semiótica greimasiana, os textos das línguas de sinais são entendidos como sendo textos gestuais e isso não parece ser uma questão polêmica ${ }^{56}$. A teoria analisa o plano do

\footnotetext{
${ }^{54}$ Essas entidades às quais os sinais dêiticos se referem são representadas espacialmente e estão sempre, de alguma maneira, "presentes" no discurso, podendo ser, assim, sempre apontadas fisicamente por esses sinais. Mesmo quando a entidade referida não está presente fisicamente, ela pode ser apontada, porque, da forma como é representada conceitualmente no discurso em língua de sinais, é localizada no espaço de sinalização e pode ser apontada por um sinal dêitico.

${ }^{55}$ Segundo Liddell (2003), os apontamentos realizados pelos pronomes e pelos verbos indicadores não se restringem ao espaço de sinalização e não são dirigidos sempre a posições fixas que correspondem à segunda ou terceira pessoas. Além disso, os verbos indicadores possuem a característica de alterar a altura de seu ponto de articulação, conforme a posição do referente à que se refere. Moreira (2007) mostra que o verbo PERGUNTAR, no texto em libras analisado, ora aponta para cima, ora para baixo, conforme a posição em que se encontra a personagem da história a quem é feita a pergunta.

${ }^{56}$ Considerar as línguas de sinais como línguas que possuem um plano de expressão gestual não é um problema para a Semiótica, embora, Greimas (1979: 43) tenha considerado, mesmo que provisoriamente, nesse artigo, a gestualidade como um sistema simbólico e não linguístico, seguindo a terminologia de Louis Hjelmslev.
} 
conteúdo de diferentes tipos de discursos, manifestados de diferentes modos, com planos de expressão das mais variadas formas. A forma como a semiótica olha para os gestos também não dificulta o estudo das línguas de sinais. Em um estudo sobre os sentidos da gestualidade, Barros (2010) propõe caminhos semióticos para o entendimento das transposições gestuais, entre elas, as línguas de sinais ${ }^{57}$.

Segundo Barros (2010: 13), nas línguas sinalizadas, ocorre uma passagem do gesto ao signo, ou, em outros termos, de uma semiótica do mundo natural a uma semiótica da língua natural. Os gestos que compõe a forma da expressão do mundo natural e se transformam em categorias da forma de conteúdo, no nível discursivo, que compreende a dimensão figurativa dos textos de uma língua. Para a autora, é preciso considerar, ainda, uma transposição de "iconização do plano da expressão" das línguas sinalizadas, uma vez que elas são visuais. A iconização e as pantomimnas seriam responsáveis por criar, segundo Barros, as relações de semelhança entre a gestualidade do mundo com a gestualidade expressa na língua, por meio de "onomatopeias visuais" ou signos icônicos. A autora também reforça que essas particularidades das línguas de sinais precisam ser mais bem examinadas linguística e semioticamente.

Como já foi dito, a semiótica vai estudar a organização interna do plano do conteúdo de todo e qualquer texto por meio dos mesmos princípios teórico-metodológicos. Para essa teoria, os discursos sinalizados também são estruturados temporalmente, por exemplo, mas as maneiras de localizar os eventos no discurso também são, como tantos outros elementos gramaticais dessas línguas, próprias de sua modalidade linguística e, portanto, será preciso um olhar mais amplo para o que é marca formal nessa língua. Como a libras conta com o corpo (tronco, ombros e cabeça), mãos, expressões faciais e o espaço ao redor do corpo para construir seus enunciados, será, também, dessa forma, que ela expressará suas relações temporais. Como todos os elementos presentes na língua são produzidos por gestos, manuais ou não-manuais, então, as marcas de tempo também serão feitas por gestos. Este trabalho, portanto, considerará toda a gestualidade na investigação dos modos de instaurar o tempo em libras.

\footnotetext{
${ }^{57}$ Partindo da distinção feita por Greimas (1979) entre "práxis gestual" e "comunicação gestual", Barros (2010) apresenta, em seu artigo, primeiramente, as questões teóricas que envolvem o entendimento da gestualidade poética da dança-espetáculo, dos tratamentos de fisioterapia e das línguas sinalizadas. Em seguida, apresenta uma análise sobre a representação da comunicação gestual entre destinador e destinatário em textos de anúncios publicitários de bancos.
} 
2.2) O estudo sobre o tempo nas línguas de sinais

Há muitos trabalhos sobre o tempo em diferentes línguas de sinais do mundo e todos eles reforçam essa ideia de que as línguas sinalizadas contam com marcadores de tempo típicos de sua modalidade visual e que, por isso, são variados. Há estudos sobre o tempo na língua de sinais americana (Friedman, 1975; Alkoby, s/d), na língua de sinais belgo-francesa (Sinte, 2013), na língua de sinais australiana (Johnston \& Schembri, 2007), na língua de sinais israelense (Meir\&Sandler, 2008), na língua de sinais mexicana (Mintz, 2005), na língua de sinais portuguesa (Amaral, Coutinho \& Martins, 1994), e também em libras, como já foi dito, com o trabalho de Finau (2004). Esses estudos foram realizados em outras perspectivas teóricas, como a gramática gerativa ou a linguística cognitiva, mas também serviram de ponto de partida para descrição sobre o tempo que apresento no capítulo 4.

Desses estudos, destaco os trabalhos de Alkoby (s/d), Johnston \& Schembri (2007), Sinte (2013) e Finau (2004), que apontam formas que as línguas de sinais que eles estudaram têm de instaurar o tempo em seus discursos. Na próxima seção, comento os resultados a que esses autores chegaram com suas pesquisas e as hipóteses que levantam, para poder apresentar uma discussão a respeito deles e, então, examinar a maneira como são construídas as relações temporais nos textos em libras que foram selecionados para esta pesquisa.

\subsection{1) Os marcadores e a linha do tempo}

Karen Alkoby (s/d) analisou dados da língua de sinais americana (ASL) e, em seu artigo intitulado A survey of ASL tenses, identifica como marcadores de tempo basicamente gestos manuais, que são itens lexicais que indicam tempo (advérbios), e itens lexicais não específicos de tempo, que, localizados no espaço, em algumas situações, podem estar envolvidos com as relações temporais. Além disso, há, segundo essa literatura, marcadores não manuais, como expressões faciais e movimento do corpo. Alkoby chama todas essas formas de marcar o tempo de sintagmas de tempo e, seguindo uma proposta gerativista, postula uma posição para eles em uma árvore sintática. Segundo a autora, a ASL expressa suas informações de tempo com esse conjunto de sinais (movimentos do tronco, da cabeça, do ombro, e as expressões faciais, como movimento da boca) que são produzidos em relação ao que é chamado, na literatura, de linha do tempo, uma linha imaginária, projetada no espaço de sinalização. 
A ideia do espaço em frente e ao redor do corpo do sinalizador ser conceitualizado como uma linha de tempo está presente em outros trabalhos sobre línguas de sinais. Cada localização no espaço, como se pode observar na figura 11, reproduzida abaixo, que Alkoby coloca em seu artigo, está relacionada a um determinado tempo, e as ações sinalizadas nesses locais vão ser entendidas como ações no presente, no passado (próximo e distante) ou no futuro (próximo e distante), dependendo da posição em que as mãos estarão no momento da sinalização ou dos apontamentos que forem feitos para essas localidades.

Na figura 11, a seguir, é possível ver, então, que as localizações em frente ao corpo do sinalizador indicam futuro; as de trás, ou acima do ombro, passado, e, em frente e bem próxima ao corpo ou no próprio corpo, presente.

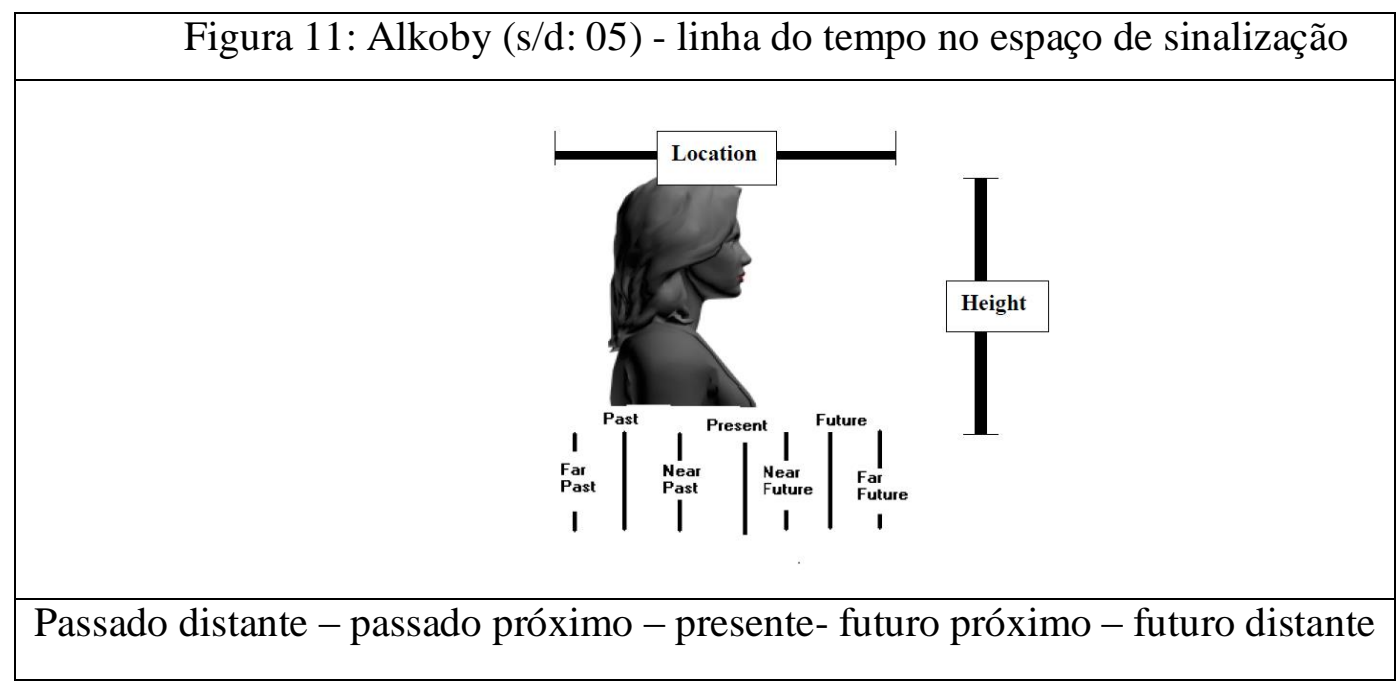

Seguindo ideias da linguística cognitiva, Johnston \& Schembri (2007) também dedicam uma seção de seu livro para tratar do tempo na língua de sinais australiana. Os autores reforçam a ideia da metáfora "tempo é espaço" e mostram que os sinais de tempo que marcam futuro são produzidos para frente, enquanto os que marcam passado são realizados para trás. Os autores também expandem a ideia sobre a linha do tempo, projetada no espaço de sinalização, e defendem que os sinais relacionados a tempo podem ser produzidos em três tipos de linha temporal: (i) a dêitica (a linha perpendicular ao corpo), relacionada ao tempo do discurso, da enunciação; (ii) a anafórica (a linha na diagonal que cruza o corpo), que depende do que já foi construído no discurso, (iii) a sequencial (a linha paralela ao corpo, que vai da esquerda para a direita), usada principalmente quando os sinalizadores querem comparar eventos e dar ordem a eles. 
Sinte (2013), ao descrever dados da língua de sinais belgo-francesa (French Belgian Sign Language - LSFB), também levanta expressões de tempo nessa língua sinalizada. Partindo do estudo de Friedman (1975) na ASL, argumenta que as línguas de sinais, por não apresentarem um sistema flexional para expressar o tempo, transmitem suas informações temporais por meio de itens lexicais ou por outros elementos gramaticais situados no espaço, na linha do tempo.

A autora destaca como marcadores de tempo os itens lexicais adverbiais, que são sinais que ela considera "marcadores específicos" de tempo, apontamentos para o espaço de sinalização, algumas expressões faciais, relacionadas ao olhar, e os movimentos do tronco. Com base nos estudos sobre ASL, Sinte também relaciona localizações no espaço em frente e ao redor do sinalizador com os tempos presente (em frente e próximo ao corpo de quem sinaliza), futuro (em frente e mais distante do corpo) e passado (espaço atrás do corpo). As localizações espaciais também são importantes para a marcação do tempo do calendário, como os dias da semana, da esquerda para a direita, ou momentos do dia, à direita do sinalizador, de cima para baixo.

Nesse estudo, baseado também em Liddell (2003), Sinte apresenta a análise de diferentes textos, entre eles, entrevistas de estudo e de emprego, e observa, em especial, que a direção do olhar tem um papel fundamental na marcação temporal de um texto, pois serve como uma âncora, um ponto de referência (p.223). Nos dados da autora, aparece um exemplo de marcação ambígua de tempo entre o tempo presente e uma não marcação temporal, pois não há uma marca explícita de tempo em um de seus textos. Para ela, não se pode dizer que uma não marcação signifique a instauração de um tempo presente default e considera um caso de uma marcação de tempo não definida. Nos dados sobre libras desta pesquisa, aparece um caso muito parecido a esse descrito por Sinte. No capítulo 4, apresento uma forma diferente de analisá-lo no âmbito da semiótica greimasiana.

No Brasil, temos a tese de Finau (2004), que faz uma descrição do aspecto e do tempo em $\operatorname{libras}^{58}$. A autora, primeiramente, apresenta duas formas de se analisar o tempo. Uma delas é a que considera a flexão como parâmetro fraco e, nesse caso, destaca o emprego de itens lexicais, como advérbios, e a linha de tempo para marcar presente, passado ou futuro nas línguas de sinais. Segundo a autora, esses estudos, em geral, falam pouco de aspecto. A segunda forma de analisar o tempo é a partir da ideia que considera a flexão verbal como parâmetro forte. As investigações, como a dela, que seguem essa segunda proposta de análise, consideram que, além dos sinais de

\footnotetext{
${ }^{58}$ Um estudo sobre aspecto em língua de sinais americana é o trabalho de Maroney (2004), e uma descrição do tempo e do aspecto, na língua de sinais mexicana, é o trabalho de Mintz (2005).
} 
tempo, há afixos aspectuais nas línguas de sinais, que são marcados por características no movimento dos sinais. A autora identificou, por exemplo, uma relação entre a repetição de alguns sinais verbais com o aspecto imperfectivo, em libras.

Seguindo as ideias de Ferreira-Brito (1995), Quadros (1999) e Felipe de Souza (1998), Finau mostra que a marcação de tempo em libras está relacionada à flexão de aspecto verbal ${ }^{59}$. A autora, ainda, cita trabalhos como o de Amaral, Coutinho \& Martins (1994), na língua de sinais portuguesa, para defender a relação entre o tempo e o aspecto. Em seu trabalho, a autora também levanta um número grande de sinais específicos que indicam tempo, e observa, como outros autores, que a direção dos movimentos dos sinais para trás e/ou para baixo e para frente e/ou para cima é determinante para estabelecer as noções, respectivamente, de passado e futuro, mais do que considerar apenas a localização dos sinais em relação ao tronco do sinalizador. Mais um trabalho, portanto, que corrobora as ideias tanto sobre um conjunto de elementos envolvidos na marcação temporal quanto sobre a linha do tempo no espaço de sinalização.

\section{3) Outro olhar sobre o tempo nas línguas de sinais}

Embora os trabalhos sobre o tempo em diferentes línguas de sinais tenham chegado a conclusões muito próximas e relacionem a marcação temporal à sua projeção do espaço, é interessante notar que eles não salientam a possibilidade de esta construção espacial do tempo ser altamente variável e de, portanto, depender de cada texto, de cada situação discursiva. Quando nos propomos a olhar para as línguas de sinais, considerando que, por possuírem um canal de produção visual que permite uma gestualidade rica, não podemos deixar de lado toda capacidade de movimento, de realização dos sinais, de alterações corporais que podem estar envolvidas na construção dos enunciados e na instauração das categorias enunciativas.

Apresento, a seguir, alguns exemplos, que serão mais bem analisados no capítulo 4, para discutir alguns pontos sobre a marcação temporal levantados na literatura, o que levou a formulação das hipóteses de trabalho desta pesquisa.

Como foi mostrado, os pesquisadores, em geral, costumam dizer que o tempo pode ser projetado espacialmente como uma linha perpendicular ao corpo. É possível perceber, no entanto, em dados de libras analisados, que essa linha temporal pode ser construída espacialmente de outras maneiras, durante uma sinalização, como sugere Johnston \& Schembri (2007).

\footnotetext{
${ }^{59}$ Diferentemente de Finau (2004), Maroney (2004) entende o aspecto como sendo uma derivação verbal, não uma flexão.
} 
Na figura 12, temos um exemplo interessante de um texto em libras, intitulado "aula de história" e sinalizado pela pesquisadora e intérprete de libras Profa. Da. Neiva Albres (Universidade Federal de Santa Catarina - UFSC) ${ }^{60}$. Nele, a linha temporal é projetada, em frente ao corpo da sinalizadora, na horizontal.

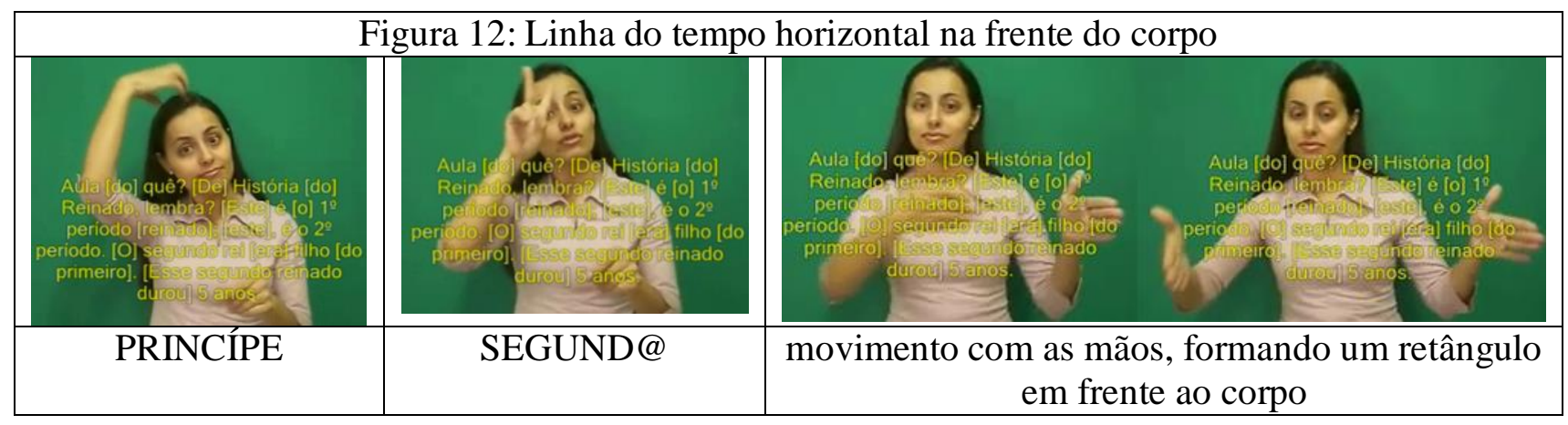

É possível observar que Neiva constrói as relações temporais, com um gesto manual metafórico (as mãos delimitam os espaços que correspondem aos períodos de tempo dos quais está falando), em uma linha imaginária, que vai da esquerda para a direita. Neiva está explicando o período imperial no Brasil, e, para diferenciar os períodos do primeiro e do segundo reinados, divide essa linha que criou, e, com o auxílio de um apontamento, mostra qual é o espaço que corresponde ao segundo imperador, fazendo o sinal de SEGUNDO, mais a sua direita, e de PRIMEIRO mais a sua esquerda, como mostra a figura em 13, abaixo.

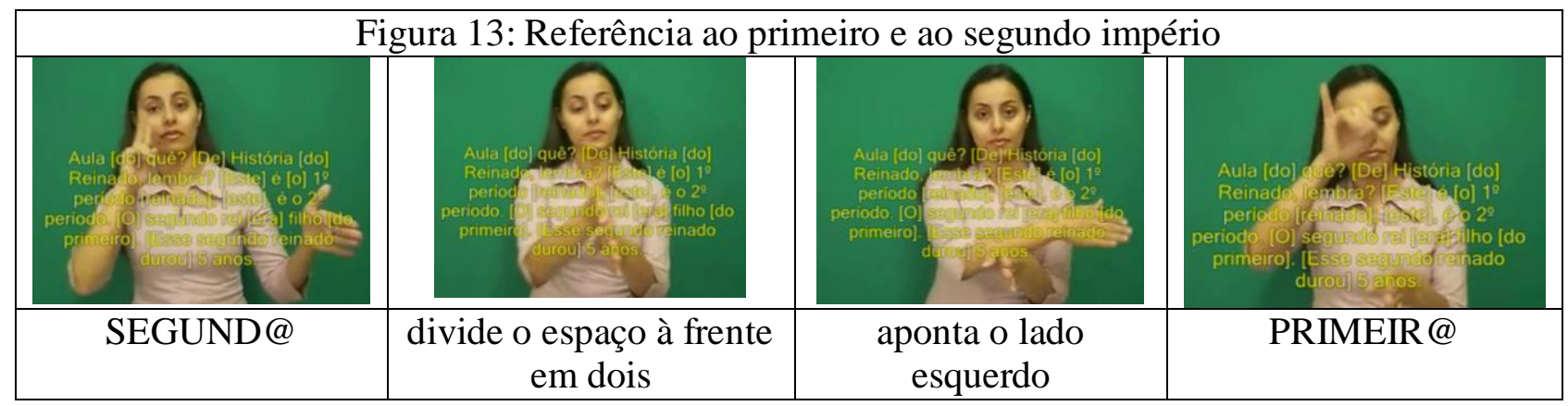

Após essa divisão espacial, Neiva continua se referindo aos dois períodos, no texto, e, para dizer que o segundo imperador era filho do primeiro, ela mostra, com um gesto manual, o período delimitado mais à direita, faz o sinal DOIS, que corresponde a D. Pedro II, depois

\footnotetext{
${ }^{60}$ Todas as figuras que foram referentes aos textos analisados nesta tese possuem um videoclipe no DVD que acompanha este trabalho. É possível, portanto, assistir ao trecho do vídeo selecionado como exemplo.
} 
FILH@ e aponta para o outro espaço, à esquerda, que corresponde ao primeiro imperador, como pode ser visto na figura 14.

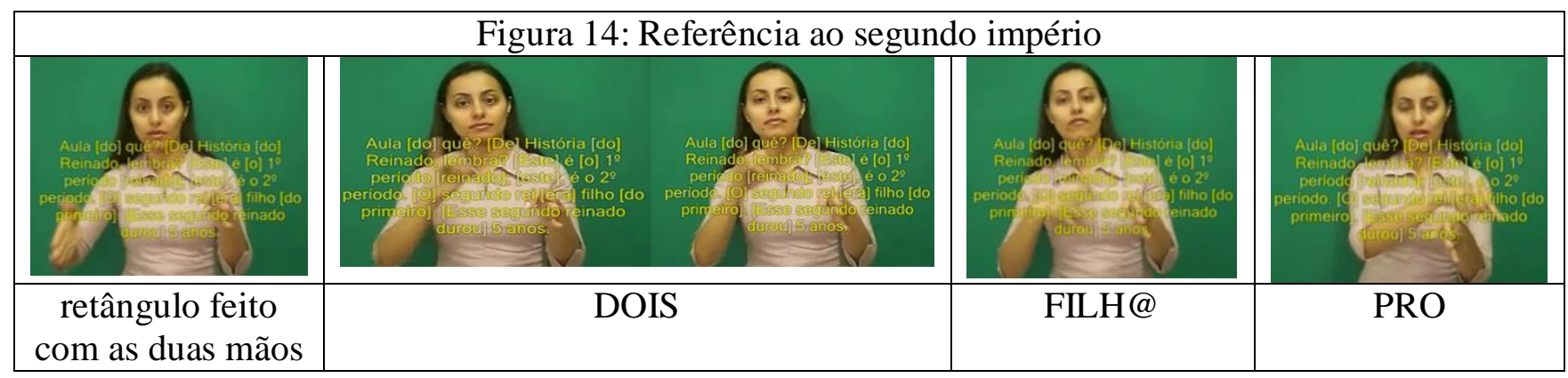

É possível notar que, além dos gestos manuais, o corpo também ajuda na referência dos dois períodos, uma vez que, o tronco de Neiva inclina-se para a direita, enquanto sinaliza FILH@, e, para a esquerda, quando aponta o espaço do primeiro reinado, na figura acima. Percebe-se, nessa sinalização, não só uma marcação espacial e temporal, mas também a de pessoa.

Em seguida, na figura 15, Neiva novamente delimita o espaço referente ao segundo império e diz que ele durou cinco anos. Fica clara, em sua sinalização, que o tempo foi construído espacialmente, mas em frente ao corpo dela. Seguindo a proposta descritiva de Johnston \& Schembri (2007), é possível analisar esse tipo de projeção da linha do tempo como sendo a sequencial (a linha paralela ao corpo, que vai da esquerda para a direita), pois foi usada para que a sinalizadora pudesse falar de dois eventos e dar uma ordem a eles.

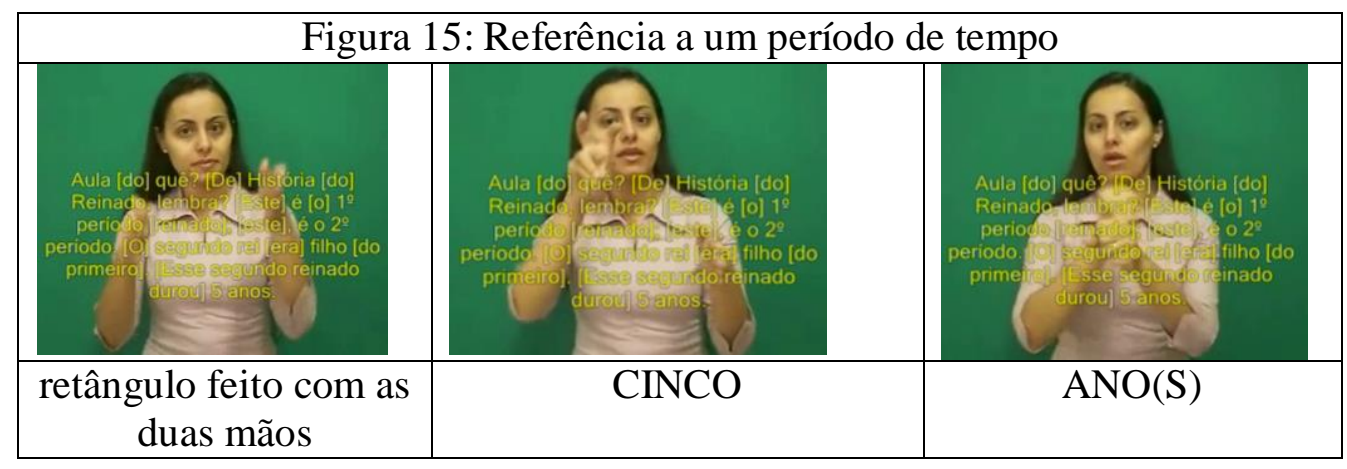

Como foi visto na seção anterior, a maior parte dos autores não argumentam a favor da existência de morfemas de flexão de tempo nos verbos das línguas de sinais. Mas muitos estudos tratam o movimento do corpo do sinalizador para frente e para trás como um tipo de marcador específico de tempo. 
Também verificamos, em libras, o movimento do corpo associado a tempo em algumas sinalizações. Há exemplos em libras que também mostram que o tronco do sinalizador vai para trás, ao realizar um sinal PASSADO, por exemplo, como nas figuras 16 e 17, que apresentam, respectivamente, trechos dos textos do corpus desta pesquisa, "Metáfora - O escorpião e a tartaruga", sinalizado pelo surdo Rimar Segala, e "Dúvida”, também sinalizado por Neiva.
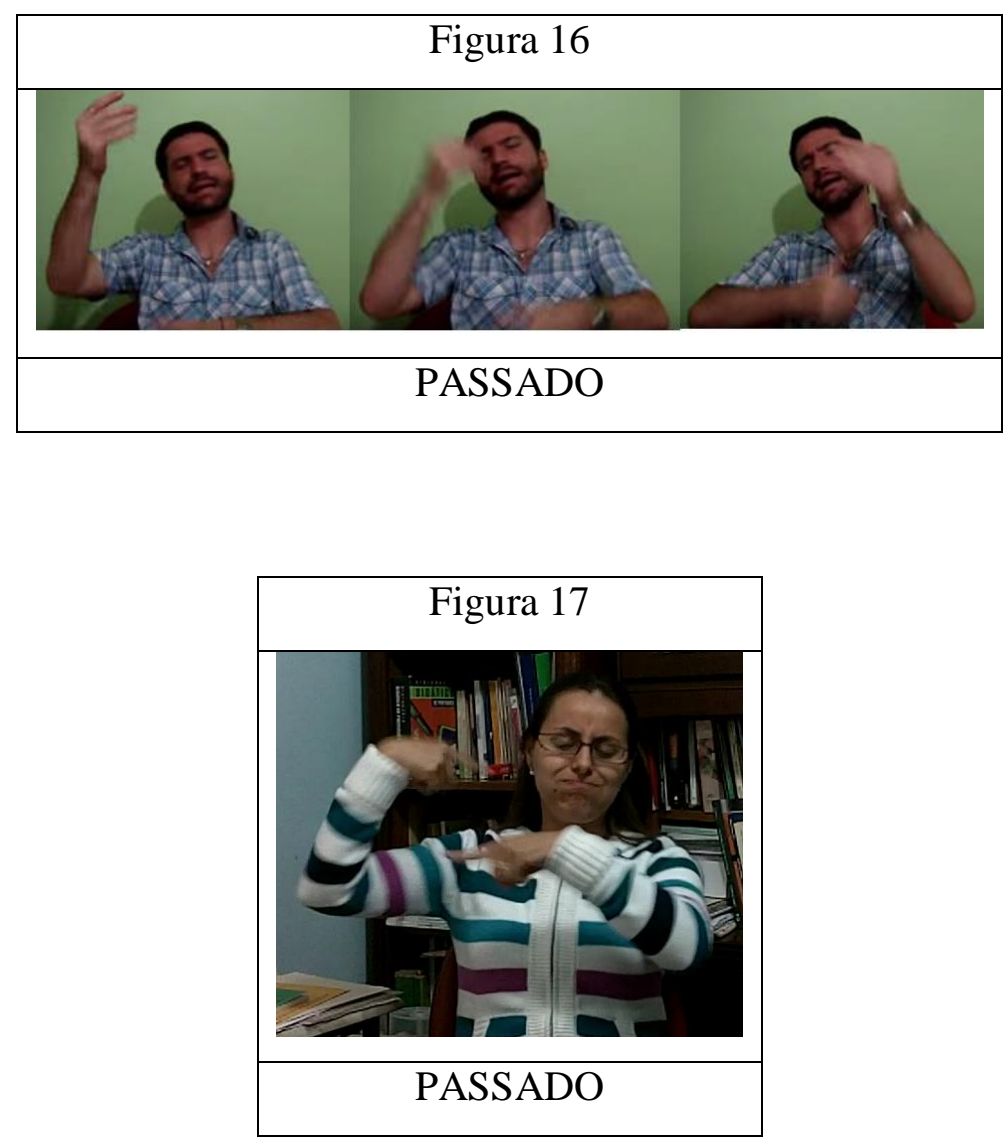

Nos casos em que há a realização do sinal FUTURO, também há casos em que se pode notar o movimento do tronco para frente ou os sinais serem realizados mais afastados do corpo de quem sinaliza, quando há a narração de algo que ainda vai acontecer. Na figura 18, abaixo, temos um trecho de uma outra história sinalizada por Neiva. Nele, há a realização do sinal que indica tempo futuro e uma inclinação do corpo da sinalizadora para frente. As mãos da sinalizadora também se afastam do corpo. 


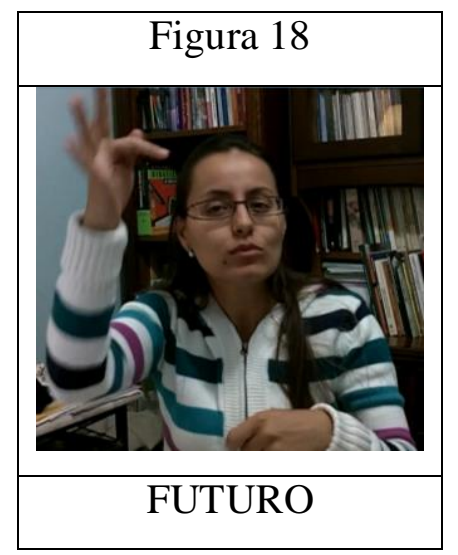

Em outro exemplo, sinalizado também por Neiva, é possível notar uma inclinação da cabeça da sinalizadora, no momento em que realiza o sinal AMANHÃ, na figura 19.

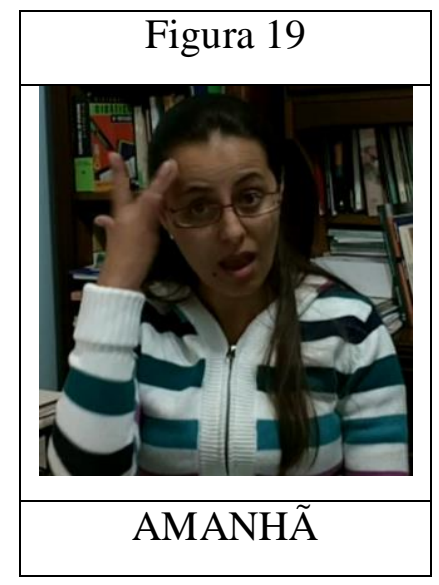

Na figura 20, que mostra um trecho do texto "Sonho com um carro novo", sinalizado pela surda Regiane Agrella, também é possível notar uma característica da realização do tempo futuro, sugerida pela Literatura.

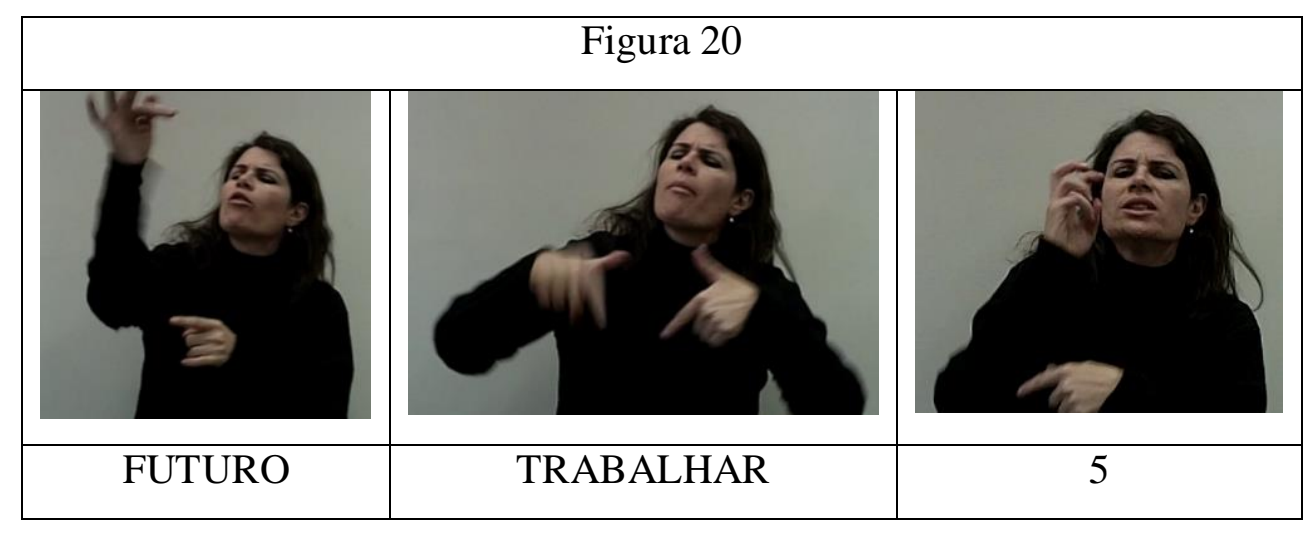


O tronco de Regiane não se inclina para frente, mas os sinais que ela realiza durante esses enunciados na figura 20 são, devido a sua articulação, dirigidos para frente, mas de forma mais afastada do corpo, voltados para cima. Como este momento do texto corresponde a uma fala de uma das personagens da história, o corpo da sinalizadora já estava posicionado mais para a esquerda, inclinado para trás. Além disso, é possível ver a cabeça também inclinada para trás e os olhos, em alguns momentos quase fechados. Como a fala da personagem é uma pergunta, pode-se dizer que essa postura é para realizar uma interrogativa na língua, não necessariamente para marcar o tempo.

É possível perceber, nos exemplos levantados em libras, portanto, que, nem sempre o deslocamento do corpo do sinalizador, no espaço, para frente ou para trás, ou para a direita ou para a esquerda, ocorre. Até mesmo em situações em que os sinais de PASSADO ou ATRÁS (2) (que também indica passado nos textos), por exemplo, aparecem, o tronco do sinalizador pode não sofrer grandes alterações e se manter neutro ou pouco inclinado, durante a sinalização, como é possível notar, nas figuras 21 e 22 , abaixo ${ }^{61}$.
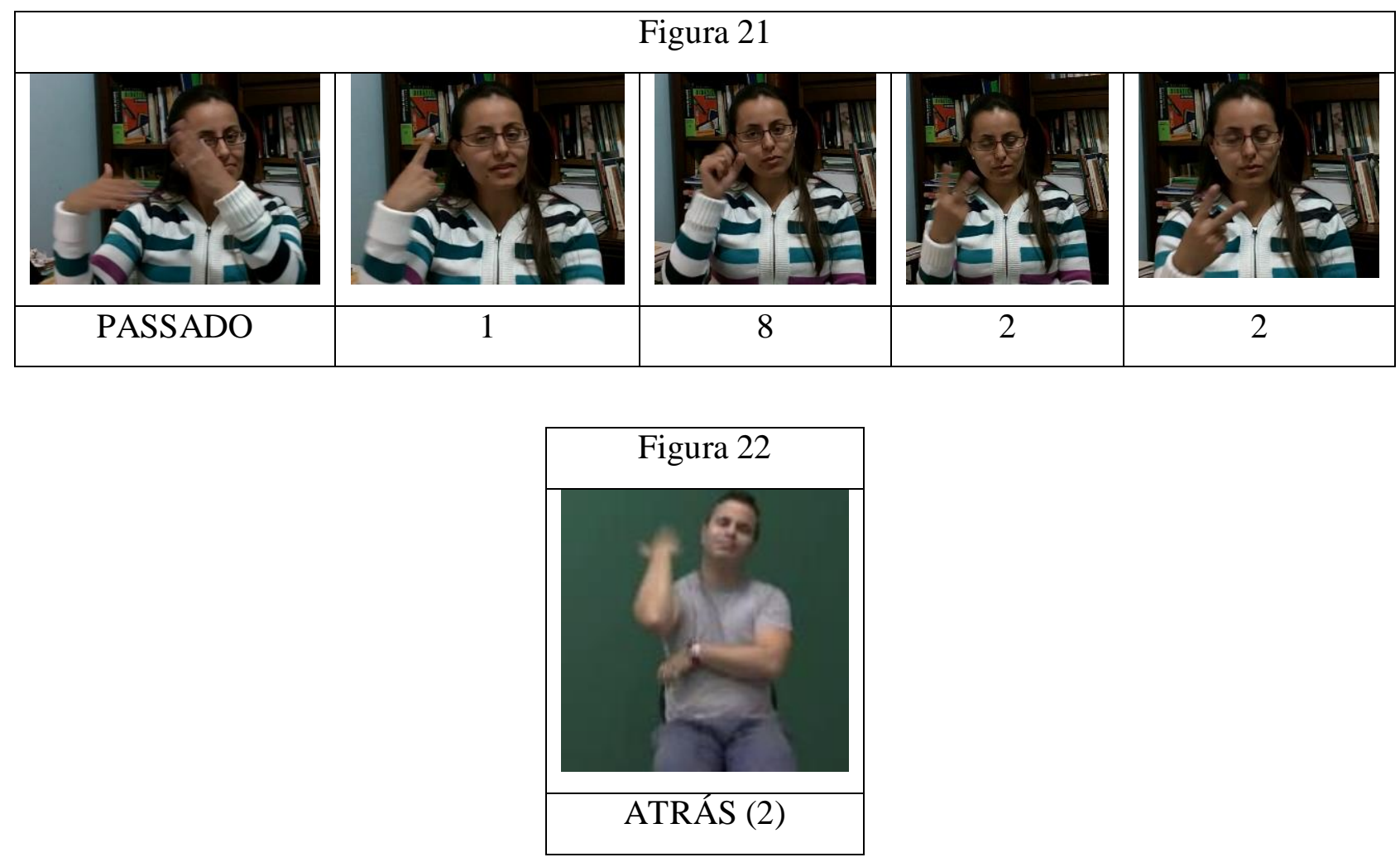

${ }^{61}$ A figura 21 corresponde a um enunciado de libras, sinalizado por Neiva Albres, que foi eliciado a partir da sentença em português "Em 1822, D. Pedro II proclamou a Independência do Brasil". A figura 22 registra um momento do texto "O amor é surdo", sinalizado pelo surdo Celso Badin. 
Também é preciso considerar que, nem todo deslocamento do tronco do sinalizador é realizado com o intuito de construir relações temporais. Outras razões discursivas, como a referência de pessoa, a criação de discursos diretos no interior dos textos, a representação das personagens e das ações delas também podem motivar alterações corporais e movimentação no espaço de sinalização diversa. Na figura 23, pode-se ver um desses momentos em que o tronco do sinalizador se moveu para marcar pessoa e simular um diálogo, no texto "Metáfora - O escorpião e a tartaruga", sinalizado por Rimar.

\begin{tabular}{|c|c|}
\hline \multicolumn{2}{|c|}{ Figura 23: diálogo entre o pai e a filha } \\
\hline O pai & A filha \\
\hline & \\
\hline O pai de Rimar dizendo que não \\
entendeu
\end{tabular}

Na figura 23, acima, podemos observar que o deslocamento do corpo para a direita, primeiramente, cria o espaço para o pai, que pergunta a sua filha o significado da palavra “instinto". Em seguida, o corpo se move para outra direção, e o narrador dá voz à filha. Nota-se que, com as mudanças do tronco, também há alteração no movimento da cabeça, nas expressões faciais, e, em especial, nos olhos. Isso também é possível de observar em trechos do texto "História do Gibi 1", como o que aparece na figura 24.

\begin{tabular}{|c|c|}
\hline \multicolumn{2}{|c|}{ Figura 24: diálogo entre o Cebolinha e a Magali } \\
\hline Cebolinha & Magali \\
\hline & \\
\hline AJUDAR & EU $^{62}$ (mão direita) e ÁRVORE (mão esquerda) \\
\hline
\end{tabular}

\footnotetext{
${ }^{62}$ Pode-se fazer a notação PRO-1 para o sinal para EU, seguindo o modelo de descrição de Liddell (2003).
} 
O corpo do sinalizador também pode sofrer alterações em seu movimento, dependendo do que o discurso quer apresentar. Se a ação da personagem exigir que o tronco se incline para trás ou para frente, esses deslocamentos corporais não serão decorrentes da marcação temporal. Em um trecho do texto, "Imaginação", sinalizado por Neiva, ocorre uma representação da gestualidade de uma das personagens, o marido, como podemos ver na figura 25.

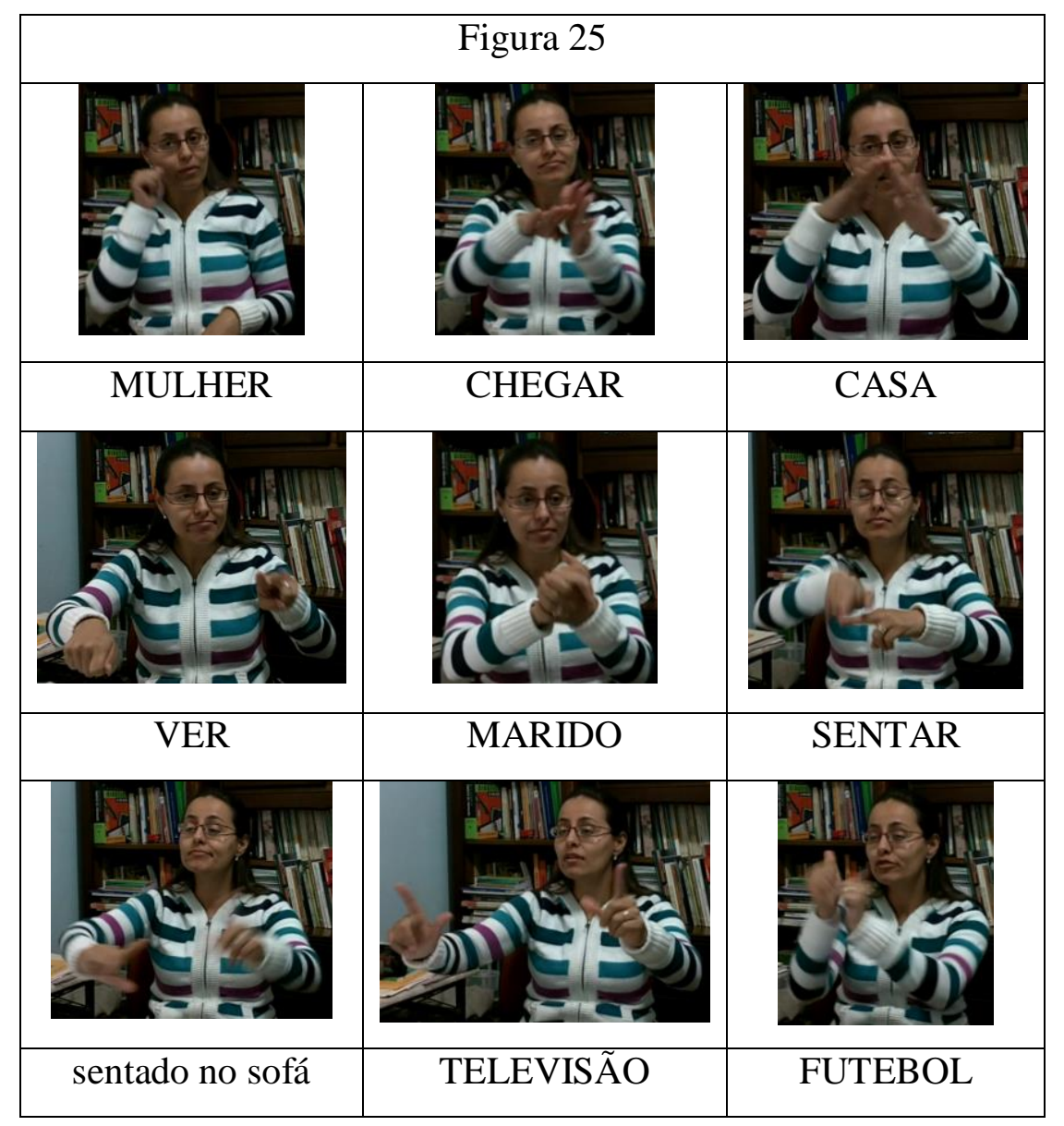

É visível a alteração do corpo da sinalizadora, que se inclina para trás, sem necessariamente marcar passado, nesse instante da história, para mostrar como o marido estava quando sua mulher entrou em casa. Também é possível observar uma diferença no corpo de Neiva, ao sinalizar MULHER e contar que ela chegou e viu seu marido vendo futebol. Nesse momento, a postura do tronco é neutra. Quando ela representa o marido, a postura muda, fica mais relaxada, os sinais ficam mais distanciados do corpo, e, como é uma forma de imitar uma pessoa sentada no sofá, seu corpo precisou fazer um movimento diferente. A direção do olhar e as expressões faciais de Neiva também se alteram, durante a representação de cada uma das personagens. Muitas vezes, a localização das mãos no espaço pode indicar algum tempo 
diferente, mas, na sinalização vista, não é essa intenção, mas as propriedades articulatórias do sinal. TELEVISÃO é um sinal que pode ser realizado mais distanciado do tronco, por exemplo.

No texto "Dúvida", também de Neiva, é possível ver, também, uma situação em que o corpo inclinado para frente não indica tempo futuro, mas sim, demonstra um determinado tipo de ação. Ao sinalizar CARRO, a sinalizadora move seu corpo para frente, representando o próprio ato de dirigir. Há também alterações no modo de olhar durante a sinalização, como é possível ver na figura 26.

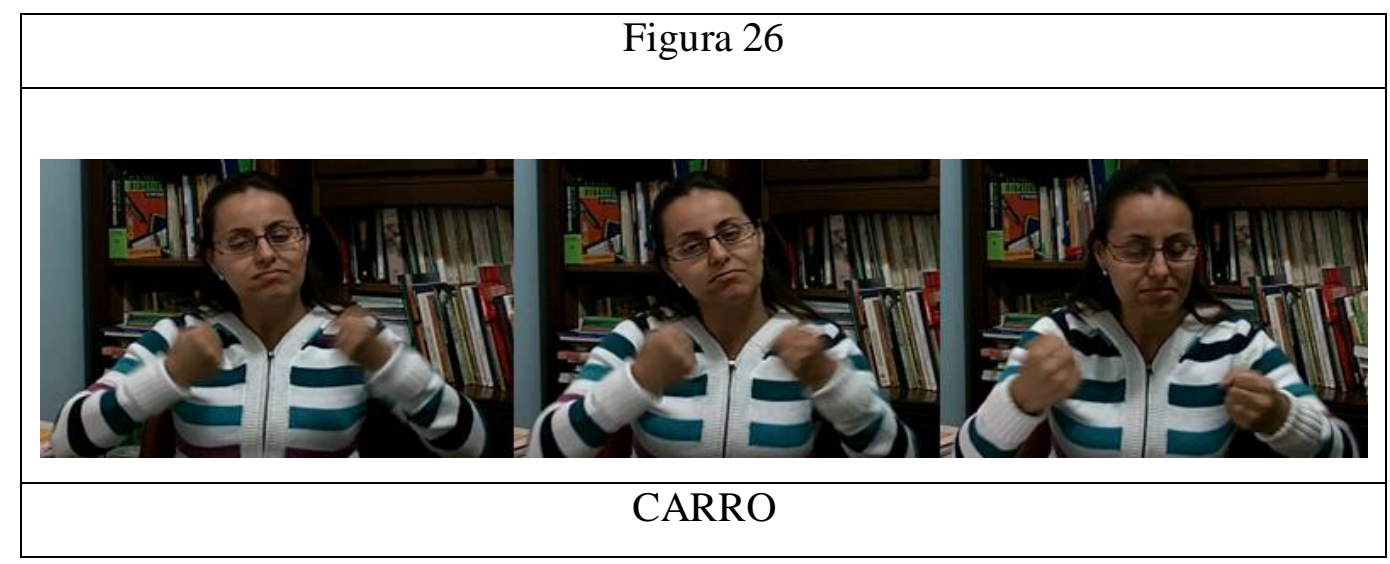

Mais um caso, encontrado no texto "Metáfora - O escorpião e a tartaruga", ilustra o fato de, muitas vezes, em um discurso, haver movimentos do corpo do sinalizador que não são específicos de tempo. Na figura 27, é possível ver um momento da história em que há a demonstração de uma tartaruga caminhando. O corpo se inclina para frente, a cada passo do animal, e também se notam os olhos fechados e uma expressão fácil que caracteriza a tartaruga.

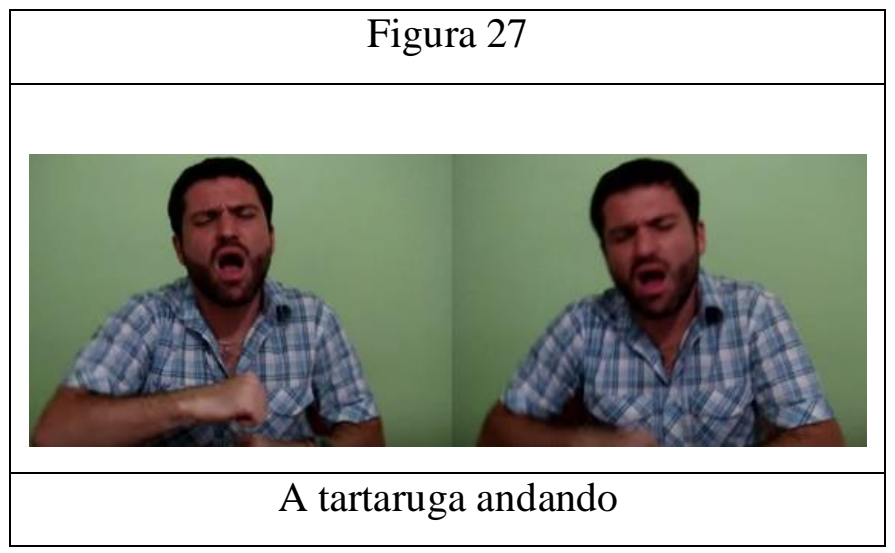


No mesmo texto de Rimar, é possível ver o momento em que o escorpião se depara com um rio e olha para baixo, para olhar para a água. Na figura 28, nota-se, então, o corpo do sinalizadora inclinado para frente, para poder representar a cena de a tartaruga andando (demonstração da ação da personagem). Novamente, esse movimento não indicou futuro, por exemplo.

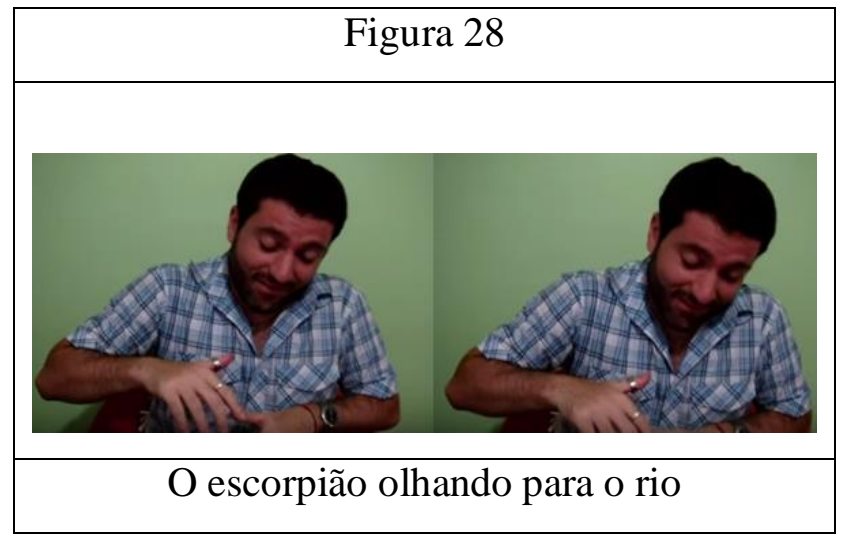

Como essa localização do corpo no espaço parece variar conforme a situação discursiva (o corpo pode ir para trás de diferentes modos, não sempre do mesmo), teríamos também de levantar, como fez Liddell $(1995,2003)$ no caso dos verbos indicadores, ou a hipótese de que essas línguas têm uma quantidade enorme de morfemas que podem indicar, por exemplo, passado, se for considerar cada um dos movimentos para trás como um elemento gramatical diferente que marca esse tempo, ou a hipótese de que há uma alomorfia ilimitada, sem condicionamentos muito definidos, e que o morfema de tempo para passado, por exemplo, pode variar infinitamente. Como observa Viotti (c.p.), a alomorfia nas línguas naturais costuma ser condicionada por fatores fonético-fonológico e morfossintático. Se as variações dos gestos corporais que não foram condicionadas por essas razões, mas sim, por alterações no contexto de sinalização, mesmo que sejam alterações pequenas, não se pode falar em morfema, menos ainda, em um morfema específico de tempo, já que muitos desses gestos podem indicar outras informações também no texto.

A hipótese que este trabalho levanta é a de que, como já tem sugerido a Literatura, há de fato um conjunto de estratégias gramaticais e discursivas, próprio de sua modalidade visual, para marcar e organizar o tempo nos textos. Fazem parte dele tanto os itens lexicais, dicionarizados ou não, que já têm a função adverbial de tempo cristalizada, como os sinais PASSADO e FUTURO, 
como também os marcadores corporais, como movimento do tronco, da cabeça, localização das mãos no espaço e a direção do olhar do sinalizado. Esses marcadores, no entanto, não seriam específicos de tempo, mas de todas as categorias enunciativas, e podem ou não ocorrer sempre com o mesmo intuito no discurso. Eles variam bastante, podem acontecer juntos ou separados, podem se alterar ou ter outra função no texto. Todos esses gestos parecem marcar, entre outras coisas, pessoa e espaço também na língua, o que mostra uma relação estreita entre essas categorias discursivas e, em especial, do tempo com o espaço. Os exemplos apresentados nesta seção mostram que a localização das mãos no espaço, e, principalmente, a direção do olhar do sinalizador parecem mais regulares e sistemáticos na marcação temporal, como será mais bem analisado no capítulo 4.

Meu trabalho se diferencia do de Finau (2004), que também descreveu o tempo em libras, em especial, pela maneira como entendemos a marcação temporal dessa língua. Nossas análises partem de pressupostos teóricos diferentes, o que também distancia a nossa abordagem com os dados e com a própria noção de tempo. Primeiramente, a teoria usada para realizar esta pesquisa não considera que o aspecto, em libras, é um tipo de flexão do verbo, como argumenta Finau ${ }^{63}$. Mesmo porque a ideia deste trabalho foi apenas olhar para a marcação temporal na língua. A investigação do aspecto e sua associação com a referência de tempo ainda não foi realizada por este estudo. Além disso, por razões que já foram colocadas neste capítulo, meu trabalho não partirá da ideia de que tempo e aspecto são distintos e tratados de forma teórica diferente dentro da emiótica greimasiana. Desse modo, a descrição que proponho não será a mesma que a dela.

Algumas características sobre a marcação temporal em libras que Finau aponta, entretanto, precisam ser consideradas neste estudo. As observações a respeito da direção do olhar, do movimento do corpo e da localização dos sinais no espaço de sinalização, na chamada linha do tempo, são de grande valia para a análise que apresento nesta tese. Este estudo não tem, no entanto, a preocupação de dizer que um ou outro desses recursos da língua equivale a qualquer tipo de morfema, como os entendemos até hoje nas línguas orais.

\footnotetext{
${ }^{63}$ Segundo Greimas \& Courtés (2012: 39), entende-se aspecto, historicamente, como um ponto de vista sobre a ação e algo que pode se manifestar "sob a forma de morfemas gramaticais autônomos". Dentro da teoria semiótica, a aspectualização, no nível discursivo do percurso gerativo de sentido, é entendida como um conjunto de categorias aspectuais por meio do qual um actante observador pode se revelar. Segundo os autores, esse procedimento envolve a actorização, a espacialização e a temporalização.
} 


\section{4) Considerações finais do capítulo}

Neste capítulo, inicialmente, apresentei alguns estudos sobre o tempo presentes na literatura sobre as línguas de sinais, dos quais destaquei Alkoby (s/d), Sinte, 2013, Johnston \& Schembri, 2007 e Finau, 2004. A ideia foi mostrar os resultados a que esses autores chegaram em suas pesquisas, para depois, discutir as conclusões obtidas e propor uma nova forma de olhar para os fenômenos descritos. Os dados apresentados por esses trabalhos resenhados são, de certa forma, bastante próximos ao que foi possível observar nos textos em libras e que será apresentado no capítulo 4, e até confirmam as hipóteses inicias da tese de que não há morfemas flexionais de tempo nos verbos das línguas de sinais de tempo e que há várias formas de marcar o tempo, espacialmente, criando pontos sobre uma linha de tempo imaginária que toma o corpo do sinalizador como referência. Mas, por outro lado, discuti, também, essas ideias, mostrando que essa linha temporal pode não ser fixa e variar conforme a situação de enunciação, e que o conjunto de estratégias envolvido na marcação do tempo é composto de estratégias discursivas variadas, que também podem indicar pessoa e espaço, motivadas, algumas vezes, pelos próprios sinais que são realizados no enunciado. 


\section{Capítulo 3}

\section{A metodologia da descrição do tempo em libras}

"Enquanto o tempo acelera e pede pressa Eu me recuso faço hora vou na valsa"

Paciência

Lenine

Neste capítulo, o objetivo é apresentar a metodologia, que foi adotada para a coleta, registro e transcrição dos dados desde o projeto, e como a descrição proposta nesta tese foi desenvolvida. Primeiramente, discorremos sobre o levantamento dos dados, tanto dos itens lexicais de tempo dicionarizados como outros elementos gramaticais e discursivos envolvidos com a organização temporal em uso, nos discursos sinalizados. Em seguida, descrevemos cada um dos seis textos que formam o corpus desta pesquisa e comentamos como eles foram criados e transcritos. Apresentamos, ainda, o modelo de transcrição que tem sido adequado para a descrição dos dados em libras, uma vez que permite registrar todos os detalhes do plano de expressão das sinalizações, Para finalizar, propomos uma segmentação de dois dos textos do trabalho, para ilustrar os primeiros passos da análise do conteúdo que será apresentada no capítulo 4 desta tese.

\section{1) O levantamento de dados}

Para iniciar a descrição das marcas e estratégias para instaurar o tempo nos discursos em libras, foi necessário levantar os dados que seriam estudados e construir o corpus de trabalho desta pesquisa. Esse levantamento de dados consistiu em: (i) uma seleção de itens lexicais dicionarizados, que são basicamente gestos manuais, já convencionalizados como marcadores de tempo na língua, como o sinal ONTEM ou AMANHÃ; (ii) uma identificação de outros possíveis gestos da língua, presentes ou não no dicionário e que podem, em uso, comportar-se como indicadores temporais, ou que podem estar, de alguma maneira, relacionados à marcação de tempo nos textos, tanto os que foram eliciados a partir do português quanto os que foram produzidos semi-espontaneamente em libras e selecionados para esta pesquisa. 


\subsection{1) Levantamento dos itens lexicais dicionarizados}

Como já foi dito, a libras possui um léxico próprio para marcar o tempo em seus discursos. Em razão disso, primeiramente, o trabalho investigativo consistiu em levantar sinais usados para fazer essa referência temporal que estivessem registrados em dicionário e fossem, portanto, convencionais e mais compartilhados entre os usuários da língua. Iniciamos essa compilação de sinais a partir do dicionário de Capovilla \& Raphael $(2001)^{64}$. Selecionei os verbetes que são descritos pelos autores como sendo de signos usados especificamente para marcar tempo, com função adverbial, como os sinais de AGORA, PASSADO e FUTURO. Guieime, nesses casos, pela classe gramatical atribuída ao sinal (advérbio de tempo), pela tradução dele tanto para o português quanto para o inglês, e também pelo seu significado. Na tabela abaixo, apresento alguns exemplos desses sinais que foram levantados e que são considerados marcadores temporais pelo dicionário de Capovilla \& Raphael, e também por materiais didáticos da língua, de onde as ilustrações foram retiradas, sem qualquer dúvida ${ }^{65}$.

\footnotetext{
${ }^{64} \mathrm{O}$ dicionário que foi utilizado nesta pesquisa é o de Capovilla \& Raphael (2001), que é um dicionário enciclopédico e trilíngue. Ele é o único dicionário de libras, mas é o trabalho lexicográfico mais completo e detalhado (com figuras, descrição dos sinais, significado e tradução para o português e para o inglês) feito até o momento no Brasil. A versão mais recente e atualizada desse trabalho é a de Capovilla, Raphael \& Maurício, 2012.

${ }^{65}$ As figuras que aparecem nesta seção do texto foram retiradas de duas apostilas diferentes de libras disponíveis na internet. A ideia é trocar esses desenhos de sinais por fotografias desses mesmos itens sendo realizados por uma usuária da língua. Agradeço, desde já, as imagens, a colaboração e todo apoio de Andrea Iguma para esta pesquisa.
} 


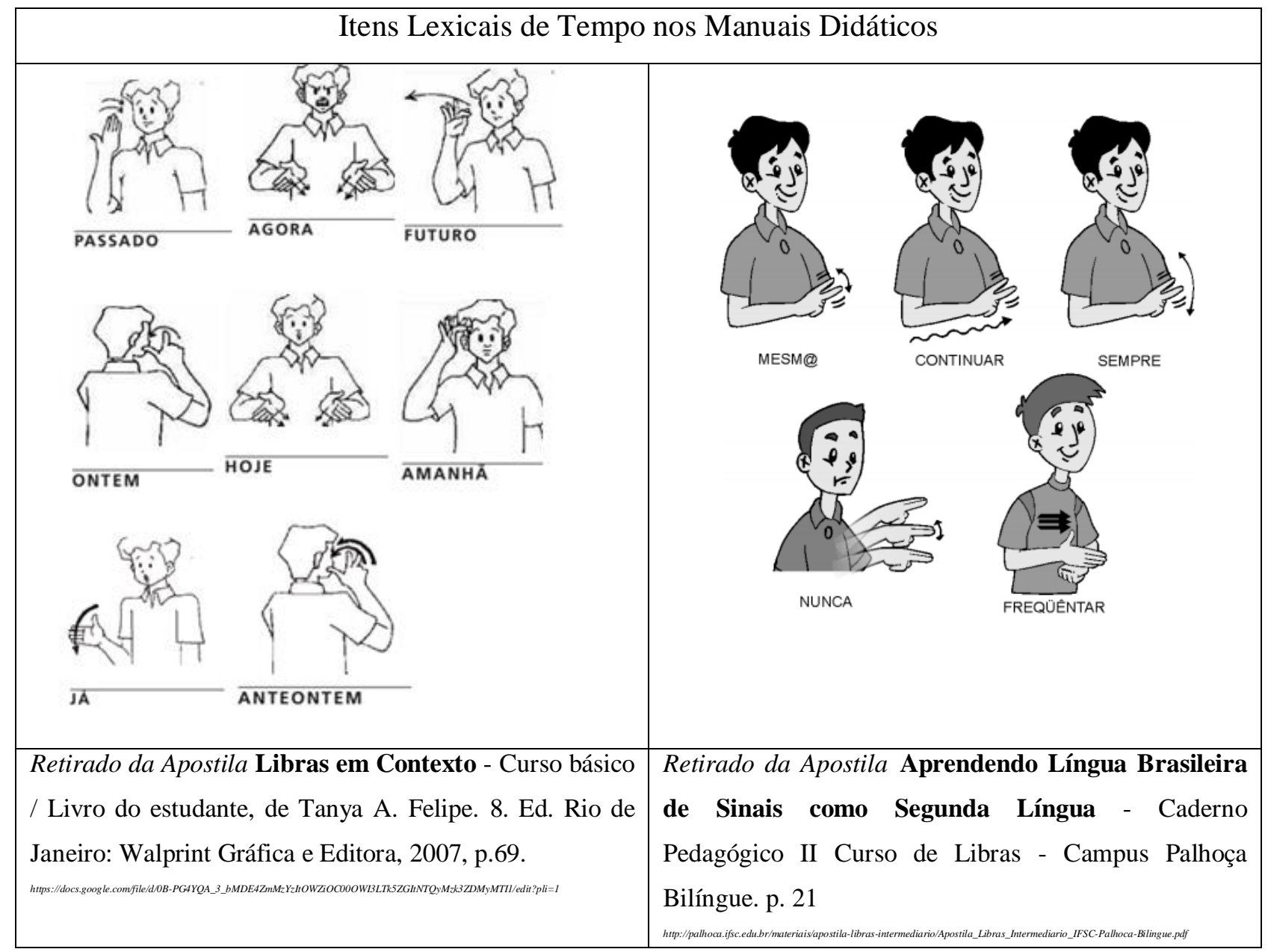

Também selecionamos para o trabalho os sinais que já foram observados em situação de uso entre os surdos, para marcar alguma relação temporal em seus textos, embora o nome do sinal, em português, não esteja relacionado necessariamente a esse tipo de marcação discursiva, como é o caso do sinal IMAGINAR, usado para introduzir hipóteses, eventos que podem acontecer, no futuro ou tempos do modo subjuntivo (tempos irrealis). No anexo 2 desta tese, apresentamos uma tabela com os verbetes selecionados, em ordem alfabética, com o nome dado por Capovilla \& Raphael, em português, com letra maiúscula, e com a indicação da página em que aparecem no dicionário ${ }^{66}$.

${ }^{66}$ Alguns nomes de sinais dessa tabela, em anexo, são acompanhados de um número, como AGORA (1) e AGORA (2). Esses números foram colocados pelos autores do dicionário para identificar diferentes pronúncias de um mesmo sinal ou sinais distintos, mas com significados muito próximos, ou até que significam a mesma coisa e que se referem, no caso, a um mesmo tempo: AGORA (1), por exemplo, é realizado com uma mão, e AGORA (2), com as duas. Isso pode ser visto como um tipo de variação linguística no nível do léxico da língua. Também há casos em que essas diferenças na sinalização são marcadas por verbetes diferentes, para representar dois sinais diferentes, com usos específicos, e, nesse caso, não se trataria de uma variação, embora, na tradução para o português, os sinais tenham recebido o mesmo nome, no dicionário, como é o caso de CRESCER (1) e (2). 
Nessa primeira investigação dos itens lexicais, foram levantados 155 sinais. Esse número não parece refletir de fato a quantidade de signos que podem marcar tempo em libras. Se considerarmos que foram selecionados todos os verbetes que tinham o mesmo tipo de sinalização, mas que foram traduzidos para o português com nomes diferentes, como é o caso de BASTA! (2) e CHEGA! (1), teremos uma lista menor ${ }^{67}$. Mas pode-se dizer, também, que é possível que haja mais sinais que indicam tempo na língua do que aparece na lista, pois muitos dos itens selecionados podem, em uso, carregar uma informação temporal, mas, a partir de seu nome, em português, não fazem qualquer menção direta a tempo, como CRESCER (1) e (2), ACOSTUMAR e TRANSFERIR (2), ou, ainda que faça, como os nomes para período de tempo, como ABRIL, DOMINGO, FIM, MANHÃ, INVERNO, etc., que, talvez, tivessem que ser entendidos como expressões adverbiais. Nesse sentido, pode-se pensar que, do mesmo modo que alguns sinais foram incluídos a mais na lista, por serem na verdade sinais repetidos, com nomes diferentes em português, outros eventuais marcadores de tempo podem ter ficado fora dela, até por se tratar de uma investigação feita na primeira versão do dicionário ${ }^{68}$.

Esse trabalho se revelou insuficiente para os propósitos desta tese, uma vez que os marcadores de tempo em libras não se restringem aos itens lexicais apenas. Diante disso, foi necessário, então, fazer uma nova seleção de léxico temporal, usando outro tipo de método de coleta de dados. A ideia foi observar que marcadores são usados em pequenos enunciados de libras, produzidos por duas colaboradoras da pesquisa, uma ouvinte fluente na língua e uma surda, que tem libras como primeira língua, é bastante oralizada e possui boa leitura labial. Esses enunciados foram eliciados a partir de frases soltas e de um texto, em português, que continham diferentes tempos verbais, e também a partir de propagandas de TV, que seriam estímulos para a criação de possíveis pequenas histórias em libras ${ }^{69}$.

${ }^{67}$ Xavier (2006:82) chama a atenção para o fato de o dicionário de Capovilla \& Raphael (2001) possuir 1205 entradas lexicais das 4335 dessa primeira edição que representam traduções diferentes para sinais que são realizados da mesma maneira, ou seja, que possuem as mesmas propriedades articulatórias, pelo menos segundo a descrição dada pelo dicionário. Xavier propôs, em seu estudo, a construção de um banco de dados que permitisse o acesso aos sinais em libras por meio de suas propriedades articulatórias, o que, naquele momento, os autores do dicionário ainda não tinham feito, e o que evitaria esse tipo de redundância no registro dos itens lexicais da língua.

${ }^{68}$ A versão mais atual do dicionário é de 2012.

${ }^{69} \mathrm{O}$ texto em português, com diferentes tempos, que foi usado para eliciar esses dados, foi criado pela professora Evani Viotti (USP), para suas aulas de Elementos de Linguística da Faculdade de Filosofia, Letras e Ciências Humanas da USP. Entre as propagandas de TV apresentadas no teste, estão a do carro Ford Fusion, a do Honda City e a do Brilho Intense do Boticário, que serviram de estímulos para três textos selecionados para esta pesquisa. Para a realização desse experimento de eliciar dados, contei com a colaboração de Neiva de Aquino Albres e da colaboradora surda Regiane Agrella. 
A proposta desse experimento era a de ver alguns desses sinais dicionarizados que tinham sido levantados anteriormente em uso. O objetivo também foi verificar, em libras, possíveis embreagens de tempo que ocorrem em português. Por isso, havia frases que apresentavam esse tipo de mecanismo enunciativo entre os estímulos. Esse teste gerou alguns dos textos que ilustram partes desta tese e que foram analisados durante a pesquisa, como o texto "Sonhos", por exemplo, que será apresentado mais adiante. As propagandas foram ótimos estímulos, pois a partir delas, não só foi possível obter textos narrativos em libras como também textos mais didáticos, como foi o caso do texto em que a colaboradora ouvinte explica a propaganda a que assistiu, ao invés de narrar, a seu modo, os eventos ocorridos nesse texto comercial.

Não é possível, porém, avaliar o quanto, nesse experimento, as sinalizações em libras foram influenciadas pelo português. Dois casos são bastante curiosos e mostram tanto as dificuldades em obter dados por meio desse tipo de metodologia de eliciação a partir de uma língua oral. Apesar disso, os resultados obtidos nesse teste parecem mostrar, entre outros fatos interessantes, uma possível embreagem homocategórica de tempo em libras.

Nas figuras 29 e 30, abaixo, podemos ver dois exemplos de enunciados em libras, que apresentam sinalizações similares e que foram eliciados a partir de sentenças no português que apresentavam verbos em tempos diferentes. No exemplo em 29, a frase estímulo estava no presente. E, no exemplo em 30, no passado.

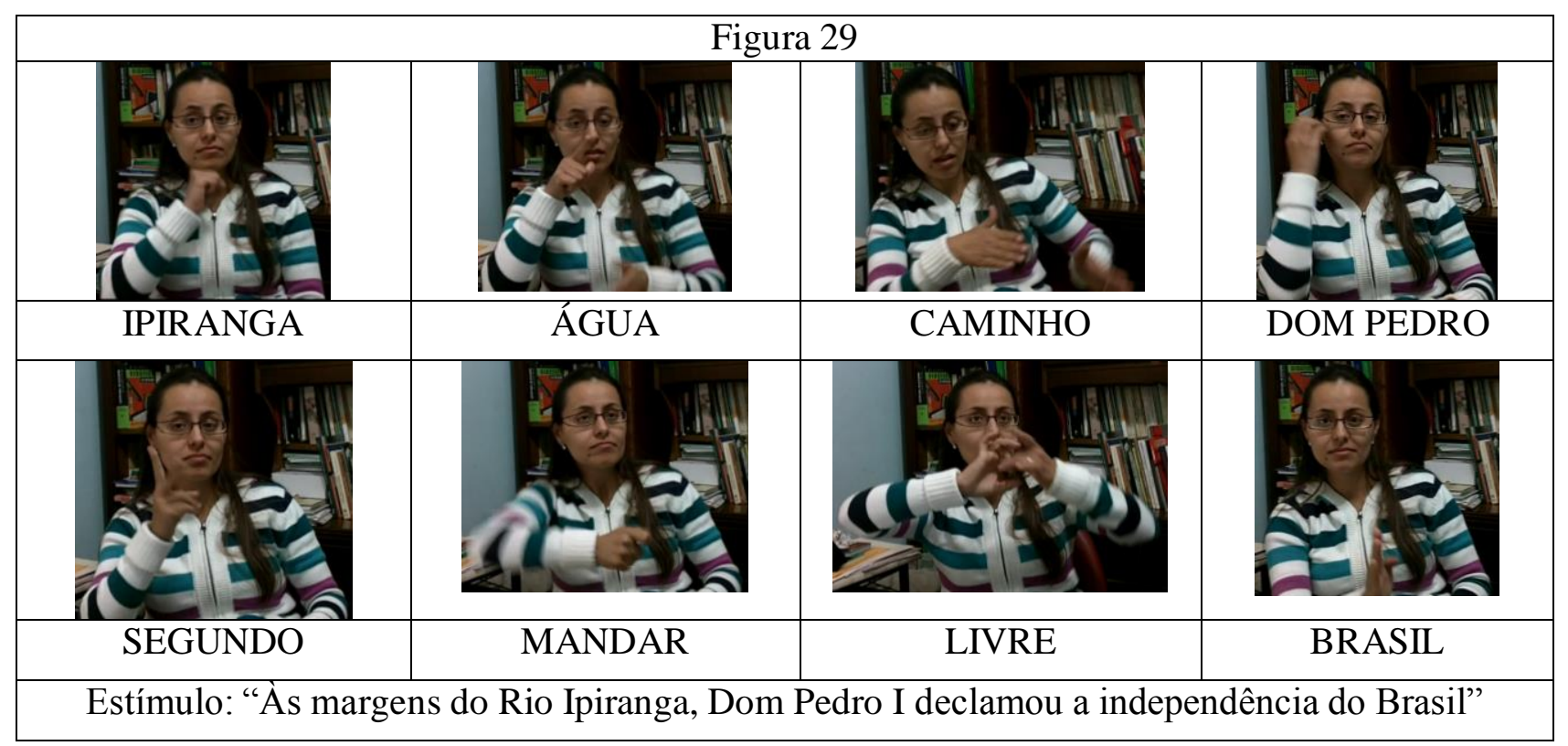




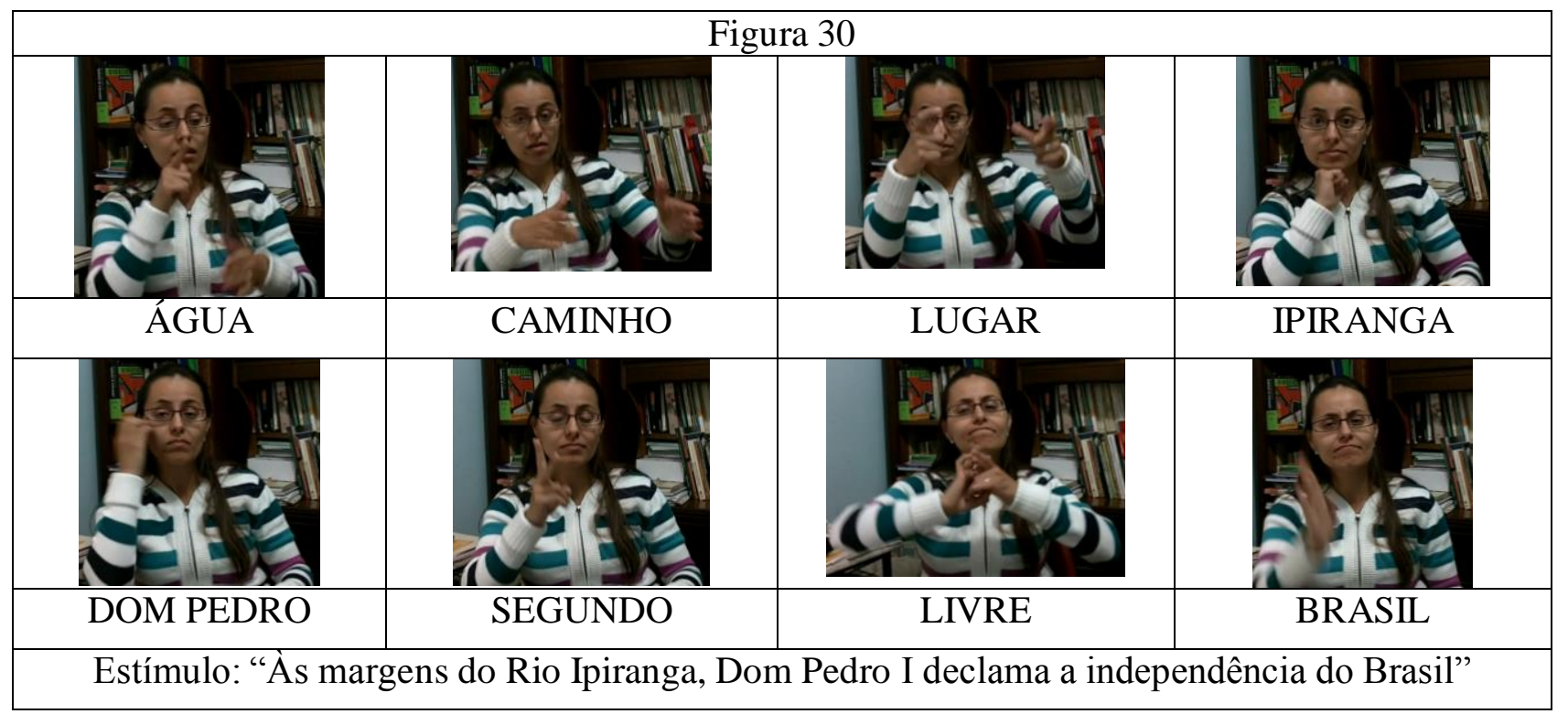

A única diferença entre a sinalização em 29 e em 30 é a ordem de apresentação dos elementos do cenário. No exemplo em 29 , estimulado pela sentença no presente, a sinalizadora apresenta, primeiramente, o rio, depois, o lugar onde ele se encontra, para, então, introduzir o sujeito da ação, Dom Pedro I, e a ação propriamente dita, que é libertar o Brasil. Nessa sinalização, não aparece o sinal para o que equivaleria, em libras, à ideia de declamar, nesse contexto. Mas é interessante notar que, ao compararmos os dois enunciados produzidos pela colaboradora, tanto seu tronco quanto a direção de seu olhar são muito parecidos. O corpo está levemente inclinado para a direita e para trás da sinalizadora, durante toda a sinalização, nos dois exemplos, e, em quase todos os sinais realizados, nos dois enunciados, é possível ver o olhar direcionado a sua interlocutária, no início, e, em outros momentos, desviado de onde estava a câmera, e, algumas vezes, até fechado. Comparando as duas sinalizações, a impressão é a de que os dois textos em libras apresentam o mesmo tempo, independentemente da diferença temporal que havia nas sentenças que serviram de estímulo a eles. A colaboradora não parece ter feito a distinção entre o passado e o presente, quando transformou os textos em português em textos em libras. Nos exemplos 29 e 30, a debreagem de pessoa e de espaço é enunciva, e o tempo parece ter sido neutralizado, nos dois casos.

Outro exemplo bastante interessante é o que surgiu na eliciação do futuro. A colaboradora ouvinte interpretou em libras a sentença do português "Amanhã te ligarei”, em que ocorre uma debreagem enunciativa de tempo, e, em seguida, "Amanhã te ligo", em que temos uma embreagem temporal enunciativa, pois há uma neutralização entre as formas de futuro e de 
presente. Em libras, as duas sentenças foram sinalizadas da mesma maneira, com o uso do sinal adverbial AMANHÃ, e o sinal para “telefonar” (TELEFONE) foi realizado do mesmo modo, nos dois casos, como mostram as figuras 31 e 32 , abaixo $^{70}$ :

\begin{tabular}{|c|c|c|}
\hline AMANHÂ & Figura 31 \\
\hline EStímulo: "Amanhã te ligarei" & TELEFONE \\
\hline
\end{tabular}

\begin{tabular}{|c|c|c|}
\hline & Figura 32 \\
\hline AMANHÂ & Estímulo: "Amanhã te ligo" & TELEFONE \\
\hline
\end{tabular}

Novamente, as duas sinalizações foram muito parecidas, independentemente da diferença temporal do português que apareceu nas frases que as estimularam. Podemos notar que, nos dois casos, os olhos da sinalizadora estão direcionados para frente, para sua interlocutária, e sua cabeça levemente inclinada para frente, desde o momento em que realiza o sinal AMANHÃ até o último sinal, nos dois exemplos. Aparentemente, os dois enunciados também parecem estar expressando o mesmo tempo, marcado pelo item lexical de futuro. É possível pensar, nesse caso, que a colaboradora também tenha realizado uma embreagem temporal homocategórica em seu texto em libras, uma vez que, mesmo usando o sinal AMANHÃ no início e marcando, assim, o

\footnotetext{
${ }^{70}$ Por se tratar de um sinal direcional, a marcação da segunda pessoa (para quem o enunciador ligará) é feita com o movimento e direcionamento das mãos ao realizarem TELEFONE.
} 
MR como futuro, ela faz uma distinção de tempo, ao gesticular com a boca e pronunciar "ligarei", no primeiro caso, e "ligo", no segundo, ao mesmo tempo em que sinaliza ${ }^{71}$.

No caso dos exemplos em 29 e 30, em que não há um item lexical com valor de advérbio marcando o tempo, fica muito difícil dizer que uma sentença está no futuro e a outra no presente, apenas observando a forma como a sinalizadora movimenta seu tronco e direciona o seu olhar. Nos exemplos em 31 e 30, a presença do advérbio AMANHÃ, nos dois enunciados, torna a diferenciação ainda mais difícil, pois, tirando a diferença de gesticulação feita pela boca, não há sinalizações distintas. Se os itens verbais da língua possuíssem um morfema flexional de tempo ou se qualquer um dos elementos como o movimento do corpo para trás ou para frente fossem de fato marcadores específicos de tempo, então, poderia ter ocorrido diferenças de sinalização para marcar o presente e o passado, nos exemplos 29 e 30, e não seria plausível considerar que houve uma embreagem de tempo, nos exemplos 31 e 32.

\subsection{2) Construção do corpus de textos em libras}

Diante das dificuldades encontradas nos testes de eliciação de enunciados em libras a partir de textos em português, a ideia passou a ser analisar histórias contadas pelos colaboradores de forma mais espontânea, com o mínimo de interferência do português possível, em que houvesse personagens e ações, e fosse possível ver diferentes tempos sendo instaurados. Usando diferentes estratégias para estimular as contações de história, pedimos a três diferentes colaboradores, fluentes em libras (dois surdos e uma intérprete da língua), para criar os textos com os quais poderia dar continuidade à investigação do tempo.

Selecionamos, entre os textos eliciados, cinco para compor o corpus que seria analisado com mais detalhes nesta pesquisa: dois textos em libras sinalizados a partir de uma história em quadrinhos sem falas, "História do Gibi 1" e "História do Gibi 2"; uma nova versão da história infantil com a qual trabalhei durante o mestrado, "O amor é surdo"; um texto que é a história de vida de sua sinalizadora, "Minha Vida"; um dos textos que foi eliciado a partir de um comercial de carro, "Sonhos"; e um dos textos selecionados da internet, "Metáfora - O escorpião e o

\footnotetext{
${ }^{71}$ Uma diferença que existe entre os dois enunciados em libras talvez seja o movimento da boca da sinalizadora, na realização do sinal TELEFONE. No exemplo em 31, fica claro que ela pronuncia "ligarei", em 32, "ligo". Essa oralização dos verbos, no entanto, não é necessária na realização do sinal em libras. Mas é interessante notar que a palavra dita em português acaba por diferenciar as sentenças, pelo menos, para os ouvintes para quem essa distinção entre o futuro e o presente é bastante relevante, pois é marcada morfologicamente nos verbos.
} 
príncipe". Os colaboradores fluentes em libras, que colaboraram com esta pesquisa, contando essas histórias, foram os surdos Celso Badin, Regiane Agrella e Rimar Segala, e a ouvinte, a Neiva de Aquino Albres. No DVD que acompanha esta tese, é possível assistir aos vídeos de cada uma dessas histórias. Segue, também, abaixo, a imagem de cada um dos sinalizadores dos textos escolhidos para esta pesquisa, para que seja mais fácil a identificação de cada um deles daqui em diante. $\mathrm{O}$ momento registrado nas fotos é o início de cada uma das histórias ${ }^{72}$ :

\begin{tabular}{|c|c|c|c|c|c|}
\hline $\begin{array}{c}\text { História do } \\
\text { Gibi } 1\end{array}$ & $\begin{array}{c}\text { História do } \\
\text { Gibi } 2\end{array}$ & $\begin{array}{c}\text { O Amor é } \\
\text { Surdo }\end{array}$ & Minha Vida & Sonhos & $\begin{array}{c}\text { Metáfora - O } \\
\text { escorpião e a } \\
\text { tartaruga }\end{array}$ \\
\hline $\overrightarrow{p e}$ & & & & & \\
\hline
\end{tabular}

Como foi dito, também foram analisados e se tornaram exemplos no trabalho outros textos em libras, eliciados durante os testes descritos na seção anterior, e aqueles que também estão disponíveis na Internet ${ }^{73}$. Dentre esses textos, estão os vídeos "Imaginação", "Dúvida", "Explicação" e "Aula de História", sinalizados também por Neiva, e "Sonho com um carro novo", também sinalizado pela surda Regiane ${ }^{74}$.

Inicialmente, preocupamo-nos em levantar, nesses textos escolhidos para o trabalho, os itens lexicais já dicionarizados e que fossem signos da língua que marcam tempo. Juntamente com esse levantamento, procuramos encontrar, ao transcrever e descrever o plano de expressão desses textos sinalizados, outros elementos linguísticos e discursivos que podem ser responsáveis pelas marcações de tempo e por toda a organização temporal dos eventos nessas histórias.

\footnotetext{
${ }^{72}$ Todos os textos analisados nesta pesquisa estão devidamente autorizados por seus autores. Novamente, agradeço a colaboração dos surdos Celso Badin e Regiane Agrella, e da pesquisadora e intérprete de libras, Profa. Dra. Neiva Albres (UFSC) para esta pesquisa. À Neiva, agradeço não só pelos textos que criou e que disponibilizou para este trabalho, mas também pelas conversas sobre o tempo na língua. Aproveito para agradecer os colegas de pesquisa Thaís Bolgueroni e André Xavier por toda ajuda e parceria, no dia das filmagens dos textos analisados nesta tese, e a Rimar Segala, pela colaboração com os trabalhos de pesquisa do LLIC

${ }^{73}$ Esses textos também se encontram no DVD, no anexo 3.

${ }^{74} \mathrm{O}$ texto "Imaginação" foi eliciada a partir da propaganda sobre o Brilho Intense do Boticário (acesso pelo link: https://www.youtube.com/watch? $=$ WbNSYPgHK7c); os textos "Dúvida" e "Explicação", a partir do comercial sobre o carro Honda City - Casamento (acesso pelo link: https://www.youtube.com/watch?v=1dxdxDzmM04) .
} 
A seguir, comentamos, com mais detalhes, como cada um dos textos que formam o corpus desta pesquisa foram eliciados e filmados.

\subsubsection{1) "História do Gibi 1" e "História do Gibi 2"}

O texto "História do Gibi 1" foi contado pelo colaborador surdo Celso Badin a um intérprete, fluente em libras, em frente a duas câmeras de vídeo (uma que foi responsável pela tomada do corpo inteiro do sinalizador e a outra, que fez a tomada do rosto de Celso) ${ }^{75}$. A história foi sinalizada a partir de uma história em quadrinhos da Turma da Mônica, que se chama "Não chora que eu dou um jeito" e que é composta apenas por imagens, sem balões de fala entre as personagens ${ }^{76}$. O enredo é formado por muitas ações diferentes, realizadas por quatro personagens (Cebolinha, Magali, Cascão e Marina), em diferentes momentos e locais. A ideia foi estimular uma história contada em libras naturalmente, sem influência da língua oral.

A história sinalizada por Celso se constitui como um novo texto. Alguns elementos do nível narrativo, no entanto, são muito parecidos nessas duas histórias (em quadrinhos e em libras), mas há diferenças significativas, tanto no nível discursivo como no nível fundamental entre elas. A transcrição da linha da tradução do texto sinalizado se encontra anexada a esse relatório e, por ela, é possível perceber a existência de uma nova história, intitulada, por esse motivo, também de forma diferente da história em quadrinhos que a inspirou.

Na tabela a seguir, é possível ler a história original, de Maurício de Souza:

${ }^{75} \mathrm{O}$ intérprete para quem Celso contou a "História do Gibi 1"foi Alexandre Guimarães.

${ }^{76}$ Essa história que serviu de estímulo para o texto de Celso Badin encontra-se no "Almanaque de historinhas sem palavras", de Maurício de Souza. 


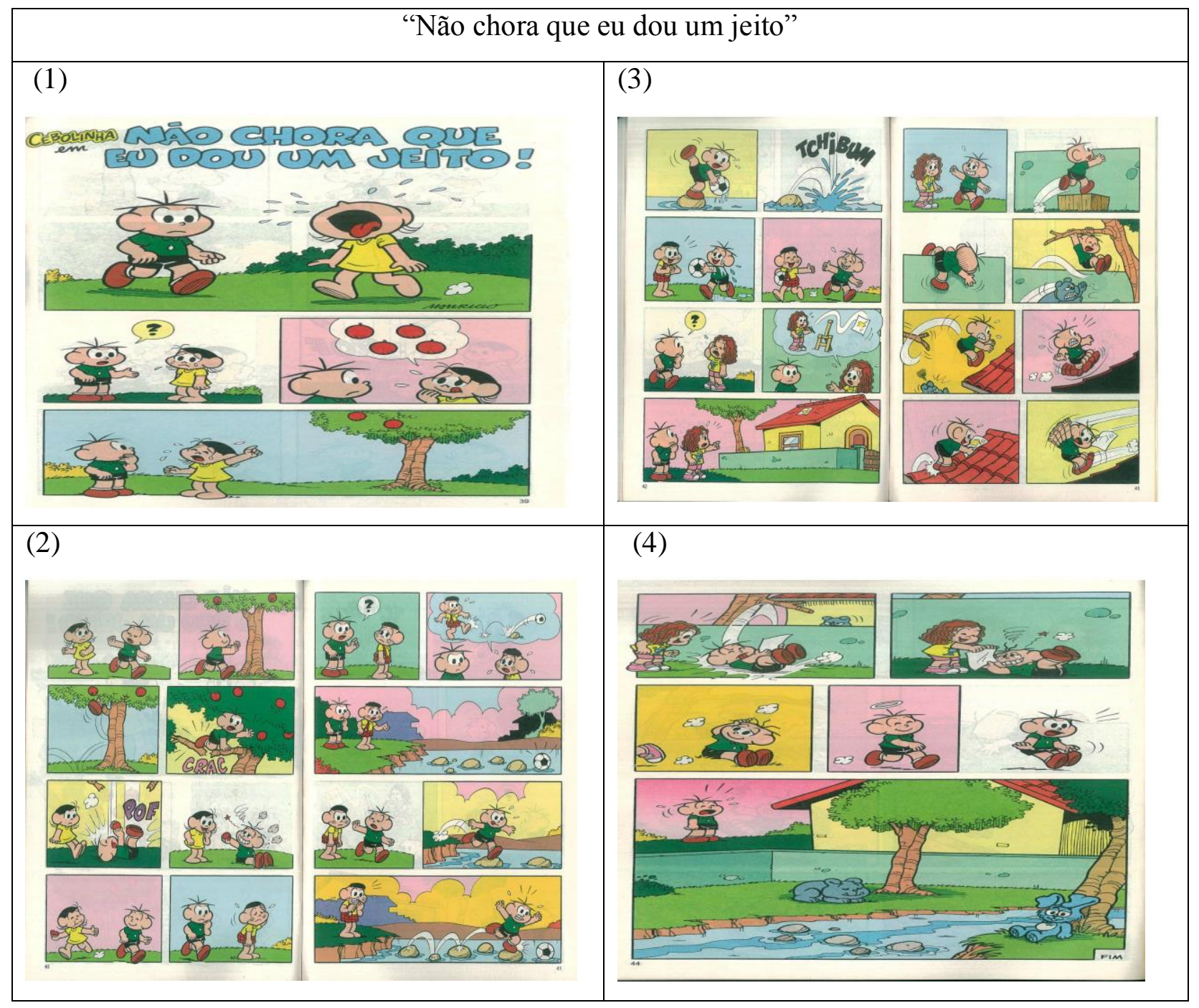

Depois de ler a história em quadrinhos acima, Celso criou o seu próprio texto, contado em 00:02:48:000 (dois minutos e quarenta e oito segundos). A "História do Gibi 1" também é sobre o Cebolinha, que resolve ajudar todos os amigos que encontra em seu caminho ${ }^{77}$. O vídeo desse

\footnotetext{
${ }^{77}$ Segue, aqui, um resumo da história contada por Celso Badin. Primeiramente, Cebolinha encontra a Magali que, aos prantos, conta que quer uma maçã de uma árvore. Ela diz que está com fome e que não consegue alcançar a fruta para pegá-la. Cebolinha não mede esforços para ajudá-la. Ele sobe na árvore, desequilibra-se, consegue, depois de muito sufoco, pegar a maçã, mas o galho em que está quebra e ele acaba caindo da árvore. Depois de entregar a maçã à Magali, Cebolinha encontra o Cascão, que também está chorando. Cascão conta-lhe que estava jogando bola e que, depois de um chute forte, a bola foi parar no meio do lago que havia ali perto. Como tem medo de água, Cascão não conseguira resgatar sua bola. Cebolinha, então, enfrenta mais esse desafio, tenta alcançar a bola, pulando em algumas pedras, mas de novo se desequilibra e acaba caindo na água. Molha-se todo, mas consegue pegar a bola para o Cascão. Mesmo dolorido e molhado, Cebolinha ajuda sua amiga Marina, que também encontra chorando. A menina está triste, porque um vento tinha levado a folha na qual estava desenhando. A folha foi parar em cima do telhado de uma casa. A casa era cercada por um muro. Quando Cebolinha sobe no muro, para poder alcançar o telhado, percebe que há um cachorro bravo ali. Para escapar de uma mordida, o garoto se apoia no galho de uma árvore e pula no telhado. Depois de pegar o desenho da Marina, Cebolinha acaba caindo no chão e se machucando ainda mais. A Marina fica muito feliz e agradece a ajuda. No final, Cebolinha acaba encontrando o coelhinho da Mônica, o Sansão. Mas o coelhinho está em um lugar tão difícil, que o garoto acaba desistindo.
} 
texto sinalizado pode ser dividido em seis grandes partes, que podem servir de ponto de partida para a análise que será apresentada no próximo capítulo. Na tabela a seguir, nomeamos cada uma dessas partes e descrevo, resumidamente, o que acontece em cada uma delas.

\begin{tabular}{|c|c|c|}
\hline Partes do vídeo da "História do Gibi 1" & Descrição do evento central & Intervalo de tempo \\
\hline Preparação para a contação & $\begin{array}{l}\text { O sinalizador aguarda o sinal da } \\
\text { pesquisadora para iniciar a } \\
\text { contação. Há interação entre eles. }\end{array}$ & 00:00:00:000 a 00:00:03:000 \\
\hline Início da história & $\begin{array}{l}\text { Narrador explica para seu } \\
\text { narratário que história irá contar. }\end{array}$ & 00:00:03:000 a 00:00:09:000 \\
\hline Título & $\begin{array}{l}\text { Narrador diz qual é o título da } \\
\text { história. }\end{array}$ & 00:00:09:000 a 00:00:17:000 \\
\hline Cena 1: Magali & $\begin{array}{l}\text { Narrador conta o encontro do } \\
\text { Cebolinha com a Magali. Ocorre } \\
\text { um diálogo entre os dois. São } \\
\text { narradas as ações realizadas pelo } \\
\text { Cebolinha. }\end{array}$ & 00:00:17:000 a 00:00:51:000 \\
\hline Cena 2: Cascão & $\begin{array}{l}\text { Narrador conta o encontro do } \\
\text { Cebolinha com o Cascão. Ocorre } \\
\text { um diálogo entre os dois. São } \\
\text { narradas as ações realizadas pelo } \\
\text { Cebolinha. }\end{array}$ & 00:00:51:000 a 01:29::000 \\
\hline Cena 3: Marina & $\begin{array}{l}\text { Narrador conta o encontro do } \\
\text { Cebolinha com a Marina. Ocorre } \\
\text { um diálogo entre os dois. São } \\
\text { narradas as ações realizadas pelo } \\
\text { Cebolinha. }\end{array}$ & 00:01:29:000 a 00:02:20:000 \\
\hline Cena 4: Coelhinho & $\begin{array}{l}\text { Narrador conta que o Cebolinha } \\
\text { encontra o coelhinho da Mônica e } \\
\text { desiste da aventura de pegá-lo. }\end{array}$ & 00:02:20:000 a 00:02:45:000 \\
\hline Volta ao contexto de filmagem & $\begin{array}{l}\text { Sinalizador aguarda alguma } \\
\text { resposta da pesquisadora. }\end{array}$ & 00:02:45:000 a 00:02:46:000 \\
\hline FIM & $\begin{array}{l}\text { Narrador finaliza a história, } \\
\text { sinalizando FIM. }\end{array}$ & 00:02:46:000 a 00:02:47:000 \\
\hline Término da contação da história & Sinalizador sorri para a câmera. & 00:02:47:000 a 00:02:48:000 \\
\hline
\end{tabular}


Para verificar como outro usuário de libras poderia criar as mesmas relações temporais presentes nos quadrinhos, filmamos uma colaboradora surda, Regiane Agrella, contando a mesma história. Ela leu o texto da Turma da Mônica, antes de iniciar o seu, e não teve, em nenhum momento, acesso à história sinalizada por Celso. A ideia era a de que Regiane não fosse influenciada, nem pelo português nem pela sinalização de outro surdo. Novamente, surgiu um novo texto que, por ser diferente e ter recebido o mesmo estímulo do primeiro, foi intitulado "História do Gibi 2".

Regiane contou sua história do Cebolinha para um amigo ouvinte, que tem um bom domínio de libras ${ }^{78}$. O texto dela tem 00:02:22:000 (dois minutos e vinte e dois segundos) e foi filmado com apenas uma câmera de vídeo.

\subsubsection{2) "O amor é surdo"}

O texto "O amor é surdo", que também será descrito e analisado neste trabalho, foi contado pelo surdo Celso Badin e eliciado a partir de outra história, em libras, também intitulada "O amor é surdo". O texto original, que serviu de estímulo para a história de Celso, foi criado pela colaboradora surda, Sylvia Lia, e pela pesquisadora, durante a pesquisa de mestrado (Moreira, 2007), para o estudo dos pronomes pessoais e dos verbos indicadores em uso ${ }^{79}$. Tratase de uma história infantil, muito simples, com muitas personagens fantásticas ${ }^{80}$.

A ideia foi obter um texto, sem influência de um ouvinte e sem a exigência de que houvesse determinados sinais, como pronomes ou verbos indicadores, durante a contação, como foi o caso da primeira história, de Sylvia Lia. O resultado foi um texto sinalizado, baseado em

\footnotetext{
${ }^{78}$ Nessa filmagem, André Xavier foi o interlocutário de Regiane Agrella, durante a contação de "História do Gibi 2".

${ }^{79}$ A elaboração da história foi feita da seguinte maneira. Primeiro, preparamos uma lista de verbos indicadores e de pronomes pessoais e a apresentamos para a colaboradora Sylvia Lia. Pedimos, então, que ela criasse uma história que usasse todos aqueles verbos e pronomes. Fomos, então, passo a passo, construindo cada um dos momentos do texto, tentando usar a maior quantidade de sinais de apontamento possível. Foram feitas três filmagens e selecionada a sinalização mais natural.

${ }^{80} \mathrm{~A}$ história é sobre um bebê surdo, que é abandonado pela mãe e adotado por uma camponesa. O bebê cresce e se torna uma linda moça que trabalha na roça. Um dia essa moça vai vender verduras na feira do reino e encontra um príncipe. Os dois se apaixonam. O príncipe deseja se casar com a moça do campo, mas a rainha, sua mãe, diz que as leis não permitem rainhas ou reis surdos. A empregada do castelo ouve a conversa entre o príncipe e sua mãe, e diz ao moço que uma fada pode ajudá-lo. O príncipe, então, vai até o castelo da fada e pede que ela transforme todas as pessoas ouvintes do reino em pessoas surdas. A fada pede a ele algo em troca: a libertação de seu marido, que está no castelo da bruxa. O príncipe vai até o castelo da bruxa, para libertar o marido da fada, e convence a malvada a soltar o prisioneiro. Feito isso, ele volta ao castelo da fada para que ela realize seu pedido e, assim, ele, surdo, possa se casar com sua amada. A fada enfeitiça o reino e o príncipe pede a moça do campo em casamento. Durante a cerimônia de matrimônio, uma rainha de um reino distante aparece e revela que é a mãe da moça surda e pede perdão a sua filha. E todos vivem felizes para sempre.
} 
uma história contada em libras, que também ganhou características discursivas próprias, diferentes, em parte, do texto original.

O novo texto "O amor é surdo" se diferencia do texto que o estimulou em alguns aspectos do nível discursivo, em especial, no que se refere à figurativização. A maneira como Celso cria as personagens e demonstra suas ações difere do jeito como a Sylvia Lia sinalizou todos esses elementos da história, mas o enredo das duas é quase o mesmo. A filmagem de Celso foi realizada com o intuito de atender pelo menos duas pesquisas de imediato: o trabalho sobre a referenciação de pessoa, de Bolgueroni (2013), e este estudo sobre o tempo em libras.

O texto "O amor é surdo" de Celso é contado em 00:07:33:000 (sete minutos e trinta e três segundos) e também foi filmado por duas câmeras de vídeo, e, portanto, com duas tomadas: do corpo inteiro e do rosto do sinalizador ${ }^{81}$.

\subsubsection{3) "Minha Vida"}

O texto "Minha Vida" foi sinalizado pela pesquisadora e intérprete de libras Neiva de Aquino Albres. O vídeo tem 00:03:29:000 (três minutos e vinte e nove segundos) e conta a história de vida dela. Para obter esse texto, pedimos que ela contasse como conheceu o marido. Nossa interação inicial foi em português. A sinalização analisada foi filmada apenas uma vez, no escritório da casa dela, por uma única câmera de vídeo.

\subsubsection{4) "Sonhos"}

O texto "Sonhos" também foi sinalizado por Neiva, em seu escritório, com uma câmera que fez a tomada do corpo da sinalizadora. Pedimos que a colaboradora assistisse a um comercial de TV do carro Ford Fusion ${ }^{82}$, que selecionamos para o trabalho, e nos contasse a história presente nessa propaganda.

\footnotetext{
${ }^{81}$ O texto "O amor é surdo", contado pelo surdo Celso Badin, foi transcrito por Bolgueroni (2013). A pesquisadora, a quem agradeço imensamente, disponibilizou a sua transcrição do texto para o uso desta pesquisa.

${ }^{82}$ Pode-se assistir à propaganda do carro Ford Fusion, que estimulou o texto "Sonhos" em https://www.youtube.com/watch?v=YzZZHsoTDck. Essa mesma propaganda serviu de estímulo para o texto sinalizado por Regiane Agrella e intitulado "Sonho com um carro novo".
} 
O texto em libras criado por Neiva também possui características próprias, diferenciandose, assim, em alguns momentos do texto que o estimulou. A história filmada possui 00:00:48:000 (quarenta e oito segundos).

\subsubsection{5) "Metáfora - O escorpião e a tartaruga"}

O texto "Metáfora - O escorpião e a tartaruga" foi criado pela Cia. Arte e Silêncio e assinam a obra Rimar R. Segala e Sueli Ramalho. O vídeo possui 00:05:38:000 (cinco minutos e trinta e oito segundos) e se encontra disponível on-line, no canal de Rimar, no youtube na Internet e, também, no DVD que acompanha este trabalho ${ }^{83}$.

Nesse texto, Rimar explica o conceito de metáfora existente na história do escorpião e da tartaruga. Primeiramente, ele comenta a dificuldade que seu pai teve em entender o conceito de metáfora. E, em seguida, ele conta uma história sobre sua irmã, em que o conceito ficou mais claro, quando ela ouviu uma fábula. Trata-se da história do escorpião que convence uma tartaruga a atravessar o rio com ele nos cascos. O escorpião promete não picá-la e a persuade de que não faria mal a ela, pois, se não, os dois morreriam afogados. A tartaruga acredita nele e os dois começam a travessia. Antes de chegar à outra margem do rio, o escorpião pica e mata a tartaruga. Antes, porém, diz que não pôde evitar sua própria natureza ${ }^{84}$.

\section{2) A transcrição dos dados no ELAN}

Para descrever e analisar os textos em libras selecionados para este trabalho, foi necessário transcrevê-los. Como já foi dito, no capítulo anterior, a ideia desta pesquisa foi a de olhar para um conjunto de possíveis marcadores temporais e, portanto, o método de descrição precisou ser bastante detalhista, para considerar tantos os gestos produzidos pelas mãos como também os movimentos, a localização do tronco e das mãos e a direção do olhar dos sinalizadores.

A transcrição de uma língua visual não é trivial. A forma de registrá-la é tema de projetos de pesquisa. Afinal, trata-se de uma língua com escrita ainda em desenvolvimento, e, portanto,

\footnotetext{
${ }^{83}$ Este texto pode ser acessado também pelo seguinte sítio: https://www.youtube.com/watch? $v=q H Z D p P p s 9 Z g$. O vídeo já está autorizado para o uso do grupo de pesquisa LLIC em pesquisas acadêmicas

${ }^{84}$ Muitos conhecem essa fábula contada por Rimar na versão “O sapo e o escorpião”, de Esopo.
} 
todas as informações que precisam ser notadas, assim como as glosas dos sinais, acabam sendo realizadas em alguma língua oral. Para transcrever os textos sinalizados, é preciso um sistema de transcrição que consiga capturar todos os aspectos da gestualidade do sinalizador e possa ajudar a compor um banco de dados da língua que possibilite a descrição completa da gramática e do discurso em libras.

A primeira etapa do trabalho de transcrição foi converter os arquivos provenientes das filmagens em arquivos de formado mpeg, compatível com o software que auxilia a transcrição, o ELAN (EUDICO Language Annotator) ${ }^{85}$. Criado pelo Instituto Max Planck de Psicolinguística e usado para análises linguísticas diversas, o ELAN permite sincronizar as imagens em vídeo com anotações, para os registros dos diferentes elementos que compõem um texto: linguagem verbal e gestos, ou sinalizações (sinais manuais e sinais não-manuais).

Abaixo, na figura 33, pode-se observar uma imagem de um trecho do texto "História do Gibi 1", que foi transcrito no ELAN.

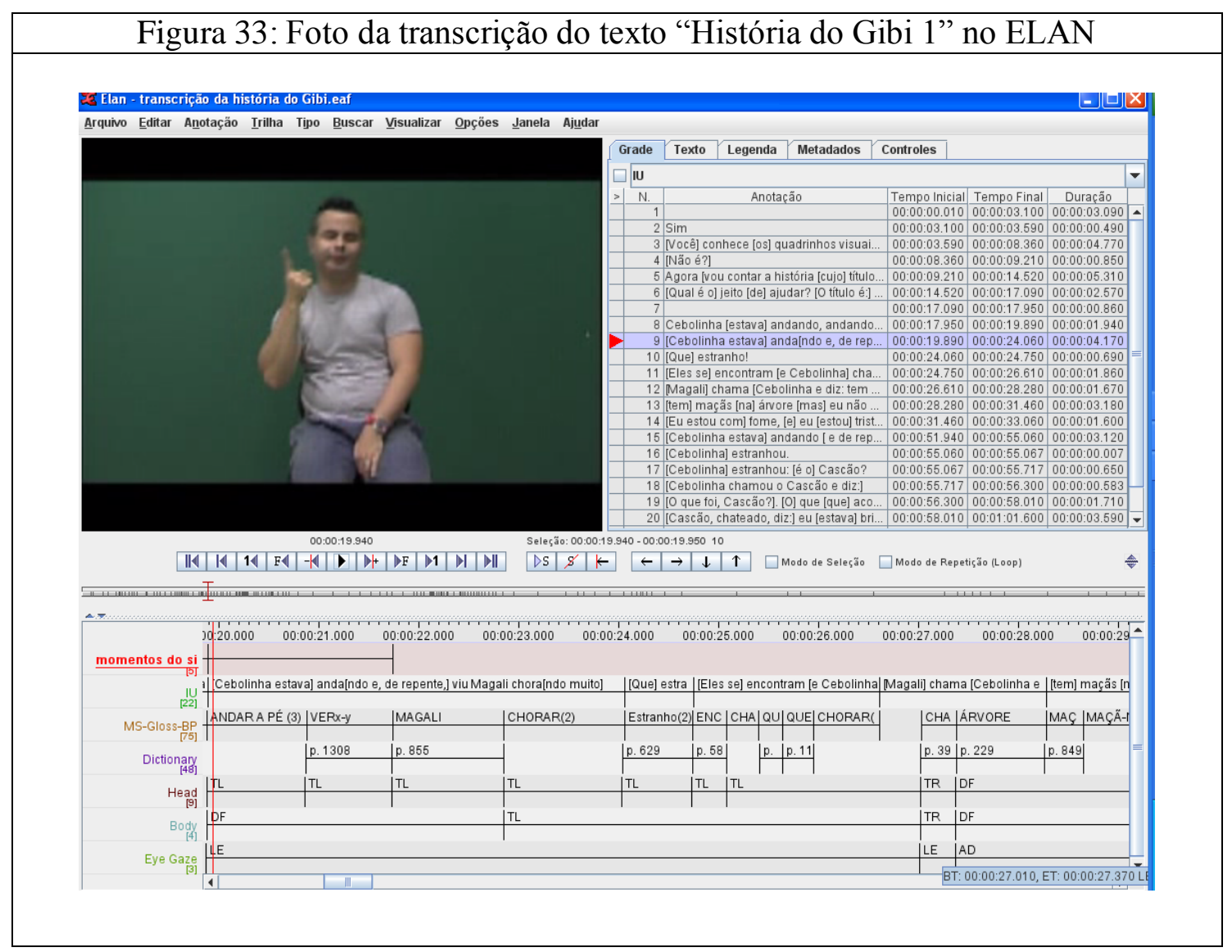

${ }^{85}$ Agradeço a Danilo Carlos pela ajuda com a conversão dos vídeos para o uso do ELAN. Como já foi dito, esse software pode ser baixado, gratuitamente, da internet por meio do sítio: http://www.mpi.nl/tools/elan.html. 
Os textos selecionados para a pesquisa foram transcrito com base no modelo de transcrição desenvolvido por McCleary \& Viotti (2007) e McCleary, Viotti \& Leite (2010) ${ }^{86}$. A ideia do grupo de pesquisa do LLIC tem sido a de segmentar o fluxo da história, primeiramente, em pequenos blocos entonacionais (IUs - Intonation Unit), seguindo as ideias de Chafe (1980 e $1994)^{87}$.

O processo de transcrição de McCleary, Viotti \& Leite (2010) é constituído principalmente de (i) uma segmentação em unidades entonacionais; (ii) uma glosa ou nome dos sinais manuais ${ }^{88}$; (iii) uma transcrição dos sinais não-manuais - sobrancelhas; olhos; boca; cabeça, e tronco; (iv) uma descrição dos sinais simultâneos, e (v) uma tradução para o português ${ }^{89}$. No anexo 1 deste trabalho, como já foi dito, é possível verificar o texto "História do Gibi 1" transcrito, com essa primeira segmentação em unidades entonacionais, traduzidas para o português.

A principal preocupação, para este trabalho, foi, desde o início, fazer o registro do olhar e do movimento do tronco e da cabeça do sinalizador, uma vez que são esses gestos que também parecem marcar a passagem de um nível enunciativo a outro e as diferenças entre debreagens de primeiro e de segundo graus presentes em toda a história ${ }^{90}$. Essa descrição se intensificou à medida que entramos em contato com outros estudos sobre as línguas de sinais, que já apontam toda essa gestualidade como sendo responsável pela marcação de tempo nos textos (ver Friedman, 1975; Amaral, Coutinho \& Martins, 1994; Finau, 2004; Mintz, 2005; Johnston \& Schembri, 2007; Meir \& Sandler, 2008; Sinte, 2013).

\footnotetext{
${ }^{86}$ Esse sistema de transcrição vem sendo aplicado por todos os membros do grupo de pesquisa LLIC da USP. O modelo toma como objeto o texto "História da Pera", contado pelo surdo Alexandre Melendez. Os autores partiram das ideias de Chafe (1980) e gravaram a contação de várias histórias, em línguas orais e em línguas de sinais, para analisar diversos aspectos da gramática e do discurso. Os textos foram eliciados a partir do filme História da Pera (Pear Story), que consta apenas de imagens e fundo musical, sem diálogos, que foi produzido sob a coordenação de Chafe, em meados dos anos 70. Algumas filmagens do acervo do grupo LLIC, em línguas de sinais, foram transcritas por Thaís Bolgueroni, em seu projeto de iniciação científica (ver Bolgueroni, 2007).

${ }^{87}$ A ideia de Chafe (1980 e 1994) é a de que os discursos não ocorrem em um fluxo contínuo, mas sim, em jatos de língua (McCleary, Viotti \& Leite, 2010). Estabelecer os limites dessas IUs não é simples. Para um estudo sobre a segmentação do discurso em libras, ver Leite (2008).

${ }^{88}$ Para padronizar os nomes dos sinais, a ideia é a de usar, como referência, o dicionário de Capovilla \& Raphael (2001). A glosa dos sinais manuais, então, vem se constituindo da palavra que aparece no verbete do dicionário.

${ }^{89} \mathrm{Tem}$-se usado colchetes entre as palavras do português, quando elas não correspondem a um sinal em libras, ou quando essas palavras são necessárias para uma boa formação do texto em português (McCleary, Viotti \& Leite, 2010). Isso também pode ser observado em minha transcrição.

${ }^{90}$ No DVD que acompanha este trabalho, é possível ver as transcrições de a "História do Gibi 1" e "O amor é surdo".
} 
Para a análise dos textos selecionados, optamos por criar mais duas trilhas de transcrição, além das que já existem no modelo desenvolvido por McCleary, Viotti \& Leite (2010): a dos níveis enunciativos e a dos sistemas temporais que são instaurados ao longo da história (na figura 33, essas trilhas aparecem logo no início do campo das anotações). Com a primeira trilha, conseguimos mapear os enunciados do narrador da história e as falas das personagens, que aparecem nos diálogos. Com a segunda trilha, foi possível descrever os sistemas temporais internos que compõem o texto.

Nas trilhas da descrição da cabeça, olhos e tronco, também é possível observar algumas siglas do vocabulário controlado (em inglês), que foi criado pelo grupo de pesquisa do LLIC. Na figura 33, acima, é possível notar que, na trilha da cabeça, por exemplo, durante a sinalização do sinal que aparece na imagem, ANDAR A PÉ (3), temos, na trilha da cabeça (Head) a sigla $t l$ (tilted left), para indicar que a cabeça do sinalizador está inclinada para a esquerda.

Na figura 34, abaixo, é possível ver, nessa imagem de um dos trechos da transcrição de "O amor é surdo", feita por Bolgueroni (2013), o momento em que o sinalizador realiza o sinal PASSADO. Notamos que, na trilha que descreve a direção do olhar (eye gaze - 1), aparece a seguinte notação: ul (eyes look up and left), para indicar que os olhos do sinalizador estão voltados para cima e para a esquerda, enquanto realiza o sinal manual que indica passado. São essas informações, em especial, sobre os movimentos do corpo e a direção do olhar, que auxiliaram na descrição e na análise do tempo em libras apresentadas no próximo capítulo. 


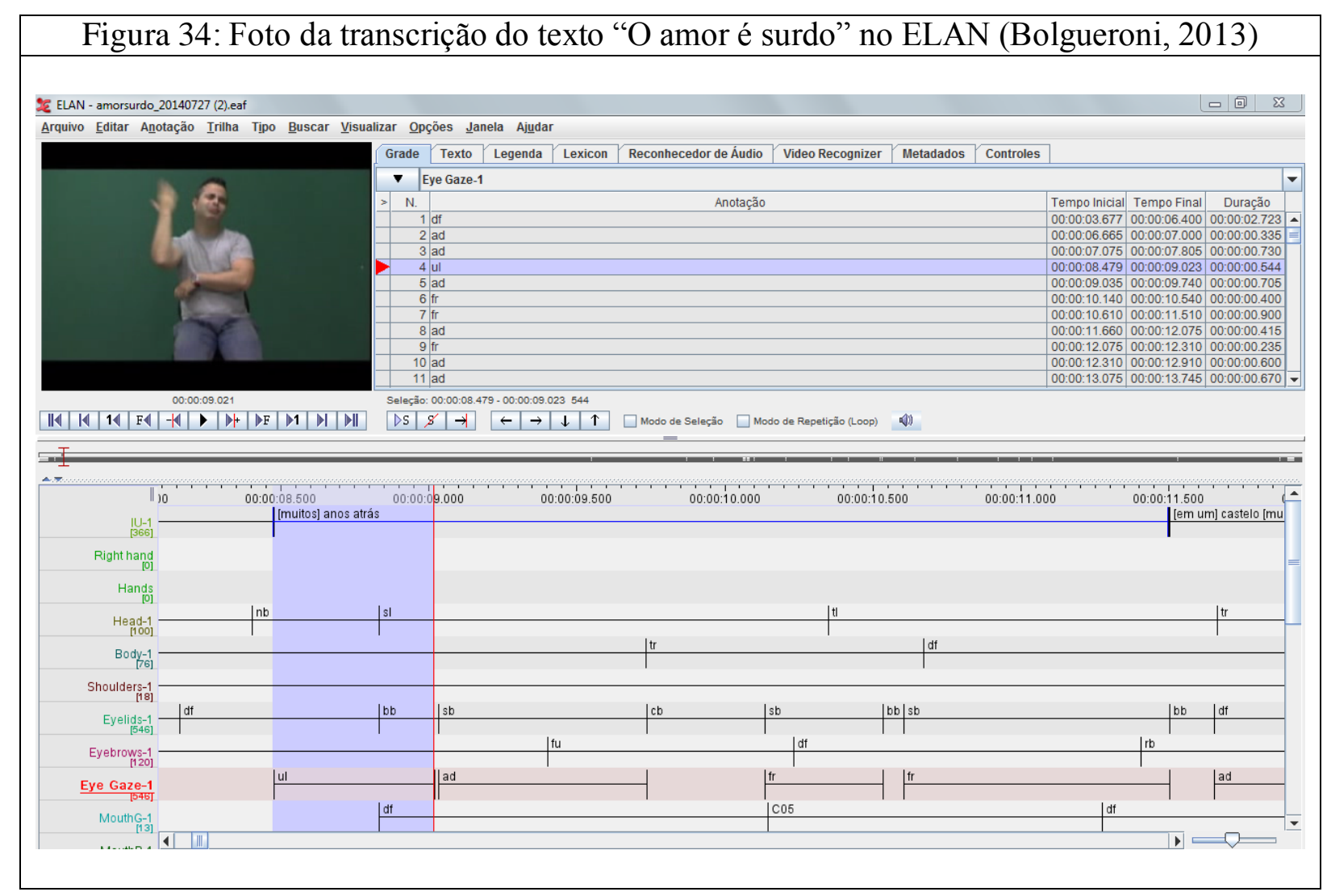

\section{3) Proposta de segmentação dos textos}

Para fazer a descrição do tempo a partir dos textos do corpus desta pesquisa, o primeiro passo foi fazer uma proposta de segmentação das histórias analisadas em nível da narração e nível do narrado, quando isso foi necessário e relevante para o estudo. Para fazer essa segmentação de um texto em dois níveis enunciativos, é preciso levar em conta as marcas discursivas para isso. Dentre os textos do corpus, verificamos em qual deles essas duas instâncias do discurso estão mais explícitas nos enunciados. Entre os textos selecionados, a "História do Gibi 1" e "Metáfora - O escorpião e a tartaruga" foram os que exigiram essa segmentação, uma vez que apresentam explicitamente essas duas instâncias enunciativas em sua realização ${ }^{91}$.

A transcrição no ELAN foi extremamente importante para cumprir todas as etapas do trabalho de descrição. Por se tratar de uma língua gestual, o trabalho descritivo se preocupou não só com as mãos dos sinalizadores e com a identificação dos itens lexicais que marcam tempo,

91 O texto "História do Gibi 2" também apresenta os níveis da narração e do narrado explicitados, mas essa segmentação apresentada para os textos "História do Gibi 1" e "Metáfora - O escorpião e a tartaruga". Essa segmentação, no entanto, não foi registrada. 
muitos até já dicionarizados em Capovilla \& Raphael (2001), como foi mostrado anteriormente, mas também com outros aspectos da gestualidade que manifesta os enunciados na língua ${ }^{92}$.

A transcrição consegue mostrar, com mais precisão e detalhes, por exemplo, os momentos exatos, nos textos, em que ocorre uma mudança na direção do olhar, da localização das mãos no espaço, os movimentos de cabeça e de corpo do sinalizador que indicam, entre outras coisas, por exemplo, a pessoa, o espaço e o tempo. Depois da trilha da glosa, a preocupação, então, foi a de descrever esses aspectos de cada um dos discursos analisados. Além disso, foi possível verificar que marcas indicam a passagem de um nível enunciativo para outro do texto. Para isso, foram criadas duas trilhas no modelo, para mostrar como essas duas instâncias enunciativas foram manifestadas nos textos: (i) a do nível da narração da história, em que são projetados o narrador e o narratário; (ii) a do nível do narrado, em que é contada a história propriamente dita ${ }^{93}$.

Como foi dito, um dos textos escolhidos para essa tarefa foi "História do Gibi 1", pois nele podemos verificar, por exemplo, as marcas da projeção do narrador logo no início da história. Também se pode identificar essas marcas dos níveis enunciativos nos demais textos analisados, mas não tão claramente como neste primeiro. No texto "História do Gibi 1", o nível da narração é aquele em que ocorre um simulacro do momento da enunciação e o narrador se projeta em primeira pessoa, ao se dirigir a um $t u$, explicitamente, como será mostrado mais adiante, e o nível do narrado é aquele que é composto pelos enunciados que formam a história de Cebolinha e seus amigos. Com a transcrição, ficou mais fácil notar que a fala do narrador parece se apresentar, então, de duas maneiras nesse texto: (i) quando o narrador interage com seu narratário (dirige-se a quem está a sua frente, acompanhando a história); (ii) quando o narrador conta a história a esse narratário, e, nesse momento, instaura, então, os atores do enunciado, do narrado (projeta no enunciado a terceira pessoa).

\footnotetext{
${ }^{92} \mathrm{Como}$ foi dito, tradicionalmente, nos estudos sobre as línguas de sinais, sinais e gestos são distintos. Movimento do tronco, direção do olhar, da cabeça são considerados parte da gramática por muito pesquisadores, mas continuam sendo chamados de "gestos". São chamados de sinais aqueles movimentos com as mãos, combinados ou não por expressões faciais ou da boca, que são convencionais na comunidade surda e dicionarizados. Para a semiótica, é desnecessária essa distinção, uma vez que ela considera que o plano de expressão das línguas sinalizadas é todo gestual.

${ }^{93}$ Como foi dito no capítulo 1 , todo texto é composto por muitas vozes discursivas. Temos uma voz, responsável por tudo que está sendo contado, que é sempre um $e u$, um enunciador, que cria um $e u$ narrador, que pode ou não estar explícito no enunciado, e que pode ou não se projetar como um $e u$, e, eventualmente, as vozes das personagens da história. São, portanto, diferentes instâncias enunciativas que se sobrepõem, e podem se sincretizar, ou seja, podem ser concretizadas por um único ator, da enunciação e do enunciado.
} 
Na figura 35, abaixo, podemos perceber que, antes de a história começar, o sinalizador, primeiro, interage com a pesquisadora, por meio de um aceno de cabeça, para confirmar que está pronto para começar a contar a história. Nesse momento, seu tronco está direcionado para frente, para o local onde, na sala, estava posicionada a câmera filmadora. Ele acena (faz o gesto de "sim" com a cabeça) e, em seguida, vira o tronco e a cabeça para sua esquerda, para interagir com o intérprete Alexandre, para quem ele vai contar a história. Pode-se dizer que, nesse instante, se instaura o narrador e o texto que está sendo analisado começa.

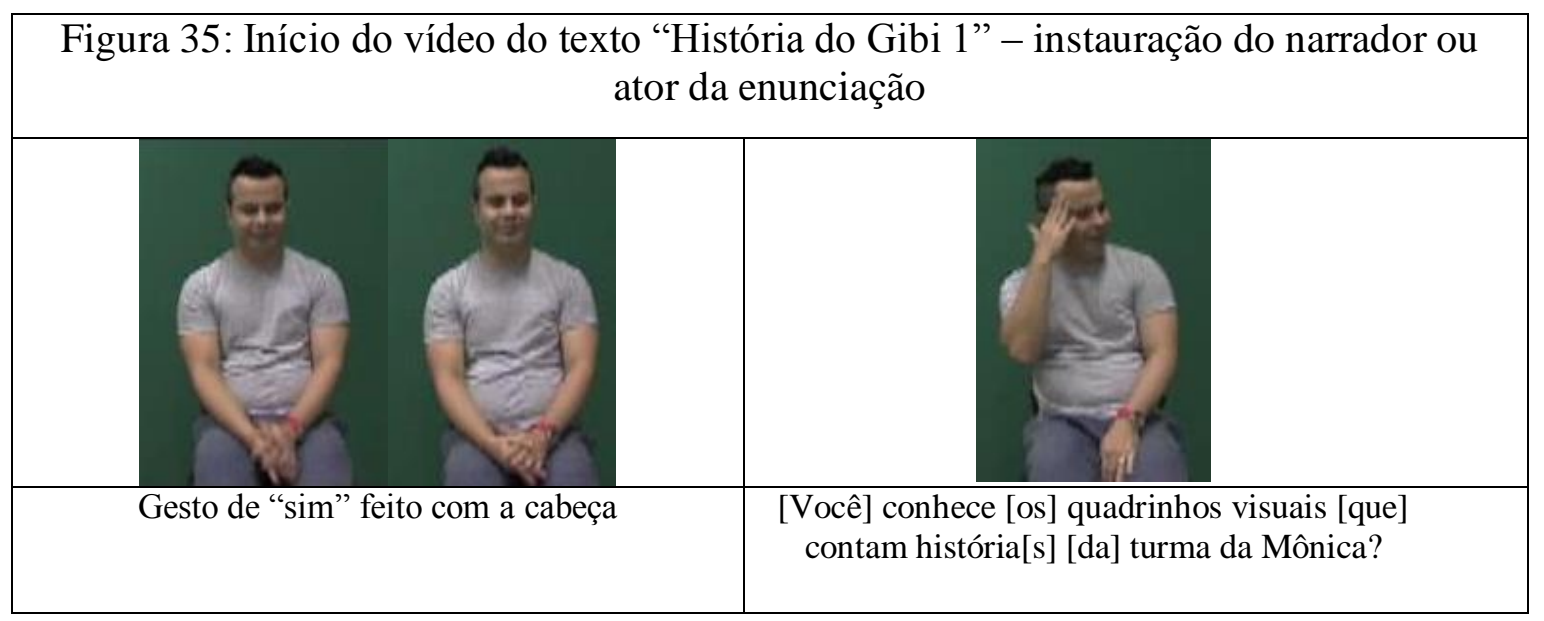

Quando Celso se vira para a esquerda e direciona seu tronco, cabeça e olhar para a sua frente, à esquerda, onde está seu narratário, e pergunta se ele conhece as histórias em quadrinhos da turma da Mônica, é instaurado o narrador do texto. Como foi dito, esse texto explicita esse momento da narração, uma vez que narrador e narratário interagem antes de a história propriamente dita ser contada. Há, nesse instante, a apresentação do que será narrado na sequência ${ }^{94}$.

$\mathrm{Na}$ figura 36, a seguir, podemos ver o momento em que esse narrador realiza um apontamento (um sinal que pode ser considerado um pronome usado em situações de formalidade) e instaura, assim, um narratário ${ }^{95}$. Esse apontamento, feito no final da pergunta,

\footnotetext{
${ }^{94} \mathrm{Como}$ todo enunciado produzido pressupõe a existência de um enunciador, não precisamos pensar mais em no "autor" e "leitor" de carne e osso envolvidos nessa interação. Os dois já sincretizam tanto o papel de enunciador e enunciatário, quanto de narrador e narratário e interlocutor e interlocutário, respectivamente.

${ }^{95}$ PRO é uma notação de Liddell (2003) para sinais pronominais que se referem a não primeira pessoa (segundas ou terceiras do discurso). Em geral, esse apontamento é feito com o dedo indicador em riste. O apontamento realizado pode ser, então, considerado uma variação do apontamento que em geral é feito para se referir à segunda ou terceira pessoas. A mão, nessa sinalização, está aberta, com todos os dedos apontados para frente. Na ASL, Liddell analisa esse tipo de apontamento como sendo formal e, por isso, pode receber a notação PRO-FORMAL (p.33-34).
} 
como uma forma de confirmar a informação de que o narratário conhece a história, mostra que ocorre uma debreagem enunciativa de pessoa (mais precisamente uma debreagem enunciativa da enunciação). Nesse instante, o narrador se projeta no enunciado como um $e u$, ao projetar seu narratário, como um tu/você.

Figura 36: Início do vídeo do texto "História do Gibi 1" - interação entre narrador e narratário

\begin{tabular}{|c|c|}
\hline CONHECER & PRO-FORMAL \\
\hline [Você] conhece [os] quadrinhos visuais [que] contam \\
história[s] [da] turma da Mônica?
\end{tabular}

Como foi dito, temos, na "História do Gibi 1", enunciados do narrador, no nível da narração, mostrado na figura 36, e enunciados do narrador, no nível do narrado. Esses, muitas vezes, não estão explicitados, mas estão sincretizados com as falas das personagens, quando ocorrem as debreagens de segundo grau no interior no texto.

No nível da narração, ainda é possível identificar mais momentos de interação explícita entre o narrador e o narratário do texto. Como no início do vídeo, o narrador olha para frente e interage com seu narratário, em outros dois momentos da história, para lhe fazer perguntas retóricas. O primeiro deles é quando, depois de dizer que o Cebolinha não gosta do que está vendo, volta-se para seu narratário e pergunta: “o que aconteceu?”, na figura 37.

\begin{tabular}{|c|c|c|}
\hline \multicolumn{4}{|c|}{ Figura 37: pergunta do narrador ao narratário } \\
\hline COMO & ACONTECER & \\
\hline
\end{tabular}


A outra situação em que isso acontece é quando o narrador pergunta se o narratário sabe como o coelhinho da Mônica se encontra, na figura 38.

\begin{tabular}{|l|l|}
\hline \multicolumn{3}{|c|}{ Figura 38: pergunta do narrador ao narratário } \\
\hline
\end{tabular}

Nesse momento da história, tanto o tronco quanto o olhar do narrador estão voltados para o narratário. Logo depois, o narrador desvia o olhar do narratário e continua sua contação, movendo o corpo de várias formas. Depois da primeira pergunta, ele conta o que chamou a atenção de Cebolinha, e, depois de dizer o nome do coelhinho, continua a contar o que o Cebolinha estava fazendo, descrevendo todo o cenário em se encontra a personagem.

O narrador do nível do narrado também já aparece explicitado nos enunciados iniciais do texto. Na figura 35, pudemos ver o corpo do sinalizador, quando faz o sinal de SIM com a cabeça e o instante em que, ao terminar de realizar esse gesto, assume uma posição mais ereta, na cadeira, e assume um papel de enunciador e de narrador do texto e começa a contar a história do Cebolinha. As marcas dessa passagem de uma instância enunciativa a outra é realizada pelo corpo: pelo movimento do tronco, da cabeça e mudança na direção do olhar. Ao longo da história, é possível perceber que os traços que caracterizam a passagem da instância das personagens para essa instância do narrador também são a direção do corpo, da cabeça e do olhar para o narratário ${ }^{96}$. Essas caraterísticas de narrador também são observadas em textos narrados em terceira pessoa ${ }^{97}$.

Para identificar, no narrado, o discurso citante, fala do narrador, e o discurso citado, fala das personagens, foram observados alguns aspectos visuais e gestuais presentes no texto. A ideia

\footnotetext{
${ }^{96}$ Nas línguas orais, também é possível marcar bem essa passagem do nível do narrador para o nível das personagens, por meio de diferenças na entonação, no timbre, no ritmo de fala e nos gestos faciais e corporais.

${ }^{97}$ McCleary \& Viotti (2010, 2011 e 2014) fazem uma descrição mais detalhada sobre a criação do narrador e a instauração dessa voz narrativa, no texto "História da Pera" (Pear Story), sinalizado pelo surdo Alexandre Melendez, que os autores vêm analisando em seus trabalhos.
} 
foi tentar mapear os momentos em que essas transições entre uma instância enunciativa (a do narrador) e outra (a dos interlocutores) eram mais evidentes e como cada uma delas se mantinha caracterizada no discurso $^{98}$. $\mathrm{Na}$ figura 39, é possível notar que, primeiramente, o olhar do sinalizador se dirige para frente e a direção do tronco está voltada para o narratário. Nesse caso, o narrador parece estar explicitado no texto. Em outros, no entanto, na sequência, é possível observar que há uma mudança na expressão facial e ocorrem certos movimentos do corpo, que “escondem” esse narrador e já parece caracterizar a personagem e demonstrar a sua ação 99 .

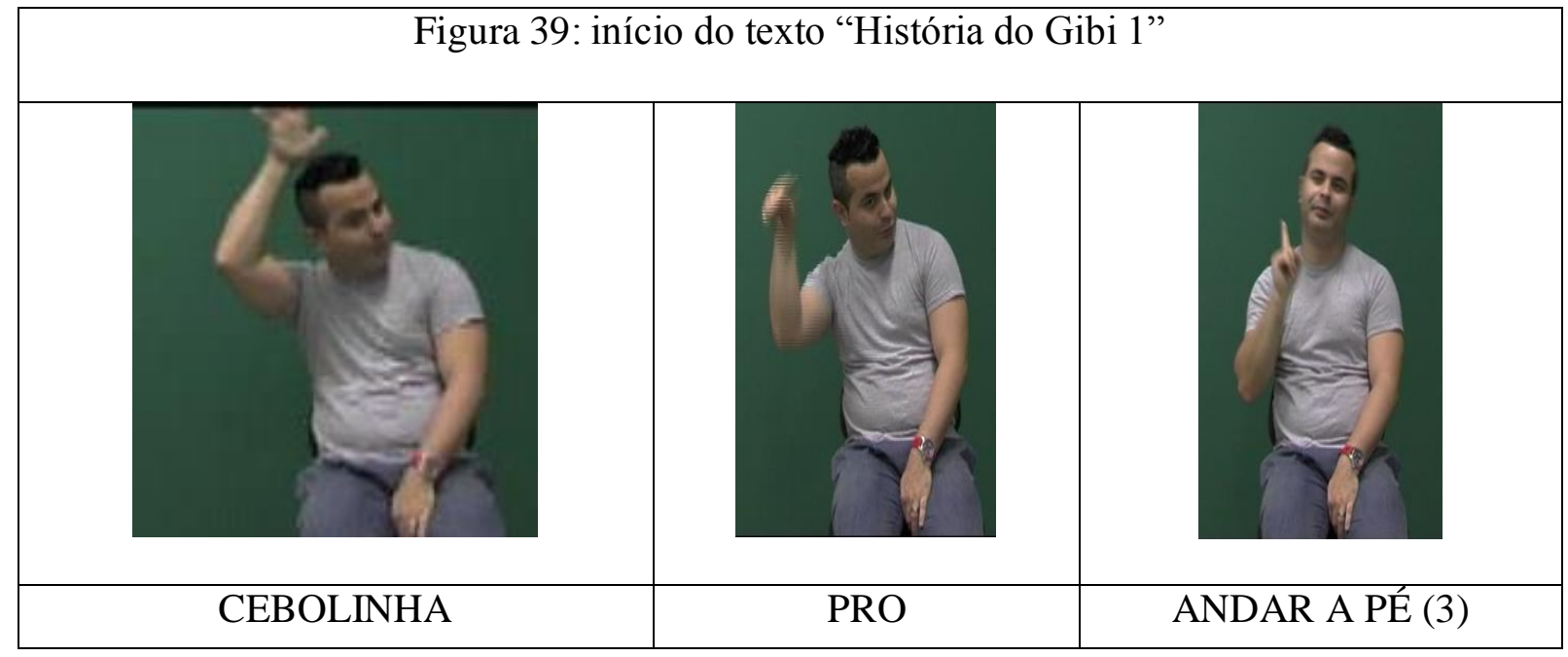

Com base no que Liddell (2003) descreveu na ASL, podemos dizer que a fala do narrador, no nível do narrado, apresenta-se, então, de forma geral, de três maneiras no texto: (i) quando há apresentação ou retomada de alguma personagem (o sinalizador faz o sinal que corresponde ao nome da personagem); (ii) quando o narrador descreve o cenário da ação (o sinalizador se utiliza do espaço de sinalização que está na sua frente e cria pontos nesse espaço, indicando, por meio de sinais manuais, o que cada lugar representa na imagem que está criando); (iii) quando o narrador interpreta a ação da personagem e, ao mesmo tempo, narra a história do Cebolinha (o sinalizador

${ }^{98}$ É preciso dizer que em muitos momentos, enquanto conta um evento, o narrador olha para seu narratário, ou seja, durante um discurso citado, muitas vezes, fica explícito o discurso citante nos textos sinalizados.

${ }^{99}$ Seguindo as ideias de Clark \& Gerrig (1990) e Clark (1996) sobre as interações face a face das línguas orais, Silva (2014: 03) descreve, em seu estudo, demonstrações das ações como sendo uma estratégia cognitiva que envolve mais dois aspectos relacionados à construção do discurso: a descrição (uso de itens linguísticos mais convencionais) e a indicação (uso de apontamentos, direção do olhar, movimentos do corpo, etc.). Para o autor, a demonstração "consiste em usar elementos do espaço de enunciação", como "o corpo do sinalizador, o espaço em volta dele, objetos físicos presentes" nesse espaço "ou, até mesmo, elementos mais abstratos, como a progressão temporal, dentre outros", para "apresentar iconicamente aspectos sensorialmente perceptíveis (em geral, visuais e sonoros) de um referente (entidades, estados, processos e ações)". Para um estudo mais aprofundado sobre esse assunto, ver Silva (2014). 
realiza sinais manuais, posicionando-se da forma como representou as personagens, e gesticula, demonstra com seu corpo o que aconteceu).

Segue, abaixo, uma descrição breve de cada uma dessas maneiras de o narrador se apresentar e fazer sua manutenção no texto "História do Gibi 1":

(i) quando há apresentação ou retomada de alguma personagem ${ }^{100}$

$\mathrm{Na}$ figura 40, abaixo, vemos diferentes falas do narrador, quando apresenta as personagens da história: Cebolinha, Magali, Cascão e Marina. Uma evidência de que, nesses trechos, os enunciados são do narrador pode ser encontrada na posição do olhar e do tronco dele direcionado para o narratário. Como já foi dito, Celso Badin contou essa história para um intérprete, que não aparece no vídeo, mas que estava sentado à frente e à esquerda do sinalizador, no momento da narração.

\begin{tabular}{|c|c|c|c|}
\hline \multicolumn{3}{|c|}{ Figura 40: Enunciados do Narrador - Apresentação das personagens } \\
\hline CEBOLINHA & MAGALI & CASCÃO & MARINA \\
\hline
\end{tabular}

(ii) quando o narrador descreve o cenário da ação

Na figura 41, podemos ver que o narrador apresenta objetos ou seres que estão em uma das cenas da história, olhando também para seu narratário e deslocando suas mãos pelo espaço de

\footnotetext{
${ }^{100}$ Para um estudo mais aprofundado sobre referenciação de personagens em textos em libras, ver o estudo de Bolgueroni (2013) e Bolgueroni \& Viotti (2013).
} 
sinalização, ora realizando sinais manuais, ora criando os pontos no espaço para esses objetos ou seres. Silva (2014) trata esse tipo de sinalização como um tipo de demonstração ${ }^{101}$.

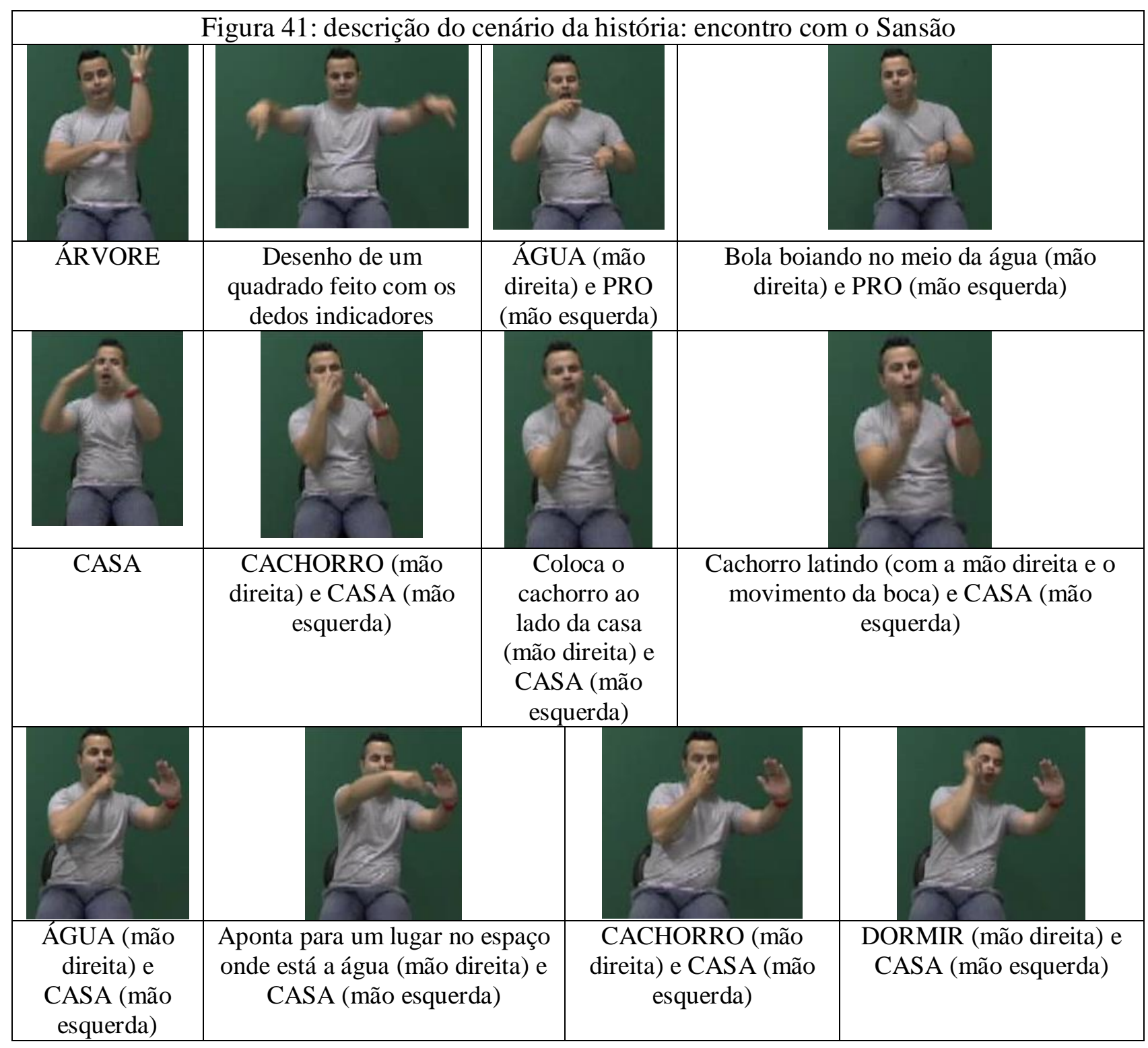

\footnotetext{
${ }^{101}$ Silva (2014: 77) mostra que uma das pistas para o reconhecimento da construção de um cenário no espaço, nos discursos sinalizados, é o posicionamento das mãos, sua orientação e a direção do olhar do sinalizado. Em geral, o olhar acompanha as mãos, e desvia mais do narratário; os movimentos dos sinais ficam mais largos; alguns sinais ganham outro aspecto ao serem realizados, criando-se, assim, também a perspectiva a partir da qual todo o cenário é construído no espaço de sinalização. Segundo McCleary \& Viotti (2010, 2011 e 2014), as demonstrações têm um papel central na organização dos textos sinalizados.
} 
(iii) quando o narrador interpreta a ação da personagem e, ao mesmo tempo, narra a história

Como foi dito, a "História do Gibi 1" está repleta de momentos em que há um sincretismo de narração e ação. O sinalizador, muitas vezes, parece acumular duas importantes funções: a de narrar os acontecimentos (usando itens lexicais) e demonstrar (sinais e gestos corporais, mímicas e pantomimas) como a ação de uma personagem foi de fato realizada (uma espécie de interpretação da cena da história original, uma imitação da imagem, que não deixa de ser uma narração dos fatos) e, para isso, em muitos trechos parte seu corpo, para expressar essas duas vozes narrativas $^{102}$.

$\mathrm{Na}$ figura 42, abaixo, destacamos seis momentos em que a fala do narrador se combina com as próprias atitudes das personagens que participam da cena. O que se pode observar é que, em geral, enquanto as mãos cumprem o papel de narrador, que conta a história; o olhar, as expressões faciais e a posição do tronco no espaço também parecem ser uma demonstração dos gestos e ações da personagem ${ }^{103}$.

\begin{tabular}{|c|c|c|}
\hline \multicolumn{3}{|c|}{ Figura 42: narração e ação da personagem } \\
\hline PESSOA[escalando] (mão direita) e & ENTREGAR [maçã] & COMER \\
ÁRVORE (mão esquerda) & & \\
\hline \\
\hline PESSOA [pular] (mão direita) e pedra (mão & Cebolinha se & Cebolinha no galho da \\
esquerda) & afogando & árvore \\
\hline
\end{tabular}

\footnotetext{
${ }^{102}$ Para um estudo mais aprofundado sobre a partição do corpo e vozes narrativas, em textos em libras, ver os estudos de Liddell (2003), Dudis (2004, 2007 e 2011), McCleary \& Viotti (2010, 2011 e 2014), Silva (2014), etc.

${ }^{103}$ Tarcísio de Arantes Leite (UFSC) comentou que não dá para saber com tanta precisão que partes do corpo estão relacionadas ao narrador ou às personagens de um texto, como também tentou fazer Silva (2014) em seus exemplos.
} 
Na figura 42, acima, podemos ver, nas expressões faciais do sinalizador, a representação da personagem Cebolinha, que sobe na árvore, entrega a maçã à Magali, pula as pedras para pegar a bola para o Cascão, quase se afoga, e quase cai de um galho. Ao mesmo tempo em que o sinalizador realiza alguns sinais, como o de subir, entregar, comer, pular, o rosto dele e os movimentos feitos pelo tronco, no momento dessas sinalizações, demonstram o estado dessas personagens ao realizar essas ações. O sinalizador também pode apenas demonstrar algumas dessas ações, como no caso de o Cebolinha se afogando, ou de ele pendurado em um galho de uma árvore. Nesses dois casos, fica claro o que está acontecendo porque, apesar de não haver um item lexical da língua, conseguimos entender a situação que está sendo narrada por meio de toda a gestualidade de quem sinaliza ${ }^{104}$.

A fala dos interlocutores do nível do narrado também é caracterizada por diferenças na expressão facial, direção do corpo e olhar do sinalizador. O discurso citado ocorre quando há simulações de diálogos, como a da figura 43, ou seja, quando temos uma das debreagens de segundo grau da "História do Gibi 1", apresentadas com mais detalhes no próximo capítulo.

\begin{tabular}{|c|c|}
\hline \multicolumn{2}{|c|}{ Figura 43: diálogo entre o Cebolinha e a Magali } \\
\hline Cebolinha & Magali \\
\hline AJUDAR & PRO-1 $^{105}$ (mão direita) e ÁRVORE (mão esquerda) \\
\hline
\end{tabular}

Todos esses detalhes descritos nesta seção que caracterizam tanto aspectos do nível da narração quanto características do nível do narrado, como as falas do narrador e as falas das personagens e as transições entre elas puderam ser identificados por meio do trabalho de transcrição da "História do Gibi 1".

\footnotetext{
${ }^{104}$ Esse sincretismo entre narrador e personagem, e entre a narração e o que é narrado, também se verifica o tempo todo nas línguas orais, tanto nas conversações cotidianas como em contações de histórias. Nas línguas orais, essa figurativização das personagens e das ações das personagens, por exemplo, aparecem nos gestos que acompanham a fala ou na mudança de prosódia (ou nos dois).

${ }^{105}$ Pode-se fazer a notação PRO-1 para o sinal para EU, seguindo o modelo de descrição de Liddell (2003).
} 
Uma segmentação muito parecida a essa também pode ser verificada, como já foi dito, no texto "Metáfora - O escorpião e a tartaruga". É possível descrever, no texto de Rimar, o nível da narração, quando o narrador diz que vai falar sobre a metáfora do escorpião e da tartaruga, e os três níveis do narrado: (i) a primeira história que ele conta sobre seu pai e sua irmã ouvinte; (ii) a segunda história que acontece com sua irmã e um homem do trabalho dela, e (iii) a fábula propriamente dita, que é a história do escorpião e da tartaruga, que foi contada por esse homem à irmã de Rimar. A fábula é usada pelo narrador, no final do texto, para ilustrar e terminar sua explicação do início do vídeo.

É possível, por meio de marcas explícitas, observar cada um desses momentos do texto de Rimar. Na figura 44, há a apresentação do tema do texto e o título da história que será narrada. Em seguida, nas figuras 45, 46 e 47, podemos perceber a introdução de cada uma das três partes que compõem o nível do narrado.

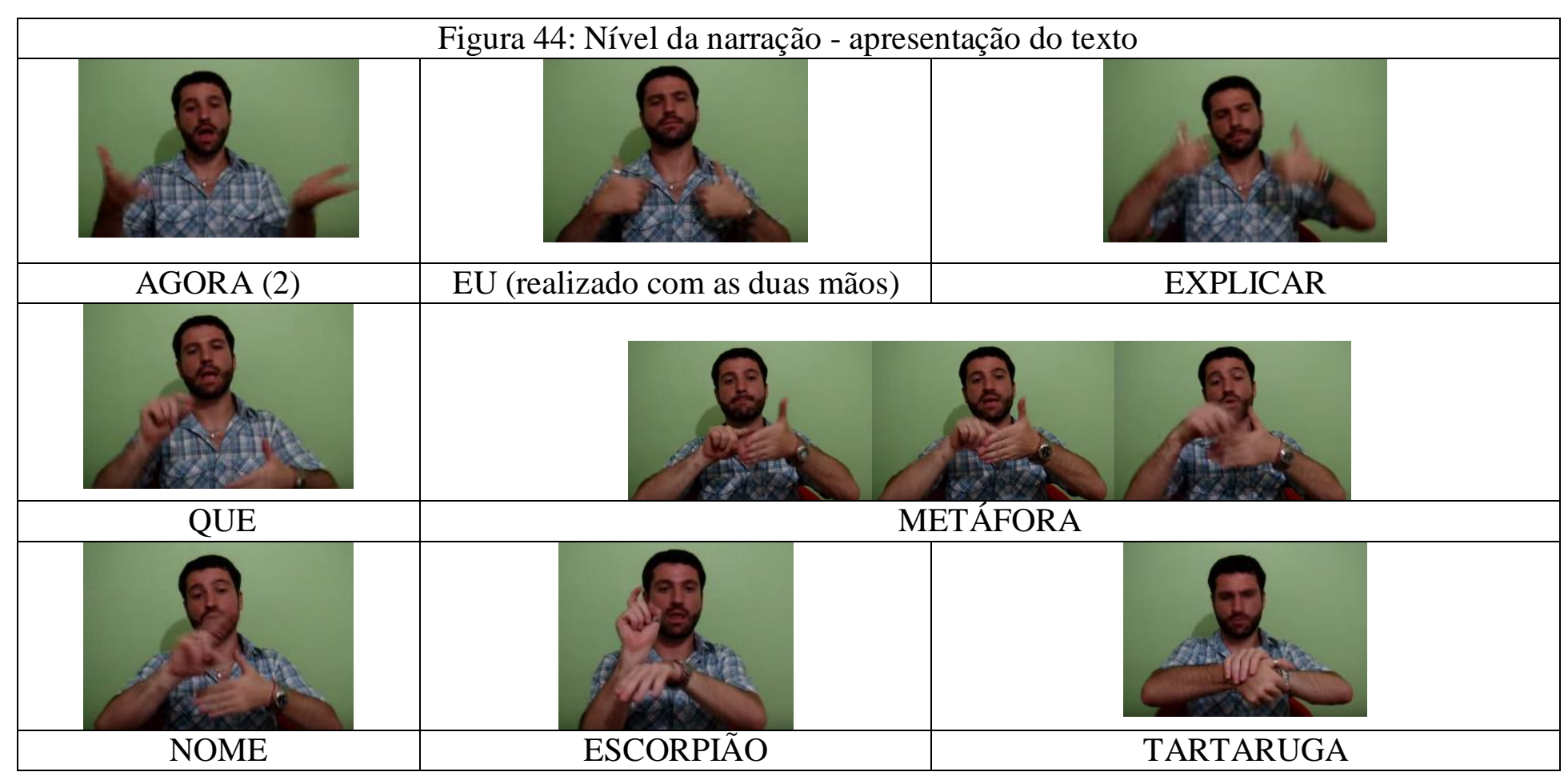




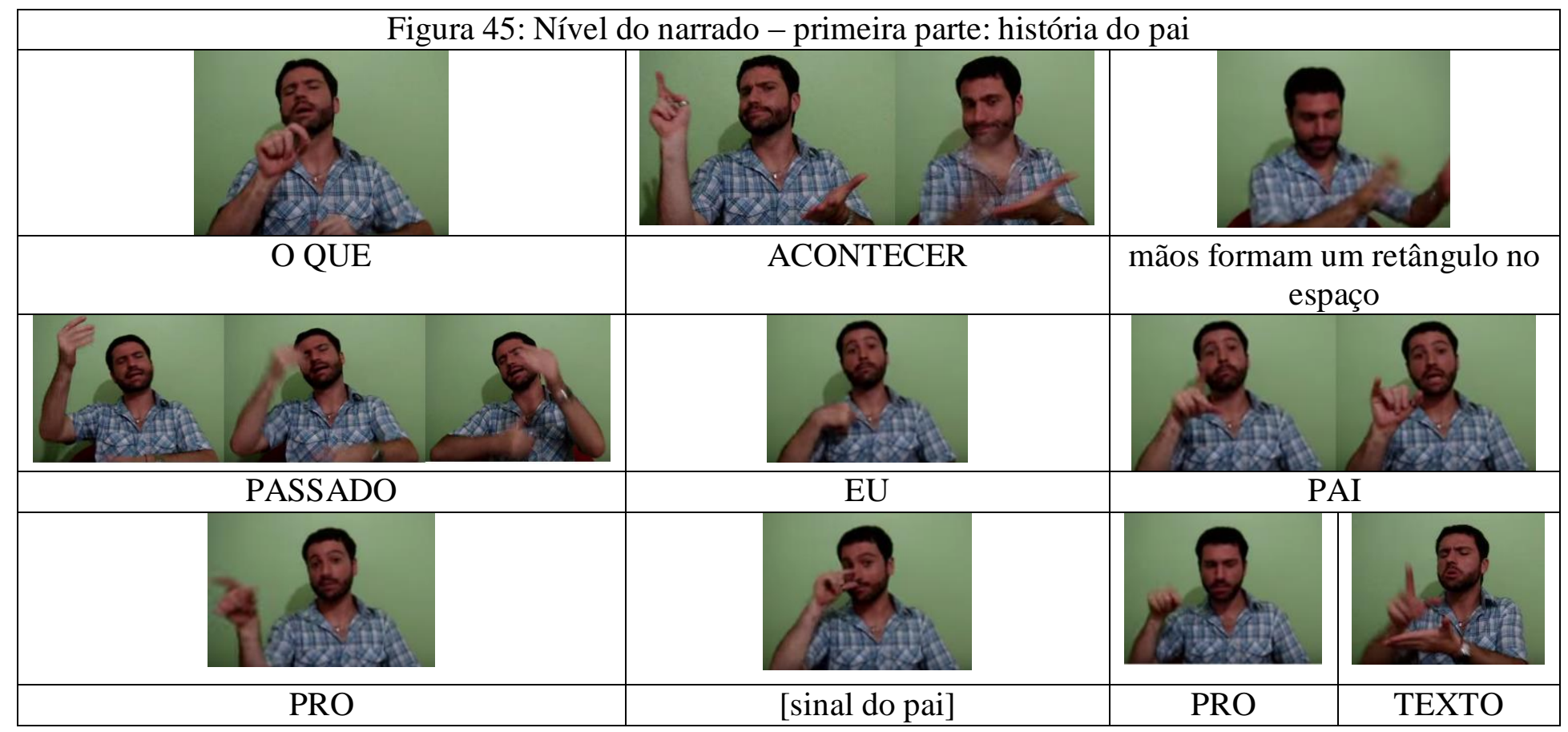
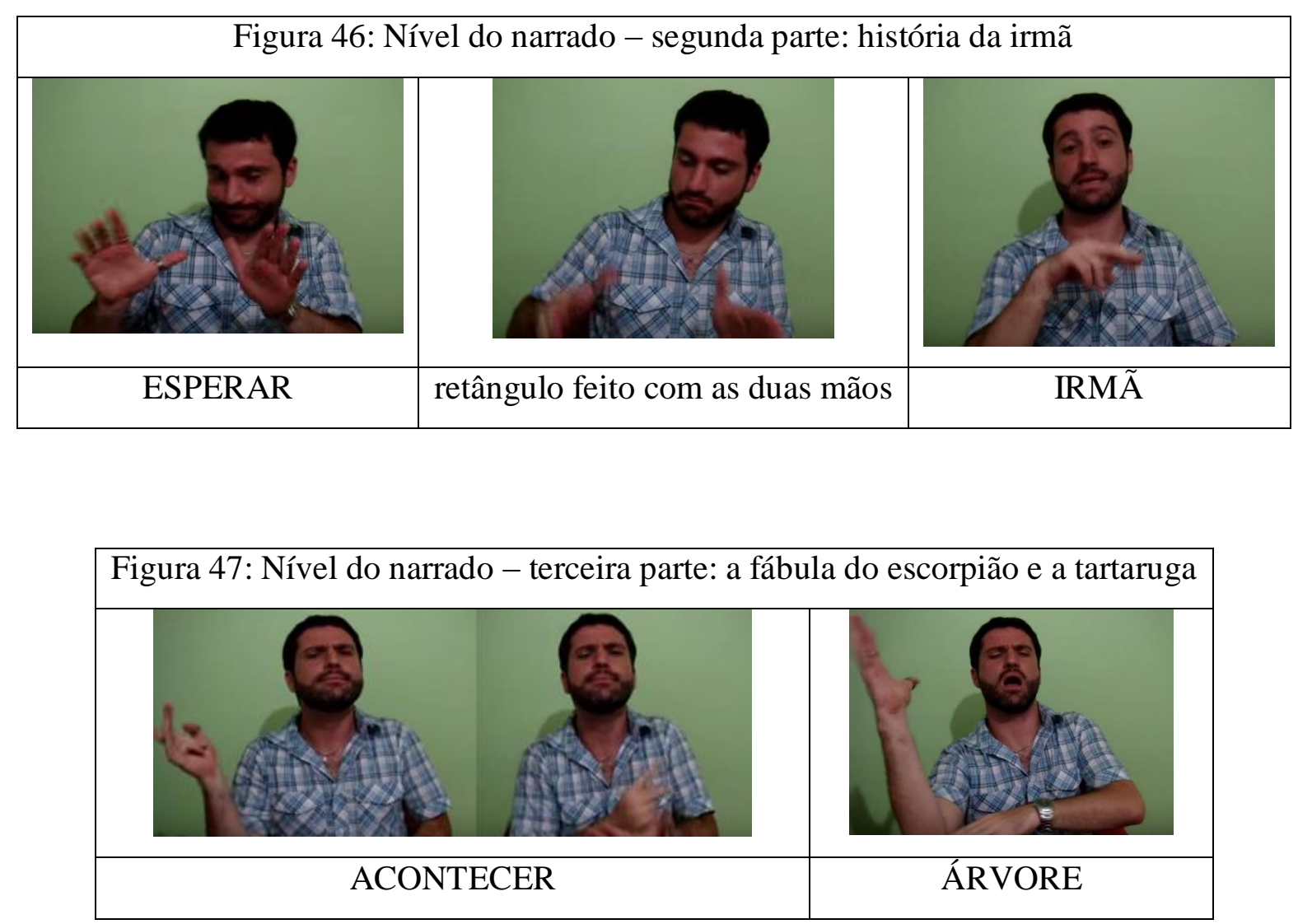

Também há demonstrações no texto de Rimar, tanto das personagens quanto das ações delas, assim como a simulação dos discursos diretos, da filha com o pai, da irmã e Rimar com o 
homem, e do escorpião com a tartaruga, como é possível observar, respectivamente, nas figuras 48,49 e 50.

\begin{tabular}{|c|c|}
\hline \multicolumn{3}{|c|}{ Figura 48: Interação entre o pai e a filha } \\
\hline O pai & A filha \\
\hline PERGUNTAR & EXPLICAR \\
\hline
\end{tabular}

\begin{tabular}{|c|c|}
\hline \multicolumn{2}{|c|}{ Figura 49: Interação entre a irmã de Rimar e o homem } \\
\hline A irmã de Rimar & O homem \\
\hline & \\
\hline & \\
\hline PERGUNTAR & \\
\hline & \\
\hline [a irmã de Rimar se vira para o homem e \\
pergunta o que ele quer]
\end{tabular}

\begin{tabular}{|c|c|c|c|}
\hline \multicolumn{4}{|c|}{ Figura 50: Diálogo entre a tartaruga e o escorpião } \\
\hline \multicolumn{2}{|c|}{ A tartaruga } & \multicolumn{2}{c|}{ O escorpião } \\
\hline
\end{tabular}


Toda essa segmentação realizada tanto no texto "História do Gibi 1" como no texto "Metáfora - O escorpião e a tartaruga" constitui o primeiro passo metodológico para a análise do tempo em libras que será apresentada a seguir.

\section{4) Considerações finais do capítulo}

Neste capítulo, apresentamos o caminho metodológico percorrido na pesquisa: (i) o levantamento de dados do dicionário e a construção de um corpus formado por seis textos, contados por usuários fluentes em libras - "História do Gibi 1", "História do Gibi 2", "O amor é surdo", "Minha Vida", "Sonhos" e "Metáfora - O escorpião e a tartaruga"; (ii) a transcrição desses dados, no ELAN, com base nos trabalhos de McCleary \& Viotti (2007) e McCleary, Viotti \& Leite (2010), para descrever detalhes do plano de expressão dos discursos da língua, e (iii) uma proposta de segmentação do texto "História do Gibi 1" e "Metáfora - O escorpião e a tartaruga" em dois níveis enunciativos que as compõem e que são pertinentes para a descrição e análise do tempo que será apresentada a seguir. 


\title{
Capítulo 4
}

\section{O tempo em textos em libras}

\author{
"No entanto eu levanto uma hora mais cedo \\ e me mando pra busca do tempo perdido \\ evidente que eu tento de tudo que é jeito \\ mas não acho meu tempo, está sempre escondido."
}

Tempo escondido Luiz Tatit

Neste capítulo, o objetivo é apresentar uma proposta, no âmbito da semiótica greimasiana, de descrição e análise dos tempos que aparecem nos textos que formam o corpus desta pesquisa, para responder às questões levantadas na introdução desta tese. O foco da análise está no nível discursivo do texto, mais especificamente no estudo da sintaxe desse nível do percurso gerativo de sentido. A ideia é descrever como são construídos e organizados, nos discursos em libras, os sistemas temporais enunciativos e enuncivos de cada uma das histórias selecionadas para este estudo. Neste capítulo, ainda, são mostrados os efeitos de sentido gerados pela instauração de tempo em alguns dos textos analisados. Ao final, é apresentada uma síntese com os resultados que foram obtidos com este trabalho.

4.1) Descrição e análise do tempo nos textos em libras

Como já foi dito, o objetivo desta tese é descrever e analisar a organização do tempo em libras. O estudo da temporalização compreende tanto a localização quanto a programação temporal. Esta tese se dedicou à verificação das maneiras que essa língua dispõe para localizar o tempo em seus discursos. Como foi mostrado, as línguas de sinais contam com mecanismos de enunciação gerais, que são responsáveis pela instauração da pessoa, do espaço e do tempo e pela criação de diferentes efeitos de sentido em seus discursos. Os estudos sobre algumas línguas de sinais do mundo vêm mostrando que a manifestação desses mecanismos discursivos é, como em qualquer outra língua natural, própria de sua modalidade, no caso, visual-gestual.

De um modo geral, algumas pesquisas são contra a ideia de que existam morfemas flexionais de tempo nos verbos das línguas de sinais, embora outros autores defendam, por 
exemplo, a ideia de que há morfemas flexionais, como de pessoa em verbos indicadores (ver Felipe de Souza, 1998) ou morfemas flexionais de aspecto associado a tempo (ver Finau, 2004). Neste trabalho, não temos a preocupação de entrar nesse debate. $\mathrm{O}$ importante, para a descrição que é apresentada a seguir, é o que a maior parte de todos esses estudos vem mostrando que é o fato de, como outras línguas, as línguas sinalizadas contarem com um léxico de tempo composto por sinais que têm a função de indicar tempo. Esses itens lexicais são os advérbios ou as expressões adverbiais, convencionais, que manifestam a categoria de tempo nessas línguas.

Na figura 51, abaixo, é possível ver alguns dos sinais mais produtivos na língua, usados na marcação temporal em diferentes textos, inclusive nos analisados nesta pesquisa.

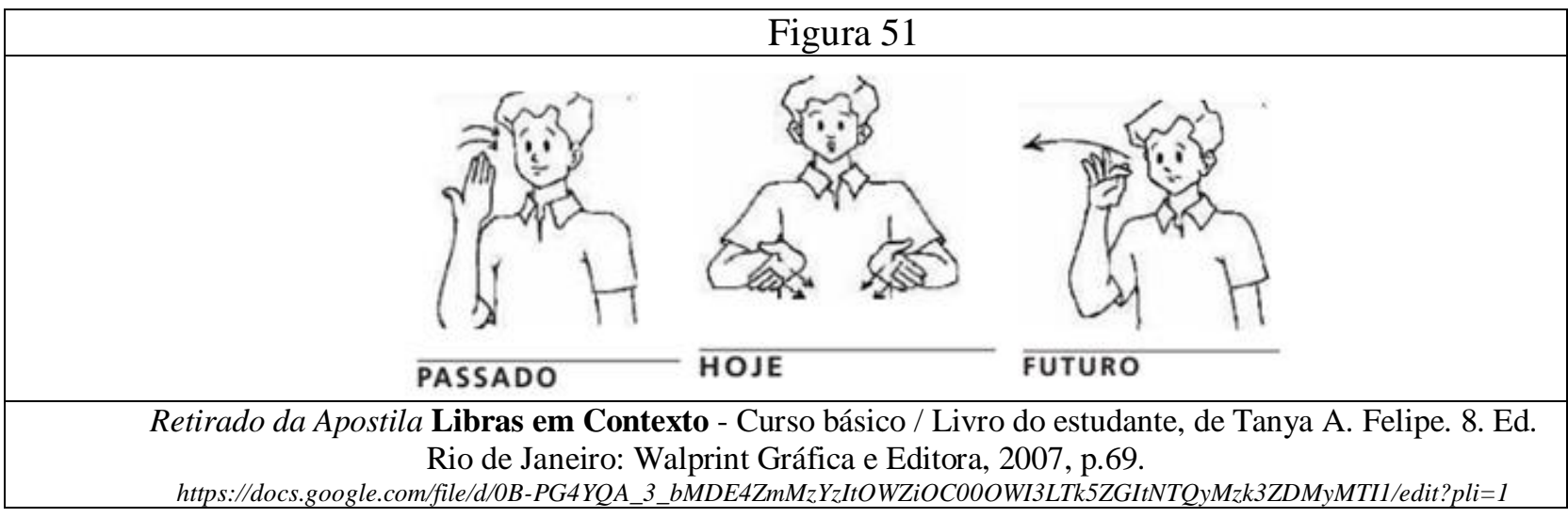

Muitos estudos sobre variadas línguas de sinais também têm mostrado, no entanto, que há outras formas, além dos itens lexicais dicionarizados, basicamente sinais feitos com as mãos, para expressar o tempo linguístico nos textos sinalizados. Trabalhos como os de Sinte (2013), Alkoby (s/d), Johnston \& Schembri (2007) e Finau (2004), já comentados anteriormente nesta tese, apontam como sendo marcadores temporais outros gestos corporais, como a direção do olhar, o movimento do tronco e da cabeça e a localização das mãos no espaço de sinalização, seguindo uma linha de tempo imaginária, que pode se situar na diagonal, perpendicularmente ou em frente ao corpo do sinalizador.

Como foi mostrado, no capítulo 2, tanto o movimento do tronco para frente e para trás, considerado pela literatura, como um marcador específico de tempo, como construção dessa linha temporal no espaço são variáveis e nem sempre ocorrem da mesma maneira e pelos mesmos motivos. O corpo do sinalizador se move, no espaço de sinalização, por várias razões discursivas, entre elas, para marcar pessoa (demonstrar personagens e as ações delas, criar discursos diretos) e para construir diferentes espaços (descrever o cenário de uma história, etc). A hipótese que este 
trabalho levanta, portanto, é que essas marcas das categorias da enunciação, tanto no nível enuncivo quanto no nível enunciativo, estão envolvidas com a instauração do tempo nos textos, mas não são marcadores específicos dessa categoria. A ideia que esta tese defende é a de que, nos textos em que não há marcas temporais explícitas e a literatura trata como tendo "tempo indefinido", pode-se considerar que o tempo foi construído a partir das categorias de pessoa e espaço, por meio de uma embreagem heterocategórica. Além disso, a linha de tempo pode ser construída de formas diferentes, conforme o tipo de discurso e a espacialização criada, como também foi mostrado no capítulo 2. Essa variação na forma de estruturar espacialmente o tempo nos leva à ideia de que não parece ser possível considerar que as formas que as línguas de sinais apresentam como marcadores temporais sejam morfemas fixos ou lexemas (unidades de conteúdo), o que não impede que eles possam ser entendidos como classemas, que, nos termos de Greimas (1973: 71), é um conjunto de semas contextuais, uma unidade do discurso superior ao lexema. Desse modo, o tempo pode, em libras, tanto ser marcado por meio do léxico quanto de forma classemática, por elementos diversos que instauram as categorias enunciativas de um modo geral, conforme o contexto discursivo.

Como qualquer outra língua, as línguas de sinais apresentam formas, próprias de sua modalidade, para expressar os mecanismos discursivos e construir as temporalidades de seus discursos (o procedimento da temporalização, que envolve a localização temporal, a programação temporal e a aspectualização). Embora haja especificidades no modo de manifestar as categorias de pessoa, de espaço e de tempo, as línguas sinalizadas também contam com debreagens e embreagens, que também geram efeitos de proximidade ou distanciamento da enunciação, ilusões enunciativas ou referenciais. Uma diferença são as marcas de expressão, pois essas línguas contam com um plano de expressão visual, gestual, e carrega, assim, suas particularidades, como as mais variadas linguagens, que contam com um canal de produção e significantes visuais, gestuais, plásticos, etc.

As línguas de sinais também contam com procedimentos de programar seus discursos temporalmente por meio da sucessão, simultaneização e a inversão dos fatos narrados. Embora o interesse desta tese recaia sobre o estudo da localização do tempo nos textos, é possível apontar alguns aspectos sobre a programação temporal, que pode ser objetivo de trabalhos futuros. No corpus analisado nesta pesquisa, foi possível levantar alguns sinais ou formas de sinalização que podem ser considerados sequenciadores em libras, por exemplo. Na figura 52, a seguir, é possível ver a realização de um advérbio que pode fazer o encadeamento dos fatos em um texto. Trata-se 
do sinal DEPOIS, realizado por Regiane, no texto "Sonho com um carro novo", quando uma personagem pergunta a outra no que ela trabalhará daqui cinco anos (ou depois de cinco anos).

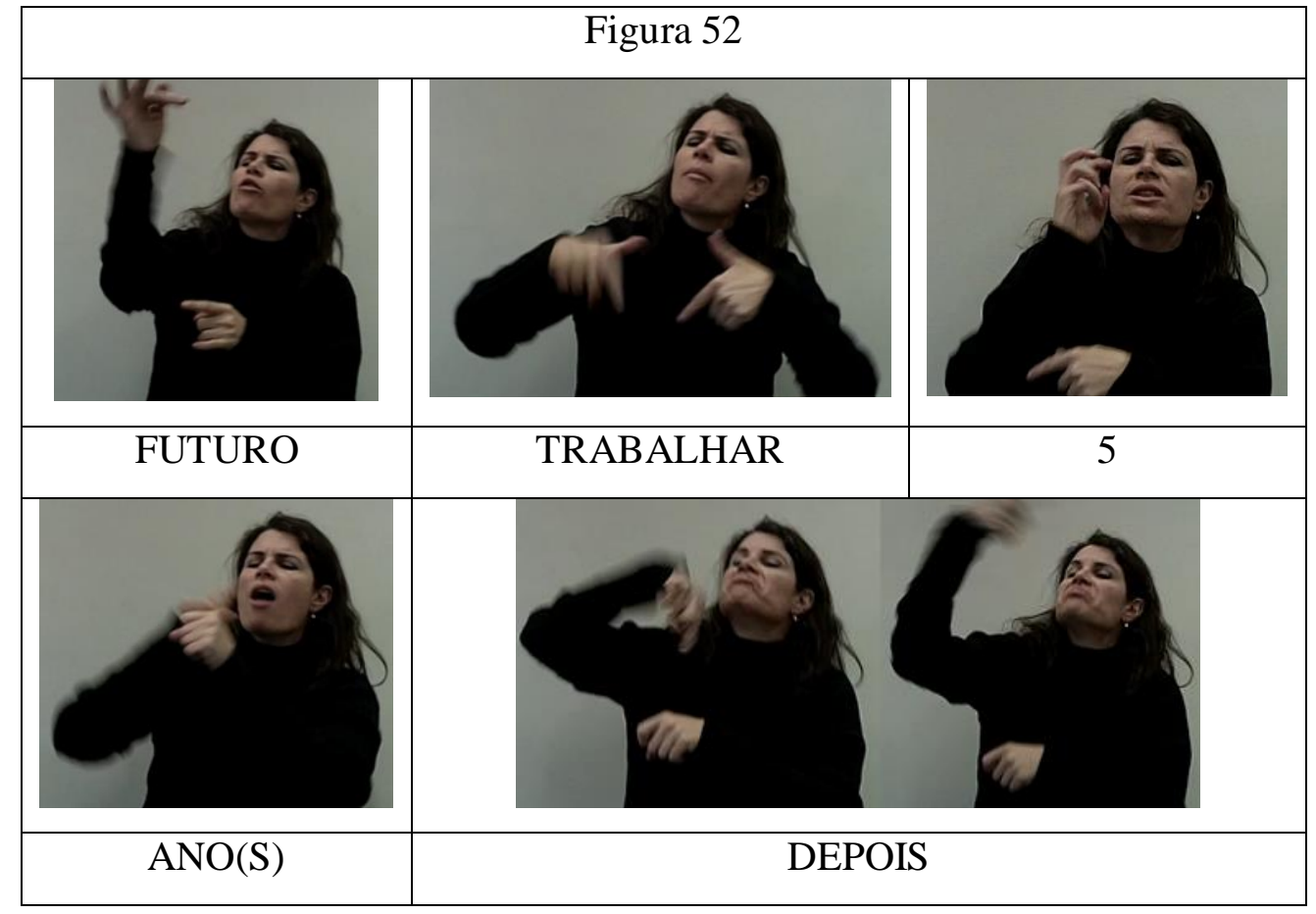

O uso do sinal DEPOIS, além de marcar que o evento narrado não é concomitante ao momento de referência do texto, posterior a ele (futuro), também organiza os fatos que estão sendo contados, dando uma ordem à narrativa.

Outro exemplo do uso de um sequenciador pode ser observado no início do texto "Metáfora - O escorpião e a tartaruga", quando Rimar cria um espaço entre as mãos para indicar um período temporal e, ao deslocá-lo para a esquerda, primeiramente, na figura 53, e depois para a direita, juntamente com o gesto de ESPERAR, na figura 54, ordena os fatos narrados, e encadeia os acontecimentos.

\begin{tabular}{|c|c|c|}
\hline \multicolumn{3}{|c|}{ igura 53: Nível do narrado - primeira parte: história do pai } \\
\hline O QUE & ACONTECER & mãos formam um retângulo no espaço \\
\hline
\end{tabular}




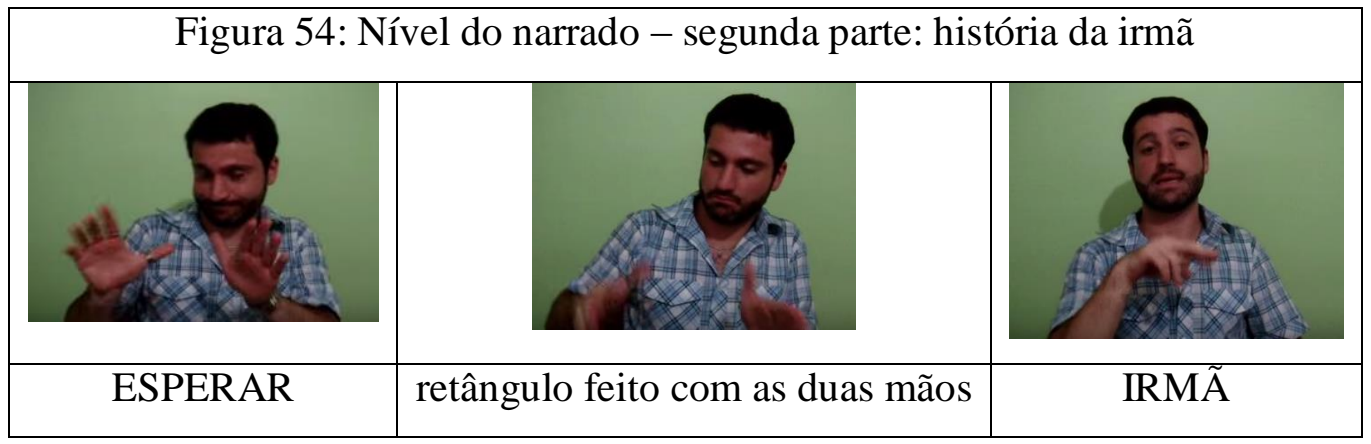

A programação temporal dos textos sinalizados apresenta muitas particularidades. Uma vez que essas línguas contam com o espaço para construir seus enunciados, há recursos visuais e espaciais empregados para fazer o encadeamento dos fatos, criar sucessões, inversões e eventos simultâneos, explorando a movimentação do corpo, a multiplicidade de articuladores. A programação temporal dos textos em libras, portanto, parece ser bem característica de seu plano de expressão, permitindo marcar eventos concomitantes, visual e simultaneamente, no espaço ${ }^{106}$.

Como foi dito, esta pesquisa se concentrou na investigação dos procedimentos de localização temporal. A descrição e a análise do tempo proposta nesta pesquisa foram realizadas a partir do estudo de textos em libras que compõem o corpus deste trabalho. A ideia foi verificar qual o tempo em uso nos discursos e como ele é instaurado, por meio de debreagens e embreagens, para situar os estados ou acontecimentos narrados na linha de tempo, a partir de um marco referencial (MR) presente, pretérito ou futuro, e construir, assim, no interior desses textos, sistemas temporais enunciativos e sistemas temporais enuncivos, com diferentes efeitos de sentido, como qualquer outra língua.

Retomamos aqui as quatro questões levantadas na introdução deste trabalho e que conduzirão todo o estudo descritivo e analítico que será apresentado neste capítulo.

1. Como é que uma língua de sinais estrutura formalmente suas relações temporais? Quais são as estratégias gramaticais e discursivas usadas para marcar e organizar o tempo nos textos em libras?

\footnotetext{
${ }^{106} \mathrm{Um}$ dado interessante sobre libras foi mencionado por João Paulo da Silva, colega de grupo de pesquisa. No texto que analisa em sua dissertação de mestrado, aparece um caso de simultaneização temporal muito próxima ao que ocorre em textos fílmicos, por exemplo. O narrador está descrevendo uma situação de tensão entre dois jogadores numa competição de pingue-pongue, e, por uns instantes, muda a cena que descreve, mostrando como estava a plateia. A simulação feita é de que uma ação é concomitante a outra: enquanto os jogadores estavam jogando, a plateia olhava o jogo. Para mais detalhes, ver Silva (2014). Essa forma de marcar a simultaneidade também aparece nos textos analisados nesta tese.
} 
2. Como são as debreagens temporais de um texto em libras?

2.1. Como se estabelece o sistema enunciativo e o sistema enuncivo de tempo em um texto em libras?

2.1.1. Como são instaurados os Momentos de Referência nos textos?

2.2. Como são estabelecidas as relações temporais internas nos enunciados em libras?

2.2.1. Como são instaurados os Momentos dos Acontecimentos?

2.2.2. Como se estabelece a relação de anterioridade, posterioridade e simultaneidade dentro dos discursos?

2.2.3. Como se estabelece a relação de concomitância ou não dos acontecimentos narrados com o Momento de Referência que foi estabelecido no início do texto?

2.2.4. Quando não há qualquer item lexical que indique tempo realizado numa sinalização, como se sabe, nessa língua, se o evento descrito (seja ele da instância do narrador seja ele da instância dos interlocutores, nas debreagens internas) é narrado no presente, no passado ou no futuro?

3. Como são as embreagens temporais em libras?

3.1. Como se sabe quando um tempo é usado com valor de outro em um texto em libras?

3.2. Quais os tipos de embreagens temporais predominantes nos textos em libras?

4. Quais são os efeitos de sentido criados pelos mecanismos de instauração de tempo nos textos em libras?

Esta tese parte da ideia de que a maneira de marcar o tempo nas línguas de sinais pode ser altamente variável e depender de cada contexto de enunciação. Isso não quer dizer que não haja uma sistematização. A proposta de que o tempo, em libras, pode ser instaurado por um conjunto de elementos presentes na sinalização, como o movimento do corpo (tronco e cabeça), localização das mãos no espaço e a direção do olhar do sinalizador, que indicam, nos textos, as pessoas e o espaço discursivos. Isso mostra que há um tipo de sistematização do tempo nessas línguas. Todos esses marcadores discursivos não são específicos de tempo, mas, juntos ou combinados de alguma forma, podem criar as relações temporais no interior dos textos, por meio de uma neutralização dessas categorias enunciativas (de pessoa, de espaço e de tempo), ou seja, por meio de uma embreagem heterocategórica. Nesse sentido, a ausência de itens lexicais de 
tempo ou de uma marca mais explícita para isso não faz com que a marcação temporal seja imprecisa, nula, como a literatura sobre o assunto tem sugerido.

Cada um dos textos selecionados foi analisado segundo o aparato metodológico da semiótica greimasiana, e, nesta seção, são apresentados os resultados a que chegamos sobre a sintaxe discursiva deles, no plano do conteúdo, portanto, sobre a forma como cada um construiu suas relações temporais. Para este estudo, foram dados os seguintes passos, conforme já proposto no capítulo 3, da metodologia:

1) Segmentação das histórias analisadas em nível da narração e nível do narrado, quando isso foi necessário;

2) Identificação do ponto de referência (MR) que foi instaurado no texto (verificação das marcas de tempo que mostram que o texto é enunciativo ou enuncivo), nos dois níveis (da narração e do narrado);

3) Identificação dos tipos de debreagem de tempo ocorridos ao longo do texto e levantamento das marcas dos diferentes tempos que aparecem no decorrer da história (descrição do MA);

4) Verificação da ocorrência de embreagens no decorrer dos textos estudados.

A seguir, são apresentados os diferentes tempos, enunciativos e enuncivos, descritos nos textos em libras, tanto no nível do narrado quanto no nível da narração. Destacando, entre os enuncivos, as diferentes estratégias da língua para marcar a não-concomitância com o momento da enunciação.

\subsection{1) Os tempos enunciativos}

Feita a segmentação do texto em momento da narração e momento do narrado, o passo seguinte da análise da "História do Gibi 1" foi levantar as estratégias linguísticas e discursivas usadas para marcar o tempo, nesses dois níveis enunciativos (nos enunciados que apresentam a história e nos enunciados da história propriamente dita). Com base em outros trabalhos que descreveram o tempo em outras línguas de sinais e também em libras, a ideia foi verificar tanto 
os itens lexicais, produzidos basicamente pelas mãos, como outras marcas no olhar, na cabeça e no tronco do sinalizador, na localização dos sinais no espaço, empregadas durante a sinalização.

\subsubsection{1) Nível da narração}

Logo no início do texto "História do Gibi 1", aparece a primeira expressão temporal sinalizada manualmente. Foi o sinal AGORA (2) ${ }^{107}$, dicionarizado em Capovilla \& Raphael (2001) da forma como foi sinalizado por Celso, na figura 55.

\begin{tabular}{|l|}
\hline Figura 55: sinal AGORA (2) \\
\hline \\
\hline
\end{tabular}

Como já foi dito, nesse momento, o narrador do texto interage com seu narratário, para apresentar a história que vai contar. Na figura 56, podemos ver em que contexto, já mostrado no capítulo anterior, esse sinal de tempo apareceu.

\begin{tabular}{|c|c|c|}
\hline Figura 56: início do vídeo do texto "História do Gibi 1" - interação entre narrador e narratário \\
\hline CONHECER & PRO-FORMAL & AGORA(2) \\
\hline
\end{tabular}

A ancoragem temporal do início do texto "História do Gibi 1" é, portanto, feita pelo sinal AGORA (2), que marca tempo presente. Ocorre, nesse trecho, uma debreagem de tempo

${ }^{107}$ Como já foi dito, no capítulo 3, Capovilla \& Raphael diferenciam, em seu dicionário, o AGORA (2), produzido com as duas mãos, do AGORA (1), produzido com apenas uma mão. 
enunciativa (da enunciação). O MR instaurado é presente, concomitante ao ME. Há, então, nesse enunciado, a instauração de um sistema enunciativo de tempo a partir desse marco temporal. Também ocorre uma debreagem enunciativa de pessoa, pois, como já foi mostrado, o narrador instaura um $t u$, narratário, ao se dirigir a ele com um apontamento, e, consequentemente, um $e u$. Pode-se, portanto, dizer que esse início de texto é narrado em primeira pessoa, no tempo do presente. Há, como em todo texto debreado enunciativamente, a criação de um simulacro da enunciação. O espaço também é debreado enunciativamente, pois é instaurado um aqui da enunciação.

Ao observar atentamente o momento em que o sinalizador realiza o sinal AGORA (2), é possível perceber que, durante toda essa sinalização, tanto o tronco quanto o olhar do narrador estão direcionados ao narratário, e o sinal que marca tempo é realizado em frente ao corpo do sinalizador próximo ao seu tronco, como se pode notar, novamente, na figura 57.

\begin{tabular}{|c|}
\hline Figura 57: sinal AGORA (2) em "História do Gibi 1" \\
\hline Tronco direcionado ao narratário \\
Olhar direcionado para o narratário \\
Realização do sinal AGORA (2) \\
Sinal AGORA (2) realizado em frente e próximo ao corpo do \\
nerrador \\
Debreagem enunciativa de espaço \\
Debreagem enunciativa de tempo
\end{tabular}

Seguindo a ideia sobre a linha do tempo, defendida em trabalhos como de Alkoby (s/d) e Sinte (2013), a localização das mãos próxima ao tronco do sinalizador pode ser descrita como uma forma de marcar o presente. No texto "Metáfora - O escorpião e a tartaruga", em que os níveis enunciativos também estão explícitos, há um exemplo do uso desse mesmo sinal AGORA 
(2), para situar os eventos narrados no nível da narração no presente e uma gestualidade corporal muito próxima à do narrador de a "História do Gibi 1", como é possível observar na figura 58.

\begin{tabular}{|c|c|}
\hline \multicolumn{3}{|c|}{ Figura 58: início do texto "Metáfora - O escorpião e a tartaruga" } \\
\hline AGORA (2) & EU (realizado com as duas mãos) \\
\hline Tronco direcionado ao narratário \\
Olhar direcionado para o narratário \\
Realização do sinal AGORA (2) \\
Sinal AGORA (2) realizado em frente e próximo ao corpo do narrador \\
Debreagem enunciativa de pessoa \\
Debreagem enunciativa de espaço \\
Debreagem enunciativa de tempo \\
\hline
\end{tabular}

Em "Metáfora - O escorpião e a tartaruga", também ocorre uma debreagem enunciativa (da enunciação) de tempo, uma debreagem enunciativa de pessoa, pois há a projeção do $e u$ no enunciado, e uma debreagem enunciativa de espaço.

\subsubsection{2) Nível do narrado}

Em outro texto do corpus, "Minha Vida", que é autobiográfico, temos, de novo, as marcas de narrador em primeira pessoa expressas pela posição do tronco e a direção do olhar voltados para o narratário e o uso do apontamento $e u$, mas, nesse caso, no nível do narrado, da história propriamente dita. Também é instaurado um aqui e, portanto, também há, nesse exemplo, uma debreagem enunciativa de espaço. Os sinais também são realizados na frente e próximo ao corpo de quem sinaliza e, logo no início da história, é instaurado o tempo presente, por meio de um item lexical de tempo, o sinal HOJE (2) ${ }^{108}$, como observamos na figura 59:

${ }^{108}$ O sinal HOJE (2) é, segundo a descrição do dicionário Capovilla \& Raphael (2001), igual ao sinal AGORA (1) e JÁ. No texto "Minha Vida", ele é realizado com a mão esquerda, enquanto a mão direita da sinalizadora já se prepara para a realização do sinal que vem na sequência, que é o sinal de CASAR ou CASAD@. 


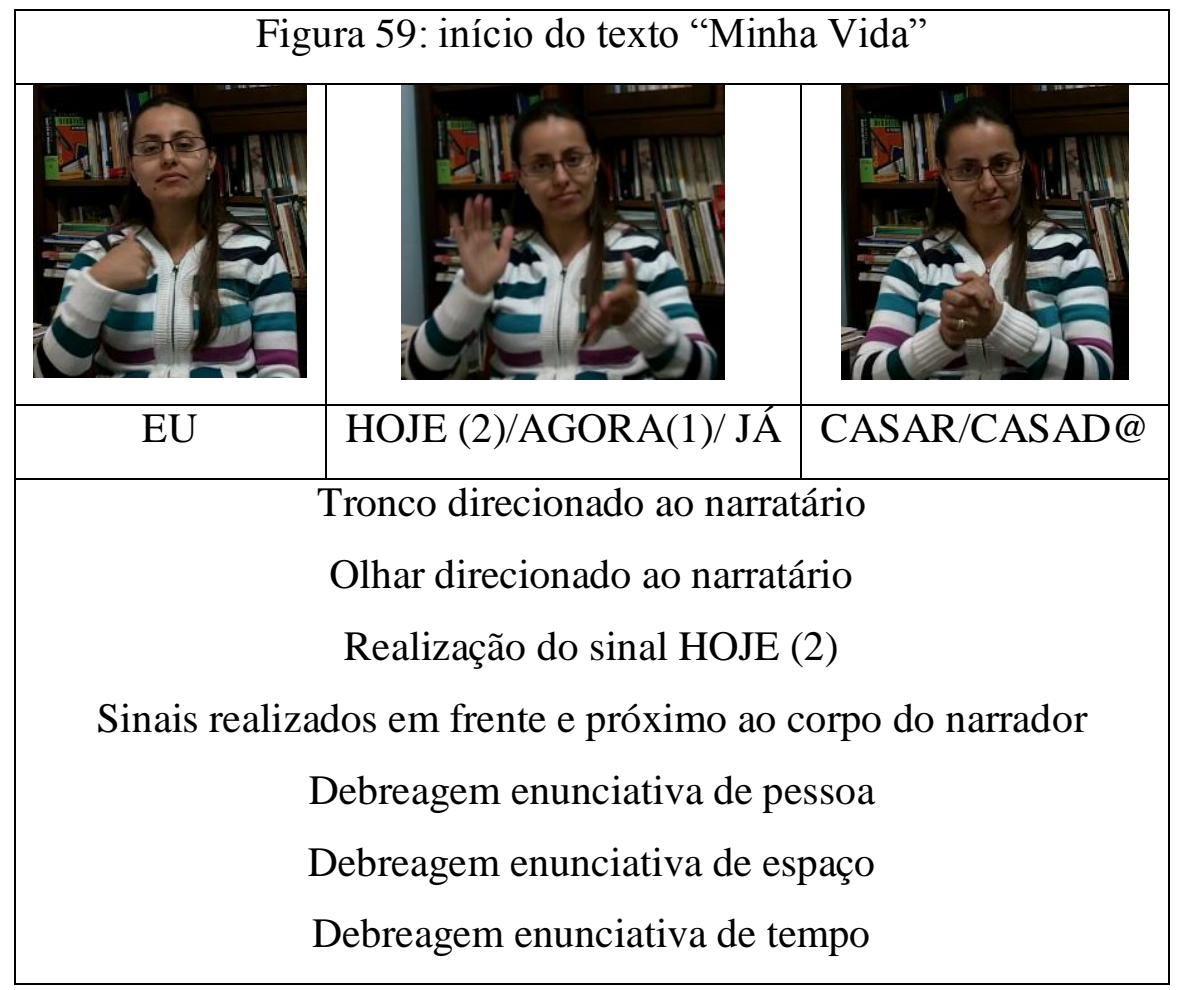

Em outro texto estudado durante a pesquisa, temos mais um exemplo de um tempo enunciativo, organizado a partir do ponto referencial presente, mas anterior a ele. Advérbios como ontem e amanhã, em português, são entendidos como formas de organizar um sistema temporal enunciativo, pois são instaurados em relação ao momento da enunciação. Em libras, o emprego do item lexical AMANHÃ pode ser entendido da mesma forma. Na figura 60, a seguir, podemos ver uma gestualidade semelhante a que ocorreu nos enunciados anteriores, mas na realização de um futuro. Mais uma vez, temos um texto em que a debreagem de tempo é enunciativa. 


\begin{tabular}{|c|c|}
\hline & Figura 60: sinal AMANHÃ \\
\hline AMANHÃ & Olhar direcionado ao narratário \\
Realização do sinal AMANHÂ \\
Sinais realizados próximo ao corpo do narrador \\
Debreagem enunciativa de pessoa \\
Debreagem enunciativa de espaço \\
Debreagem enunciativa de tempo
\end{tabular}

Na figura 61, o exemplo é do uso do sinal ONTEM. No enunciado, abaixo, é possível observar que durante a sinalização do item lexical que indica tempo passado, o tronco e olhar do narrador estão voltados para o narratário. Novamente, então, há a criação de um sistema enunciativo, pois o tempo marcado é passado em relação ao MR presente.

\begin{tabular}{|c|}
\hline Figura 61: sinal ONTEM \\
\hline Tronco direcionado ao narratário \\
Olhar direcionado para o narratário \\
Realização do sinal ONTEM \\
Debreagem enunciativa de tempo
\end{tabular}

Tanto na realização do sinal AMANHÃ, na figura 60, quanto na sinalização do sinal ONTEM, na figura 61, podemos perceber uma alteração na inclinação do tronco e da cabeça da sinalizadora. No caso do passado, o tronco inclina-se para trás e, no caso do futuro, para frente. 
Não dá, no entanto, para garantir que essa mudança no corpo seja para marcar esses tempos não concomitantes ao presente, porque os dois sinais exigem em sua realização movimentos das mãos que podem levar o corpo a alterar sua posição. De todo modo, essa gestualidade, que cria diferentes espaços, diferente do aqui, acompanha a realização desses sinais de tempo passado e futuro e, por isso, também será levada em consideração na construção do sistema temporal enuncivo.

A expressão facial e o corpo da sinalizadora só sofrem alterações, nesse texto de Neiva, quando o narrador começa, ao mesmo tempo em que narra, a simular a ação da personagem, na figura 62. O posicionamento da sinalizadora mais à esquerda, portanto, parece ocorrer para marcar pessoa, não exatamente tempo. A mudança de olhar e da direção do tronco do narrador explicita a criação, no espaço, de uma das personagens da história.

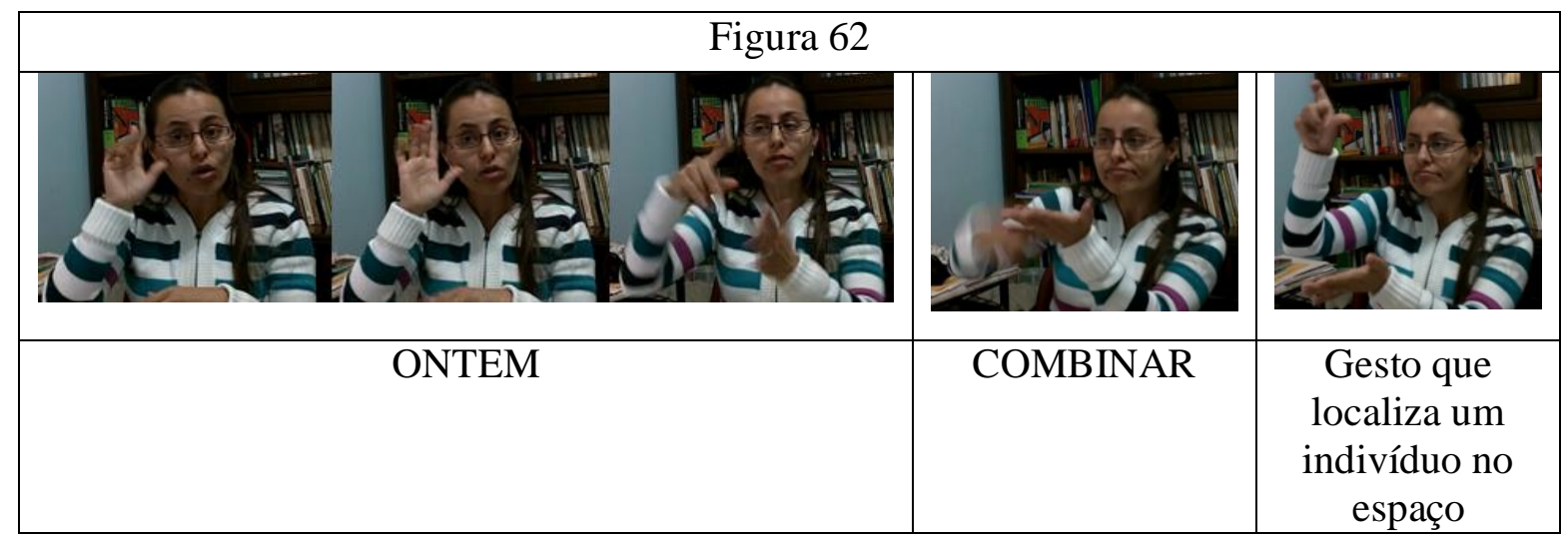

Nesse texto sinalizado por Neiva, acima, não houve a projeção do $e u$, no início. Mas, durante a sinalização, com as debreagens internas criadas, a narradora narra que um homem disse algo lhe disse algo. Nesse instante, ela usa o verbo indicador CONTAR, que é dirigido para o seu peito, marcando, assim, a primeira pessoa, na figura 63, no nível do narrado.

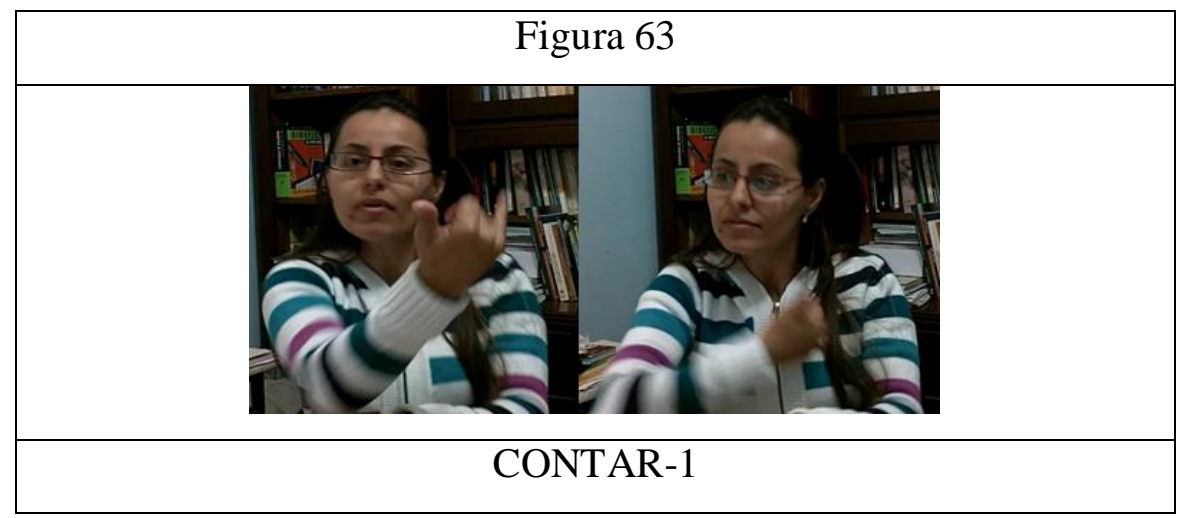


O tempo, nas debreagens internas, se não explicitado, também pode ser marcado por meio da pessoa e do espaço. Nesse caso, pode-se dizer que o sistema temporal instaurado no enunciado ilustrado na figura 63 , continua sendo enunciativo.

A seguir, apresentamos mais dados em que ocorrem debreagens internas e como o tempo é estruturado nesses casos.

\subsubsection{3) A simulação da enunciação nas debreagens internas}

$\mathrm{Na}$ "História do Gibi 1", como em outros textos da libras, ocorrem debreagens de segundo grau, que são identificadas a partir de mudanças na postura do sinalizador. Em geral, para representar os interlocutores, o narrador move os ombros, para a direita ou para a esquerda, e desvia o olhar de seu narratário. Também costuma ocorrer uma diferença na expressão facial de quem sinaliza. Os interlocutores passam a ser identificados, não só pelo local em que são representados, no espaço, como também por outros aspectos de sua gestualidade.

Também foram analisados os tempos instaurados nesses momentos da história. Para isso, primeiramente, foi necessário segmentar esses instantes e determinar o que eram os discursos citados nesse texto. Ocorrem três diálogos entre as personagens, distribuídos em três cenas da história. As primeiras falas reportadas são as do Cebolinha e da Magali, que constituem o diálogo da primeira cena. Os discursos citados da cena seguinte pertencem a Cebolinha e Cascão. O terceiro diálogo da narrativa é protagonizado por Cebolinha e por Marina e aparecem na terceira cena da história.

$1^{\text {a }}$ Debreagem de segundo grau: diálogo entre Cebolinha e Magali

Para construir o primeiro diálogo, o narrador representa a personagem Cebolinha, à sua direita, olhando para a esquerda, e Magali, à sua esquerda, com expressão facial de tristeza, como se pode ver na figura 64: 
Figura 64: diálogo entre o Cebolinha e a Magali

\begin{tabular}{|c|c|}
\hline Cebolinha & Magali \\
\hline & \\
\hline AJUDAR & PRO-1 (mão direita) e ARVORE (mão esquerda) \\
\hline
\end{tabular}

$2^{\mathrm{a}}$ Debreagem de segundo grau: diálogo entre Cebolinha e Cascão

Para construir o segundo diálogo da história, o narrador representa a personagem Cebolinha, novamente à sua direita, olhando para a esquerda, e Cascão, à sua esquerda, como podemos ver na figura 65 :

\begin{tabular}{|c|c|}
\hline \multicolumn{2}{|c|}{ Figura 65: diálogo entre o Cebolinha e o Cascão } \\
\hline Cebolinha & Cascão \\
\hline & \\
\hline AJUDAR & OBRIGAD@ \\
\hline
\end{tabular}

$3^{a}$ Debreagem de segundo grau: diálogo entre Cebolinha e Marina

No terceiro diálogo da narrativa, o narrador dá a voz a Cebolinha, representando-o do lado esquerdo, e dá a voz à Marina, à sua direita, novamente com expressão facial de tristeza, como mostra a figura 66: 


\begin{tabular}{|c|c|}
\hline \multicolumn{2}{|c|}{ Figura 66: diálogo entre o Cebolinha e a Marina } \\
\hline Marina & Cebolinha \\
\hline & \\
\hline
\end{tabular}

Nos diálogos da "História do Gibi 1", o MR instaurado inicialmente é presente, ou seja, as debreagens temporais, nesses momentos, são enunciativas. Uma evidência de que se trata de um tempo do agora é justamente o posicionamento do tronco e a direção do olhar do sinalizador. Para interpretar cada uma das personagens, ele assume um espaço diferente e, para simular a interação entre eles, mostra-os se olhando. O olhar e o tronco direcionados ao interlocutário indicam que o tempo instaurado nessa parte do texto é um tempo do sistema enunciativo, pois há, nesse momento, simulação de uma enunciação.

Os enunciados produzidos pelas personagens, no entanto, podem conter mais tempos e, no decorrer do texto, mudar o ponto de referência a partir do qual se organizam temporalmente. No interior dos diálogos, então, teremos novamente novas situações, novos enunciados para analisar. Cada personagem que toma a palavra se torna um narrador. A questão que se levanta, então, é sobre as marcas que aparecem nesses enunciados das personagens para indicar presente, passado e futuro. Uma hipótese forte é a de que elas sejam as mesmas que apareceram no nível do narrado. No nível da narração, foi frequente o uso de marcas lexicais manuais para indicar o momento de referência.

No trecho do encontro do Cebolinha com a Magali, no texto da história em quadrinhos, aparece o recurso visual do balão que contém uma imagem. É nele que se encontra a causa do choro da personagem. Na cena da Magali, o motivo do choro tem a ver com um acontecimento presente: o fato de ela estar com fome e não alcançar as maçãs na árvore, que está ao lado dela, no mesmo tempo e espaço de sua enunciação. A personagem até aponta para a árvore cheia de maçãs. O balão da Magali contém as próprias maçãs, também presentes no momento e espaço de sua enunciação, como podemos verificar na figura 67 a seguir. Nesse diálogo da Magali, no gibi, 
o MA é concomitante ao MR, ou seja, o que é narrado está acontecendo no mesmo momento em que ela o narra:

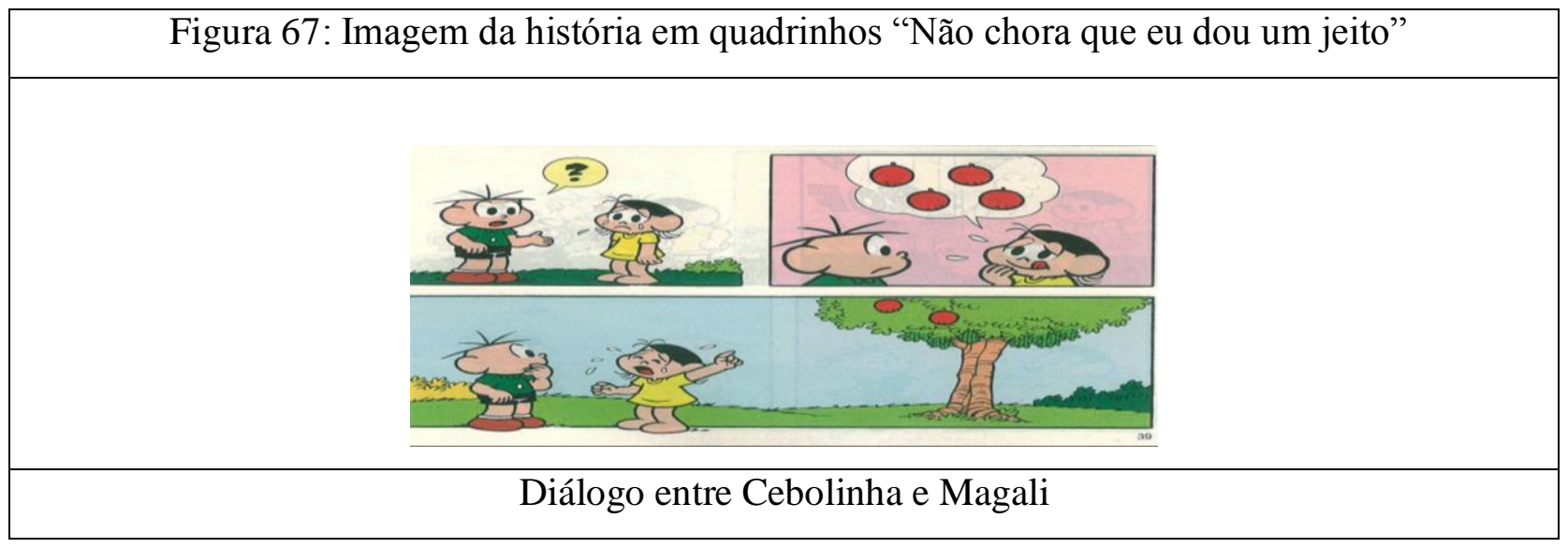

Em uma história contada em português a partir dessa mesma história em quadrinhos de Maurício de Souza, a narradora utiliza o presente, no momento em que reporta a fala de Magali e a fala de Cebolinha ${ }^{109}$. No texto oral, representado pela foto abaixo, contado em português pela ouvinte Ana Seelaender, a narradora diz "Cebolinha encontra com a Magali chorando" e simula o choro da Magali, dando voz, portanto, a essa personagem. Também ocorre uma debreagem interna nessa história, e a instauração de pessoa, espaço e tempo, nesse nível da enunciação. $\mathrm{Na}$ figura 68, abaixo, é possível ver um momento em que a narradora do texto em português, como o Celso fizera em sua sinalização, demonstra a ação da personagem, ao mesmo tempo em que conta que a Magali estava chorando. Esse sincretismo de personagem e narrador evidencia a passagem de uma instância enunciativa a outra.

\footnotetext{
${ }^{109}$ Existem dois textos orais, em português, gravados e que foram eliciados a partir da mesma história em quadrinhos sem fala que estimulou o texto em libras "História do Gibi 1": um contado por Ana Seelaender, e a outro, contado por Thiago Bolgueroni. Este vídeo de Ana também se encontra no DVD em anexo a esta tese.
} 


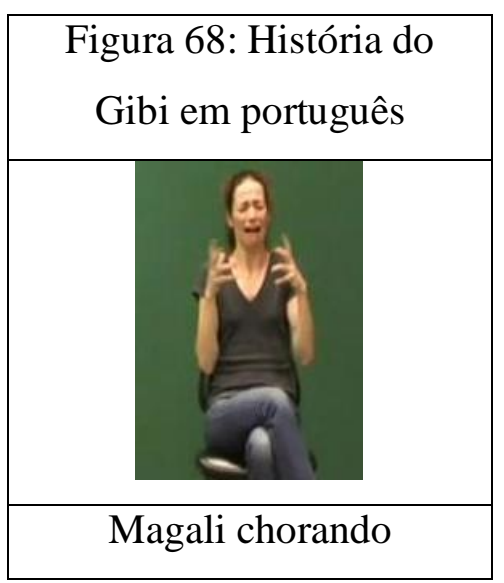

É interessante notar, ainda, que, do mesmo jeito que acontece no texto em libras, a narradora desse texto em português também aponta para espaços ao seu redor, na figura 69, abaixo, para se referir a algo do cenário, por exemplo. Nesse trecho de seu discurso, ela aponta para onde foi colocada a árvore no cenário que criou à sua volta.

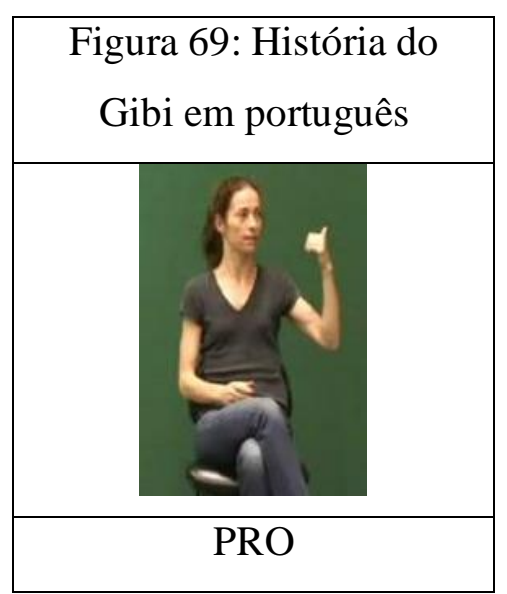

Da mesma forma que nas línguas de sinais, quando se conta uma história em português oralmente, é possível valer-se de uma gestualidade pantomímica, para simular as ações das personagens, como na figura 68, e partes de uma história, como na figura 69 . Também se pode apontar para o espaço ao redor do corpo, uma vez que também se pode criar nele o cenário do que é narrado.

Nos três textos (em língua de sinais, contado por Celso, em quadrinhos e em português oral, contado pela Ana), é possível perceber que a cena da Magali é narrada, no presente, e que, tanto a pessoa quanto o espaço, instaurados nesses discursos, são também debreados enunciativamente. 
No trecho sinalizado da fala da Magali, nas figuras 70 e 71, a seguir, a sinalização é feita mais próxima ao corpo do sinalizador, mais para sua esquerda, onde foi representada a personagem, desde o início da história. A árvore é criada no espaço de sinalização, do lado esquerdo do corpo do sinalizador, ou seja, do lado esquerdo da personagem Magali (observar figura 70) ${ }^{110}$. Isso é feito quando a própria personagem conversa com o Cebolinha. Ela faz o sinal árvore e se refere a ela olhando para uma parte do sinal que fica "congelado" pela sua mão esquerda, em vários momentos de sua fala (observar figuras 70 e 71, abaixo). Como Celso realiza toda essa sinalização, no papel de Magali, com expressão facial e posição do corpo próprias da personagem, é mais fácil entender que toda sinalização é a fala da Magali. Ocorre uma debreagem enunciativa de pessoa. Em relação ao tempo, o MA é concomitante ao MR. Os sinais são realizados próximos ao corpo, não houve inclinação do corpo para trás ou para frente.

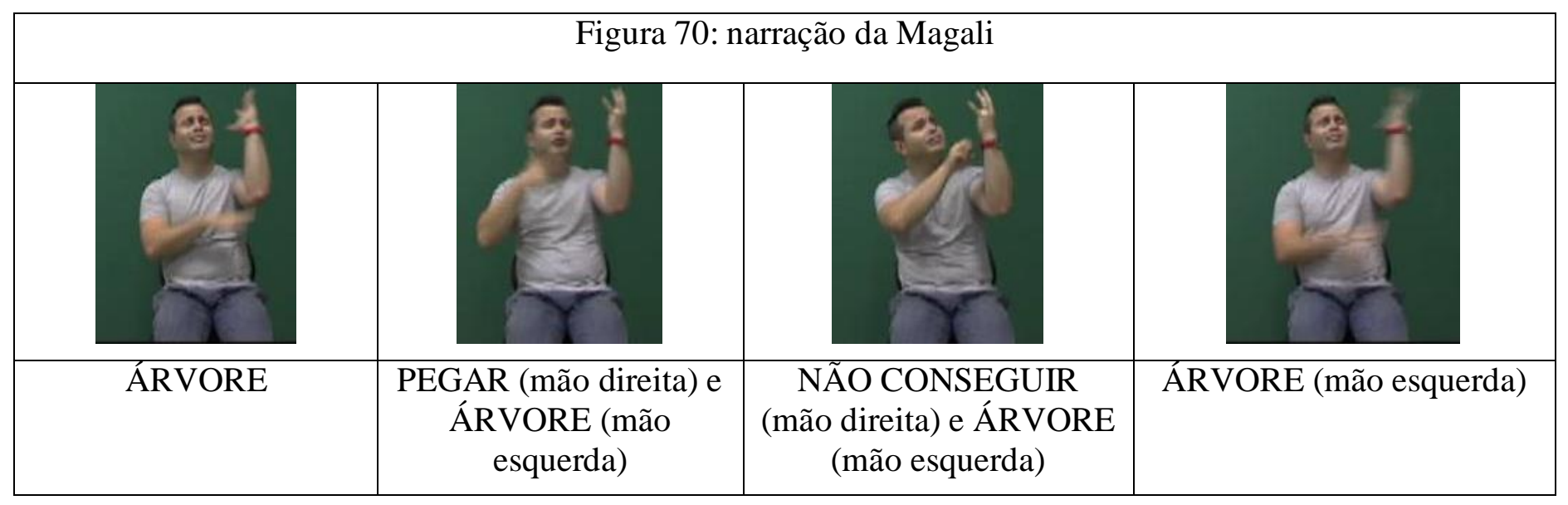

\begin{tabular}{|c|c|c|c|}
\hline \multicolumn{5}{|c|}{ Figura 71: Narração da Magali } \\
\hline & & \\
\hline
\end{tabular}

${ }^{110} \mathrm{~A}$ árvore, na história de Maurício de Souza, também se encontra à esquerda da personagem. 
Em toda a cena da Magali é instaurado, então, um sistema temporal enunciativo, em que o MR é concomitante ao ME, pois é o momento da conversa entre Magali e Cebolinha, e o MA é também concomitante ao MR, portanto, um presente. Como não há um sinal lexical que indique de fato que o MR, nesse trecho da história, é presente, podemos dizer que o tempo é marcado por uma embreagem heterocategórica, ou seja, há uma neutralização das categorias enunciativas, e o tempo é construído a partir da instauração da pessoa e do espaço. Tanto a debreagem de pessoa quanto a debreagem de espaço, nos enunciados da Magali, são enunciativas e, portanto, o tempo poderia ser entendido como enunciativo a partir dessas outras categorias discursivas. Isso será mais desenvolvido adiante.

No texto "Metáfora - O escorpião e a tartaruga", também há debreagens internas, no nível do narrado. Primeiramente, há um diálogo entre o pai de Rimar e a filha, depois, do pai com outra pessoa (o que é reportado rapidamente pelo narrador). Em seguida, um diálogo entre a irmã de Rimar e um homem de seu trabalho, e, por fim, as interações entre o escorpião e a tartaruga. Na figura 72, podemos observar um trecho desse discurso direto, em que o escorpião toma a palavra e pede ajuda à tartaruga. Para isso, o narrador se posiciona à esquerda e demonstra a personagem escorpião, perguntando se a tartaruga pode ajuda-lo. À direita, o narrador demonstra a personagem da tartaruga.

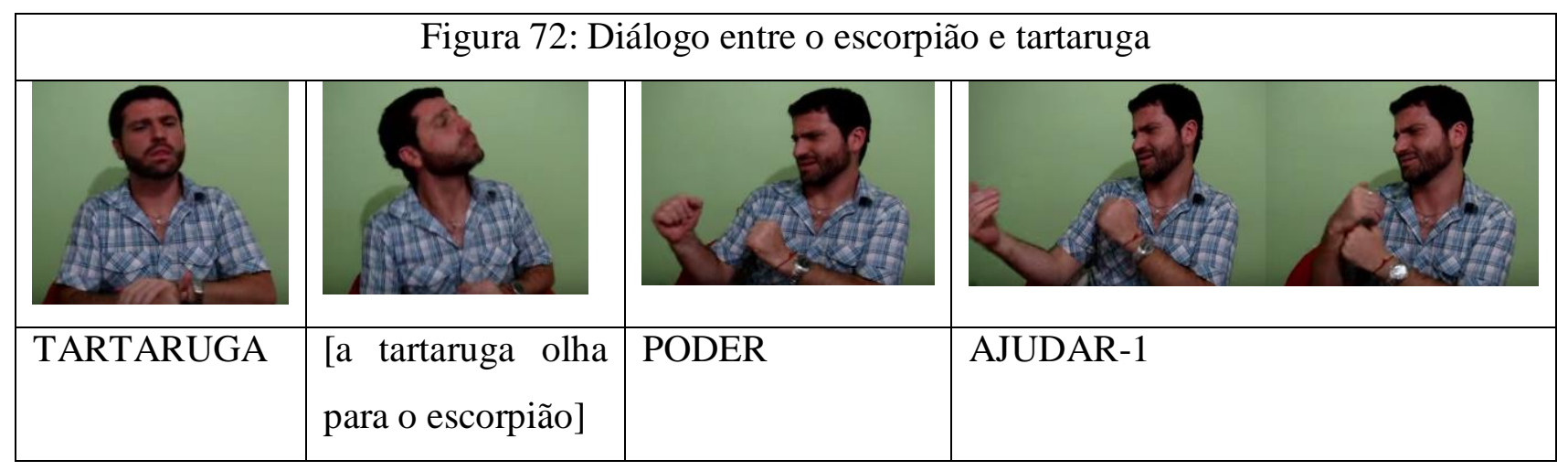

Na figura 72, acima, é possível ver que os interlocutores da história se olham, estão voltados um para o outro, em uma interação realizada em primeira pessoa, já que há o uso de um verbo indicador que instaura um eu e um tu. Novamente, há uma simulação de enunciação e a debreagem temporal pode ser considerada enunciativa, se também considerarmos que o olhar e o tronco direcionado para o interlocutário e sinais realizados próximos ao corpo do sinalizador indiquem tempo presente. 
Como na "História do Gibi 1" e "Metáfora - O escorpião e a tartaruga", nos textos "História do Gibi 2", "O amor é surdo", "Minha Vida", "Sonhos", "Sonho com um carro novo", também ocorrem muitos diálogos, debreagens de segundo grau, em que há uma simulação do ME. O MR instaurado, nesses momentos de discurso direto, é também presente e a história se apresenta como se estivesse acontecendo no momento da enunciação, enquanto ela é narrada, em frente aos nossos olhos, como se fosse um filme.

Em outros dois momentos da história em quadrinhos, de Maurício de Souza, em que ocorrem os diálogos entre as personagens, notamos que, diferentemente do que aconteceu nas falas da Magali e do escorpião, acima, há o uso de um recurso visual diferente, para se reportar ao passado, ainda do sistema enunciativo: o da conversa do Cebolinha com o Cascão, que conta o que aconteceu com sua bola, e o momento da conversa do Cebolinha com a Marina, que conta o que aconteceu com seu desenho. Como a história não tem falas, foi desenhado um balão que possui, ao invés de palavras, a imagem do que ocorreu, como se fosse um balão de pensamento. O balão, no entanto, tem formato de balão de fala e é usado como tal, como aconteceu no caso do diálogo entre o Cebolinha e a Magali. Isso pode ser verificado nas imagens a seguir, na figura 73.

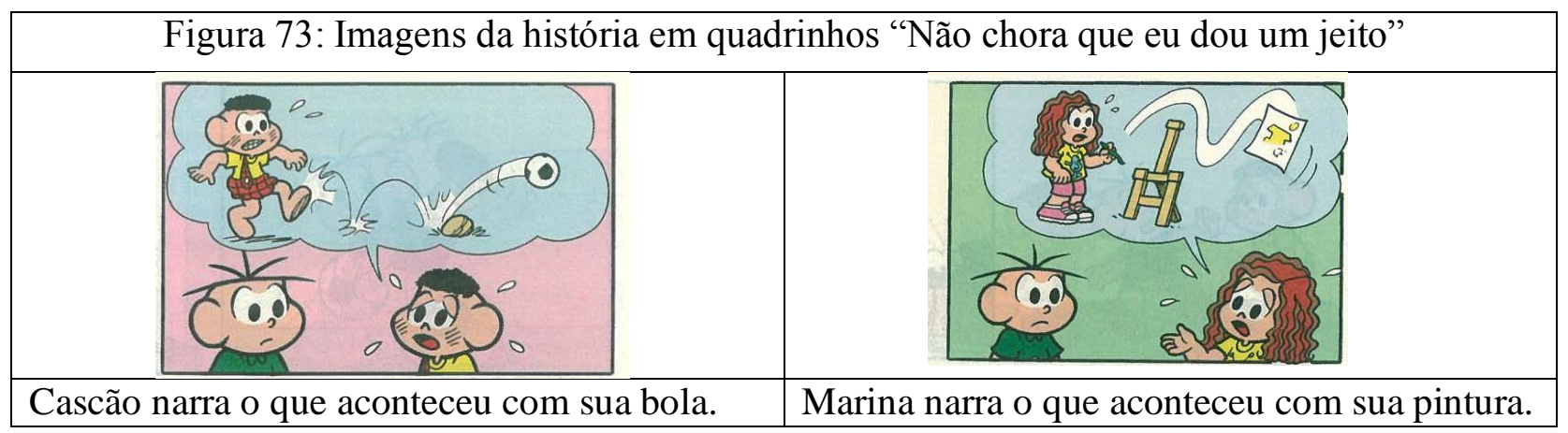

$\mathrm{Na}$ "História do Gibi 1", os dois trechos aparecem e são entendidos da mesma maneira, ou seja, quem assiste ao vídeo entende que o Cascão e a Marina não estão realizando as ações de jogar bola e pintar, respectivamente, no momento em que se encontram com o Cebolinha. Na narração em português, as falas do Cascão e da Marina estão no passado, marcando uma não concomitância das ações narradas com o MR instaurado no texto ${ }^{111}$. Esse tempo é explicitado na flexão dos verbos usados por Ana. A diferença entre a narração sinalizada e interpretada em

\footnotetext{
${ }^{111}$ Além da história do gibi contada em português por Ana Seelaender, temos gravada uma interpretação feita por Neiva de Aquino Albres da história sinalizada por Celso Badin. Na sua interpretação desses dois momentos da "História do Gibi 1", Neiva narrou as falas das personagens usando o pretérito imperfeito. As falas da Magali, entretanto, foram narradas no presente.
} 
português é que, na "História do Gibi 1", como na história em quadrinhos de Maurício de Souza, há outros tipos de marcação que fazem essa diferença entre os momentos dos acontecimentos reportados nos diálogos entre Cebolinha, Magali, Cascão e Marina.

Uma diferença que é possível notar entre os três discursos diretos sinalizados por Celso (Cebolinha-Magali, Cebolinha-Cascão e Cebolinha-Marina), em "História do Gibi 1", é a maneira como é reportada a fala de cada uma das personagens. Como já foi dito, nas línguas de sinais, o discurso citado é introduzido no texto muitas vezes, e há, nesse instante, uma mistura de narrador e personagem, de discurso citado com a do discurso citante. Como mostrado anteriormente, mudanças no torso, nos ombros, na cabeça e no olhar do sinalizador podem apontar mudanças entre essas instâncias enunciativas.

No trecho do Cascão, a cena é sinalizada de forma um pouco diferente da sinalização da cena da Magali. Cascão precisava contar para o Cebolinha o que tinha acontecido antes de ele chegar ali. Quando o Cebolinha encontra o Cascão, encontra-o chorando, e não jogando bola. Cebolinha pergunta a Cascão por que ele está triste. E, ao responder, Cascão conta o que tinha acontecido anteriormente a essa cena da conversa.

Como já foi dito, cada personagem é representada em um lado, um, à esquerda, e o outro, à direita. $\mathrm{O}$ sinalizador, inicialmente, inclina seu corpo e olha para a esquerda, quando o Cebolinha pergunta a Cascão o que havia acontecido. Em seguida, o sinalizador vira seu corpo para a direita, para simular a fala de Cascão, que explica o que ocorrera. Na figura 74, é possível ver as fotos desse momento da interação entre as duas personagens.

\begin{tabular}{|l|l|}
\hline \multicolumn{2}{|c|}{ Figura 74: debreagem de segundo grau: interação entre Cebolinha e Cascão } \\
\hline Cebolinha & \\
\hline \multicolumn{1}{|c|}{ Cascão } \\
\hline $\begin{array}{l}\text { Deslocamento do corpo para a direita } \\
\text { Movimento da cabeça: direcionada para o } \\
\text { interlocutor Cascão } \\
\begin{array}{l}\text { Direção do olhar: para o interlocutor } \\
\text { Movimento da cabeça: direcionada para }\end{array} \\
\text { interlocutor Cebolinha } \\
\text { Direção do olhar: para o interlocutor }\end{array}$ \\
\hline
\end{tabular}


Quando o Cascão toma a palavra, se transforma em narrador de sua história e conta ao Cebolinha o que aconteceu com sua bola. Há uma debreagem enunciativa de pessoa, de espaço e de tempo nesse instante, porque Cascão narra sua história na primeira pessoa, no espaço do aqui e se refere a um acontecimento anterior ao MR presente. Na figura 75, podemos ver as imagens dessa fala do Cascão e o momento inicial, quando ele faz o sinal de $e u$.

\begin{tabular}{|c|c|c|c|}
\hline \multicolumn{4}{|c|}{ Figura 75: Narração do Cascão } \\
\hline$\sigma^{2}$ & & & $y$ \\
\hline $\mathrm{EU}$ & BRINCAR & FUTEBOL & BOLA \\
\hline 218 & & & \\
\hline trajetória da bola & $\widehat{A} G U A$ & $\begin{array}{l}\text { desenho com as mãos do } \\
\text { espaço onde há água }\end{array}$ & a bola afundando \\
\hline
\end{tabular}

A descrição feita pela sinalização do Cascão como narrador é mais distanciada do corpo do sinalizador do que foi a sinalização da Magali. Há uma inclinação do corpo do sinalizador para trás, quando ele interpreta a fala do Cascão e narra que a bola que caíra no lago durante o jogo de futebol. O olhar está voltado para as mãos, e, portanto, desviado do narratário. Diferentemente das ações do Cebolinha, nos trechos do diálogo com a Magali, nesses trechos narrados na figura 75, como sendo a fala do Cascão contando o que acontecera com a bola, podemos observar que os sinais são realizados mais à esquerda do sinalizador, em um espaço que foi construído como sendo do passado, anterior ao momento em que os meninos se encontram e conversam $^{112}$. É possível pensar que, nessa sinalização, a linha de tempo que é construída no espaço é a anafórica, que, segundo Johnston \& Schembri (2007) é aquela que cruza o corpo na diagonal, e é usada de tal forma que seus elementos podem ser retomados a todo instante na história.

${ }^{112}$ Agradeço à Thaís Bolgueroni por essa observação sobre esse exemplo. 
Neste momento da fala do Cascão, o tempo instaurado é enunciativo, como o de outros diálogos da história. O MR continua sendo o presente da enunciação: o momento em que os meninos estão conversando, e Cebolinha questiona o motivo da infelicidade de Cascão. O MA narrado pelo Cascão, no entanto, não parece ser concomitante a esse MR, como era o caso da narração feita pela Magali. Embora não seja marcado lexicalmente, o MA desse trecho da fala do Cascão pode ser interpretado como anterior ao MR, portanto, um passado desse sistema temporal enunciativo. As marcas dessa anterioridade parecem ser, como já foi dito, o deslocamento do tronco do sinalizador para trás, o olhar desviado do narratário, como se pode notar na figura 76.

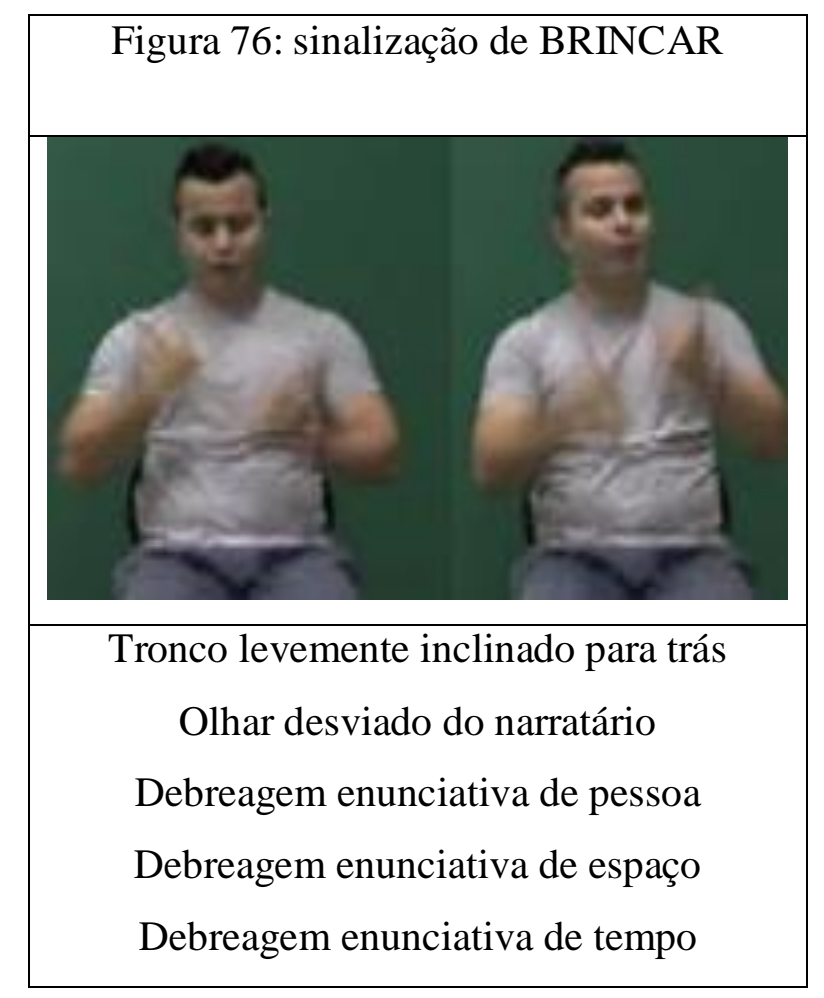

No trecho do diálogo entre o Cebolinha e a Marina, temos uma situação semelhante a da que ocorre com a cena do Cascão. Cebolinha encontra Marina chorando e lhe pergunta o que houve. A garota começa sua narração. Como na cena do Cascão, há uma debreagem enunciativa de pessoa, pois a Marina também narra sua história em primeira pessoa (o narrador também realiza o sinal de eu). Ela conta ao Cebolinha que está triste, porque a folha onde desenhava foi parar em cima do telhado de uma casa, após uma ventania muito forte. Novamente, os fatos narrados não são concomitantes ao momento de enunciação. Eles aconteceram antes de o Cebolinha encontrá-la e conversar com ela. 
Como nos demais diálogos, então, temos um MR concomitante ao ME, mas, como no caso da narração do Cascão, temos um MA anterior a esse MR. A sinalização de Marina, como foi o caso da do Cascão, também é mais distanciada do corpo do sinalizador e ocorre mais à esquerda do espaço de sinalização, de forma diferente daquele em que as ações do Cebolinha ou do próprio diálogo entre as personagens é mostrado. Na figura 77, podemos observar as falas da Marina que constituem essa pequena narração dela de um acontecimento no passado:

\begin{tabular}{|c|c|c|c|}
\hline & \multicolumn{3}{|c|}{ Figura 77: Narração da Marina } \\
\hline EU & TRISTE & PORQUE & PINTAR \\
\hline 7 & 3 & & \\
\hline AZAR & VENTAR & PAPEL [voando] & CASA \\
\hline
\end{tabular}

Como na cena do Cascão, na narração da Marina, há a sinalização de um MA anterior ao MR instaurado nessa parte do texto. E as marcas dessa anterioridade também podem ser notadas, na figura 77, acima, quando o narrador dá a voz à Marina. O corpo e o olhar do sinalizador sofrem alterações. O narrador, durante todo esse trecho, olha para o narratário várias vezes, o que parece ser uma forma de marcar sua voz constantemente, mas, durante a realização de muitos sinais, os olhos se voltam para as mãos, para o cenário, para os objetos demostrados em cena. Na figura 78, podemos ver isso acontecer, na realização do sinal PINTAR ${ }^{113}$.

${ }^{113}$ É importante mencionar que, para realizar o sinal PINTAR em libras, em geral, os olhos são direcionados para as mãos (para o que se pinta). O olhar estar voltado para baixo, local das mãos, nesse caso, pode ser motivado por essa questão articulatória do sinal, e não exatamente para marcar a não-concomitância, muito embora, em toda cena da figura 78, o olhar do narrador sofra muitas alterações, desviando sempre do narratário, e não apenas na realização do sinal PINTAR. 


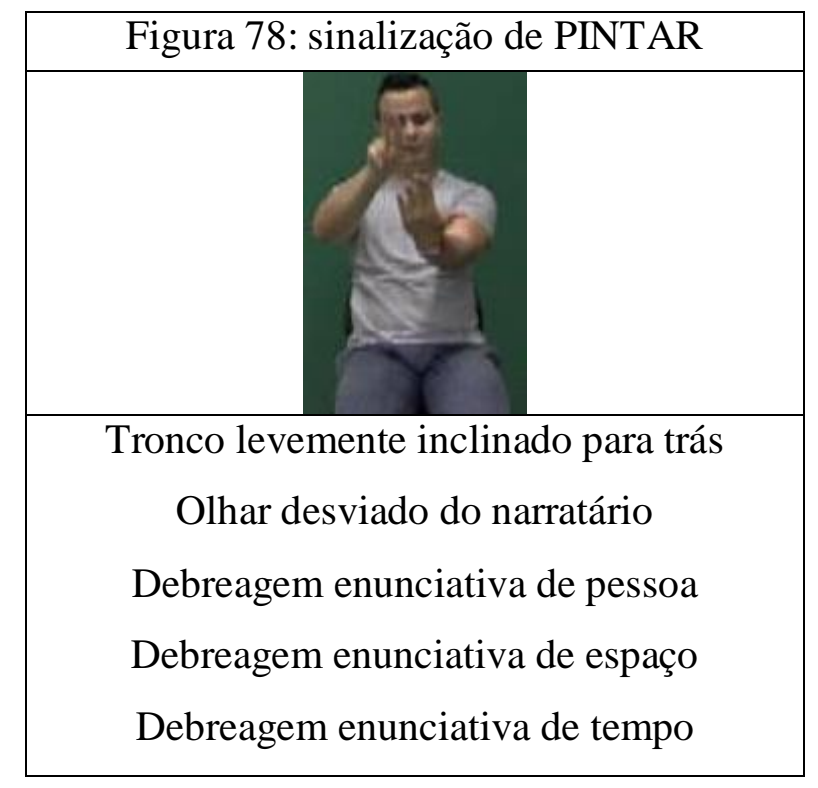

Por se tratar de uma debreagem de segundo grau, tem-se, nos três diálogos de a "História do Gibi 1", um MR presente (igual ou concomitante ao ME). O que varia é o MA nos enunciados que compõem as falas das personagens. Nos dois últimos casos, do Cascão e da Marina, temos um MA que é anterior ao MR (o ocorrido não é concomitante ao momento em que as personagens se encontram e conversam na história) enquanto que, no da Magali, como já foi dito, o MA é concomitante ao MR presente.

Nas debreagens de segundo grau do texto "História do gibi 2", também há a instauração de um MR presente, pois há uma simulação do momento da enunciação nos diálogos entre as personagens. No momento em que o Cascão e a Marina tomam a palavra e narram o que tinha acontecido antes de sua conversa com o Cebolinha, o narrador faz o sinal CONTAR, em cada um dos momentos, em que a fala dessas duas personagens é narrada.

Nas figuras 79 e 80, abaixo, podemos ver, respectivamente, o momento em que, na narração do Cascão e na narração da Marina, a sinalizadora realiza o sinal CONTAR, com movimento duplicado, com o tronco levemente inclinado para trás e o olhar desviado do narratário (os olhos estão quase fechados). O enunciado que compõe essa fala, nos dois casos, encontra-se em um tempo passado, anterior ao MR presente, instaurado na construção desses diálogos, e, por isso, há marcas de não-concomitância com o ME, como a leve inclinação do tronco e o desvio do olhar do sinalizador. Pode-se tratar, portanto, também de um tempo de um sistema temporal enunciativo. 
Figura 79: Narração do Cascão

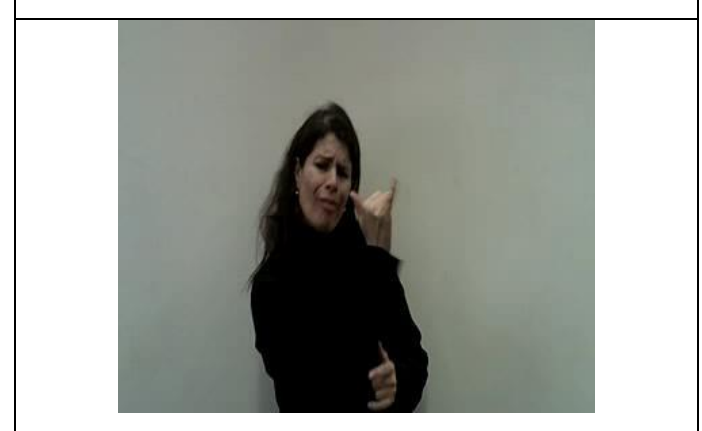

Tronco levemente inclinado para trás

Tronco e olhar desviados do narratário

Debreagem enunciativa de pessoa

Debreagem enunciativa de espaço

Debreagem enunciativa de tempo

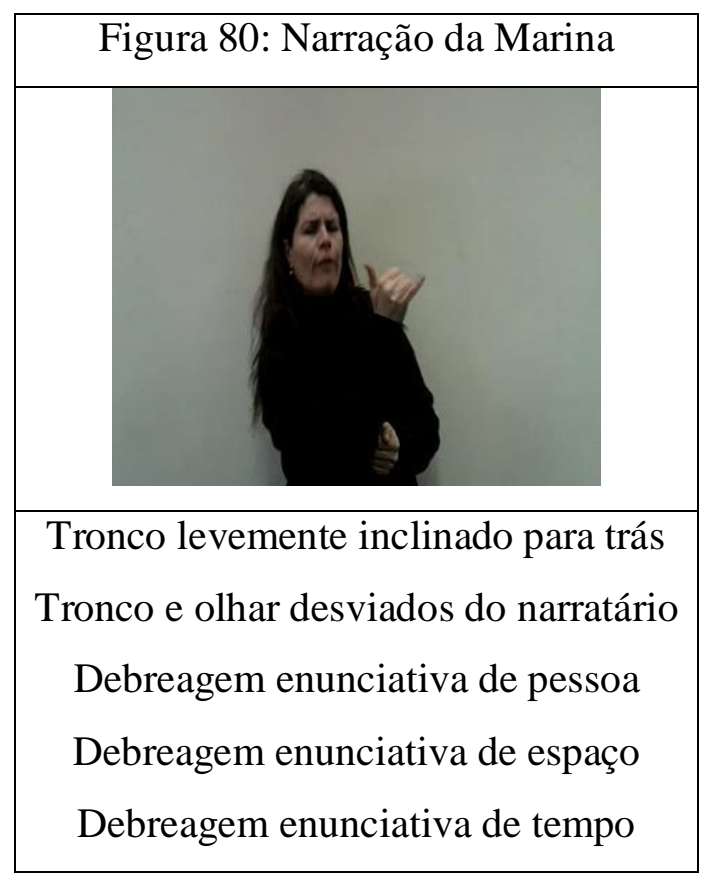

Outro exemplo relacionado à marcação do tempo nos enunciados de uma personagem, em um diálogo, está no texto "Metáfora - O escorpião e a tartaruga". Como já foi dito, há um momento, nesse discurso, em que o narrador dá a voz às personagens do escorpião e da tartaruga e eles interagem. O MR instaurado na construção desse discurso direto também é presente, como já foi mostrado. Mas, durante a fala deles, outros MR são instaurados. Na fala do escorpião, por exemplo, ocorre uma instauração do tempo futuro. Como nos exemplos anteriores, da "História 
do Gibi 1", não há a realização de um item lexical que indica esse tempo. As marcas de tempo no enunciado serão todas de outro tipo, em especial, no texto do Rimar, a localização das mãos distante do corpo, à frente, e a inclinação do tronco do sinalizador, para a direita e para frente. $\mathrm{Na}$ figura 81, podemos ver um enunciado que faz parte da fala do escorpião.

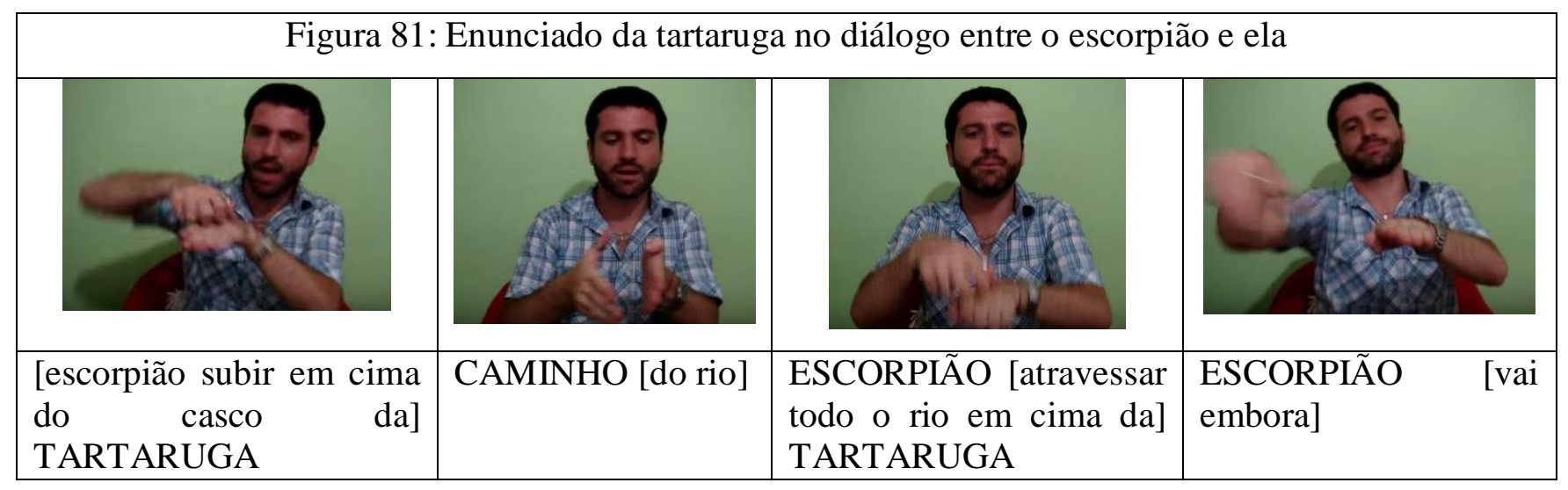

O escorpião tenta convencer a tartaruga a levá-lo em seu casco, para atravessar o rio. Para isso, ele lhe diz como será a travessia, para mostrar que nada de ruim acontecerá a ela. Quando ele narra o que vai acontecer, está construindo no texto um MA que é posterior ao MR presente (o ponto referencial a partir do qual o diálogo entre eles foi construído). Para marcar essa nãoconcomitância com o presente, o narrador volta a olhar para seu narratário e corpo na posição neutra, no início desse enunciado, marcando a fala do narrador, e, depois, descreve como seriam as ações. Enquanto sinaliza parte de seu texto, seus olhos se voltam para as mãos, que estão o tempo todo distanciadas do corpo do sinalizador, e seu corpo se inclina para a direita, onde no texto havia sido construída a personagem do escorpião, o que marca provavelmente que a narração é dele. Como a ação que está sendo descrita envolve movimento, fica difícil afirmar que as mãos estão se distanciando para marcar o tempo futuro necessariamente. Mas percebemos que o que foi sinalizado não aconteceu na história, porque houve uma mudança na postura da narração que, até então, estava sendo usada. Novamente, temos um sistema temporal enunciativo organizando as relações desse texto.

As falas das personagens, no entanto, nem sempre se apresentam organizadas a partir de um ponto de referência presente nos textos. Na seção a seguir, são apresentados exemplos em que os enunciados apresentam tempos enuncivos, não concomitantes ao $\mathrm{ME}$, em alguns discursos analisados neste trabalho. 


\subsection{2) Os tempos enuncivos}

Como foi dito, nos textos analisados, também foi possível observar a instauração de tempos enuncivos, ou seja, os tempos que se organizam a partir de um marco temporal pretérito ou futuro. Esses tempos, não concomitantes com o ME, aparecem sempre bem marcados, por itens lexicais, que indicam o passado ou o futuro, por elementos da língua produzidos pelos gestos corporais, como movimento do tronco, direção do olhar e localização das mãos no espaço de sinalização, ou ainda por todo esse conjunto de estratégias linguísticas e discursivas que, na língua, são responsáveis por construir lugares no espaço associados à pessoa ou a tempo. Os tempos enuncivos podem aparecer na narração, quando o narrador instaura categorias de pessoa ou de espaço, tanto enunciativas quanto enuncivas, por meio de debreagens de primeiro grau.

A seguir, são apresentados exemplos da instauração de tempo passado e, depois, de tempo futuro, todos enuncivos e do nível do narrado, nos textos do corpus.

\subsubsection{1) Tempo passado}

Diferentemente do que ocorre na "História do Gibi 1", "Minha Vida" e "Metáfora - O escorpião e a tartaruga", por exemplo, na nova versão do texto "O amor é surdo", sinalizado por Celso Badin, o sinalizador inicia a narração, instaurando o momento de referência passado (tempo não concomitante ao momento de enunciação), pois seu primeiro sinal já é PASSADO e, em seguida, a expressão linguística formada pelos sinais ANO e ATRÁS (2). Na figura 82, temos as imagens que registram o momento inicial do texto, em que o narrador diz algo como "há muitos anos" ou "era uma vez...".

\begin{tabular}{|l|l|l|}
\hline \multicolumn{3}{|c|}{ Figura 82: início do texto "O amor é surdo" } \\
\hline & & \\
\hline & ANO(S) & ATRÁS (2) \\
\hline
\end{tabular}

Como nos outros textos analisados, o sinalizador assume o papel de narrador (direciona o seu tronco e seu olhar para seu narratário, no final da sinalização que aparece na figura 82). 
Depois de marcar o tempo, faz uma debreagem enunciva de espaço e de pessoa, e instaura tanto o espaço do lá (um castelo) quanto a terceira pessoa, como é possível ver na figura 83, quando o narrador faz o sinal de BEBÊ, olhando para o narratário, e demonstrando, assim, a mulher que segura o seu filhos nos braços.

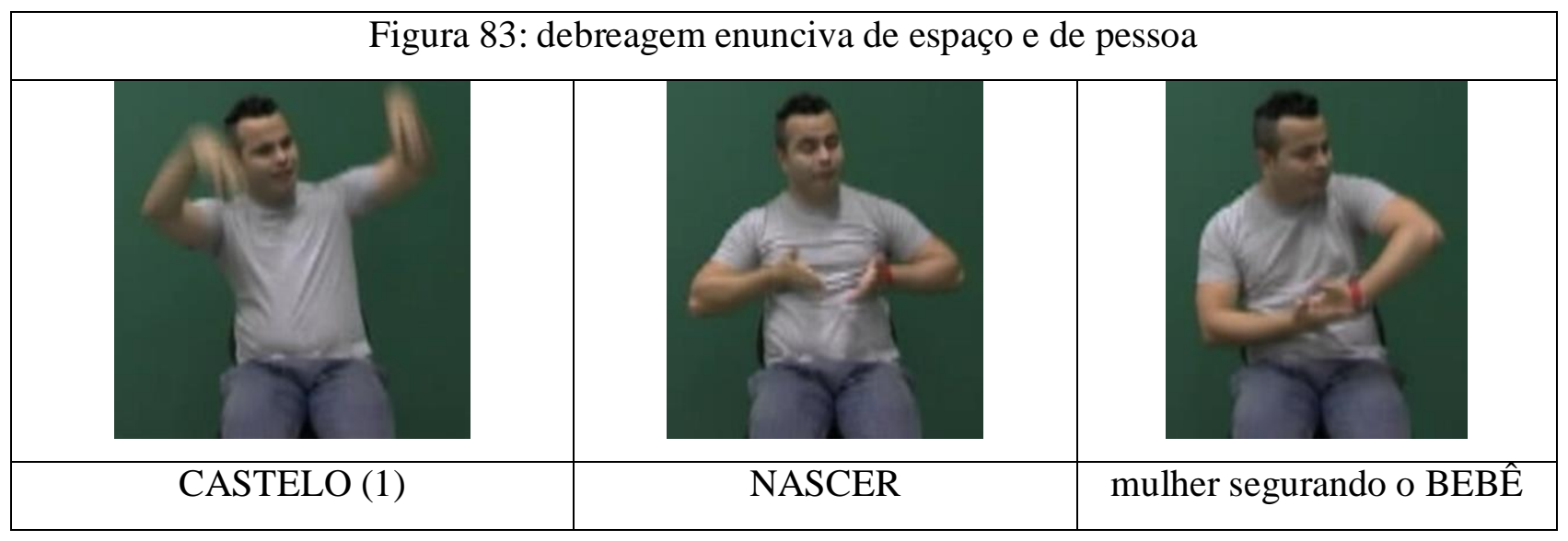

Toda a sinalização apresentada na figura 83 é realizada com o tronco do sinalizador inclinado para a esquerda, e não em uma posição neutra, que pode marcar categorias enunciativas como eu, aqui e agora. E, na figura 84, podemos ver que, durante a realização dos itens lexicais que indicam tempo, podemos observar que as mãos que realizam o sinal ANO(S), por exemplo, são posicionadas mais acima, na região do ombro direito do sinalizado, em que será realizado o sinal de PASSADO. O sinal de PASSADO é realizado com as mãos se dirigindo para a região que fica atrás do corpo do sinalizador, nessa localização, acima do ombro direito. O sinal $\mathrm{ANO}(\mathrm{S})$, que poderia ser localizado mais abaixo, não é produzido na frente do corpo do sinalizador, mas sim, mais para cima e para trás, na região do espaço em que foi sinalizado PASSADO. Quando o narrador realiza esses itens lexicais, também é possível perceber que o olhar se desvia do narratário e o tronco se inclina para trás. 


\begin{tabular}{|c|c|c|}
\hline \multicolumn{3}{|c|}{ Figura 84: início do texto "O amor é surdo" } \\
\hline PASSADO & ANO(S) & ATRÁS (2) \\
\hline Tronco inclinado para trás, mas direcionado ao narratário \\
Olhar desviado do narratário \\
Sinais deslocados do centro do corpo do sinalizador, localizados à direita e para cima, região \\
onde foi sinalizado PASSADO
\end{tabular}

Pode-se dizer, então, que, no texto "O amor é surdo", o MR instaurado nesse enunciado inicial é anterior ao ME. A sequência de sinais PASSADO - ANO(S) - ATRÁS (2) indica a instauração de um sistema temporal enuncivo (portanto, ocorre uma debreagem enunciva). A partir desse marco temporal, todos os demais tempos da história são criados. Na figura 85, podemos ver a realização de um passado, concomitante a esse MR passado, na sinalização da ação de nascer. É o momento em que o narrador conta que uma mulher teve um bebê surdo.

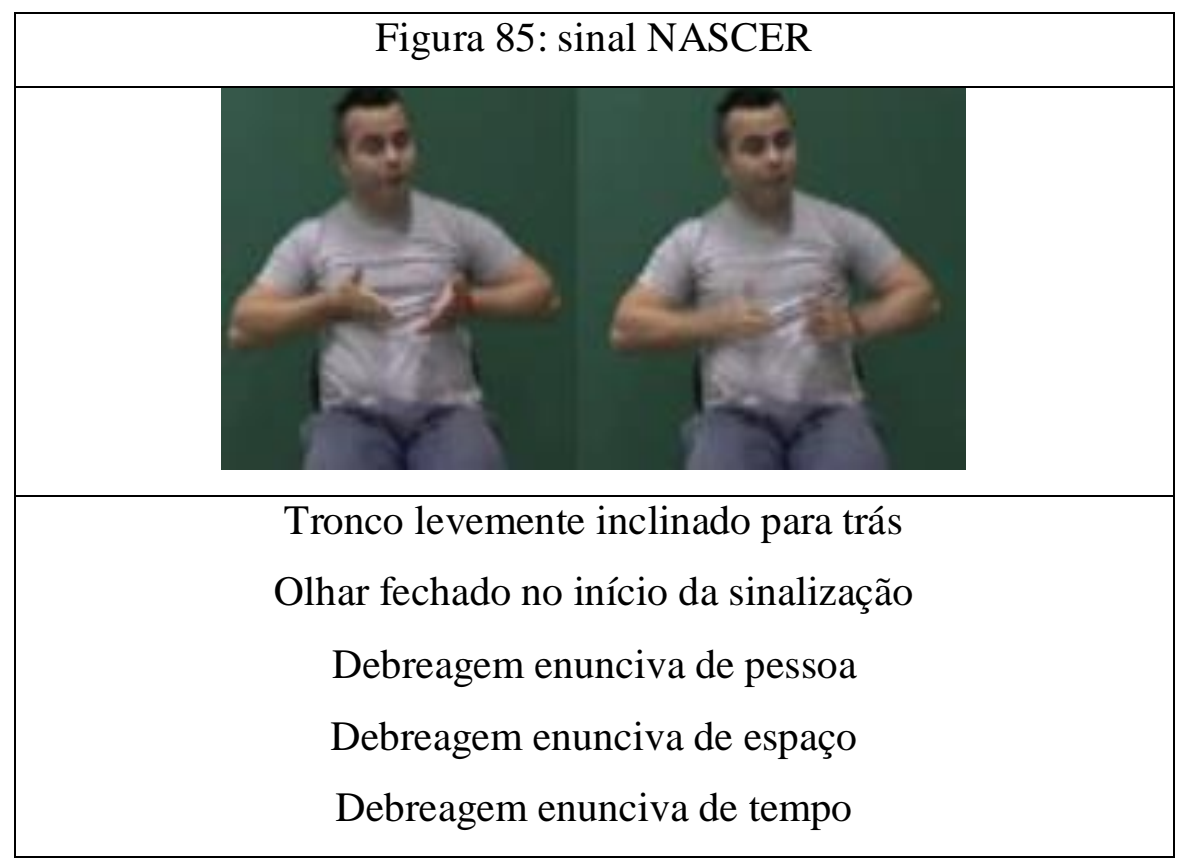


Percebe-se, na figura 85, a recorrência do movimento do corpo (tronco inclinado para trás) e da direção do olhar (olhos fechados e, portanto, desviados do narratário), o que reforça a ideia de que, para marcar o tempo do passado, ou seja, a não-concomitância com o momento da enunciação, é necessária toda essa gestualidade que marca o distanciamento entre o enunciador e o enunciatário. Não há uma narração em primeira pessoa, por exemplo, como foi notado em outros textos. Nesse caso, é possível entender que o olhar do narrador para o narratário não instaura a primeira pessoa no enunciado, mas instaura o narrador, deixando mais claro que o enunciado produzido é do nível do narrado (debreagem de primeiro grau) e não do interlocutor (debreagem de segundo grau).

Na figura 86, abaixo, temos outro exemplo, produzido por Neiva, que diz algo como "no passado, em 1822”. Esse início de enunciado pertence a um texto em que a narradora explica que a independência do Brasil foi declarada por Dom Pedro I, às margens do rio Ipiranga.

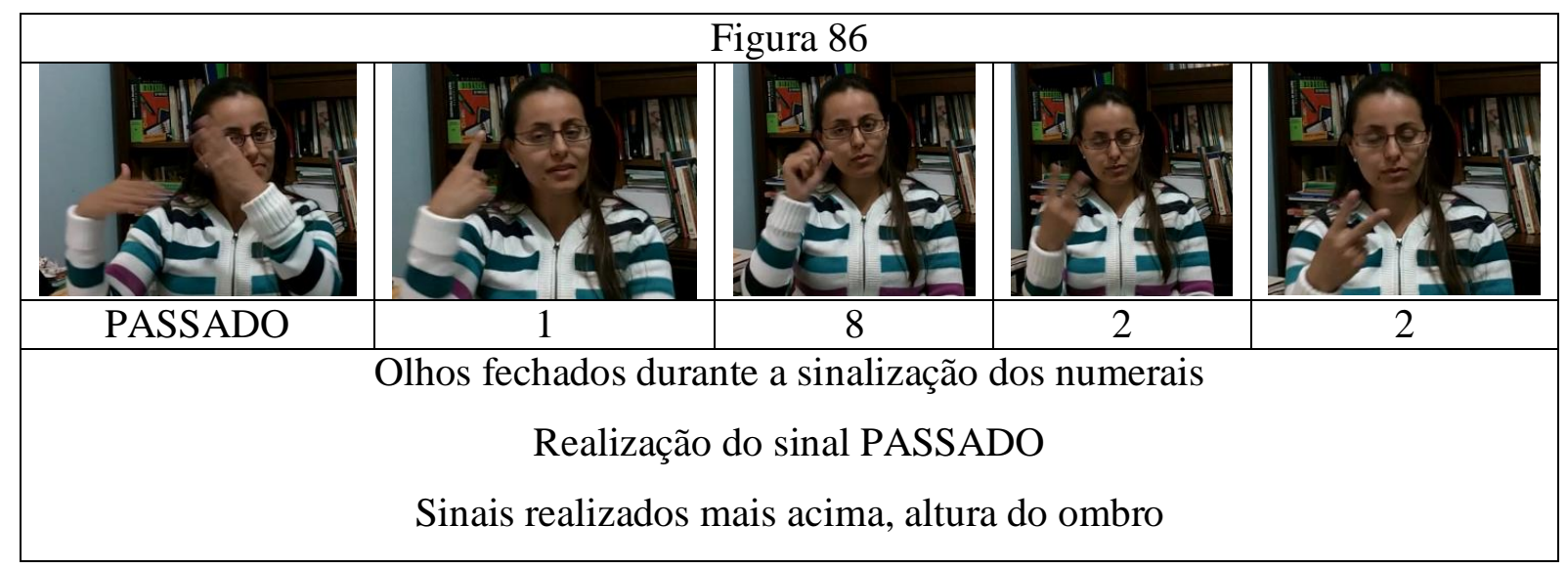

No texto de Neiva, é instaurado um MR passado, portanto, todo um sistema temporal enuncivo é criado. O item lexical passado e a realização dos numerais que indicam a data do acontecimento são marcas enuncivas que indicam um MA concomitante a um MR passado. Novamente, é possível observar uma gestualidade que parece marcar uma concordância com o tempo não concomitante ao ME que foi marcado no enunciado: olhos fechados, sinais realizados mais acima, próximos ao ombro, onde foi sinalizado o sinal PASSADO, e a realização de um item lexical que indica tempo enuncivo, PASSADO. Embora o corpo se desloque muito pouco, muito em função da própria articulação do item lexical que foi realizado no início, o tronco da sinalizadora sofre uma pequena inclinação para trás também, como já foi mostrado no capítulo 2.

As marcas de um passado do sistema enuncivo também podem ser observadas nos enunciados do texto "Minha Vida", em que a sinalizadora Neiva instaura um narrador em 
primeira pessoa e conta sua história, como já foi mostrado, projetando, nos enunciados iniciais, um MR que pertence a um sistema temporal enunciativo. Nessa história, o narrador também precisa, em um certo momento, narrar o que tinha lhe acontecido antes de se casar. Nesse instante, é instaurado um novo MR, a partir do qual os demais tempos se organizam. O MA, portanto, que aparecerá nessa parte da sinalização de Neiva é concomitante a um MR passado, um tempo enuncivo, que é instaurado no instante em que é produzido o sinal PASSADO no texto. Na figura 87, podemos observar esse momento da história.

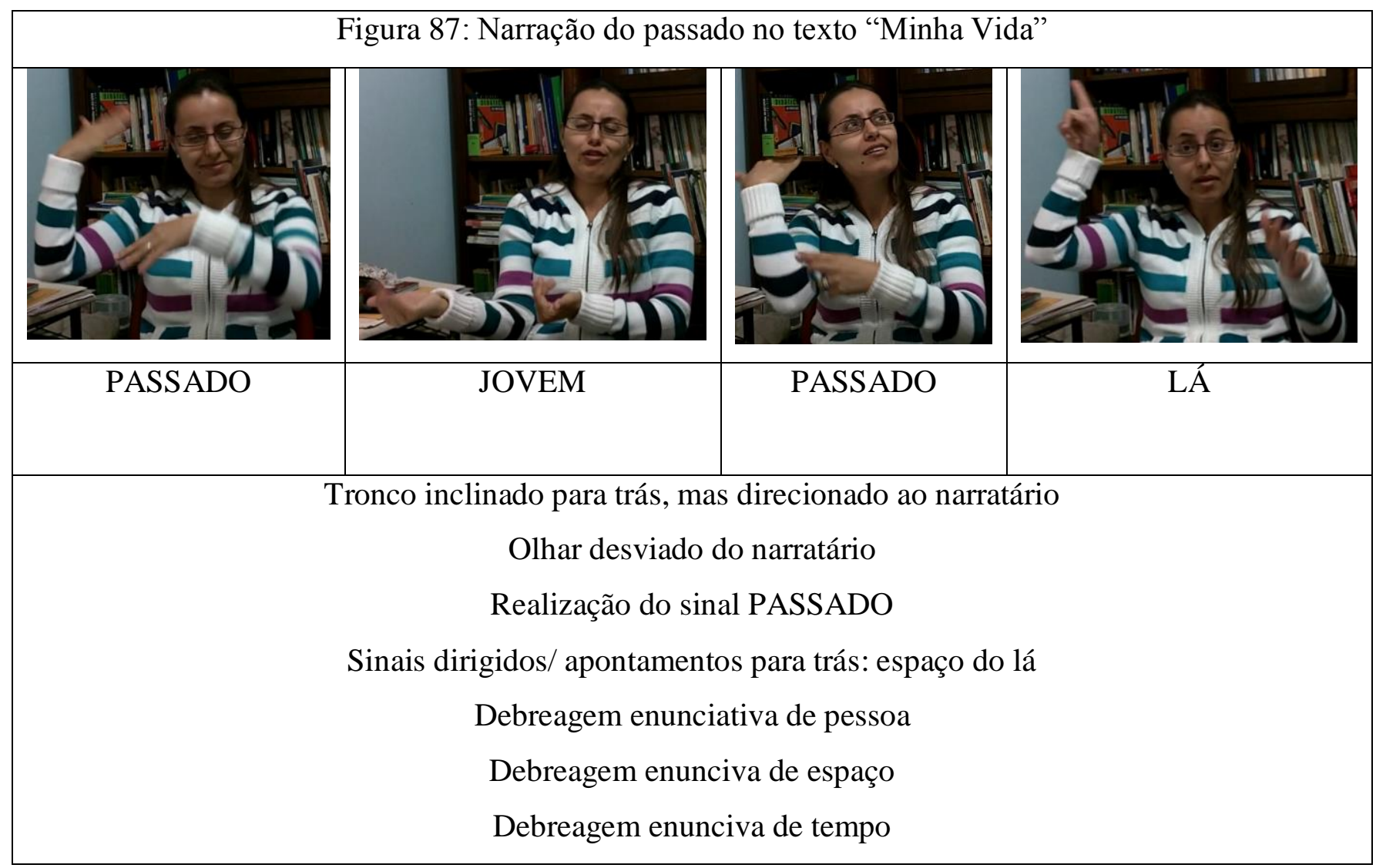

Na figura 87, é possível perceber que, como na narração do Cascão e da Marina, o tronco da sinalizadora está inclinado para trás, os olhos estão desviados do narratário (eles se fecham em alguns momentos). Diferentemente do que ocorre nas falas das personagens de "História do Gibi 1”, por exemplo, há também uma marcação lexical e manual desse passado, dessa anterioridade, pois é realizado o sinal PASSADO, o mesmo que marca o tempo enuncivo no texto "O amor é surdo". E, também, nota-se que os sinais, como JOVEM e LÁ, são realizados mais acima, à direita e distante do corpo da sinalizadora. Nos exemplos 85, 86 e 87, percebemos o quanto a marcação de um espaço enuncivo acontece simultaneamente à uma marcação enunciva de tempo. 
No corpus, há ainda outro texto em que o tempo enuncivo é instaurado, a partir do mesmo item lexical PASSADO e da gestualidade que ajuda a marcar a não concomitância dos eventos. Trata-se do texto "Metáfora - O escorpião e a tartaruga", em que há, como já foi dito, três histórias diferentes, mas parecidas em relação à marcação do tempo enuncivo. Há marcas explícitas da passagem de uma para a outra, que, inclusive, organizam-nas temporalmente. $\mathrm{Na}$ primeira, Rimar comenta que seu pai, um dia, ao ler um livro, se deparou com a palavra "instinto", que ele não conhecia. Ele, então, perguntou a sua filha ouvinte se ela sabia o que isso significava. A filha tentou explicar, mas sem sucesso. A transição do nível da narração para esse primeiro enunciado do nível do narrado é feita quando o narrador realiza os sinais de O QUE e ACONTECER, e, com as mãos, representa metaforicamente um período de tempo, que seria esse da primeira história que ele vai contar. Essa sinalização anuncia que o que vem a seguir é algo que aconteceu em outro momento, não concomitante ao ME.

Na figura 88, podemos ver o momento em que é instaurado no texto de Rimar o tempo enuncivo do então, por meio dos itens lexicais O QUE, ACONTECER e PASSADO, e o momentos em que é instaurada a pessoa, ele, o pai de Rimar.

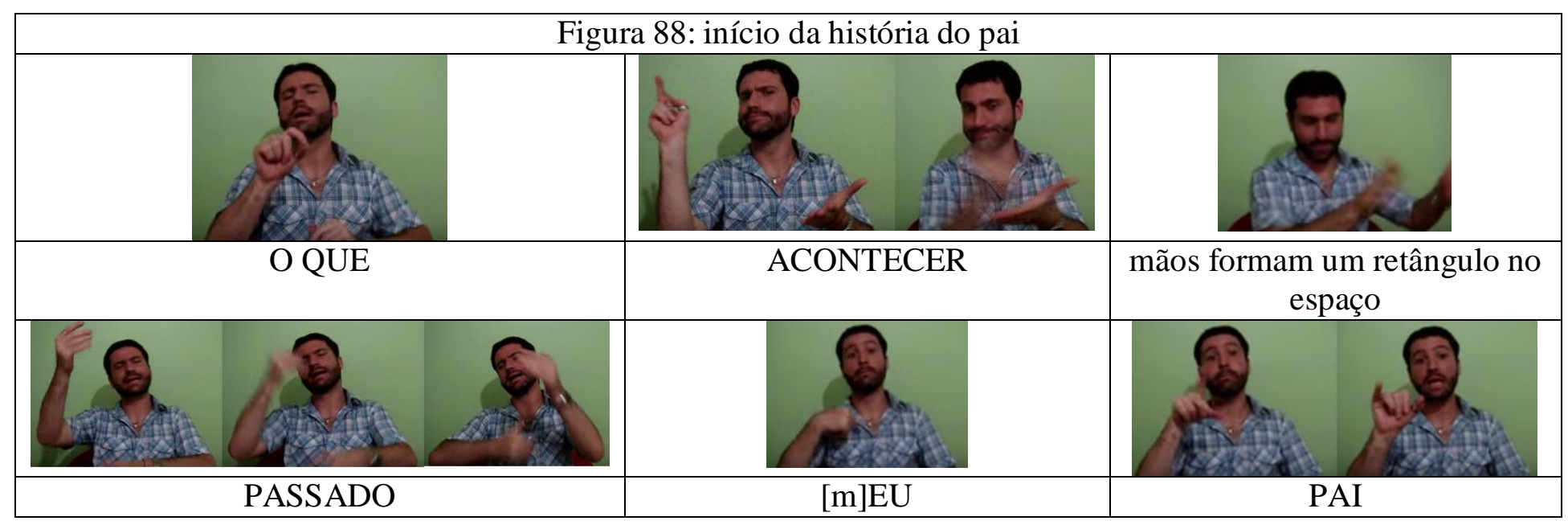

É possível observar na figura 89, a seguir, que, durante a sinalização do sinal PASSADO, o tronco do sinalizado se inclina para trás, os olhos se fecham, desviando de seu narratário, o que marca, como em "O amor é surdo", um tempo passado, dentro de um sistema temporal enuncivo: o que é contado não se encontra no mesmo instante da enunciação. 


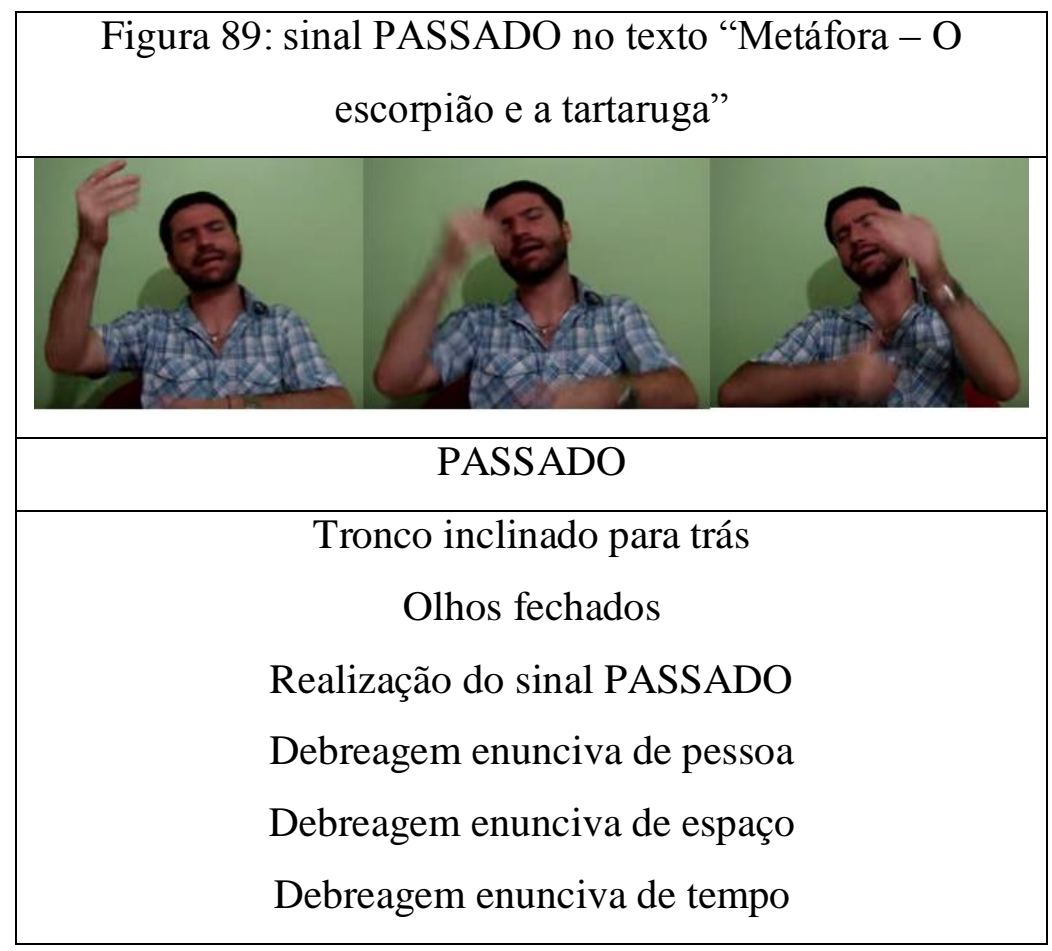

Em seguida a esse marcador temporal, Rimar introduz a primeira personagem dessa pequena primeira narrativa: o pai dele, que já aparece demonstrado, lendo um texto, na última imagem da figura 90, abaixo. Há, portanto, além da debreagem temporal enunciva, uma debreagem enunciva de pessoa nessa parte do texto.

\begin{tabular}{|c|c|c|}
\hline \multicolumn{3}{|c|}{ Figura 90: apresentação da personagem pai } \\
\hline EU & PAI & PRO \\
\hline EO & & \\
\hline (sinal do pai $]$ & PRO & \\
\hline
\end{tabular}

Depois de introduzir a personagem do pai, o narrador conta o diálogo que ele e a filha tiveram. Nesse momento, como em todo discurso direto, há um simulação da enunciação. No entanto, os enunciados que compõem as falas das personagens não se encontram no presente. Nessa sinalização, como nos diálogos do texto "História do Gibi 1", as personagens aparecem 
conversando, como é possível ver na figura 91, a seguir, quando o narrador, demonstrando o pai, dirige-se à filha, que será demostrada, no texto, do lado oposto.

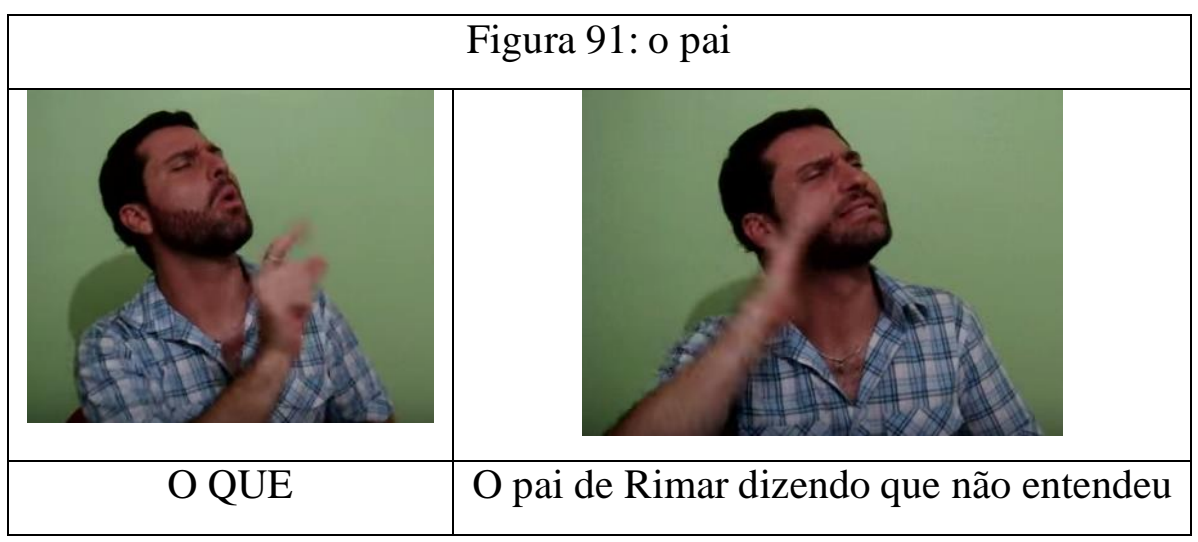

Embora o narrador demonstre a ação de cada uma das personagens, o que se nota nessas sinalizações, é que as falas das personagens são substituídas por enunciados do narrador. É curioso observar que, nesses momentos, toda uma gestualidade de passado aparece em cena: tronco para trás, olhos fechados, o que parece marcar uma não concomitância entre o tempo desses acontecimentos narrados e o ME, ou seja, nesses enunciados da figura 92, é instaurado um tempo enuncivo, concomitante ao MR passado que foi instaurado no início da história do pai, com o uso do sinal PASSADO.

\begin{tabular}{|c|c|}
\hline \multicolumn{3}{|c|}{ Figura 92: Interação entre o pai e a filha } \\
\hline O pai & A filha \\
\hline PERGUNTAR & EXPLICAR \\
\hline
\end{tabular}

$\mathrm{Na}$ segunda história contada por Rimar, depois de contar que a irmã ouvinte não conseguiu explicar para o pai a palavra "instinto", e de o pai teve que perguntar a outra pessoa, que também não soube explicar direito. O narrador, então, conta que, um dia, sua irmã estava no trabalho e um homem começou a paquerá-la e, então, lhe contou uma fábula. Para introduzir esse evento da irmã e do homem, o sinalizador realiza os sinais ESPERAR e IRMÃ, e, novamente, com as mãos formando um retângulo que corresponde ao período dessa história, o narrador faz 
um gesto, "empurrando" essa segunda história para sua direita, ordenando-a como um segundo momento, como mostra a figura 93, a seguir, marcando, assim, que o que vai contar não ocorreu no mesmo momento em que a interação do pai e da filha, nem no momento instaurado no início do vídeo, na apresentação do assunto do texto. O MR introduzido, nesse instante, é passado e a partir dele um sistema temporal enuncivo é novamente instaurado no texto.

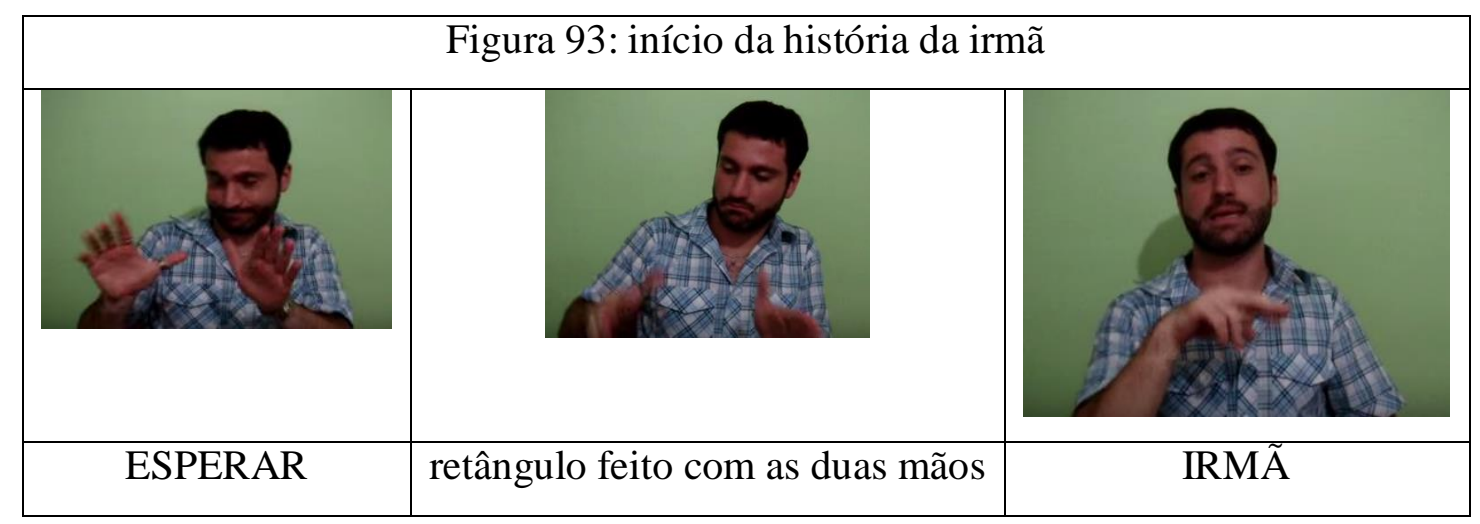

Os dois tempos enuncivos distintos, em que ocorreu cada uma das histórias contadas por Rimar nesse início do texto "Metáfora - O escorpião e a tartaruga", ficam organizados de forma clara no espaço. Do lado esquerdo foi colocado o primeiro caso contado, do pai e da filha, o mais antigo, e, do lado esquerdo, o que veio depois, o da irmã com o homem.

A terceira história que compõem o texto de Rimar é a contada pelo homem que tinha paquerado a irmã de Rimar. Ele assume o papel de narrador e a sinalização passa a ser sobre o escorpião e a tartaruga. A transição entre o homem, personagem, interagindo com a irmã de Rimar, para narrador da fábula é a mesma que as anteriores. Novamente é realizado o sinal ACONTECER. Em seguida, com o corpo voltado para o narratário, o sinalizador faz o sinal de ÁRVORE e começa a construir o cenário da nova história. Nessa sinalização, há, portanto, uma gestualidade que instaura o narrador, não de primeira pessoa, mas de terceira pessoa (não há interação, por exemplo, entre narrador e narratário nesse momento do texto), e ocorre uma debreagem enunciva de espaço. O sinal ACONTECER, como havia acontecido antes, introduz um tempo do então. Na figura 94, abaixo, é possível ver como essa sinalização ocorre no início da terceira história de Rimar, que é a história do escorpião e da tartaruga. 


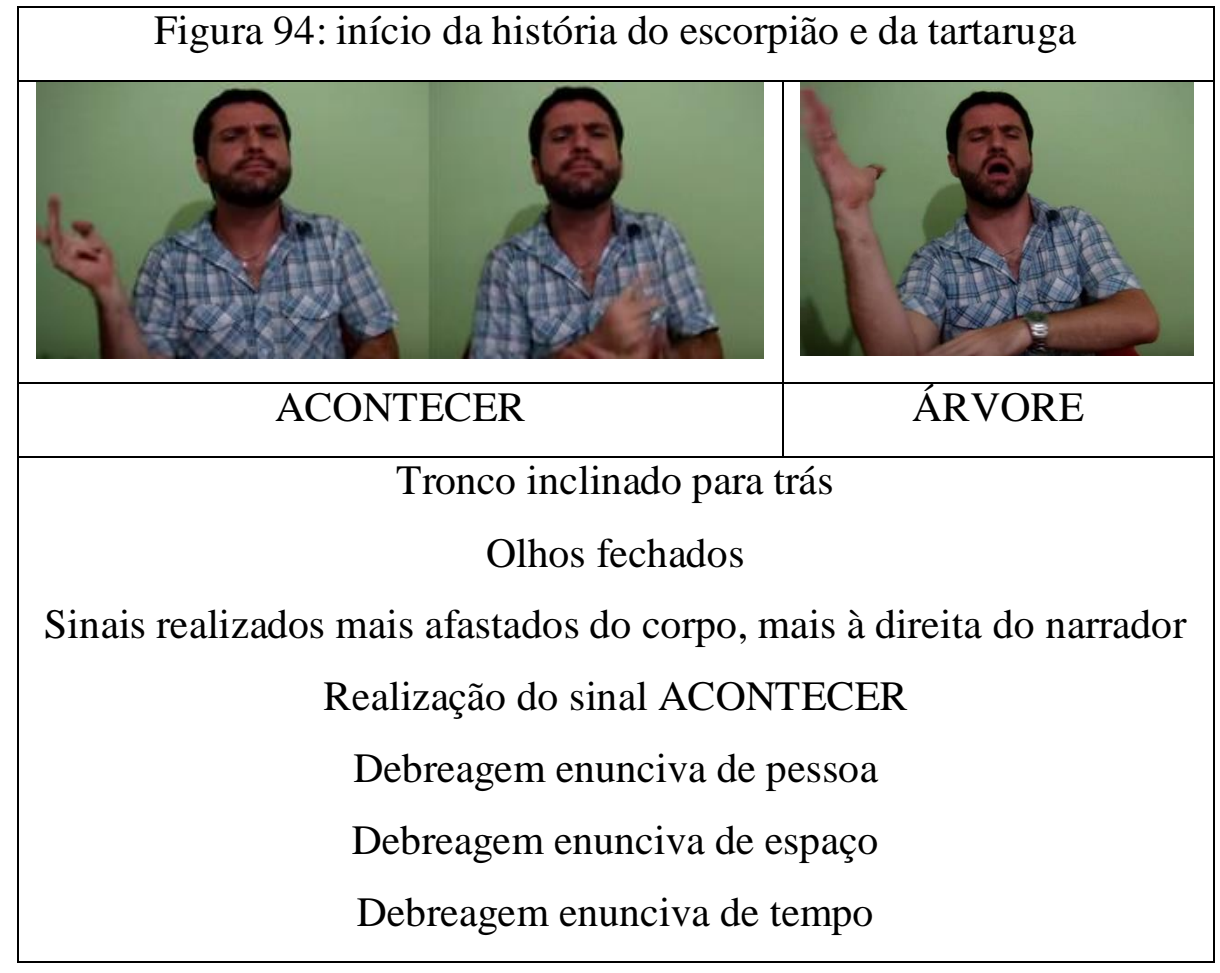

Na figura 94, acima, podemos notar que o corpo do sinalizador está inclinado para trás e o olhar muda, principalmente no momento em que o sinal ÁRVORE é sinalizado no texto. Os olhos do narrador se fecham, o que parece indicar terceira pessoa, um espaço do lá e uma nãoconcomitância do tempo do MA do que será contado com o presente. Nesse momento da história, além da debreagem enunciva de pessoa, também há uma debreagem enunciva de espaço e de tempo.

$\mathrm{Na}$ análise sobre os tempos enuncivos, em especial aqueles que se organizam a partir de um MR passado, foi possível identificar uma diferença entre um passado mais próximo e um passado mais distante. Na literatura, essa diferença é apontada pela localização do corpo no espaço. Se o corpo se inclina bastante para trás, há uma indicação de passado mais distante; se se inclina menos, um passado mais próximo. Nos dados analisados nesta pesquisa, foi identificada outra diferença na sinalização de um ou de outro.

Em outro texto de Neiva, já mostrado nesta seção, a sinalizadora realiza o sinal PASSADO de forma acelerada, com as mãos fazendo movimentos mais curtos e mais próximos à cabeça, no lado direito do corpo, como mostra a figura 95. 


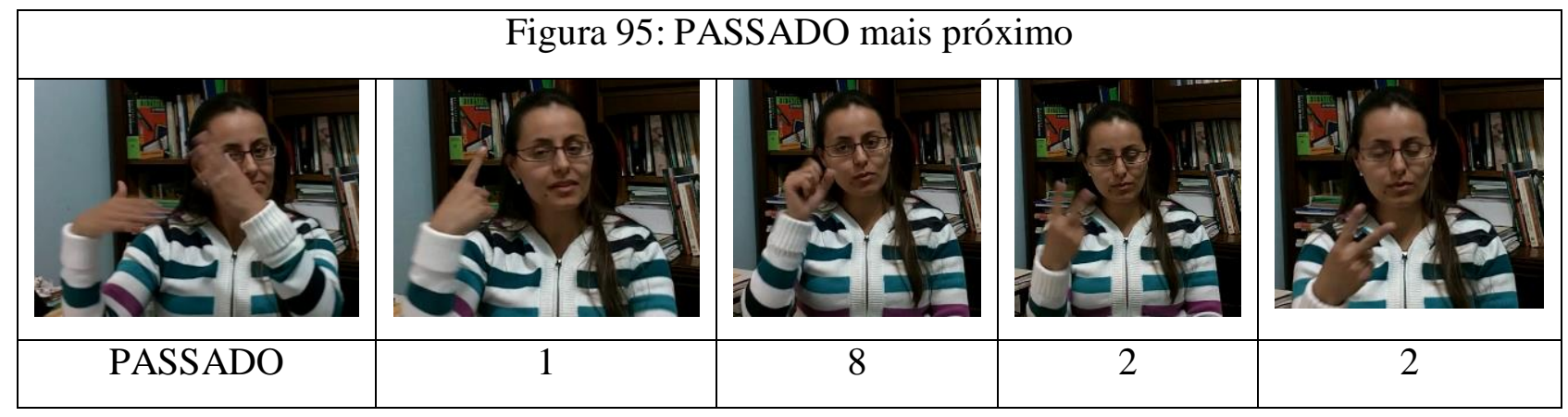

Em "Metáfora - O escorpião e a tartaruga", o mesmo sinal PASSADO é realizado com os braços mais abertos, as mãos se movendo de forma mais longa e lenta, e o corpo do sinalizador se inclina mais para trás, como é possível ver novamente na figura 96.

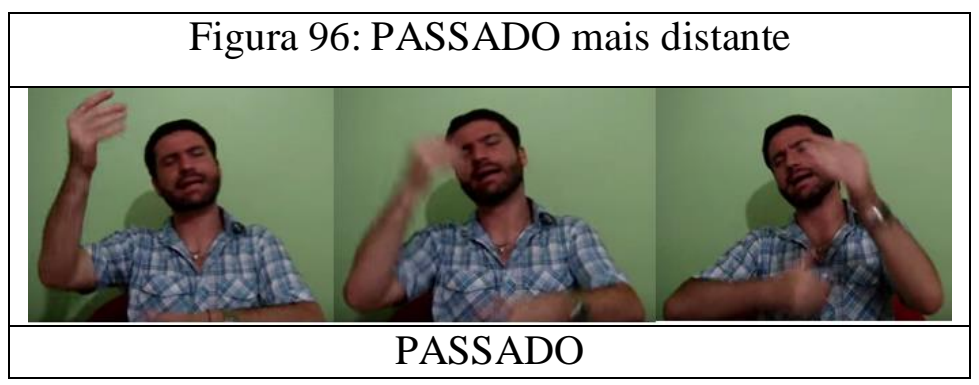

Partindo de uma proposta de Zilberberg (2015) da relação entre as categorias do plano da expressão da pintura relacionadas com as categorias de ritmo e temporalidade do plano do conteúdo, esquematizadas na figura 97 do autor, abaixo, talvez possamos pensar que a aceleração do movimento do sinal PASSADO possa estar associada à ideia de um passado próximo, ligado à ideia de um sobrevir, e a desaceleração do movimento, ligada ao pervir, um passado distante.

\begin{tabular}{|c|c|c|c|c|c|}
\hline \multicolumn{5}{|c|}{ Figura 97 } \\
\hline \multicolumn{2}{|c|}{$\begin{array}{l}\text { plan de } \\
\text { l'expression }\end{array}$} & à-plat & étalé & enlevé & sabré \\
& & $s_{1}$ & $s_{2}$ & $s_{3}$ & $s_{4}$ \\
\hline \multirow{2}{*}{$\begin{array}{l}\text { plan du } \\
\text { contenu }\end{array}$} & tempo $\rightarrow$ & ralentissement & \multicolumn{2}{c|}{ accélération } \\
\cline { 2 - 6 } & temporalité $\rightarrow$ & temporalité allongeante & temporalité abrégeante \\
\hline
\end{tabular}


Embora, no texto de Neiva, o momento do acontecimento (1822) seja bem anterior ao momento em que ela enuncia (2011), a sinalizadora parece ter usado uma forma do sinal PASSADO que se refere a um tempo mais próximo, talvez porque ela tenha usado também os numerais que indicam o ano do evento para instaurar esse tempo enuncivo. É possível, assim, levantar uma hipótese de que o sinal PASSADO realizado por Neiva seja o da forma do passado próximo, mais pontual, definido, enquanto, o sinal PASSADO, no texto de Rimar, remeta a um tempo passado indefinido e, portanto, mais distante e, daí, os gestos mais largos na realização do sinal (é como se para chegar a esse tempo fosse preciso voltar mais no passado). Nesses textos, os efeitos de sentido gerados por cada um desses passados também são diferentes. No texto de Neiva, há uma objetividade de tempo sendo criada. No texto de Rimar, a indeterminação da data passada reforça a ficcionalidade da história contada, que é a fábula do escorpião e a tartaruga. Esses casos representados nas figuras 95 e 96 podem sugerir que, além de tempo, o que esteja ocorrendo é uma aspectualização, que não foi tratada por esta tese.

Como a literatura vem apontando, o tempo passado parece de fato ser construído, no espaço de sinalização, mais direcionado para a parte que fica atrás do sinalizador (os próprios itens que indicam esse tempo, como o sinal PASSADO, são realizados com as mãos do sinalizador com a palma voltada para trás) ou deslocado do centro do corpo do sinalizador. Também se nota certa regularidade no movimento do tronco de quem sinaliza, para trás, durante a realização de sinais que indicam passado, e as mudanças no olhar, para marcar a nãoconcomitância com o presente, o que pode sugerir que a gestualidade corporal muitas vezes concorda com a marcação temporal feita por um sinal de tempo passado, por exemplo.

\subsubsection{2) Tempo futuro}

Nos textos do corpus, também há exemplos da instauração de tempos enuncivos que se organizam a partir do marco temporal futuro. Há, como no caso da não-concomitância do passado, mostrada anteriormente, itens lexicais que marcam o tempo do então, que manifestam uma debreagem temporal enunciva, e também uma gestualidade que acompanha a realização desses sinais que também podem indicar a construção de um espaço do lá e uma debreagem enunciva de pessoa. O tempo, nos exemplos a seguir, é interpretado como não concomitante ao ME.

No trecho final do texto "História do Gibi 1", temos um exemplo de um MA concomitante ao MR futuro instaurado nesse discurso. No trecho em destaque, na figura 98, há a 
realização do sinal IMAGINAR. Novamente, são notadas marcas gestuais que indicam que o tempo não é o do agora. É possível observar as imagens do momento em que ocorre a sinalização de um pensamento da personagem Cebolinha e, nesse instante da história, o narrador diz que Cebolinha imagina que vai pegar o coelhinho da Mônica. Mas, diante das dificuldades, a personagem desiste e não realiza essa ação. Há, portanto, aí, uma pequena antecipação do que poderia acontecer, mas que não acontece efetivamente na história.

\begin{tabular}{|l|l|l|}
\hline \multicolumn{3}{|c|}{ Figura 98: Cebolinha encontra o coelhinho da Mônica } \\
\hline
\end{tabular}

No trecho em que o Cebolinha encontra o Sansão, ele não interage com o coelhinho, mas consigo mesmo. A impressão é a de que estamos "lendo" o pensamento que ele teve, ao perceber a dificuldade que ele enfrentaria, se tentasse pegar o coelhinho. Ele diz ou pensa que, se pegar o coelhinho, pode ter problemas com a Mônica. Essa fala ou pensamento do Cebolinha pode ser considerado um exemplo de uso do futuro, ou um tempo que não é concomitante ao presente. $\mathrm{O}$ sinal IMAGINAR instaura um novo tempo dos acontecimentos, que seria posterior ao tempo em que o Cebolinha encontra o coelhinho. Nesse momento, o sinalizador inclina seu tronco para frente, o olhar está desviado do narratário e se volta para o local onde está o coelhinho. Os sinais realizados nesse momento são localizados à frente e distante de seu corpo. Na figura 99, podemos notar essa sinalização: 


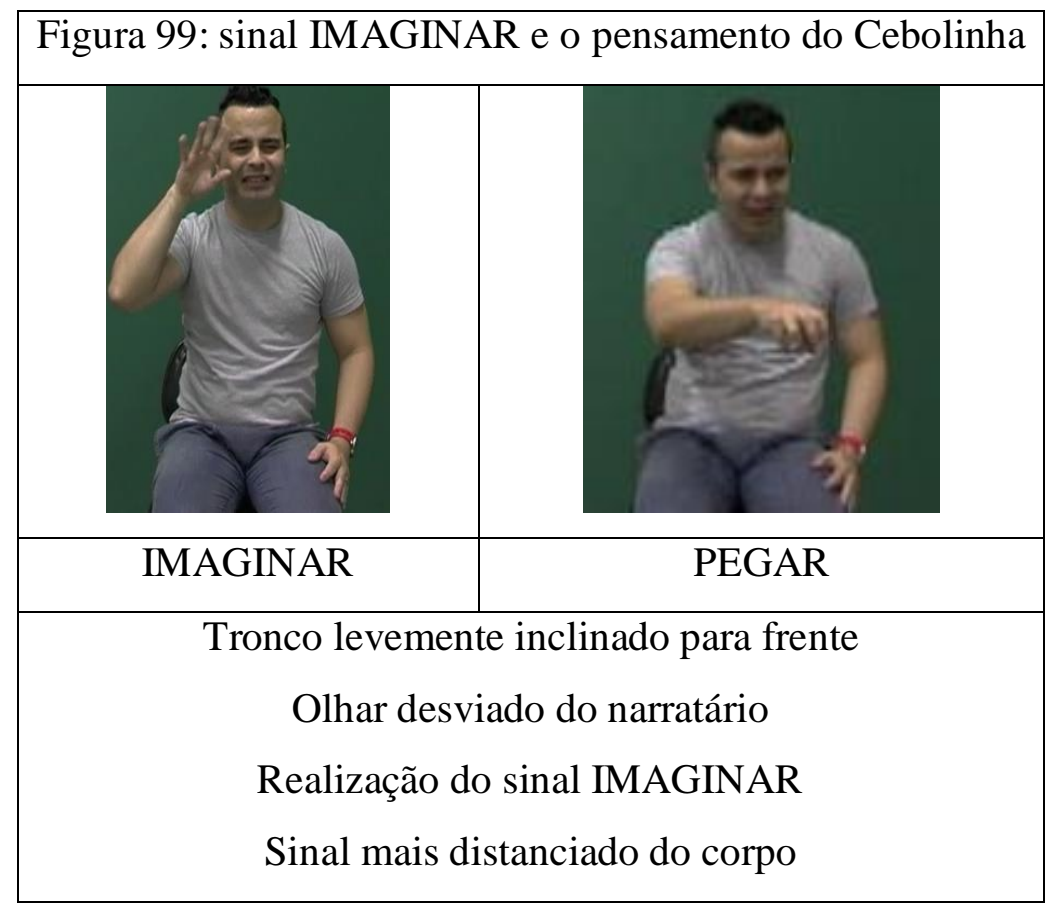

Nessa sinalização, na figura 99, o sinal IMAGINAR parece ser uma âncora temporal desse momento da história e reforça a ideia de um tempo enuncivo. As outras marcas também reforçam a ideia de futuro, como já observado na literatura. No texto "Sonhos", de Neiva, esse mesmo sinal é novamente usado, juntamente com o sinal FUTURO e IMAGINAR (2) ${ }^{114}$, que é realizado com as duas mãos, com movimento duplicado.

Na figura 100, abaixo, podemos perceber a sinalização de um momento da história em que uma das personagens imagina seu futuro e como estará. O tronco da sinalizadora se inclina para frente, os olhos desviam do narratário, as mãos se distanciam do corpo, enquanto os itens lexicais que indicam tempo acontecem.

\footnotetext{
${ }^{114} \mathrm{O}$ segundo sinal de IMAGINAR (2) é feito com as duas mãos, diferente do primeiro IMAGINAR e do que aparece em Capovilla \& Raphael (2001). Seguindo Klima \& Bellugi (1979), Xavier (2014) mostra que, em libras, assim como na ASL, a duplicação das mãos na realização de sinais como APRENDER, IMAGINAR e FALAR pode estar ligada à expressão de aspecto continuativo (progressivo) e aspecto interativo na língua. $\mathrm{O}$ autor também aponta que, na literatura de língua de sinais, a duplicação das mãos pode estar relacionada também na distinção entre o que seria em libras o pretérito imperfeito e o pretérito perfeito. Para um estudo mais detalhado sobre o parâmetro do número de mãos na realização dos sinais da libras, ver Xavier \& Barbosa (2013) e Xavier (2014).
} 


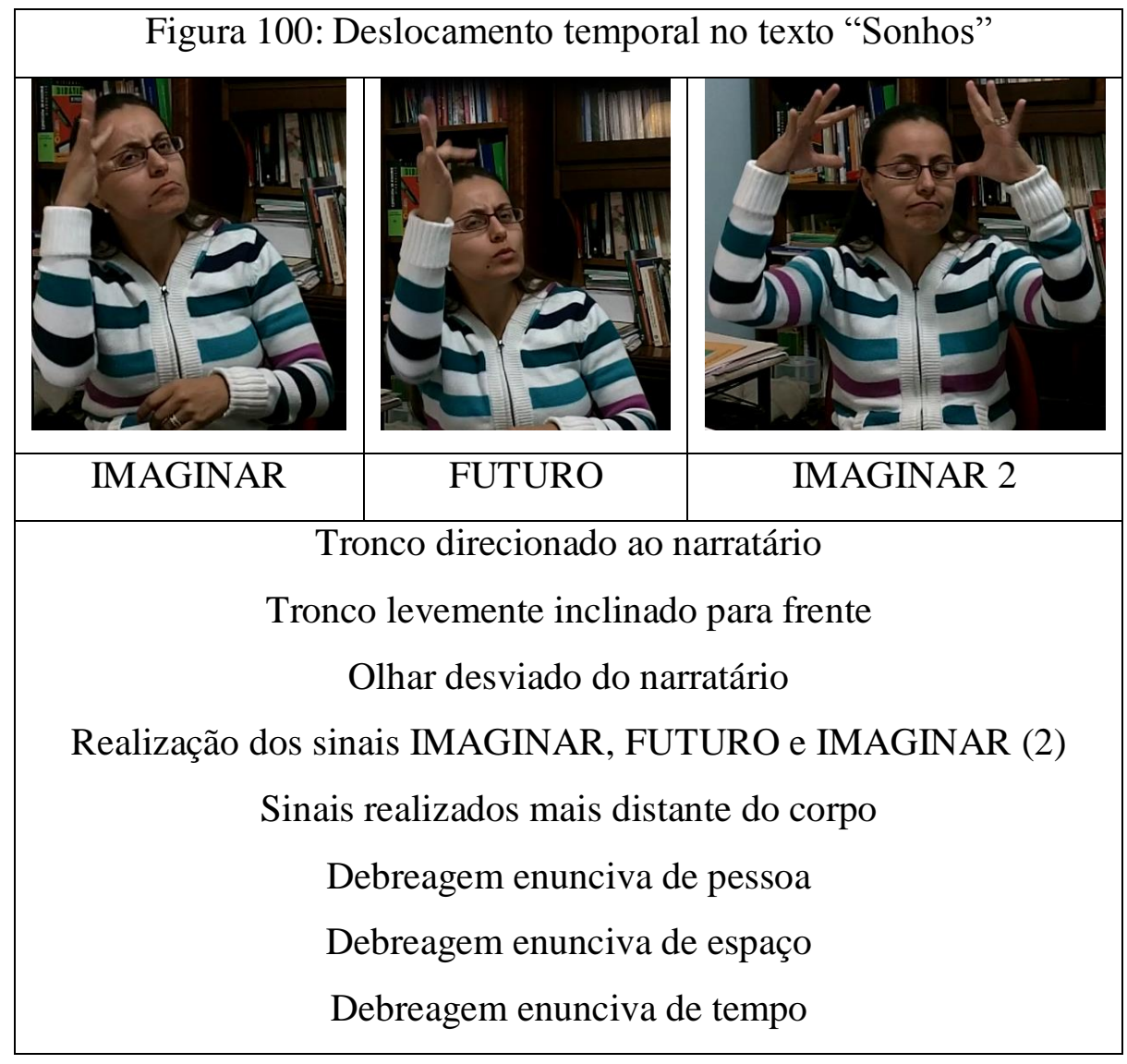

Em mais dois textos do corpus, sinalizados por Neiva, o sinal IMAGINAR, acompanhado de outros elementos gestuais, como a inclinação do tronco, o olhar desviado do narratário, sem foco, ou fechado, as mãos localizadas mais à frente do corpo, durante a sinalização, parece instaurar um tempo futuro organizado a partir, então, de um MR futuro. No texto "Imaginação", na figura 101, há um momento em que a narradora conta que a personagem imagina toda uma transformação em sua casa, em seu marido. Isso é mostrado como um MA não concomitante ao ME. É possível perceber quando o olhar da narradora deixa de se dirigir ao narratário e olha para um lugar do espaço em que tinha sido demonstrado o marido e a sala, e, ao realizar o sinal IMAGINAR, Neiva fecha seus olhos, marcando a não-concomitância do que será narrado com o que, até então, estava sendo contado no texto. 


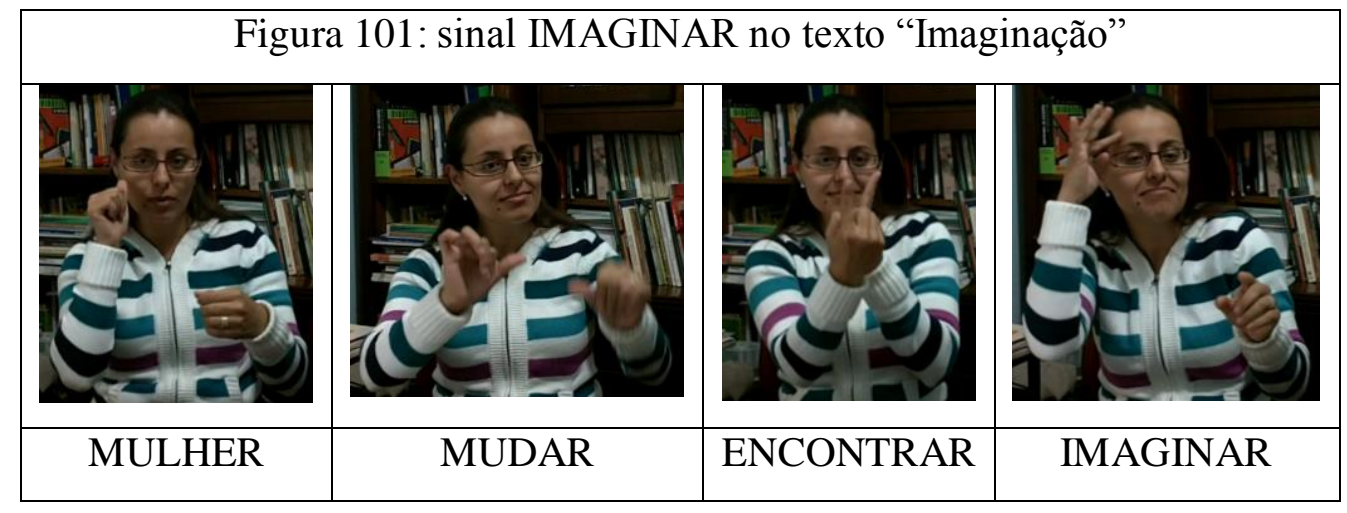

No texto "Explicação", há dois momentos em que aparece o sinal IMAGINAR, instaurando um MR futuro. Na figura 102, podemos ver, novamente, o sinal, mas, antes, também o sinal SE em libras, que parece ajudar na realização dos tempos não concomitantes à enunciação. A gestualidade do corpo, já mencionada, também se verifica na sinalização abaixo.

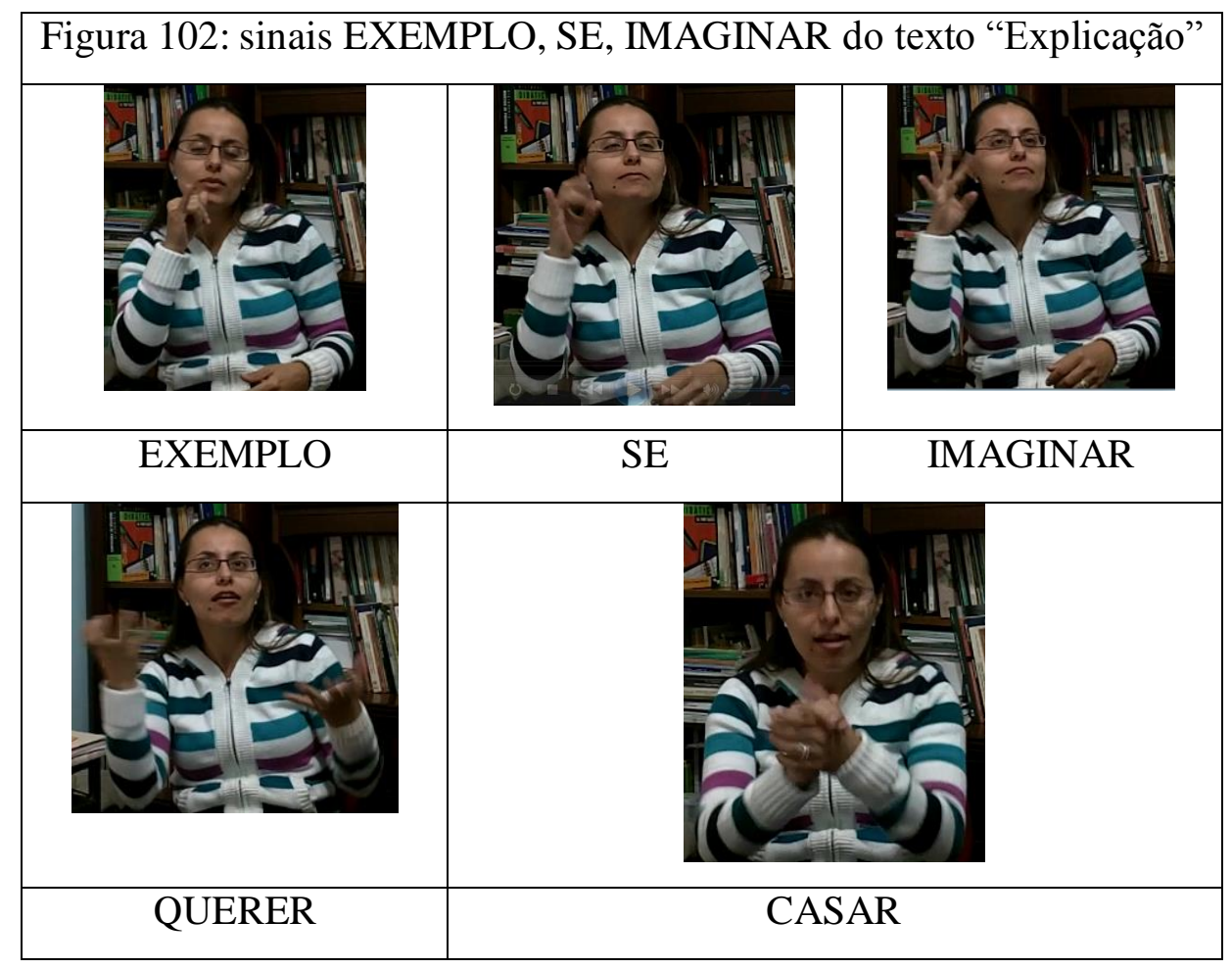

No mesmo texto, "Explicação", a narradora faz, em outro enunciado, os sinais SE e IMAGINAR, e, de novo, seu corpo se inclina para frente, as mãos sinalizam mais distante do corpo e os olhos desviam do narratário, como é possível observar na figura 103. 


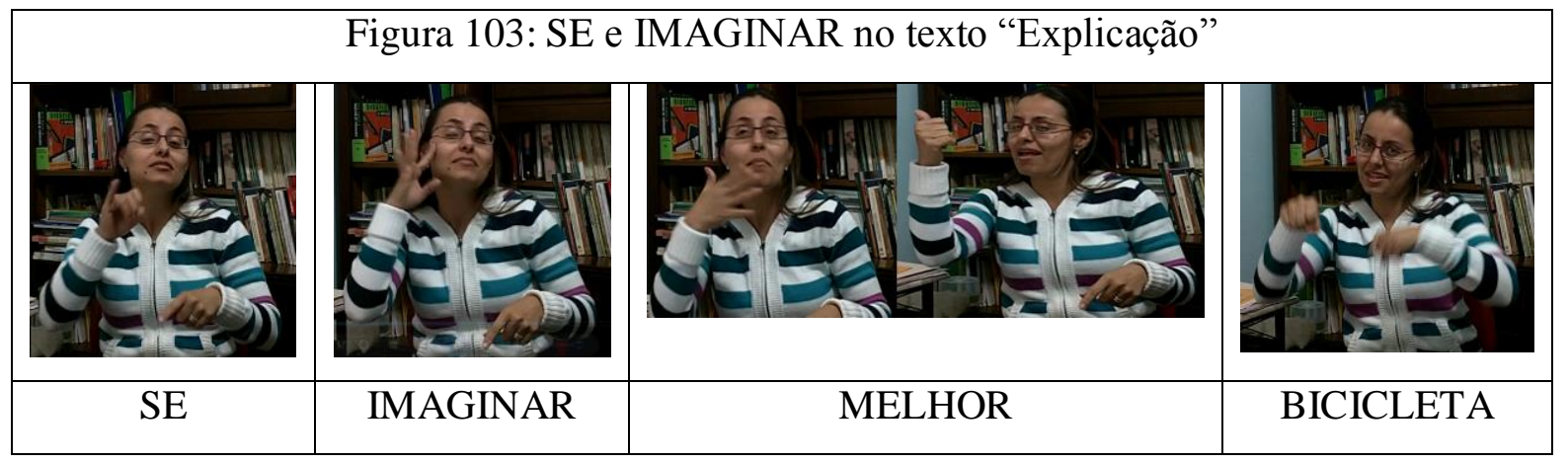

No texto "Sonho com um carro novo", sinalizado por Regiane, também se nota a instauração de um tempo futuro. Nesse discurso, no entanto, só há a realização do item lexical FUTURO. O corpo da sinalizadora não se inclina para frente, mas sim, para trás, posição criada para demonstrar a personagem que, nesse momento, fala no discurso, mas é possível verificar como as mãos se localizam mais distante do corpo e os sinais projetados para frente. Além disso, é possível perceber, em alguns momentos, que os olhos da sinalizadora se fecham. Na figura 104, é possível notar o instante em que a personagem do texto se dirige a um colega de trabalho e pergunta no que ele trabalhará no futuro, daqui a cinco anos.

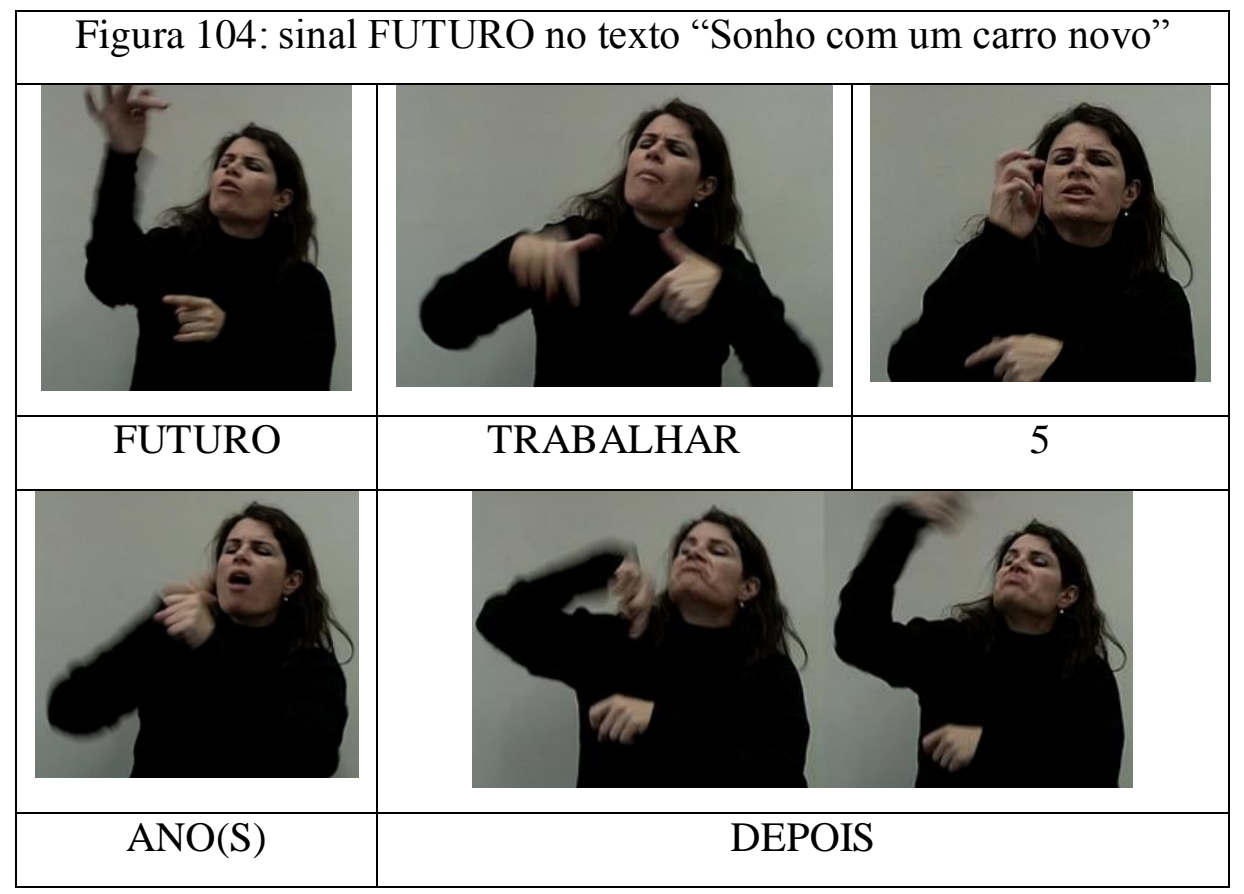

Alguns dos sinais realizados por Regiane, na figura acima, são articulados de modo a se afastar do corpo e ser dirigidos para frente, como o próprio sinal FUTURO e o sinal DEPOIS, por exemplo. Mas alguns, como $\mathrm{ANO}(\mathrm{S})$, nessa sinalização, é realizado mais para cima, com um 
movimento das mãos para frente. Só depois de toda essa instauração do tempo é que o narrador começa a contar sobre o que pode acontecer com uma das personagens da história, o que ela imagina que acontecerá depois de cinco anos.

\section{2) As embreagens temporais em libras}

Além das debreagens enunciativas e enuncivas identificadas na seção anterior, também foi possível verificar a ocorrência de outro processo de instalar os tempos nos enunciados nos textos do corpus analisado nesta tese: as embreagens (homocategóricas e heterocategóricas). Como foi visto no capítulo1, na embreagem temporal, os termos de uma oposição temporal são neutralizados, e um tempo é usado no lugar do outro.

No texto "Explicação", há um dado em que aparece o sinal FUTURO, e, portanto, era de se esperar uma debreagem enunciva, com a instalação de um MR não concomitante ao ME, mas a oposição desse termo com o presente é neutralizada. Isso é verificado, no decorrer da sinalização, com o aparecimento de uma gestualidade corporal que não está de acordo com a marcação de futuro, como tinham mostrado os exemplos anteriores de tempos enuncivos organizados a partir do MR futuro.

Na figura 105, a seguir, é possível ver que, durante a realização de FUTURO, a cabeça da sinalizadora se inclina para frente, mas seu tronco se mantém na posição neutra. Em seguida, realiza o sinal PODER, sem qualquer alteração no tronco. As mãos são localizadas em frente ao corpo, estão um pouco mais afastadas do corpo, mas a grande diferença, ainda não notada nos dados já analisados até esta seção. É que o olhar da sinalizadora não muda, em toda essa sinalização. Ele se mantém o tempo todo direcionado ao narratário, como se estivesse marcando a

primeira pessoa e, portanto, fosse uma gestualidade enunciativa. E, de fato, parece ser isso mesmo o que acontece. Nota-se que a sinalizadora, com a mão esquerda, na primeira foto, realiza um apontamento direcionado ao narratário (o que caracteriza uma debreagem enunciativa de pessoa), enquanto realiza o sinal FUTURO. 


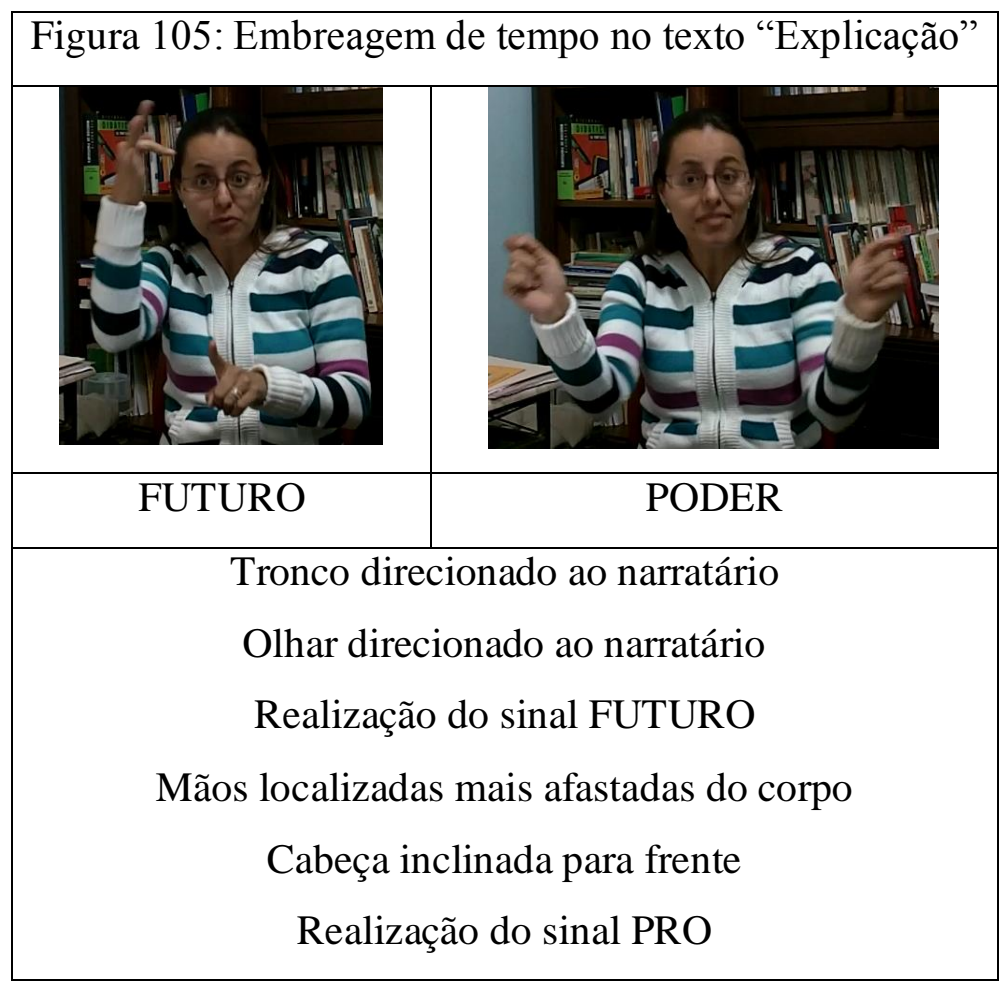

A gestualidade do olhar que indica a instauração de um $e u$ e um $t u$ é a mesma que, em alguns textos do corpus, esteve envolvida na marcação de presente. Parece, portanto, que, apesar do sinal FUTURO, o enunciado é realizado de forma parecida a enunciados em que o sistema temporal instaurado é enunciativo. Nesse caso, o que se teria é um tempo presente sendo usado com valor de futuro, e o futuro marcado pelo item lexical ter sido neutralizado pela gestualidade do olhar que indica pessoa, constrói um espaço enunciativo, e, portanto, pode indicar presente. Pode se tratar, assim, de uma embreagem de tempo enunciativa. O uso do presente no lugar do futuro aproxima o fato narrado futuro, dando mais certeza de sua existência. Nesse texto, Neiva estava explicando uma propaganda de TV e dizendo a seu narratário que o texto do anúncio convence "você" a comprar o carro, porque pode, no futuro, querer casar, formar uma família e precisar de um automóvel grande, seguro, etc. É uma forma de presentificar, portanto, o MA, tornando-o mais real, ao criar essa concomitância proposital com o ME.

Neste trabalho, o interesse recai sobre as embreagens heterocategóricas que são aquelas que são responsáveis pela temporalização nos textos em libras. 


\subsection{1) Embreagem heterocategórica e a marcação do tempo em libras}

Em alguns textos do corpus, também foi possível observar outro tipo de embreagem ocorrendo: a embreagem heterocategórica. Como já foi explicado anteriormente, no capítulo 1, essa embreagem ocorre quando há a neutralização de termos de categorias diferentes, e uma é usada pela outra (espaço pelo tempo, tempo pelo espaço, etc.). Nesta análise, considerou-se que esse tipo de mecanismo enunciativo ocorreu em todos os textos selecionados. Nas histórias em que há uma marcação lexical explícita de tempo, podem também ocorrer outros elementos, que marcam espaço (enuncivo ou enunciativo), que entram em concordância com a marcação temporal realizada. Nos textos em que não há sinais que indicam tempo, pode haver três tipos de embreagem heterocategórica: (i) há marcas de pessoa e de espaço, que podem ajudar a criar o presente, o passado ou o futur; (ii) há marcas de espaço, que contribuem com a construção de um tempo enunciativo ou enuncivo, e (iii) há marcas de pessoa, espaço e tempo, neutralizadas, que constroem as relações temporais nas histórias.

A figura 106, abaixo, apresenta o início do primeiro enunciado do nível do narrado do texto "História do Gibi 1". Nele, é instaurado o ator do enunciado, Cebolinha (o narrador faz o sinal de CEBOLINHA, depois um PRO, ele, e um sinal que significa pessoa andando, ANDAR A PÉ (3)). Nesse instante, não há nenhuma marcação explícita de tempo.

\begin{tabular}{|l|l|}
\hline \multicolumn{3}{|c|}{ Figura 106: início do texto "História do Gibi 1" } \\
\hline CEBOLINHA & PRO \\
\hline \multicolumn{3}{|c|}{ Tronco direcionado para o narratário } \\
Olhar direcionados para o narratário \\
Realização do sinal CEBOLINHA, PRO e ANDAR A PÉ (3) \\
Debreagem enunciva de pessoa \\
Debreagem enunciva de espaço (3)
\end{tabular}


O que também pode ser notado na figura 106, acima, no entanto, é que há uma gestualidade nesse início de enunciado que, como no texto "Explicação", de Neiva, parece ser tipicamente enunciativa: tronco e olhar do sinalizador estão voltados para o narratário. Há uma movimentação do corpo mais para a direita, local onde o narrador instaura o ele e apresenta a personagem. Em seguida, o corpo volta a uma posição neutra, para, depois, realizar movimentos que demonstra a ação de Cebolinha andando. Na figura 107, abaixo, é possível perceber, por meio de uma sequência de fotos do vídeo, o momento da história em que o sinalizador é, ao mesmo tempo, narrador (ele narra os fatos) e a personagem Cebolinha, realizando a ação dela (o narrador demonstra os fatos ocorridos).

\begin{tabular}{|l|l|l|l|l|}
\hline \multicolumn{3}{|c|}{ Figura 107: sequência de cenas de narrador e personagem sincretizados } \\
\hline CEBOLINHA & & ANDAR A PE (3) & \\
\hline Cebolinha olha para a Magali] & & & & \\
\hline
\end{tabular}

É possível perceber, acima, que o sinalizador faz o sinal de pessoa em pé (com o dedo indicador apontado para cima), logo depois de ter sinalizado o sinal CEBOLINHA. Para demonstrar que o Cebolinha está caminhando, o narrador, ao mesmo tempo que diz que Cebolinha está andando, ele mexe os ombros, o tronco, e movimenta a cabeça, simulando a caminhada: é narrador ao mesmo tempo que é personagem. Na sequência, o narrador ainda faz o sinal VER (com a mão direita em V) e direciona esse sinal para sua esquerda, onde, mais adiante no texto, será representada a personagem Magali. Nesse momento, o narrador diz que Cebolinha vê a Magali, ao mesmo tempo em que faz os gestos do próprio Cebolinha, olhando para sua esquerda: tronco e cabeça virados para a esquerda. Em seguida, ele faz o sinal MAGALI e demonstra sua ação de chorar, enquanto sinaliza CHORO. Com essas mudanças nos gestos 
corporais, o sinalizador é, nesse instante do texto, o narrador e as personagens, o Cebolinha e a Magali.

Não há, como foi dito, nesse enunciado, o uso de um item lexical de tempo que pudesse explicitar o MR instaurado. Não tem como saber, então, ao certo, qual é o sistema temporal instaurado nesse nível da história. Como no caso dos dados de Sinte (2013), na "História do Gibi 1", temos uma situação em que que o tempo parece indefinido, por causa da ausência de uma marca manual de tempo explícita. Pode-se, no entanto, pensar que as pistas podem estar em outros elementos presentes nessa sinalização e observar a gestualidade que ocorre no início desse texto. Como também já foi apontado, há um conjunto de gestos corporais que podem, na língua, ser responsáveis pela marcação de espaço, de pessoa, e também indicar o tempo a partir do qual o discurso se organiza. Então, talvez, seja possível pensar que a pista para o tempo esteja na instauração das outras categorias enunciativas, por exemplo.

Diferentemente do que aconteceu no texto "Imaginação", de Neiva, analisado na seção anterior, não parece haver, nesse enunciado da "História do Gibi 1", uma neutralização de termos de uma oposição temporal, já que não houve a realização de nenhum item lexical que indicasse um tempo diferente do presente e que pudesse ser neutralizado. As marcas de tempo foram neutralizadas pelas categorias de pessoa e espaço, parecendo, por isso, estar indefinidas.

A intensa figuratividade presente em toda sinalização e essa característica da língua de realizar seus enunciados no espaço e explorar todos os recursos visuais possíveis para criar referências em seus textos podem fazer, também, com que, em alguns momentos, haja a geração de um efeito de sentido de presentificação dos fatos e, por isso, muitas vezes, se tem a sensação de algo no presente, acontecendo em frente aos nossos olhos, em um tempo concomitante ao ME, como se fosse um presente implícito ou até um presente gnômico.

Essa indefinição aparente do tempo talvez aconteça, justamente porque ele está neutralizado por categorias que não podem instalar um sistema temporal e, por isso, a possibilidade de um apagamento do valor de tempo, e uma maior presença das outras categorias enunciativas, bem marcadas no texto. Como a pessoa e o espaço instaurados no texto "História do Gibi 1" são enuncivos, é possível entender, entretanto, que o tempo instalado no enunciado também possa ser enuncivo. Isso seria coerente com o efeito de sentido que o texto também gera de virtualidade e distanciamento da realidade. Sabemos de que se trata de uma história ficcional logo de início.

No texto "Imaginação", sinalizado por Neiva, também é possível verificar a mesma possibilidade de ocorrência desse tipo de embreagem. Não há também, nesse texto, como se pode 
ver pela figura 108, abaixo, uma marcação de tempo explícita. Há, visivelmente, a marcação de pessoa e de um espaço enuncivos, logo no início do enunciado. A gestualidade parece enunciativa de novo: tronco na posição neutra, olhar dirigido ao narratário, sinais produzidos próximos ao corpo da sinalizadora.

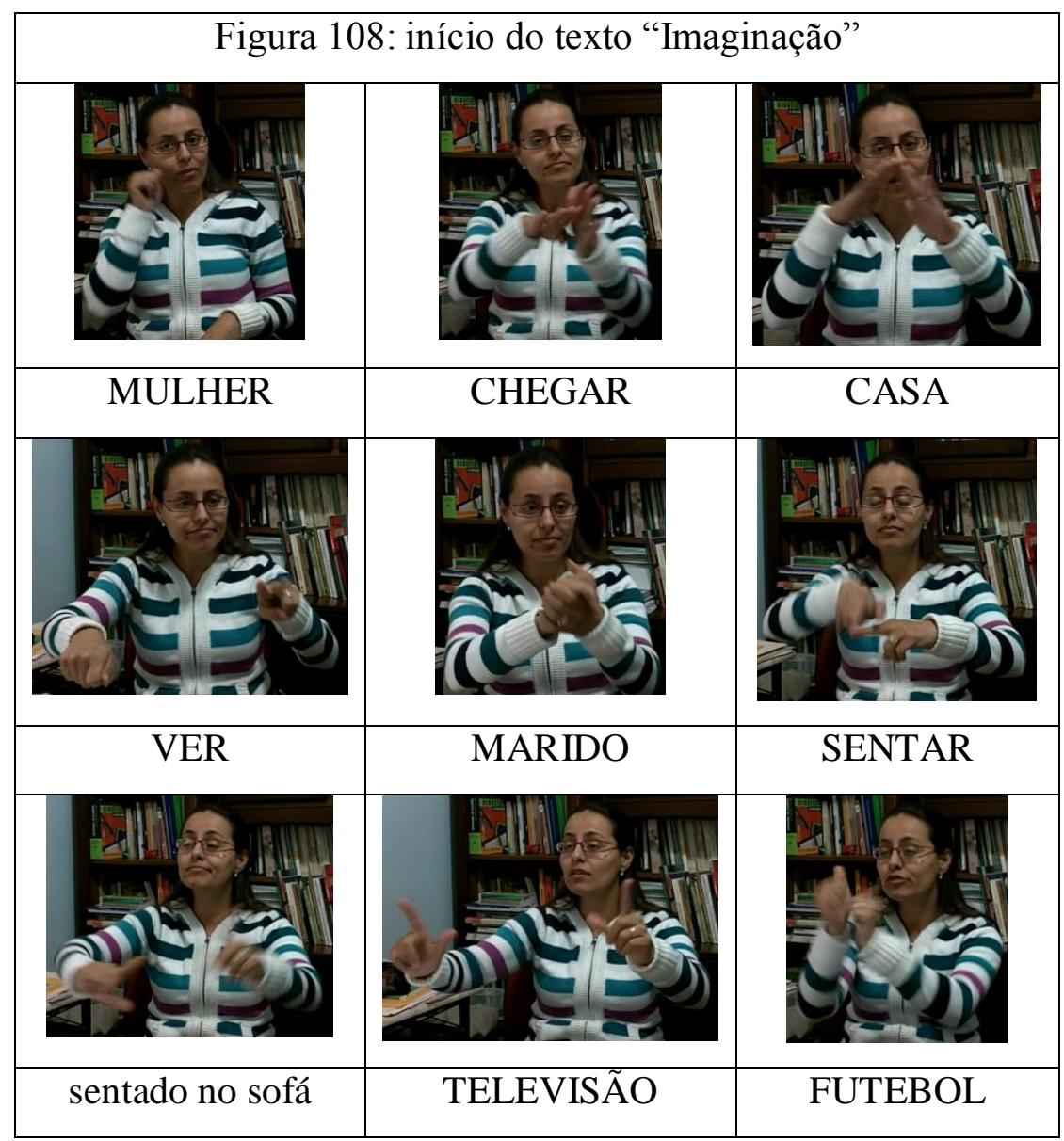

Como no texto "História do Gibi 1", também o narrador, ao mesmo tempo que narra, demonstra as ações das personagens, alterando a posição do corpo, a direção do olhar, como já foi mostrado. O tempo, novamente, pode ser interpretado a partir da pessoa e do espaço. Sendo enuncivas essas categorias e a categoria de tempo neutralizada por elas, teríamos um texto organizado a partir de um ponto referencial enuncivo, não concomitante ao ME.

Essa possível neutralização temporal também pode ser notada em outro texto do corpus da pesquisa. Em "Sonhos", de Neiva, a ancoragem de tempo realizada no início da história também não é explícita. Nos primeiros instantes da sinalização desse texto, já se percebe a debreagem enunciva de espaço (há a realização de um espaço de um escritório, com o sinal REUNIÃO) e de pessoa (há a realização do sinal de MULHER). A narração é feita, então, em 
terceira pessoa. Não há, no entanto, as marcas gestuais que, nos outros textos analisados, indicavam um tempo enuncivo ou uma anterioridade do MR, como tronco inclinado para trás, olhar desviado do narratário. De novo, a gestualidade presente é mais enunciativa, ou, comparando com a "História do Gibi 1" e "Imaginação", talvez, mais neutra.

Como é possível observar, na figura 109, abaixo, o narrador olha para seu narratário durante toda a sinalização do início da história e seu tronco se encontra na posição neutra, marcando apenas a instauração de um narrador, direcionado a seu narratário.

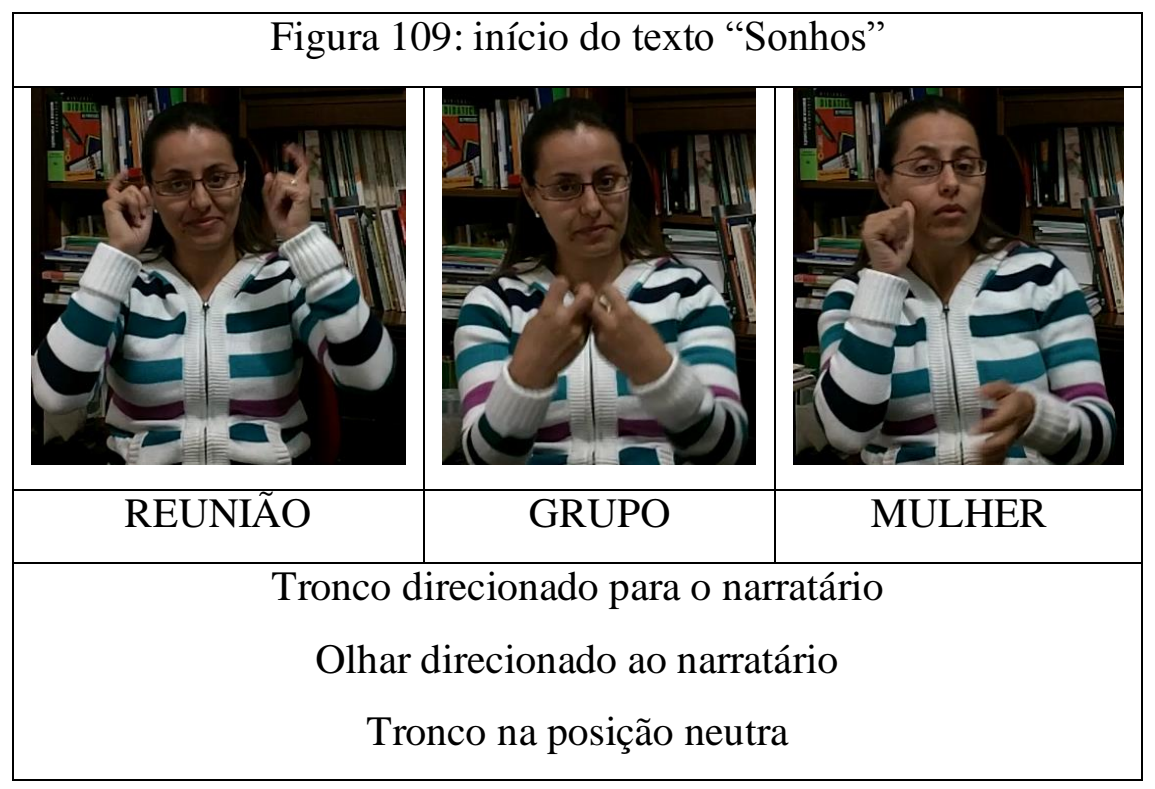

Pode-se supor que, para entender o tempo, em textos como "Sonhos", é preciso considerar as debreagens de pessoa e espaço e considerar a possibilidade de a marcação temporal será dada a partir dessas outras categorias discursivas, como foi o caso do texto "História do Gibi 1" e em "Imaginação". Se a pessoa e o espaço são enuncivos, então, o tempo também será, embora a gestualidade presente não indique isso, gerando um efeito de presentificação das ações mesmo assim.

Em outro texto do corpus, "História do Gibi 2", sinalizada pela surda Regiane Agrella, temos mais um exemplo da instauração de um sistema temporal enuncivo. Não é realizado o sinal de PASSADO, logo no início da história, como ocorreu em "O amor é surdo", mas a ancoragem temporal é dada pela instauração da terceira pessoa. Depois de um nível da narração, como na "História do Gibi 1", em que há a apresentação do que será contado, o nível do narrado da "História do Gibi 2" começa. Nele já há, logo de início, uma debreagem enunciva de pessoa. O olhar e o tronco do narrador estão direcionados para o narratário. Além disso, há, na realização do 
sinal VER, a oralização do verbo "ver" do português, no passado, como se pode notar nas imagens da figura 110, abaixo.

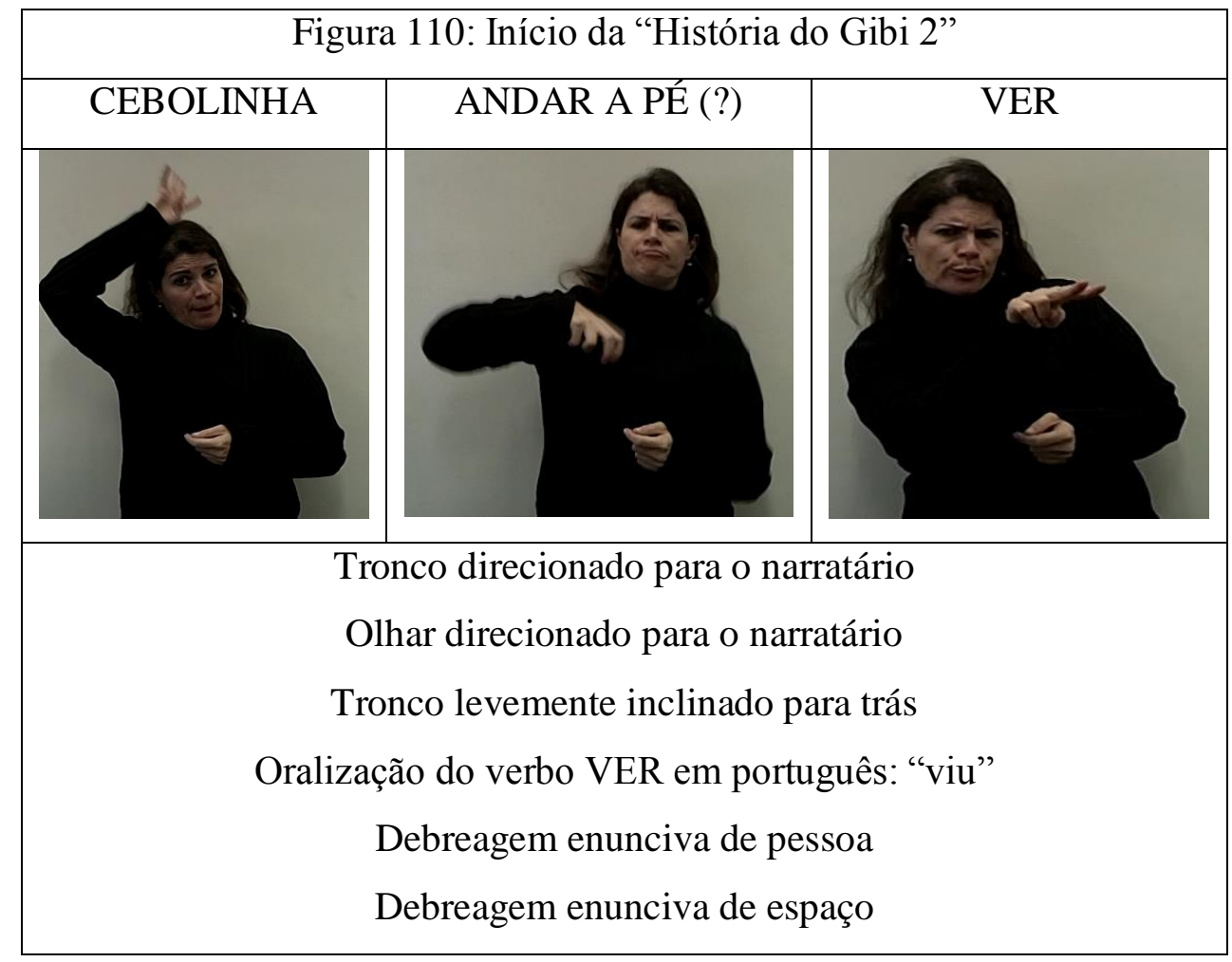

É possível perceber que o corpo sofre alterações, principalmente na realização do sinal VER, mas isso porque, como já foi mostrado nos outros textos, o narrador pode narrar e demonstrar a ação da personagem ao mesmo tempo. No final desse trecho apresentado na figura acima, é possível ver o momento em que narrador marca a posição da personagem Cebolinha, na história, e, enquanto narra que ele viu a Magali, já cria toda uma gestualidade do menino olhando para sua amiga. O fato de a oralização do verbo em português, no passado, acompanhar a sinalização de VER, pode corroborar com a ideia de tempo enuncivo desse texto. Pode-se dizer que, na "História do Gibi 2", o tempo instaurado é enuncivo, não concomitante ao ME, e que a debreagem enunciva de pessoa pode ser a responsável por essa organização temporal enunciva, aparentemente indefinida no discurso. Os intérpretes consultados durante a análise desses dados, confirmam que o tempo instaurado é passado e, ao interpretarem o discurso em libras para o português, eles usam o pretérito perfeito.

Com a análise apresentada nesta seção, considerando uma possível embreagem heterocategórica sendo responsável pela instauração do tempo, em alguns textos do corpus, podemos concluir que, dessa forma, não haveria textos em que o tempo é indeterminado, como 
sugerem alguns estudos sobre o assunto. Nos enunciados analisados, o tempo parece ter sido neutralizado pelas categorias de pessoa e espaço e marcados, assim, da forma como essas outras categorias foram marcadas. Isso, no entanto, precisa ser mais bem investigado em pesquisas futuras.

\section{3) Os efeitos de sentido da marcação temporal em libras}

Entre os efeitos de sentidos que puderam ser identificados nos textos analisados e que foram gerados, em especial, pela marcação temporal, podemos citar (i) o efeito de proximidade, de uma ilusão enunciativa, uma presentificação, tanto de fatos passados quanto de fatos futuros, gerados por debreagens enunciativas de tempo e, também e especialmente, pelas embreagens enunciativas (homocategóricas ou heterocategóricas), e (ii) efeitos de distanciamento, virtualidade, despresentificação, gerados por debreagens e embreagens enuncivas de tempo.

Nos enunciados narrados no presente, como no nível da narração do texto "História do Gibi 1", "Metáfora - O escorpião e a tartaruga", "Minha Vida", por exemplo, em que o MA é concomitante ao MR presente, temos uma simulação do tempo do agora. Como toda a gestualidade que ajuda a indicar presente, como o corpo e o olhar do narrador direcionados para o narratário, aproxima o que é narrado do enunciatário, diante de um texto sinalizado, podemos ter a mesma ilusão que se tem diante de um texto fílmico, por exemplo. A sensação é a de que tudo está acontecendo no aqui e no agora, perante os nossos olhos (o "presente do passado" ou o "presente do futuro"). Nas debreagens internas, temos ainda com mais intensidade esse simulacro do momento da enunciação. Nesses momentos em que há de fato a instauração de um MR presente, as vozes do narrador e das personagens são sincretizadas, se misturam, e se apresentam em um único corpo. Além disso, há muitas demonstrações de ação das personagens, o que gera um efeito de realidade maior ainda. Toda essa sinalização faz parte da figurativização do nível discursivo e, juntamente com a forma como o tempo é organizado e instaurado, ajudam a criar esses efeitos de sentido de verdade, proximidade, realidade, e a presentificar os fatos que estão sendo narrados.

No nível do narrado, em textos como "História do Gibi 1", também se nota um efeito de sentido muito interessante, gerado possivelmente por uma embreagem heterocategórica de tempo. Como foi mostrado na seção anterior, as marcas de tempo foram neutralizadas pelas categorias de pessoa e espaço, parecendo estar indefinidas. As categorias enuncivas de pessoa e espaço criam no texto o efeito de sentido de distanciamento, virtualidade, o que faz com que o que se vê seja 
entendido como ficcional, não pertencendo à realidade. Mas a intensa figuratividade que a língua permite, a iconização forte presente nos enunciados fazem com que também haja um efeito de sentido de presentificação dos fatos e, por isso, muitas vezes se tem a sensação de se tratar de um presente gnômico.

O que se nota, nos textos analisados, é que, mesmo em enunciados organizados a partir de um sistema temporal enuncivo, temos momentos da história, como esses da "História do Gibi 1", em que há uma ilusão enunciativa, uma presentificação de fatos que são na verdade anteriores ao ME. Uma explicação possível para isso pode ser o fato de o narrador poder narrar e, simultaneamente, poder demonstrar as ações narradas, o que parece causar a ilusão de um sistema temporal enunciativo o tempo todo, mesmo quando a narrativa toda é formada a partir de um ponto de referência enuncivo, como ocorre no texto "O amor é surdo".

\section{4) Considerações finais do capítulo}

Este capítulo teve como objetivo apresentar uma descrição dos procedimentos de temporalização de discursos em libras, seguindo a proposta teórico-metodológica da semiótica discursiva francesa para o estudo da enunciação. Foram analisados os textos "História do Gibi 1", "História do Gibi 2", "O amor é surdo", "Minha Vida", "Sonhos" e "Metáfora - O escorpião e a tartaruga". Além disso, foram apresentados exemplos de outros textos também estudados, como "Imaginação", "Dúvida", "Explicação", "Aula de História” e "Sonho com um carro novo", que também fazem parte do corpus da pesquisa, para que fosse possível verificar a recorrência das estratégias de tempo descritas.

Os dados analisados mostram que, como já tinha sido apontado por outros estudos sobre outras línguas de sinais do mundo, como a ASL e a língua de sinais belgo-francesa, e a própria libras, a marcação de tempo nas línguas sinalizadas pode ser realizada por itens lexicais específicos de tempos, como advérbios e expressões adverbiais da língua, produzidos por gestos manuais, e também por outros elementos gramaticais e discursivos, produzidos por gestos não manuais, como direção do olhar, movimento do tronco e localização das mãos no espaço, que são, na verdade, responsáveis pela instauração de pessoa e espaço e que podem dar pista do tempo que está sendo instaurado. Os gestos identificados, na literatura, como os responsáveis por instaurar o tempo nos textos analisados, e também podem, simultaneamente, indicar mudança de instância enunciativa, contribuir com a instauração de pessoa e de espaço no discurso e não são. 
Também foi possível verificar os possíveis efeitos de sentido gerados pelas debreagens e embreagens, responsáveis pela localização temporal nos discursos sinalizados.

Segue, abaixo, uma síntese dos resultados obtidos com a descrição e análise propostas:

1) A partir da identificação do MR de cada um dos textos, considerando os dois níveis enunciativos (da narração e do narrado), foi possível levantar as formas que a língua dispõe para instaurar neles um sistema temporal enunciativo ou um sistema temporal enuncivo:

a) Nos textos analisados, sempre apareceram marcas de concomitância entre o acontecimento narrado e o presente da enunciação e as categorias de pessoa e de espaço são enunciativas:

(i) Houve a realização dos itens lexicais AGORA (2) e HOJE (2) que indicam tempo presente, instaurando o sistema enunciativo, nos textos "História do Gibi 1", "Metáfora - O escorpião e a tartaruga", "Minha vida" e nos "Exemplos - Neiva";

(ii) O tronco e olhar do narrador estavam direcionados ao narratário, em todos os textos em que houve a marcação de presente;

(iii) O tronco e o olhar, nos discursos diretos, estavam direcionados ao interlocutário, sem inclinação do corpo para frente ou para trás;

(iii) Os sinais manuais foram realizados mais próximos e na frente do corpo do sinalizador;

(iv) Os tempos anteriores e posteriores ao presente foram marcados pelos advérbios enunciativos ONTEM e AMANHÃ, nos textos dos "Exemplos-Neiva";

b) Nos textos analisados, sempre aparecem marcas da não-concomitância do evento narrado com o presente da enunciação (ME) ou com o MR instaurado em cada texto estudado: 
(i) Houve a realização dos itens lexicais PASSADO, ACONTECER (O QUE), nos textos "O amor é surdo", "Exemplos-Neiva", "Minha vida" e "Metáfora - O escorpião e a tartaruga", para expressar o tempo enuncivo passado;

(ii) Houve a realização dos itens lexicais IMAGINAR, FUTURO e SE, para expressar futuro, nos textos "História do Gibi 1", "Sonhos", "Sonho com um carro novo", "Explicação" e "Imaginação";

(iii) Localização das mãos foi distanciada do corpo, quando o evento estava situado no futuro, nos textos "História do Gibi 1", "Metáfora - O escorpião e a tartaruga", "Sonho com um carro novo";

(iv) Movimento do tronco foi para frente, quando havia marcas lexicais de futuro nos textos;

(V) Movimento do tronco foi para trás, quando havia uma marca lexical de passado nos textos;

(vi) A direção do olhar parece ser a marca mais contundente no estabelecimento de um sistema temporal enunciativo e de um sistema temporal enuncivo por meio de uma embreagem heterocategórica. Houve desvio do olhar do narrador em todos os textos que marcaram a nãoconcomitância com o presente: olhar para o horizonte; olhar para baixo ou para as mãos que realizam um sinal; olhos fechados durante um sinal de ação. Esse desvio do olhar marcava espaço e pessoa enuncivos;

(vii) Na realização de ONTEM e AMANHÃ, do sistema enunciativo, houve mudança no posicionamento do tronco do sinalizador, como ocorreu nos tempos (passado e futuro) do sistema enuncivo;

(viii) Quando não há a realização de itens lexicais que indicam tempo e apenas os elementos corporais marcam a não-concomitância do MA com o ME, podemos dizer que estamos diante de um sistema temporal enunciativo, que o MR instaurado foi o presente e que os gestos de tronco, olhar e localização dos sinais estão indicando a anterioridade ou posterioridade do fato narrado; 
(ix) Os textos em que o sistema temporal instaurado é enuncivo sempre há uma marca lexical, acompanhada ou não de outros elementos gestuais, para indicar a não-concomitância desse MR com o ME;

As tabelas, abaixo, apresentam, de forma esquemática, o conjunto de estratégias gramaticais ou discursivas (manuais ou não) envolvidas com a instauração de tempo nos textos analisados. Na primeira, podem-se ver os elementos que instauram pessoa e espaço e que também ajudam a criar, por meio de uma embreagem heterocategórica, o tempo do sistema enunciativo e, na segunda, do sistema enuncivo:

\begin{tabular}{|c|c|c|c|c|}
\hline \multicolumn{5}{|c|}{ SISTEMA ENUNCIATIVO DE TEMPO } \\
\hline Tempos & Itens lexicais & Olhar & Tronco & $\begin{array}{l}\text { Localização } \text { das mãos } \\
\text { durante a sinalização do } \\
\text { evento }\end{array}$ \\
\hline Presente & $\begin{array}{l}\text { AGORA (2); } \\
\text { HOJE (2) }\end{array}$ & $\begin{array}{l}\text { Olhar } \\
\text { direcionado ao } \\
\text { narratário } \\
\end{array}$ & $\begin{array}{l}\text { Tronco do narrador } \\
\text { direcionados ao } \\
\text { narratário }\end{array}$ & $\begin{array}{l}\text { Sinais realizados mais } \\
\text { próximos e na frente do } \\
\text { corpo do sinalizador }\end{array}$ \\
\hline Passado & ONTEM & $\begin{array}{l}\text { Olhar } \\
\text { direcionado ao } \\
\text { narratário }\end{array}$ & $\begin{array}{l}\text { Movimento do tronco } \\
\text { para trás parece indicar } \\
\text { passado }\end{array}$ & Sinais direcionados para trás \\
\hline Futuro & AMANHÃ & $\begin{array}{l}\text { Olhar } \\
\text { direcionado ao } \\
\text { narratário }\end{array}$ & $\begin{array}{l}\text { Movimento do tronco } \\
\text { para frente parece indicar } \\
\text { futuro }\end{array}$ & $\begin{array}{l}\text { Sinais realizados distante e à } \\
\text { frente do corpo }\end{array}$ \\
\hline
\end{tabular}

\begin{tabular}{|l|l|l|l|l|}
\hline \multicolumn{9}{|c|}{ SISTEMA ENUNCIVO DE TEMPO } \\
\hline Tempos & Itens lexicais & Olhar & $\begin{array}{l}\text { Localização das mãos durante } \\
\text { a sinalização do evento }\end{array}$ \\
\hline Passado & $\begin{array}{l}\text { ANOS } \\
\text { PASSADO } \\
\text { ATRÁS }(2) \\
\text { ACONTECER }\end{array}$ & $\begin{array}{l}\text { Desvio do olhar } \\
\text { do narrador }\end{array}$ & $\begin{array}{l}\text { Movimento do } \\
\text { tronco para trás }\end{array}$ & $\begin{array}{l}\text { Sinais realizados para trás do } \\
\text { corpo }\end{array}$ \\
\hline Futuro & $\begin{array}{l}\text { FUTURO } \\
\text { IMAGINAR } \\
\text { SE } \\
\text { EXEMPLO }\end{array}$ & $\begin{array}{l}\text { Desvio do olhar } \\
\text { do narrador }\end{array}$ & $\begin{array}{l}\text { Movimento do } \\
\text { tronco para frente }\end{array}$ & $\begin{array}{l}\text { Sinais realizados mais à frente e } \\
\text { distante do corpo }\end{array}$ \\
\hline
\end{tabular}

As tabelas registram apenas o que apareceu nos textos do corpus que foram analisados. De forma alguma, ela esgota as possibilidades que o discurso oferece para marcar o tempo, criar diferentes temporalidades em seus discursos. Além disso, os marcadores descritos a partir dos textos estudados não são invariáveis e necessariamente obrigatórios em todos os discursos. As tabelas mostram as possíveis estratégias que a língua conta para fazer sua marcação temporal. Um ponto de questionamento que esse tipo de descrição levanta é a respeito do problema em 
diferenciar, nas tabelas, os marcadores que são lexicais, realizados basicamente com as mãos, daqueles que são feitos com outras partes do corpo. Do ponto de vista da semiótica, todos eles seriam marcas gestuais e a única diferença seria o fato de alguns já estarem dicionarizados, registrados e descritos como marcadores específicos de tempo e outros, ainda não. Tem que se discutir, então, se essas outras marcas, como o movimento do tronco, a direção do olhar, localização das mãos não poderiam ser consideradas marcas gramaticais, ou se, em algum momento da língua, não serão marcas específicas de tempo. Este trabalho optou por considerar que, nos termos de Greimas (1973), o tempo é recorrentemente marcado, em libras, de forma classemática, por meio das outras categorias enunciativas instauradas nos textos. Isso é possível, como já foi dito, por meio de uma embreagem heterocategórica.

\section{2) Nos textos, aparecem formas iguais que manifestam tempos de sistemas temporais $\operatorname{distintos}^{115}$ :}

(i) Para expressar o tempo passado do sistema enunciativo, nos "Exemplos-Neiva", e tempo passado do sistema enuncivo ("O amor é surdo", por exemplo), é realizada a mesma marca corporal: tronco para trás;

(ii) Para expressar o tempo futuro do sistema enunciativo, nos "Exemplos - Neiva", e tempo futuro do sistema enuncivo ("Sonho com um carro novo", por exemplo), é realizada a mesma marca corporal: tronco para frente;

(iii) A diferença entre esses tempos (passado e futuro) enunciativos e tempos (passado e futuro) enuncivos é a direção do olhar. Nos tempos enunciativos, o olhar é direcionado para o narratário e, nos tempos enuncivos, ele é desviado ou está fechado.

\footnotetext{
${ }^{115}$ Fiorin (2012) mostra que, em português brasileiro, a forma verbal do pretérito imperfeito tem um valor durativo que pode ser contínuo ou descontínuo. Esse tempo verbal pode, portanto, expressar um fato que se repete no passado quanto um fato contínuo, e é o contexto criado no enunciado que permitirá uma ou outra interpretação. No caso do pretérito perfeito, também há um comportamento interessante. A mesma forma verbal pode cobrir dois tempos distintos, que pertencem a diferentes sistemas, como foi mostrado no capítulo 1 desta tese: um tempo passado do sistema enunciativo, e um tempo concomitante ao MR passado, do sistema enuncivo.
} 


\section{3) Foi identificada uma diferença entre um passado próximo e um passado distante: mudança na articulação do próprio sinal PASSADO:}

(i) No texto "Exemplos-Neiva", em que aparece um passado mais recente, o sinal é realizado de forma acelerada, com movimentos curtos das mãos, braços mais fechados e próximos ao corpo;

(ii) No texto "Metáfora - O escorpião e a tartaruga", em que aparece um passado mais distante, o sinal é realizado de forma desacelerada, com o movimento longo das mãos, braços abertos e mais distanciados do corpo;

4) Foi levantada uma hipótese a respeito das embreagens homocategóricas de tempo que aparecem em alguns dos textos analisados:

(i) A neutralização de termos de uma oposição entre as categorias de tempo parece ocorrer quando há uma neutralização de alguns elementos da gestualidade. A marca da embreagem não está em um morfema (flexional), em um verbo, como ocorre em uma língua como o português, mas sim, em um conjunto de elementos envolvidos com a construção das relações temporais. Mesmo quando um item lexical que indica tempo é usado, esse conjunto de gestos corporais pode indicar outro tempo no lugar daquele originalmente debreado.

5) Foi levantada a hipótese de que, de alguma forma, em todos os textos do corpus, com destaque a "História do Gibi 1", "Imaginação", "Sonhos" e "História do Gibi 2", o tempo foi marcado por meio de uma embreagem heterocategórica:

(i) O tempo é projetado no espaço como as demais categorias enunciativas e depende dele para ser estruturado discursivamente;

(ii) Os mesmos gestos envolvidos na marcação de pessoa e criação de espaços de referência nos textos estão relacionados com a marcação temporal, uma vez que há uma neutralização dessas categorias;

(iii) Os gestos não manuais e gestos manuais (itens lexicais) podem concordar durante a marcação de tempo; 
(iv) Os gestos manuais e não manuais se organizam espacialmente seguindo uma linha de tempo imaginária, projetada no espaço de sinalização. Essa linha não é fixa. Foram identificadas, nos textos em libras, os três tipos de linhas de tempo possíveis, identificadas por Johnston \& Schembri (2007): (i) a dêitica (perpendicular ao corpo), como nos textos "Minha Vida", "Metáfora - O escorpião e a tartaruga", por exemplo, (ii) a anafórica (diagonal ao corpo), em dois diálogos de "História do Gibi 1", por exemplo, e (iii) a sequencial (paralela ao corpo), no texto "Aula de História";

(v) Nas debreagens enunciativas internas, quando não aparece um item lexical, o tempo é marcado por meio da neutralização de tempo e espaço, portanto, portanto, por uma embreagem heterocategórica.

Esta pesquisa mostrou que, para estudar a organização temporal, é necessário considerar as possíveis relações entre a localização dos sinais no espaço de sinalização e o corpo do sinalizador, descrevendo todos os detalhes envolvidos na construção dos enunciados sinalizados, como as expressões faciais e a realização de alguns sinais específicos. Esse conjunto de elementos gestuais caracteriza a forma como as debreagens e as embreagens procedem para realizar o processo de discursivização, não só da categoria de tempo, mas principalmente de pessoa e espaço na língua.

Foi possível perceber, portanto, que o tempo pode ser marcado por meio das outras categorias enunciativas (pessoa e espaço). A embreagem heterocategórica, recurso que, além de parecer muito produtivo em uma língua que conta com o visual e com o espaço para criar seus discursos, gera o efeito de sentido de uma ilusão enunciativa, que nos dá a sensação de sempre estar acompanhando os acontecimentos narrados como se estivessem no agora. Essa proximidade que a embreagem cria nos textos gera efeitos de verdade e realidade e permite, ao que parece, que os textos sejam mais figurativos e explorem seus recursos visuais e icônicos. 


\section{Conclusão}

"Se lembra quando a gente

Chegou um dia a acreditar

Que tudo era pra sempre

Sem saber que o pra sempre sempre acaba"

Por enquanto

Legião Urbana

Esta tese teve como objetivo apresentar uma descrição da temporalização, em especial, da localização temporal, no nível discursivo do plano do conteúdo dos textos em língua de sinais brasileira (libras), no âmbito da teoria semiótica greimasiana. No capitulo 1, resenhamos a teoria de tempo sobre a qual a pesquisa se sustenta, destacando os conceitos de enunciação, tempo linguístico e os mecanismos de instauração temporal e seus efeitos de sentido. No capítulo 2, discorremos sobre alguns estudos sobre a marcação de tempo em outras línguas de sinais e algumas divergências nessas abordagens sobre o assunto. No capítulo 3, comentamos a metodologia de descrição que foi adotada, a construção do corpus e a transcrição de dados no ELAN, e, no capítulo 4, apresentamos a descrição e a análise dos textos sinalizados, com seus resultados, que apontam as características peculiares da organização do tempo em libras.

A tese partiu de estudos sobre as línguas de sinais (ver Alkoby (s/d), Sinte, 2013, Johnston \& Schembri, 2007 e Finau, 2004), que já apontam que essas línguas apresentam os mecanismos gerais de enunciação. Esses pesquisadores, no entanto, afirmam que a marcação do tempo não é feita por meio de morfemas flexionais presentes nos verbos, mas sim por outros elementos linguísticos e discursivos, como gestos manuais, como itens lexicais, convencionais, já dicionarizados, responsáveis pela referência temporal, e outros gestos não manuais, como movimento do tronco, da cabeça, localização das mãos no espaço e a direção do olhar do sinalizador, que estão envolvidos, de alguma forma, na criação e organização dos diferentes tempos no interior dos textos sinalizados.

Estudiosos sobre várias línguas de sinais do mundo também apresentam esses mesmos gestos, manuais e não manuais, relacionados com a marcação temporal nos mais variados discursos, o que reforça a ideia de que as línguas visuais contam, como qualquer outra língua sonora e qualquer outra linguagem, com marcas próprias de seu plano de expressão, e que, 
independentemente da manifestação de suas categorias enunciativas, contam com um aparelho formal de enunciação como qualquer outro sistema semiótico.

As particularidades na construção do tempo nas línguas de sinais, entretanto, vão além apenas da diferença de expressão dessa categoria do plano do conteúdo. A pesquisa mostrou que a libras pode marcar o tempo por meio de um léxico específico, por meio de debreagens enunciativas e enuncivas, e por meio de embreagens homocategóricas. Mas, em alguns casos, quando não há uma marca temporal específica, a língua conta com outro mecanismo discursivo, muito comum em textos sincréticos como o cinema, uma embreagem heterocategórica, que permite que, por meio de uma neutralização das categorias da enunciação (pessoa, espaço, tempo), o tempo seja construído espacialmente.

Há um conjunto de gestos não manuais variados que são responsáveis pela instauração das categorias da enunciação de um modo geral. Esses elementos, portanto, não são marcadores específicos de tempo. Conforme o contexto em que aparecem, essas marcas do corpo indicam outras informações no interior do discurso, não exatamente o tempo. Dependendo do texto, esses gestos podem acontecer devido ao tipo de articulação dos itens lexicais presentes na sinalização ou por razões discursivas diversas: o tipo de figurativização do texto (presença de pantomimas para demonstrar as personagens e as ações narradas), a instauração de pessoa e de espaço.

Esse conjunto de estratégias visuais que aparecem nos textos do corpus, que incluem também os itens lexicais que indicam tempo, realizados por gestos manuais, pode ser entendido como classemático, nos termos de Greimas (1973), pois seriam um conjunto de semas relacionados com as categorias da enunciação (pessoa, espaço e tempo) de um modo geral. Se o movimento do corpo, por exemplo, marcou um espaço específico, pode, de forma classemática, marcar também o tempo. Isso pode ocorrer justamente porque ocorre uma neutralização dessas categorias, por meio de uma embreagem heterocategórica.

Como a direção do olhar e o movimento do tronco aparecem mais nos textos em que ocorre esse tipo de embreagem, é possível levantar a hipótese de que esses elementos podem, na História dessa língua, caminhar para uma gramaticalização e se tornar até um marcador de tempo. Até este instante, esses elementos não manuais na língua são responsáveis tanto pela instauração de pessoa quanto pela criação de diferentes espaços, de forma bastante variável. Um olhar para frente do sinalizador pode marcar primeira pessoa ou apenas a instância enunciativa do narrador, não necessariamente em primeira pessoa. $\mathrm{O}$ corpo inclinado para frente pode marcar pessoa, ao ser uma forma de demonstrar como a personagem de uma história, por exemplo, está ou o que fez. O movimento do corpo para trás, para o lado e as diferenças na direção do olhar, durante a 
sinalização também marcam o espaço. Em um texto em que não há um marcador explícito de tempo, como os gestos manuais, considerados itens lexicais que fazem referência temporal, esses outros elementos, que marcaram pessoa e espaço, podem marcar diferenças temporais ao se neutralizarem e construírem as relações enunciativas do texto. O trabalho procurou mostrar que marcas de pessoa e que marcas de espaço foram recorrentes para a construção de cada tempo e que essas neutralizações criam certos efeitos de sentido, como presentificação dos fatos.

Nesse sentido, defendemos a tese de que o tempo pode ser marcado por meio de uma embreagem heterocategórica e que, mesmo quando não parece haver evidências temporais nos textos, ele pode ser construído juntamente com as debreagens de pessoa e espaço. Desse modo, não há textos em que o tempo é indeterminado, como sugerem alguns estudos sobre o assunto. Foi o caso, no corpus desta pesquisa, dos textos "História do Gibi 1", "Imaginação", "Sonhos" e "História do Gibi 2". A debreagem de pessoa e espaço, sendo enuncivas, parece fazer com que interpretemos o tempo desses textos não como sendo presente (histórico ou gnómico, como se costuma supor, em um primeiro contato com essas sinalizações), mas como um passado, embora haja uma ausência de marcas lexicais ou gestuais de não-concomitância com o ME, no início dessas histórias, para marcar esse tempo enuncivo.

A ideia de ocorrer uma embreagem heterocategórica na marcação temporal é muito plausível, quando se leva em consideração o fato de as línguas de sinais manifestarem seus enunciados no espaço e projetarem nele entidades às quais se podem referir e onde se podem construir diferentes locais e diferentes momentos dos eventos narrados. O tempo é projetado no espaço como as demais categorias enunciativas e depende dele para ser estruturado discursivamente. Como as línguas sinalizadas são gestuais, o corpo também ganha uma dimensão enorme nesse espaço de sinalização e se torna um ponto de referência, a partir do qual todas as relações temporais são criadas. Diante disso, é possível entender que a linha de tempo que a literatura afirma existir como algo fixo - a parte de trás do corpo do sinalizador indica passado; a parte da frente, futuro, e o espaço central, presente -, independente de qualquer discurso, e por meio da qual os outros gestos são criados, os movimentos do corpo ocorrem, de forma mais variável e dependente de outras questões discursivas. Nesse sentido, podemos entender que a linha de tempo é criada a partir desses gestos não manuais que ocorrem durante a sinalização, e, por isso, é dinâmica.

O fato de não haver morfemas que indiquem tempo não significa dizer que as línguas de sinais não apresentam um sistema temporal estruturado como sugerido em Fiorin (2002). Segundo Lyons (1968: 304 -305), as relações de tempo são sempre expressas por contrates 
gramaticais sistemáticos. Mas não parece ser um absurdo considerar que essas marcas que nos dão pistas sobre a organização temporal e faça as distinções necessárias entre as relações entre presente, passado e futuro, nas línguas de sinais, tenham que ser necessariamente marcas específicas de tempo.

O fato de não haver marcas específicas não quer dizer que não exista nenhuma marca. Como já foi dito, existe um conjunto delas. Nesse conjunto, as marcas mais constantes e, talvez, invariáveis sejam os itens lexicais específicos de tempo. O que foi possível perceber é que, de modo geral, as marcas lexicais, por exemplo, que indicam o passado e o futuro, do sistema enunciativo ou do sistema enuncivo, podem ser as mesmas, articuladas da mesma maneira, independentemente do discurso, e possuírem a mesma forma de expressão, ou se realizarem de formas diferentes, mas acompanhadas da mesma marca corporal, por exemplo, quando expressam o passado e o futuro, tanto em textos que apresentam um sistema enunciativo de tempo como em textos em que o sistema temporal é enuncivo.

Essa distinção entre textos enuncivos e enunciativos foi possível a partir da observação de marcas iniciais dos enunciados dos textos, que indicavam o MR a partir do qual ele se organizou. Pareceu claro que, em libras, há sempre uma forma de distinguir o que é concomitante ao ME (tempos enunciativos) e o que não é concomitante (tempos enuncivos). Em geral, foi observado que essa distinção é sempre marcada por itens lexicais que indicam tempo. Mas também foi possível notar, então, que, entre as diferentes estratégias envolvidas na marcação temporal, a direção do olhar parece ajudar na diferenciação, em textos em libras, do sistema temporal enunciativo do sistema temporal enuncivo, marcando a concomitância e a não-concomitância do fato narrado com o momento da enunciação. Itens lexicais, como IMAGINAR, SE, EXEMPLO, ACONTECER apareceram no texto como detonadores de um novo espaço e tempo no interior dos textos, marcando também uma não-concomitância com o presente. Além disso, mudanças no movimento do sinal PASSADO, por exemplo, em diferentes textos da língua, parece distinguir o passado próximo do passado distante. Tudo isso revela um sistema por trás de uma produção variável e um aparelho formal de enunciação bastante complexo.

Embora esses resultados apresentados ainda não sejam conclusivos, pois exigem mais estudos, experimentos que possam testar a descrição proposta, o trabalho suscitou questões para trabalhos futuros e levantou hipóteses de investigação que podem ser um início para as próximas pesquisas tanto sobre a gramática quanto para o discurso em libras, em especial, sobre a categoria de tempo: 
1) Será preciso verificar essa hipótese de a marcação do tempo se dar pela instauração de outras categorias do discurso, como a pessoa e o espaço, como foi levantado, e, se for possível, comparar os textos em libras com textos narrados em português, em que parece ser, grande parte das vezes, o espaço, e não o tempo, a categoria instaurada por uma embreagem heterocategórica. Em muitas línguas orais, o tempo, a maior parte das vezes, é marcado por debreagens, por meio de morfemas de flexão verbal, como em português. Nas línguas de sinais, essa marcação também acontece por meio de debreagens, com sinais manuais de tempo apenas, mas é amplamente feita por embreagens.

2) Será necessário observar melhor, também, com mais dados, como ocorrem, em libras, as marcações de passado distante e passado próximo, e de futuro distante e futuro próximo, já observadas pela literatura sobre o tempo nas línguas de sinais e apontadas brevemente nesta tese.

3) Outra questão de investigação futura é a de verificar se a libras pode instaurar o tempo em seus textos de maneira parecida, por exemplo, com ao modo como os textos cinematográficos o fazem $^{116}$. Stokoe (1979) foi o primeiro a usar os recursos do cinema para descrever as línguas de sinais, pois, para ele, essas línguas apresentam uma gramática cinemática. McCleary \& Viotti (2010, 2011 e 2014) vêm mostrando, em suas pesquisas sobre libras, que os sinalizadores usam técnicas bastante análogas às do cinema ao construir seus textos ${ }^{117}$. Outros autores, como Sacks (2010) e Silva (2009) também consideraram, em seus trabalhos, as caraterísticas cinemáticas das línguas de sinais.

\footnotetext{
${ }^{116}$ A possibilidade de analisar o tempo em libras, usando a linguagem cinematográfica, e de fazer uma comparação do tempo desses textos sinalizados com o cinema foi apontada, pela primeira vez, por Norma Discini (USP). A observação foi reiterada por José Luiz Fiorin (USP), por Esmeralda Vailati Negrão (USP) e por Waldir Beividas (USP), durante apresentações de minha pesquisa, em eventos acadêmicos. Isso reforça a ideia de que, para estudar as línguas de sinais, talvez seja necessário levar em consideração aspectos visuais que compõem as manifestações linguísticas ainda poucos considerados pela Linguística tradicional, como gestos que acompanham as falas, por exemplo.

${ }^{117}$ Greimas \& Courtés (2012: 467) consideram o cinema como um exemplo de texto sincrético, porque ele aciona várias linguagens de manifestações para a constituição do seu sentido. Os textos sinalizados também podem ser considerados textos sincréticos, ou seja, textos que possuem uma forma de expressão que pode neutralizar várias substâncias de expressão (elementos corporais, topológicos) e conteúdos sob uma estratégia de enunciação única.
} 
4) Também será interessante verificar que a marcação temporal tanto do cinema quanto de línguas orais em uso (contação de histórias em português, por exemplo) pode ser muito parecida com o que acontece nas línguas de sinais, pois, nesses casos, há uma exploração maior de recursos, visuais e gestuais, que permite que se organize e instaure o tempo no enunciado $^{118}$.

5) Um próximo passo que este trabalho, sem dúvida, sugere é o do estudo do aspecto, diretamente relacionado à marcação temporal e que, por razões diversas, acabou ficando fora do foco desta pesquisa.

Resumidamente, então, pode-se dizer que, nesta tese, foi possível identificar particularidades da organização temporal em libras, levantar alguns pontos de discussão e elaborar hipóteses que podem incentivar trabalhos futuros. O trabalho que apresentei procurou olhar para as línguas de sinais de um modo novo, sem se preocupar em aproximar os resultados obtidos com o que se pode encontrar nas línguas orais, e oferecer, de algum modo, uma contribuição ao projeto de descrição da gramática de libras, iniciado pelos primeiros trabalhos sobre a língua da década de 80 e em grande expansão por todo o país atualmente.

Espero que esta pesquisa também possa contribuir com os estudos sobre metodologia de ensino de libras para surdos e ouvintes e inspirar novos trabalhos, tanto na área de Linguística quanto na área de Semiótica, sobre as línguas de sinais, respeitando suas particularidades visuaisgestuais, e ampliando o entendimento do que vem a ser as línguas humanas e as facetas discursivas de toda e qualquer linguagem, com seus diferentes planos de expressão.

\footnotetext{
${ }^{118}$ Nas línguas orais, há, juntamente com o verbal, o uso da prosódia e dos gestos que acompanham a fala, na construção dos textos, e, portanto, a marcação temporal também pode apresentar características parecidas com as línguas de sinais ou com o próprio cinema.
} 


\section{Referências bibliográficas}

ALKOBY, K. A survey of ASL tenses. Chicago, DePaul University [ms]. Acessado em 20/09/2014: http://facweb.cs.depaul.edu/research/TechReports/TR00-002.pdf, s/d.

ALMEIDA, M. Time in narratives. In: DUCHAN, J.; BRUDER, G.; HEWITTI, L. Deixis in narrative: A cognitive Science Perspective. Hillsdale, NJ: Lawrence Erlbaum, 1995.

AMARAL, M.; COUTINHO, A.; MARTINS, M. Para uma gramática da língua gestual portuguesa. Lisboa: Editorial Caminho, 1994.

BARROS, D. L. P. de. Teoria do discurso: fundamentos semióticos. 2. ed. São Paulo: Humanitas, 2001.

BARROS, D. L. P. de. Os sentidos da gestualidade. Cadernos de Semiótica Aplicada (CASA), Vol.8 n.2, 2010.

BARROS, D. L. P. de. Teoria semiótica do texto. $5^{\text {a }}$ ed. São Paulo: Ática, 2011.

BARROS, D. L. P. de. Algumas reflexões semióticas sobre a enunciação. In: FANTI, M. da G. di.; BARBISAN, L. B. (orgs.). Enunciação e Discurso. Tramas de sentidos. São Paulo: Contexto, 2012.

BARROS, M. L. P. de. O discurso da memória. Entre o sensível e o inteligível. Tese de doutorado. São Paulo: Universidade de São Paulo (USP), 2011.

BARTHES, R. [et al.]. Análise estrutural da narrativa. Petrópolis, RJ: Vozes, 2011[1971].

BEIVIDAS, W. Semióticas sincréticas (o cinema). Posições. São Paulo: Universidade de São Paulo, 2006.

BENVENISTE, E. Problemas de linguística geral I. 4. ed. Tradução em português: Maria da Glória Novak e Maria Luisa Néri. Campinas: Pontes, v. 1, 2005[1976].

BENVENISTE, E. Problemas de linguística geral II. 2. ed. Campinas: Pontes, v. 2, 2006 [1974].

BERTRAND, D. Caminhos da semiótica literária. Bauru, SP: EDUSC, 2003.

BERTRAND, D; FONTANILLE, J. Régimes Sémiotiques de la temporalité: la flèche brisée du temps. Paris: Presses Universitaires de France, 2006.

BOLGUERONI, T. Transcrição de narrativas na língua de sinais brasileira. Relatório de Iniciação científica. São Paulo: Universidade de São Paulo (USP), 2007.

BOLGUERONI, T. B. Uma descrição da referenciação em língua de sinais brasileira (libras). Dissertação de mestrado. São Paulo: Universidade de São Paulo (USP), 2013.

BOLGUERONI, T. B.; VIOTTI, E. Referência nominal em língua de sinais brasileira (libras). Todas as Letras, v. 15, n. 1, 15-50, 2013. 
BORBA, F. da S. Pequeno vocabulário de lingüística moderna. São Paulo: Editora da USP, 1971.

CAMÕES, L. V. de. 200 Sonetos. Porto Alegre: L\&PM, 1998.

CAPOVILLA, F. C; RAPHAEL, W. C. Dicionário enciclopédico ilustrado trilíngue da língua de sinais brasileira, 1a. ed., v. 1 e 2. São Paulo: Edusp, 2001.

CAPOVILlA, F. C.; Raphael, W. D.; Mauricio, A. C. Novo Deit-Libras: Dicionário enciclopédico ilustrado trilíngue da Língua de Sinais Brasileira (Libras) baseado em Linguística e Neurociências Cognitivas, 2a. ed., v. 1e 2. São Paulo: Edusp, 2012.

CHAFE, W. The pear stories: Cognitive, cultural and linguistic aspects of narrative production. Norwood, New Jersey: Alelix, 1980.

CHAFE, W. Discourse, consciousness, and time. Chicago/Londres: The University of Chicago Press, 1994.

CLARK, H. Using language. New York: Cambridge University Press, 1996.

CLARK, H. \& GERRIG, R. Quotations as demonstrations. Language, 66, 764-805, 1990.

COMRIE, B. Tense. Cambridge: Cambridge University Press, 1985.

CORÔA, M. L. M. S. O tempo nos verbos do português. São Paulo: Parábola, 2005.

CORMIER, K.; SCHEMBRI, A.; WOLL, B. Pronouns and pointing in sign language. Lingua, 137: 230-247, 2013.

COSNIER, J.; VAYSSE, J. Sémiotique des gestes communicatifs. Nouveaux Actes Semiotiques, 52-53-54. Faculté des Lettres et des Sciences Humaines. Pulim: Press Universitaires de Limoges, 1997.

CUTRER, M. Time and tense in narrative and in everyday language. Tese de doutorado. California: University of California, 1994.

DAHL, O. Tense and Aspect systems. Basil Blackwell: New York, 1985.

DOWTY, D. R. Tense, time adverbs, and compositional semantic theory. Linguistics and Philosophy 5: 23-55, 1982.

DUCHAN, J.; BRUDER, G.; HEWITTI, L. Deixis in narrative: A cognitive Science Perspective. Hillsdale, NJ: Lawrence Erlbaum, 1995.

DUDIS, P. Body partitioning and real-space blends. Cognitive Linguistics 15-2, p. 223-238, 2004.

DUDIS, P. Types of Depiction in ASL. Washighton, DC: Gallauted University Press, 2007.

DUDIS, P. The body in scene depiction. In: ROY, C. B. (ed.) Discourse in Signed Language. Washighton, DC: Gallauted University Press, 2011. 
FAUCONNIER, G. Mental spaces: Aspects of meaning in natural language. Cambridge: Cambridge University Press, 1994.

FAUCONNIER, G.; TURNER, M. The way we think. Conceptual blending and the mind's hidden complexities. New York: Basic Books, 2002.

FELIPE DE SOUZA, T. A. A relação sintático-semântica dos verbos e seus argumentos na língua brasileira de sinais (LIBRAS). Tese de doutorado. Rio de Janeiro: Universidade Federal do Rio de Janeiro (UFRJ), 1998.

FERREIRA-BRITO, L. Similarities and Differences in Two Sign Languages. Sign Language Studies. 42: 45-46. Silver Spring, USA: Linstok Press, 1984.

FERREIRA-BRITO, L. Por uma gramática das línguas de sinais. Rio de Janeiro: Tempo Brasileiro, 1995.

FERREIRA-BRITO, L. Epistemic, Alethic, and Deontic Modalities in a Brazilian Sign Language. In: FISHER, S. D.; SIPLE, P. (eds.). Theoretical Issues in Sign Language Research. Vol. 1. University of Chicago Press, 1990.

FIORIN, J. L. A noção de texto na semiótica. Ms., p. 1-10, 1994.

FIORIN, J. L. Enunciação e construção do sentido. In: Valente, A. (Org.). Aulas de português. Perspectivas inovadoras. 3. ed. Petrópolis: Editora Vozes, p. 169-189, 2001a.

FIORIN, J. L. Elementos de análise do discurso. 10. Ed. São Paulo: Contexto, 2001b.

FIORIN, J. L. As astúcias da enunciação: As categorias de pessoa, espaço e tempo. 2. ed. São Paulo: Editora Ática, 2002.

FIORIN, J. L. O projeto hjelmsleviano e a semiótica francesa. Galáxia. Revista transdisciplinar de comunicação, semiótica, cultura. Programa de Pós-Graduado em comunicação e semiótica da PUC-SP, n. 5. São Paulo: EDUC, p. 19-52, 2003.

FIORIN, J. L. Em busca de sentido: Estudos discursivos. São Paulo: Contexto, 2008a.

FIORIN, J. L. Tempo e temporalização. In: CAGLIARI, L. C. (Org.). O tempo e a linguagem. São Paulo: Cultura Acadêmica, 2008b.

FIORIN, J. L. Para uma definição das linguagens sincréticas. In: OLIVEIRA, A. C. de; TEIXEIRA, L. (Orgs.). Linguagens na comunicação: desenvolvimentos de semiótica sincrética. São Paulo: Estação das Letras e Cores, 2009.

FIORIN, J. L. Da necessidade da distinção entre texto e discurso. In: BRAIT, B.; SOUZA-ESILVA, M. C. (Org.). Texto ou discurso? São Paulo: Contexto, 2012.

FIORIN, J. L.; FLORES, V. do N. \& BARBISAN, L.B. Saussure. A invenção da Linguística. São Paulo: Contexto, 2013.

FINAU, R. Os sinais de tempo e aspecto na libras. Tese de doutorado. Paraná: Universidade Federal do Paraná, 2004. 
FLORES, V. do N.; TEIXEIRA, M. Introdução à linguística da enunciação. São Paulo: Contexto, 2005.

FLORES, V. do N. [et al.]. Enunciação e gramática. São Paulo: Contexto, 2008.

FONTANILLE, J. \& ZILBERBERG, C. Tensão e significação. Tradução de Ivã Carlos Lopes, Luiz Tatit e Waldir Beividas. São Paulo: Discurso Editorial / Humanitas, 2001.

FRIEDMAN, L. A. Space, time, and person reference in American Sign Language. Language 51(4): 940-961, 1975.

GAUDREAULT, A.; JOST, F. A narrativa cinematográfica. Brasília: Editora Universidade de Brasília, 2009.

GENETTE, G. Figures III. Paris: Seuil, 1972.

GIVON, T. The drift from VSO to SVO in Biblical Hebrew: The pragmatics of tense-aspect. In: LI, C. N. (Ed.). Mechanisms of Syntactic Change. Austin/London: University of Texas Press, 181-254, 1977.

GIVON, T. Syntax: A functional-typological introduction, v. 1. Amsterdam: John Benjamins Publishing Co., 1984.

GREIMAS, A. J. Du Sens I. Paris: Éditions du Seuil, 1970.

GREIMAS, A. J. Semântica estrutural. Pesquisa de método. São Paulo: Cultrix, 1973.

GREIMAS, A. J. Sobre o sentido I: Ensaios Semióticos. Petrópolis: Vozes, 1975.

GREIMAS, A. J. Condições para uma semiótica do mundo natural. Tradução: Manuela Torres. In: GREIMAS, A. J.; KRISTEVA, J. (dir.). Práticas e linguagens gestuais. Lisboa: Vega, 1979.

GREIMAS, A. J. Sobre o sentido II: Ensaios Semióticos. Tradução: Dilson Ferreira da Cruz. São Paulo: Edusp/Nankin Editorial, 2014.

GREIMAS, A. J. \& COURTÉS, J. Dicionário de Semiótica. 2a . edição. São Paulo: Contexto, 2012.

GUIRADO, N. C. Um sistema semiótico sincrético: a linguagem cinematográfica. Dissertação de mestrado. São Paulo: Universidade de São Paulo (USP), 2013.

HALL, E. T. The voices of time. In: The Silent Language. Doubleday, 1959.

HÉNAULT, A. História concisa da semiótica. São Paulo: Parábola Editorial, 2006.

HJELMSLEV, L. Prolegômenos a uma teoria da linguagem. Tradução em português: J. Teixeira Coelho Netto. São Paulo: Perspectiva, 2003 [1961].

HOCKETT, C. F. In search of Jove's brow. American Speech, Durham, NC, v.53, n.4, p. 243 313, 1978. 
HORNSTEIN, N. As time goes by. Massachusetts: MIT Press, 1993.

HOY, D. C. The time of our lives. A critical history of temporality. Cambridge, Massachusetts: The Mit Press, 2009.

ILARI, R. A expressão do tempo em português. São Paulo: Contexto, 2001.

JAKOBSON, R. Shifters, verbal categories, and the Russian verb. Selected writings. II Word and language. Paris: Mouton, p. 130-153, 1971.

JAKOBSON, R. Linguística e comunicação. São Paulo: Cultrix, 1977.

JAKOBSON, R. Essais de linguistique générale. I Les fundations Du langage. Paris: Les Éditions de Minuit, 1963.

JAKOBSON, R. Linguística. Poética. Cinema. Roman Jakobson no Brasil. São Paulo: Perspectiva, 1970.

JAKOBSON, R. Essais de linguistique générale. II Rapports internes et externes du langage. Paris: Les Éditions de Minuit, 1973.

JAKOBSON, R. \& POMORSKA. Diálogos. São Paulo: Cultrix, 1985.

JESPERSEN, O. Person. The philosophy of grammar. London: George Allen \& Unwin LTD, p. 212-225, 1924.

JOHNSTON, T.; SCHEMBRI, A. Australian Sign Language. An introduction to sign language linguistics. Cambridge: Cambridge University Press, 2007.

KARNOPP, L. B. Aquisição do Parâmetro Configuração de Mão dos Sinais da LIBRAS: estudo sobre quatro crianças surdas filhas de pais surdos. Dissertação de mestrado. Porto Alegre: Instituto de Letras e Artes da Pontifícia Universidade Católica do Rio Grande do Sul (PUCRS), 1994.

KARNOPP, L. B. Aquisição fonológica na Língua Brasileira de Sinais: estudo longitudinal de uma criança surda. Tese de doutorado. Porto Alegre: Pontifícia Universidade Católica do Rio Grande do Sul (PUCRS), 1999.

KLIMA, E. S.; BELlugI, U. (1979). The signs of language. Cambridge, MA: Harvard University Press.

LABOV, W.; WALETZKY, J. Narrative analysis: oral versions of personal experience. In: MACNEISH, H. (Ed.) Essays on the verbal and visual arts. Seatle, Washington Press, 1967.

LAHUD, M. A propósito da noção de dêixis. São Paulo: Ática, 1979.

LANGACKER, R. W. Foundations of cognitive grammar. Descriptive application. Stanford, CA: Stanford University Press, v. 2, 1991. 
LEITE, T. de A. A segmentação da língua de sinais brasileira (libras): Um estudo linguístico descritivo a partir da conversação espontânea entre surdos. Tese de doutorado. São Paulo: Universidade de São Paulo (USP), 2008a.

LEITE, T. do A. Língua, identidade e educação de surdos. Ponto Urbe [Online], 2, http://pontourbe.revues.org/1912, 2008b.

LIDDELL, S. K. An introduction to relative clauses in ASL. In: Siple, P. (Ed.). Understanding language through Sign Language research. New York: Academic Press, 1978.

LIDDELL, S. K. Real, surrogate, and token space: grammatical consequences in ASL. In: EMMOREY, K.; REILLY, J. (Eds.). Language, gesture and space. Hillsdale, N. J.: Lawrence Erlbaum Associates, p. 19-41, 1995.

LIDDELL, S. K. Grammar, gesture and meaning in American Sign Language. Cambridge: Cambridge University Press, 2003.

LILLO-MARTIN, D. C. Parameter setting: Evidence from use, acquisition, and breakdown in American Sign Language. PH. D. University of California, San Diego, 1986.

LILLO-MARTIN, D. C. Where are all the modality effects?. In: MEIER, R. P.; CORMIER, K.; QUINTO-POZOS, D. (Eds.). Modality and structure in signed and spoken languages. Cambridge: Cambridge University Press, p. 02-22, 2001.

LILLO-MARTIN, D. C.; KLIMA, E. S. Pointing out differences: ASL pronouns in syntactic theory. In: FISCHER, S.; SIPLE, P. (Eds.). Theorical issues in sign language research. Linguistics. Chicago: University of Chicago Press, v. 1, p. 191-210, 1990.

LIN, J-W. Time in a language without tense: the case of chinese. Journal of Semantics. 23 (1), 2006.

LLOSA, M. V. Quem matou Palomino Molero? Rio de Janeiro: Francisco Alves, 1987.

LOPES, I. C; HERNANDES, N. (Orgs.). Semiótica: objetos e práticas. São Paulo: Contexto, 2005.

LYONS, J. Tense, mood and aspect. Introduction to Theoretical Linguistics. Cambridge: Cambridge University Press, p. 304-317. 1968.

LYONS, J. Person-deixis. Semantics. Cambridge: Cambridge University Press, v. 2, p. 636-646, 1979.

MARONEY, E. Aspect in American Sign Language. Ph.D. Linguistics. University of New Mexico, 2004.

MCCLEARY, L.; VIOTTI, E. Transcrição de dados de uma língua sinalizada: Um estudo piloto da transcrição de narrativas na língua de sinais brasileira (LSB). In: LIMA-SALLES, H. (Org.). Bilinguismo dos surdos. Questões linguísticas e educacionais. Goiânia: Cânone Editorial, 2007. 
MCCLEARY, L.; VIOTTI, E. Sign-gesture symbiosis in Brazilian Sign Language narrative. IN: PARRILL, F.; TOBIN, V.; TURNER, M. (Eds.). Meaning, form, and body. CSLI Publications. 2010.

MCCLEARY, L.; VIOTTI, E. Língua e Gesto em línguas sinalizadas. Veredas on-line Atemática, 1, p. 289-304, PPG Linguística/ UFJF, Juiz de Fora, MG, 2011.

MCCLEARY, L.; VIOTTI, E. Espaços integrados e corpos partidos: vozes e perspectivas narrativas em línguas sinalizadas. Scripta, 18 (34), 2014.

MCCLEARY, L.; VIOTTI, E.; LEITE, T. Descrição das línguas sinalizadas: A questão da transcrição dos dados. Alfa 54 (1): 265-289. Acessível em: HTTP://seer.fclar.unesp.br/alfa/article/view/2880, 2010.

MCCLEARY, L. \& LEITE, T. DE A. Turn-taking in Brazilian Sign Language: Evidence from overlap. Journal of Interactional Research in Communication Disorders, 3(2), 2012.

MCNEILL, D. Hand and Mind. Chicago: University of Chicago Press, 1992.

MEIER, R. P. Person deixis in American Sign Language. In: Fischer, S; Siple. P. (Eds.). Theoretical issues in sign language research. Linguistics. Chicago: University of Chicago Press, v. 1, p. 175-190, 1990.

MEIR, I. A cross-modality perspective on verb agreement. Natural Language Linguistic Theory, v. 20, p. 413-450, 2002.

MEIR, I.; SANDLER, W. A language in space: The story of Israeli Sign Language. New York: Lawrence Erlbaum Associates, 2008.

MENDES, R. B. Estar+gerúndio e ter+particípio: aspecto verbal e variação no português. Tese de doutorado. Universidade de São Paulo (USP), 2005.

MINTZ, B. F. Categorías verbales de aspecto y tiempo en la lengua de señas mexicana. In: QUESADA, M.; MALDONADO, R. (Eds.). Dimensiones del aspecto en español. Universidad Nacional Autónoma de México, México, 2005.

MOREIRA, R. L. Uma descrição da dêixis de pessoa na língua de sinais brasileira: Pronomes pessoais e verbos indicadores. Dissertação de mestrado. São Paulo: Universidade de São Paulo (USP) 2007.

MOREIRA, R. L. Uma descrição da dêixis de tempo em narrativas em libras. Projeto de Doutorado. São Paulo: Universidade de São Paulo (USP), 2012.

MOREIRA, R. L (2014). Quem é esse cara? A ilusão enunciativa na canção "Esse cara sou eu”. $\begin{array}{lllllll}\text { Cadernos da Pós-graduação do } & \text { Mackenzie, } & \text { v. } & 1, & 2014\end{array}$ (http://www.mackenzie.br/fileadmin/Pos_Graduacao/Doutorado/Letras/Cadernos/Volum e_1_2014/Quem_e_esse_cara_A_ilusao_enunciativa.pdf

NUNES, B. O tempo na narrativa. São Paulo: Ática, 1995. 
OLIVEIRA, A. C. de; TEIXEIRA, L. (Orgs.). Linguagens na comunicação: desenvolvimentos de semiótica sincrética. São Paulo: Estação das Letras e Cores, 2009.

PADDEN, C. A. Interaction of morphology and syntax in ASL. Garland Outstanding Dissertations in Linguistics, series IV. New York, NY: Garland, 1983.

PEIRCE, C. S. Semiótica e filosofia. Tradução em português: Octammy Silveira da Mota e Leônidas Hegenberg. São Paulo: Cultrix, p. 93-134, 1972.

PIETROFORTE, A. V. Semiótica visual: os percursos do olhar. $3^{\mathrm{a}}$ ed. São Paulo: Contexto, 2012.

PONTES, E. Espaço e tempo na língua portuguesa. Campinas/SP: Pontes, 1992.

PROPP, V. Morfologia do conto. Lisboa: Vega, 1983.

QUADROS, R. M. de. As categorias vazias pronominais: uma análise alternativa com base na língua de sinais brasileira e reflexos no processo de aquisição. Dissertação de mestrado. Porto Alegre: Pontifícia Universidade Católica do Rio Grande do Sul (PUCRS), 1995.

QUADROS, R. M. de. Educação de surdos: a aquisição da linguagem. Porto Alegre: Artes Médicas, 1997.

QUADROS, R. M. de. Phrase structure of Brazilian Sign Language. Tese de doutorado. Porto Alegre: Pontifícia Universidade Católica do Rio Grande do Sul (PUCRS), 1999.

QUADROS, R. M. de. Gramática da língua de sinais brasileira: Os diferentes tipos de verbos e suas repercussões na sintaxe. Revista da ANPOLL, n. 16, p. 289-320, 2004.

QUADROS, R. M. de. Estudos de línguas de sinais: uma entrevista com Ronice Müller de Quadros. ReVEL, vol. 10, n. 19, 2012 [www.revel.inf.br].

REICHENBACH, H. Elements of symbolic logic. New York: MacMillan, 1947.

SACKS, O. Vendo vozes: uma viagem ao mundo dos surdos. São Paulo: Companhia das Letras, 2010.

SAUSSURE, F. Curso de lingüística geral. São Paulo: Cultrix, 1995 [1969].

SEELANDER, A. L. O gesto em dança: descrição da gestualidade em uma narrativa dançada. Dissertação de mestrado. São Paulo: Universidade de São Paulo (USP), 2013.

SILVA, I. A. de. A dêixis de pessoa. Tese de doutorado. São Paulo: Universidade de São Paulo (USP), 1972.

SILVA, O. J. M. A manifestação de Cronos em 35mm: o tempo no cinema. Dissertação de mestrado, São Paulo: Universidade de São Paulo (USP), 2004.

SILVA, O. J. M. A programação temporal no cinema: a representação da ordem dos acontecimentos. Cadernos de Semiótica Aplicada (CASA), vol. 7, n. 2, 2009a. 
SILVA, O. J. M. O observador no desenrolar do processo: a aspectualização qualitative do tempo no discurso cinematográfico. Alfa, 53(2), p. 557-573. São Paulo, 2009b.

SILVA, G. L. de A. Mãos cheias de palavras num corpo que fala: o discurso figurativo do sujeito surdo. Dissertação de mestrado. Vitória - ES: Universidade Federal do Espírito Santos, 2009.

SILVA, J. P. da. Demonstrações em uma narrativa sinalizada em libras. Dissertação de mestrado. São Paulo: Universidade de São Paulo (USP), 2014.

SINTE, A. Expression of time in French Belgian Sign Language. In: MEURANT, L.; SINTE, A., VAN HERREWEGHE, M. Sign Language Research, Uses and Practices: Crossing views on theoretical and applied Sign Language Linguistics. Berlin, Germany: De Gruyter Mouton, 2013.

STOKOE, W. C. Sign language structure: An outline of the visual communication system for the American deaf. Buffalo, NY: Buffalo University, 1960.

STOKOE, W. C. Syntactic dimensionality: Language in four dimensions. Trabalho inédito apresentado à New York Academy of Sciences, 1979.

TATIT, L. Corpo na semiótica e nas artes. In: SILVA, I. (Org.). Corpo e Sentido. A escuta do sensível. São Paulo: Editora Unesp, 1996.

TATIT, L. Análise semiótica através das letras. São Paulo: Ateliê Editorial, 2001.

TATIT, L.. Ilusão enunciativa na canção. Per Musi, n. 29, p. 33-38, Belo Horizonte, 2014.

TATIT, L. \& LOPES, I. Elos de melodia e letra. Análise semiótica de seis canções. São Paulo: Ateliê Editorial, 2008.

TENUTA, A.M. Tempo, modo e aspecto verbal na estruturação do discurso narrativo. Dissertação de mestrado. Belo Horizonte - MG: Universidade Federal de Minas Gerais, 1992.

TENUTA, A. M. de A. Estrutura narrativa e espaços mentais. Belo Horizonte: Faculdade de Letras da UFMG, 2006.

THOMPSON, E. P. O tempo, a disciplina do trabalho e o capitalismo industrial. In: SILVA, T. T. (Ed.). Trabalho, educação e prática social. Porto Alegre: Artes Médicas, 1991.

WILCOX, S. The Iconic mapping of space and time in sign language. Albuquerque, University of New México, [ms], s/d.

WILCOX, S.; WILCOX, P. P. Aprender a ver. Tradução de Tarcísio de Arantes Leite. Rio de Janeiro: Editora Arara Azul, 2005.

WILCOX, S.; XAVIER, A. N. Um quadro teórico para um tratamento unificado das línguas faladas, línguas sinalizadas e gestos. Todas as Letras, v. 15, n. 1, 88-110, 2013. 
VERGAMINI, S. A. A. (org.). Mãos fazendo história. Petrópolis - RJ: Editora Arara Azul, 2003.

VIOTTI, E. Línguas de sinais: desafios para o entendimento da gramática das línguas naturais. Palestra realizada no encontro do FAPS (Fórum de Atualização em Pesquisas Semióticas) do Grupo de Estudos Semióticos (GES-USP) da Universidade de São Paulo (USP). São Paulo, FFLCH / USP, 2005.

VIOTTI, E. Uma ponte entre a linguística teórica e a linguística aplicada: discutindo a questão do bilinguismo dos surdos. Apresentação no VII Congresso da Abralin, Curitiba, 2011.

VIOTTI, E. Apresentação para o Dossiê - Línguas de sinais. Todas as letras U, v. 15, n. 1, 12 14, 2013.

XAVIER, A. N. Descrição fonético-fonológica dos sinais da língua de sinais brasileira. Dissertação de mestrado. São Paulo: Universidade de São Paulo (USP), 2006.

XAVIER, A. N. Uma ou duas mãos? Eis a questão! Um estudo do parâmetro número de mãos na produção de sinais da língua brasileira de sinais (libras). Tese de doutorado. Campinas- SP: Universidade Estadual de Campinas (Unicamp), 2014.

XAVIER, A. N.; BARBOSA, P. "Com quantas mãos se faz um sinal? Um estudo do parâmetro número de mãos na produção de sinais da língua brasileira de sinais (libras)". Todas as Letras U, v. 15, n. 1, 111-128, 2013.

ZILBERBERG, C. Razão e poética do sentido. São Paulo: EDUSP, 2006.

ZILBERBERG, C. Elementos de semiótica tensiva. Tradução: Waldir Beividas, Ivã Carlos Lopes e Luiz Tatit. São Paulo: Ateliê Editorial, 2012.

ZILBERBERG, C. Du tempo en peinture. Actes Semiotiques, n. 118, 01-14. Disponível em http://epublications.unilim.fr/revues/as/5508, 2015.

ZWAAN, R. A. Time in language, situations models, and mental simulations. Language Learning, 58: 13-26, 2008. 
ANEXOS 


\section{I) RELATÓRIO COM A TRANSCRIÇÃO DO TEXTO "HISTÓRIA DO GIBI 1"}

\begin{tabular}{|c|c|c|}
\hline 1 & IU & Sim \\
\hline 2 & IU & $\begin{array}{l}\text { [Você] conhece [os] quadrinhos visuais [que] contam história[s] [da] turma } \\
\text { da Mônica? }\end{array}$ \\
\hline 3 & $\mathrm{IU}$ & [Não é?] \\
\hline 4 & $\mathrm{IU}$ & Agora [vou contar a história [cujo] título [é:] "como parar de chorar" \\
\hline 5 & $\mathrm{IU}$ & [Qual é o] jeito [de] ajudar? [O título é:] Como? \\
\hline 6 & IU & Cebolinha, ele [estava] andando, andando... \\
\hline 7 & IU & [Cebolinha estava] anda[ndo e, de repente,] viu Magali chora[ndo muito] \\
\hline 8 & IU & [Que] estranho! \\
\hline 9 & $\mathrm{IU}$ & [Eles se] encontraram [e Cebolinha] chamou [a Magali e perguntou a ela:] \\
\hline 10 & $\mathrm{IU}$ & [O] que [que] aconteceu [que você está] chorando? \\
\hline 11 & IU & [Magali] chama [o Cebolinha e diz: tem uma] árvore. \\
\hline 12 & $\mathrm{IU}$ & [tem] maçãs [na] árvore [mas] eu não consigo pegá-[lãs]. \\
\hline 13 & $\mathrm{IU}$ & [Eu estou com] fome, [e] eu [estou] triste. \\
\hline 14 & IU & [Ah...] espere! Eu [vou te] ajudar! \\
\hline 15 & $\mathrm{IU}$ & [Tinha] uma árvore [cheia de/com] maçã. \\
\hline 16 & $\mathrm{IU}$ & Cebolinha [pensa: ["vou] tentar ..." \\
\hline 17 & IU & [Ele] andou [até a árvore], subiu, subiu, subiu [ e] conseguiu pegar [a maçã]. \\
\hline 18 & IU & [Por] azar, [o] galho quebrou [e o Cebolinha] caiu. \\
\hline 19 & IU & [A] maçã [ficou] inteira. [Que] sorte! [A Magali diz:] "Obrigada"! \\
\hline 20 & $\mathrm{IU}$ & [Cebolinha] entrega [a maçã para a Magali] \\
\hline 21 & IU & Magali [fica muito] feliz com a maçã e a] come. \\
\hline 22 & IU & [Cebolinha coloca as mãos nas costas e pensa: "Que] dor!". \\
\hline 23 & $\mathrm{IU}$ & [Cebolinha] continuou andando [e de repente] viu [o] Cascão chorando. \\
\hline 24 & IU & [Cebolinha] chama [o] Cascão [e diz:] \\
\hline 25 & IU & $\begin{array}{l}\text { [O que foi, Cascão?]. [O] que [que] aconteceu? [Você está] chorando, [está] triste. Aconteceu [o] } \\
\text { quê? }\end{array}$ \\
\hline 26 & IU & [Cascão, chateado, diz:] eu [estava] brincando, [jogando] futebol, [com] a bola. \\
\hline 27 & IU & $\begin{array}{l}\text { [Eu estava jogando] futebol],quando, de repente, a] bola foi [parar no meio] água [do rio] e } \\
\text { afundou... }\end{array}$ \\
\hline 28 & IU & [Eu fiquei] chatead@. Espere! Eu [vou te] ajudar. \\
\hline 29 & $\mathrm{IU}$ & [Tinha uma] área [com] água [e a] bola [estava lá] boiando. \\
\hline 30 & IU & $\begin{array}{l}\text { Cebolinha tentou [e] pulou, pulou, pulou (as) pedra(s) [até a bola, mas, de repente, tropeçou,] caiu } \\
\text { [e afundou]. }\end{array}$ \\
\hline 31 & IU & $\begin{array}{l}\text { [Cebolinha quase se afogou, mas] pegou [a bola], nadou [com ela até a margem do lago, e saiu da } \\
\text { água] }\end{array}$ \\
\hline 32 & IU & [Cebolinha diz:] Consegui! [Cebolinha estava todo] ensopado. \\
\hline 33 & IU & [Cebolinha diz:] Consegui [pegar a] bola. \\
\hline 34 & $\mathrm{IU}$ & [Cebolinha] entregou [a] bola [para o Cascão]. \\
\hline 35 & $\mathrm{IU}$ & [O] Cascão [agradece] feliz. [O Cascão] foi embora brincar... \\
\hline 36 & $\mathrm{IU}$ & [e o Cebolinha ficou] cansado. \\
\hline 37 & IU & Ele [continuou] andando [e] viu [uma] mulher [de cabelo comprido]: Marina. \\
\hline 38 & IU & $\begin{array}{l}\text { [Cebolinha] chama [Marina e lhe pergunta: o] que aconteceu [que está] chorando, triste? [O que] } \\
\text { aconteceu? }\end{array}$ \\
\hline 39 & $\mathrm{IU}$ & Eu [estou] triste, porque [estava] pintando. \\
\hline 40 & IU & $\begin{array}{l}\text { Eu [estava] pintando, [feliz], [quando, de repente, começou a] ventar [forte, e a minha] pintura } \\
\text { [saiu] voando [e foi parar em cima do] telhado [de uma] casa. }\end{array}$ \\
\hline 41 & $\mathrm{IU}$ & [Olha] lá [minha pintura, lá em cima, eu] não acredito [nisso]. Tem [que] deixar [lá]. \\
\hline 42 & IU & [A] casa [estava cercada por um] muro [e, ao lado da casa, havia um] cachorro [bravo] latindo. \\
\hline 43 & IU & Como [pegar? Oh...como? Por isso, estou] chorando, triste]. \\
\hline
\end{tabular}




\begin{tabular}{|c|c|c|}
\hline 44 & IU & Cebolinha, [então, disse a Marina:] \\
\hline 45 & IU & Ah! Eu [vou] pegar. Espere! Eu [vou] tentar! [Como?] Espere! [Eu vou] tentar! \\
\hline 46 & $\mathrm{IU}$ & $\begin{array}{l}\text { [Cebolinha] caminhou [até o] muro, escalou [a parede e chegou no topo]. Olhou [para baixo e viu } \\
\text { o] cachorro, [do outro lado do muro, bravo] latindo. [Sentiu medo]. }\end{array}$ \\
\hline 47 & IU & $\begin{array}{l}\text { [Cebolinha olhou para o lado e] viu [que] tinha [uma] árvore [ali, perto dele. Ele, então, pegou } \\
\text { impulso e] saltou [para um de seus] galhos [e ficou] pendurado [como um] passarinho [no] galho, } \\
\text { [com medo de cair]. }\end{array}$ \\
\hline 48 & IU & [No] galho, [ele toma impulso novamente e] salta [para o] telhado [da] casa. \\
\hline 49 & IU & [Em cima do telhado, Cebolinha diz:Ufa!] Não acredito [que] consegui pegar. \\
\hline 50 & IU & $\begin{array}{l}\text { [Cebolinha viu o] desenho [no] telhado [e o] pegou. [De novo, Cebolinha] saltou, [do] telhado } \\
\text { [para a árvore]. [Ficou desesperado]. Conseguiu [se] pendurar [no] galho [da] árvore, saltou [e } \\
\text { acabou] caindo [no chão. Mas] conseguiu sobreviver. }\end{array}$ \\
\hline 51 & IU & [Cebolinha se levanta, com] dor. \\
\hline 52 & IU & $\begin{array}{l}\text { [E a menina] Marina, [feliz, diz:] [Você] conseguiu! [Ela] pega [seu desenho e agradece o } \\
\text { Cebolinha:] Obrigada! }\end{array}$ \\
\hline 53 & IU & [Ela vai embora,] caminhando, [feliz]. \\
\hline 54 & IU & $\begin{array}{l}\text { [Cebolinha se recupera da queda, ainda com] dor. Não [foi] fácil [tudo que passou]. [Mas] ele } \\
\text { [continua] caminhando. }\end{array}$ \\
\hline 55 & IU & [Cebolinha estranha o que vê e diz:] Nossa! \\
\hline 56 & IU & Como? [O que está] acontecendo? Como? [Tinha uma] casa. \\
\hline 57 & IU & [Tinha um] muro [que cercava toda a] casa. \\
\hline 58 & IU & $\begin{array}{l}\text { [Tinha um buraco grande com] água, [no quintal, e um] cachorro, [do outro lado, ] dormindo, [e } \\
\text { ali estava] ele. }\end{array}$ \\
\hline 59 & IU & Ele é...[Qual é o] nome dele? \\
\hline 60 & IU & [Tinha a] árvore [e o] coelho [da] Mônica [estava embaixo dela]. \\
\hline 61 & IU & $\begin{array}{l}\text { Eu [pegar esse coelho?] Eu? Não posso Imaginar [a] Mônica! Ela [vendo] eu pegar [o coelho. } \\
\text { Ah...não...] AFFFFF! }\end{array}$ \\
\hline 62 & IU & Fim! \\
\hline
\end{tabular}


II) LEVANTAMENTO DOS SINAIS DICIONARIZADOS QUE INDICAM TEMPO

\begin{tabular}{|c|c|c|}
\hline & Nome dos sinais & $\begin{array}{l}\text { Número da página no } \\
\text { dicionário de Capovilla } \\
\text { \& Raphael (2001) }\end{array}$ \\
\hline 1 & ABRIL & 140 \\
\hline 2 & ACORDAR (1) & 150 \\
\hline 3 & ACORDAR (2) & 151 \\
\hline 4 & ACOSTUMAR & 151 \\
\hline 5 & ADORMECER & 158 \\
\hline 6 & AGENDAR & 164 \\
\hline 7 & AGORA (1) & 165 \\
\hline 8 & AGORA (2) & 165 \\
\hline 9 & AGOSTO & 166 \\
\hline 10 & AINDA & 169 \\
\hline 11 & AINDA NÃO & 169 \\
\hline 12 & ALÉM & 173 \\
\hline 13 & AMANHÃ & 183 \\
\hline 14 & ANO & 200 \\
\hline 15 & ANO NOVO & 200 \\
\hline 16 & ANO PASSADO & 200 \\
\hline 17 & ANO QUE VEM (1) & 201 \\
\hline 18 & ANO QUE VEM (2) & 201 \\
\hline 19 & ANTECIPAR & 202 \\
\hline 20 & ANTEONTEM & 203 \\
\hline 21 & ANTES & 203 \\
\hline 22 & ANTIGO (A) & 203 \\
\hline 23 & AOS POUCOS & 206 \\
\hline 24 & ATÉ (1) & 239 \\
\hline 25 & ATÉ (2) & 239 \\
\hline 26 & ATÉ LOGO! & 239 \\
\hline 27 & ATRÁS (2) & 243 \\
\hline 28 & BASTA! (1) & 278 \\
\hline 29 & BASTA! (2) & 279 \\
\hline 30 & BASTA DE VEZ! & 279 \\
\hline 31 & CALENDÁRIO & 343 \\
\hline 32 & CHEGA! (1) & 397 \\
\hline 33 & CHEGA! (2) & 397 \\
\hline 34 & CHEGA! (3) & 397 \\
\hline 35 & COMEÇAR (1) & 433 \\
\hline 36 & COMEÇAR (2) & 433 \\
\hline 37 & CONCLUIR & 442 \\
\hline 38 & CONTINUAR (1) & 457 \\
\hline 39 & CRESCER (1) & 481 \\
\hline 40 & CRESCER (2) & 481 \\
\hline 41 & DE NOVO & 497 \\
\hline 42 & DEMORAR & 511 \\
\hline 43 & DEPOIS (1) & 514 \\
\hline 44 & DEPOIS (2) & 514 \\
\hline 45 & DEPRESSA & 515 \\
\hline 46 & DESPERTAR & 531 \\
\hline 47 & DEZEMBRO & 538 \\
\hline 48 & DIA (1) & 539 \\
\hline 49 & DIA (2) & 540 \\
\hline
\end{tabular}




\begin{tabular}{|c|c|c|}
\hline 50 & DIA (3) & 540 \\
\hline 51 & DIA TODO & 540 \\
\hline 52 & DIARIAMENTE & 542 \\
\hline 53 & DOMINGO & 562 \\
\hline 54 & DURANTE & 566 \\
\hline 55 & ETERNO (A) & 631 \\
\hline 56 & EXEMPLO & 636 \\
\hline 57 & FERIADO & 661 \\
\hline 58 & FÉRIAS & 661 \\
\hline 59 & FEVEREIRO (1) & 663 \\
\hline 60 & FEVEREIRO (2) & 664 \\
\hline 61 & FIM & 670 \\
\hline 62 & FIM DE SEMANA (1) & 670 \\
\hline 63 & FIM DE SEMANA (2) & 671 \\
\hline 64 & FINDAR & 671 \\
\hline 65 & FUTURO (A) & 697 \\
\hline 66 & HÁ TEMPOS & 729 \\
\hline 67 & HOJE (1) & 735 \\
\hline 68 & HOJE (2) & 736 \\
\hline 69 & HORA & 738 \\
\hline 70 & HORAS E HORAS & 738 \\
\hline 71 & IDADE & 741 \\
\hline 72 & IMAGINAR & 746 \\
\hline 73 & INVERNO & 767 \\
\hline 74 & IR & 768 \\
\hline 75 & JÁ & 773 \\
\hline 76 & JÁ FOI! & 773 \\
\hline 77 & JANEIRO & 775 \\
\hline 78 & JULHO & 789 \\
\hline 79 & JUNHO & 790 \\
\hline 80 & LEMBRAR & 807 \\
\hline 81 & LONGO (A) & 827 \\
\hline 82 & MAIO & 857 \\
\hline 83 & MAIS TARDE & 859 \\
\hline 84 & MANHÃ & 865 \\
\hline 85 & MARÇO (1) & 870 \\
\hline 86 & MARÇO (2) & 871 \\
\hline 87 & MEIA HORA & 884 \\
\hline 88 & MEIA-NOITE (1) & 884 \\
\hline 89 & MEIA-NOITE (2) & 884 \\
\hline 90 & MEIO-DIA & 885 \\
\hline 91 & MÊS & 893 \\
\hline 92 & NOITE (1) & 949 \\
\hline 93 & NOITE (2) & 949 \\
\hline 94 & NOVEMBRO & 954 \\
\hline 95 & NUNCA (1) & 964 \\
\hline 96 & NUNCA (2) & 964 \\
\hline 97 & NUNCA MAIS & 965 \\
\hline 98 & ONTEM & 980 \\
\hline 99 & OUTONO & 987 \\
\hline 100 & OUTRA VEZ & 987 \\
\hline 101 & OUTUBRO & 988 \\
\hline 102 & PARA TRÁS & 1007 \\
\hline 103 & PASSADO (A) & 1015 \\
\hline 104 & PERDER A HORA & 1030 \\
\hline 105 & PERDER TEMPO & 1030 \\
\hline
\end{tabular}




\begin{tabular}{|c|c|c|}
\hline 106 & PERÍODO & 1034 \\
\hline 107 & PERPÉTUO (A) & 1036 \\
\hline 108 & PONTUAL & 1059 \\
\hline 109 & PONTUALIDADE & 1060 \\
\hline 110 & PÔR DO SOL & 1061 \\
\hline 111 & POSTERGAR & 1068 \\
\hline 112 & POSTERIOR & 1068 \\
\hline 113 & POUCOS MINUTOS & 1069 \\
\hline 114 & PRAZO & 1071 \\
\hline 115 & PRESENTE & 1077 \\
\hline 116 & PRESTAÇÃO & 1078 \\
\hline 117 & PRIMAVERA & 1080 \\
\hline 118 & PRIMEIRA VEZ & 1081 \\
\hline 119 & PRIMEIRO (1) & 1081 \\
\hline 120 & PROLONGADO (A) & 1087 \\
\hline 121 & PROSSEGUIR & 1089 \\
\hline 122 & PRÓXIMO (A) (2) & 1092 \\
\hline 123 & QUANDO? (NO FUTURO) & 1100 \\
\hline 124 & QUANDO (NO PASSADO) & 1100 \\
\hline 125 & QUARTA-FEIRA (1) & 1101 \\
\hline 126 & QUARTA-FEIRA (2) & 1101 \\
\hline 127 & QUE HORAS SÃO? & 1104 \\
\hline 128 & QUINTA-FEIRA (1) & 1108 \\
\hline 129 & QUINTA-FEIRA (2) & 1108 \\
\hline 130 & RÁPIDO (A) & 1115 \\
\hline 131 & SÁBADO & 1157 \\
\hline 132 & SE & 1171 \\
\hline 133 & SEGUINTE & 1175 \\
\hline 134 & SEGUNDA-FEIRA (1) & 1176 \\
\hline 135 & SEGUNDA-FEIRA (2) & 1176 \\
\hline 136 & SEGUNDA VEZ & 1176 \\
\hline 137 & SEMANA & 1180 \\
\hline 138 & SEMESTRE & 1181 \\
\hline 139 & SEMPRE & 1181 \\
\hline 140 & SETEMBRO & 1194 \\
\hline 141 & SEXTA-FEIRA (1) & 1195 \\
\hline 142 & SEXTA-FEIRA (2) & 1196 \\
\hline 143 & TARDE & 1232 \\
\hline 144 & TEMPO & 1240 \\
\hline 145 & TERÇA-FEIRA (1) & 1243 \\
\hline 146 & TERÇA-FEIRA (2) & 1244 \\
\hline 147 & TODA MANHÃ & 1255 \\
\hline 148 & TODA TARDE & 1255 \\
\hline 149 & TODA VEZ & 1256 \\
\hline 150 & TODO DIA & 1256 \\
\hline 151 & TRANSFERIR (2) & 1266 \\
\hline 152 & TRÁS & 1269 \\
\hline 153 & ÚLTIMO (A) (1) & 1281 \\
\hline 154 & VÁRIAS VEZES & 1300 \\
\hline 155 & VERÃO & 1308 \\
\hline
\end{tabular}




\section{III) DVD COM OS TEXTOS, OS EXEMPLOS DA TESE E A TRANSCRIÇÃO NO ELAN}

O DVD que você está recebendo contém os seguintes arquivos:

1) Os vídeos dos seis textos analisados "História do Gibi 1", "História do Gibi 2", "O amor é surdo", "Minha Vida", "Sonhos” e "Metáfora - O escorpião e a tartaruga";

2) Os vídeos com outros textos em libras e também textos em português que serviram de exemplo no trabalho: "Imaginação", "Dúvida", "Sonho com um carro novo", "Explicação"; “Aula de História"; "História do Gibi em Português"; "Show do Roberto Carlos", e os vídeos com o comercial do "carro Fox" e o do "Panetone Bauducco";

3) A transcrição do texto "História do Gibi 1" no ELAN e o arquivo auxiliar da transcrição do ELAN (Transcrição do texto história do gibi 1.pfsx), que não precisa ser aberto, mas é necessário para que o arquivo principal da transcrição seja acessado

4) Os vídeoclipes dos exemplos citados no trabalho: trechos do vídeo dos textos representados pelas figuras que aparecem na tese.

Todos esses arquivos encontram-se em uma única pasta "Arquivos - DVD que acompanha a tese de doutorado - Renata Lúcia Moreira”, no DVD afixado na próxima página. Dentro dessa pasta, há 4 outras, nomeadas, respectivamente, "Corpus da tese", "Outros textos analisados", "Transcrição no ELAN" e "Clipes dos Exemplos".

Para assistir às filmagens, sem transcrição, basta clicar nos arquivos denominados Vídeo de História do gibi 1, Vídeo de História do gibi 2, Vídeo de $\mathbf{O}$ amor é surdo, Vídeo de Minha Vida, Vídeo de Sonhos, Vídeo de Metáfora - O escorpião e a tartaruga, Vídeo de Imaginação, Vídeo de Dúvida, Vídeo de Sonho com um carro novo, Vídeo de Explicação, Vídeo de Aula de História e Vídeo de Exemplos - Neiva.

Para ver os trechos dos textos apresentados no trabalho, basta clicar no videoclipe referente à figura que aparece na tese. No caso das figuras 12 a 15, por exemplo, você encontrará o dado no videoclipe 0 ; a figura 16, no videoclipe 1 , e, assim, sucessivamente.

Para acompanhar a "História do Gibi 1", é preciso clicar apenas no arquivo denominado "Transcrição do texto história do gibi 1. eaf", selecionar o vídeo, que está na mesma pasta, e baixar, gratuitamente, da Internet uma versão atualizada do programa do ELAN (sítio: http://www.mpi.nl/tools/elan.html). 


\begin{tabular}{|c|}
\hline DVD que acompanha a tese \\
\hline Um Olhar da Semiótica para os Discursos em Libras: \\
Descrição do Tempo \\
\hline \\
\hline
\end{tabular}

